\title{
Organisation of the thesaurus
}

This thesaurus presents Vurës words organised according to semantic categories. This means that the words are grouped together according to their meaning, rather than alphabetically as in the main dictionary and finderlists. The structure of the thesaurus is based on that of Tonya Stebbins' Mali (Baining) Dictionary (2012). It is important to note that there are many different ways in which the words of a language could be grouped together on the basis of meaning, and the categories that are distinguished here reflect my interpretation based on my knowledge of Vurës language and culture. The categories do not reflect a particular Vurës interpretation of how words should be grouped together. There is no doubt that Vurës speakers will agree with some of my categorisations, but not all. Mali is a language spoken in Papua New Guinea, which like Vanuatu is a Melanesian country, and there are thus some sociocultural similarities between the two language communities. Both languages are spoken in similar tropical island environments by communities of subsistence farmers who place an emphasis on interaction with and use of the marine and rainforest environments. I therefore found that, for the most part, the categories distinguished by Stebbins for Mali reflect categories that are appropriate for Vurës. I added and removed some categories, partly on the basis of biases in the inclusions in the Vurës data, and partly on my interpretation of the data.

The primary motivation for including this type of thesaurus is so that it can be used to support teaching of literacy skills and cultural knowledge within the community. Teachers and parents are encouraged to use this section of the dictionary to focus on reinforcing traditional knowledge, particularly with young community members. It is for these users that many photos are included, so that a topic can be chosen, such as fish, plants or weaving, and Vurës people can practice learning the words, spelling and meanings of local concepts.

The categories that the thesaurus is organised into are listed below. Note that the thesaurus only includes the Vurës word, English and Bislama and meanings, and scientific name where relevant. Any user who would like more information for a particular word, such as part of speech or an example sentence, should check the word in the main dictionary for that information. Note also that if a word has more than one sense, then only the sense(s) relevant for the particular semantic category are included for an entry. Thus a word might be included under one heading for one sense, but under a different heading for a different sense. 


\section{Contents of Thesaurus}

\section{The natural world}

A Landscape, country and water

A0 General

A1 Topographical features (valley, hill, river, road)

A2 Celestial features (moon, stars)

A3 Water

A3.0 General (drown, splash, wet)

A3.1 Precipitation (hail, mist, dew)

A3.2 Water sources (springs, puddles, lakes)

A3.3 The ocean (waves, tides)

A4 Geological, other substances (sand, plastic, charcoal)

$B$ Weather and cyclic time

B1 Meteorological conditions (wind, cloud, thunder)

B2 Cyclical time

B2.1 Diurnal cycle (early morning, evening)

B2.2 Lunar cycle (new moon, high moon)

B2.3 Seasonal cycle (seasons, months, holidays)

B2.4 Weekly cycle (names of days)

B3 Geological events (volcanic eruption, earthquake)

C Spatial relations

C0 General

C1 Absolute direction (landward, seaward)

C2 Demonstratives (this, that over there)

C3 Pronouns

D Plants

D0 General (thorn, twig, leaf, bark)
D1 Trees and palms (rosewood, bush palm, orange tree)

D1.1 Coconuts

D1.2 Breadfruit

D1.3 Bananas

D2 Bushes, shrubs

D3 Grasses, bamboo, vines

D4 Tubers and roots

D4.1 Taro

D4.2 Yam

D4.3 Cassava

D4.4 Sweet potato

D5 Miscellaneous plants (seaweed, moss, mushrooms)

E Fauna

E0 General

E1 Mammals

E2 Birds

E3 Reptiles

E4 Water creatures

E4.0 Large sea creatures (sharks, dolphins)

E4.1 Fish

E4.2 Eels

E4.3 Prawns and crayfish

E4.4 Shell fish (oysters, shells)

E4.5 All other sea and shore life (sea cucumber, jellyfish)

E5 Crabs and hermit crabs

E6 Insects, other land arthropods, grubs

F $\quad$ Physical properties

F0 General

F1 Appearance

F1.1 Visibility and colour

F1.2 Size, shape, weight, pattern

F2 Temperature, texture 
F3 Sounds - their types and qualities

F4 Tastes and smells (sour, bitter, sweet, stink)

F5 Value (precious, worthless)
$G \quad$ Quantification

G1 Quantity (lots, another of the same type, nothing)

G2 Numerals

\section{Humans, human qualities}

H Human classification

H0 General (names, to name someone)

H1 Spirits and devils

H2 Peoples and language groups

H3 People by age, development, life cycle

H3.0 General (adolescent, infant)

H3.1 Male (young boy, adolescent male)

H3.2 Female (young girl, adolescent female)

H4 Roles and status terms

H5 Types of people not related to status/profession

H6 Address terms

I Human qualities and emotions

I1 Personality and moral evaluations (funny, talkative)

I2 Skill, ability, power (strong, courageous, skilled)

I3 Feelings and emotions (homesickness, jealous)

J Body parts and products (animal and human)

J0 General (head, body, egg)

J1 Internal organs (heart, stomach)

J2 Body products (urine, earwax, saliva)

J3 Extension of body (soul, voice, scar)

K Body states and functions

K1 Physiological reactions (breath, suck, cry, lay eggs)

K2 Body states
K2.1 Temporary (sleep, tired, thirsty, pregnant, bleed)

K2.2 Permanent (blind, deaf)

K3 Sickness, death, disease, injury (unconscious, vomit)

$L \quad$ Stance and motion

L1 Stance, position

L1.0 Stance, position - general (rest, crouch, wait)

L1.1 Stance, position - vertical axis (stand)

L1.2 Stance, position horizontal axis (sit, lie down)

L2 Movement

L2.0 Movement - general (arrive, fly, paddle, chase)

L2.1 Movement - vertical axis (walk, up, climb, dive)

L2.2 Movement - horizontal axis (roll, go across)

L3 Open and close

L3.1 Open (hole, gap, orifice, expose, empty)

L3.2 Close (block, obstruct, finish, switch off, fill)

L4 Exist (be, be lost)

L5 Do (attempt, succeed, make)

L6 Change of state (become)

$M$ Artefacts, material culture and manufactured things

M1 Tools, weapons, belongings

M2 Built environment

M2.0 General (build a house, housework, fence)

M2.1 Parts of a building (house posts, doorway)

M2.2 Furniture 
M3 Clothes, materials and decorations (coat, headdress)

M4 Weaving, woven goods (mat, basket, pandanus)

M5 Nautical (canoe, paddle, sail, anchor)
M6 Transfer of goods (sell, trade, steal)

M7 Vehicles (car, truck, motorcycle, aeroplane)

\section{Human interrelating, humans socially}

$N$ Kinship

N1 Kin terms

O Marriage, sex, nurturing

O1 Marriage and sexual relations

O2 Pregnancy and childbirth (birth, stages of pregnancy)

O3 Rearing babies and children (adoption, look after)

$P \quad$ Speaking, communication

and sounds

P1 Speaking (call out, ask, stutter, explain)

P2 Interjections, imperatives, function words

P2.1 Functional affixes and particles

P2.2 Interjections

P2.3 Conjunctions

P2.4 Subordinators

P2.5 Articles

P2.6 Discourse markers

P3 Negations, assertions, possibility (perhaps, true, no)

P4 Non-verbal communication (write, sign language)

P5 Sounds (dog growl, whistle, clapping, onomatopoeia)

Q Social interaction, relationships

and behaviour

Q0 General (behave, warn someone of trouble)

Q1 Fighting (enemy, get revenge)

Q2 Verbal quarrelling (provoke, ridicule, tease, annoy)

Q3 Making peace, maintaining social harmony
Q4 Games, entertainment, laughter, joking (play)

Q5 Being affected (being helped)

Q6 Permission and prohibition

Q7 Community 


\section{Human interaction with the natural world}

$R$ Religion, ceremony, law and the supernatural

R0 General

R1 Law, sacred places, legends

R2 Ceremony and rituals

R2.1 Ceremonial objects

R2.2 Ceremonies and rituals

R3 Death and mourning

R4 Taboos, strictures and secret knowledge

R5 Healing and medicine

R6 Singing and dancing

R7 Feasting

R8 Christianity

$S \quad$ Hunting, fishing, farming

S1 Hunting

S2 Fishing

S3 Farming and propagation (clearing land, planting)

$T \quad$ Fire and cooking

T1 Fire (cooking fire, matches, burn, smoke)

T2 Food preparation, cooking, distribution, eating (ripe)

$U$ Human uses of natural resources

U1 Food (meat, berries, bread)

U2 Narcotics (alcohol, tobacco)

$V \quad$ Thinking, perception and attention

V1 Sense and perception

V1.1 Seeing (look out, inspect, search)

V1.2 Hearing (listen)

V1.3 Tasting and smelling (try, taste)

V1.4 Physical sensations (feel)

V2 Cognition

V2.1 Mental states (be calm, be delirious)

V2.2 Mental processes and experiences (think, dream)

V2.3 Knowledge and learning (try, graduate)
W Handling and physical transfer

W0 General

W1 Taking, touching, obtaining (snatch, receive, put on)

W2 Holding, carrying, moving something around (lead)

W3 Letting go, giving, leaving be (pour, transfer, spread)

$X \quad$ Impact and surface contact

X0 General (split apart, throw, rip, break, dismantle)

X1 With an instrument (spear, mark, chop)

$\mathrm{X} 2$ Due to pressure (grind, snap, twist, burst)

X3 Sticking, tying, untying (tie up, cover)

X4 Surface contact (rub, peel, scrape, wipe)

$Y$ Speed, manner and relative time

Y0 General (how, like this, manner)

Y1 Speed and manner (fast, carefully, fiercely)

Y2 Relative time and duration (when, previously, new)

Y3 Serialisation (before doing something else, last)

Y4 Degree 


\section{A Landscape, country and water}

\section{AO General}

\section{maram world wol \\ masawre $2 \cdot$ place $~$ ples \\ $\tan _{1} \mathbf{1} \cdot$ earth, soil $\sim$ graon $\mathbf{2} \cdot$ ground $\sim$ graon $\mathbf{3} \cdot$ land $\sim$ graon \\ tönö place $\sim$ ples \\ vene place, owned area of land, place belonging to person or community ples, olsem ples blong man, ples we ol pipol ol i stap long hem \\ vanan her/his/its place $\sim$ ples blong hem \\ vënëk my place ples blong mi}

\section{A1 Topographical features}

bēn lo brackish water, spring water that comes up by the sea and thus is slightly salty but drinkable wota we i spring aot long solwota, yu save dring be i sol smol

bōak 1・ mud sofmad

bōrōt shore, sea shore, strip of sand or land close to the sea $\sim$ so, sanbij o eria we i klosap long solwota

dō cliff klif

gawuw valley $\sim$ vali

geret mountain, high hill maonten, tolfala hil

gersal $1 \cdot$ path, road $\sim \operatorname{rod}$

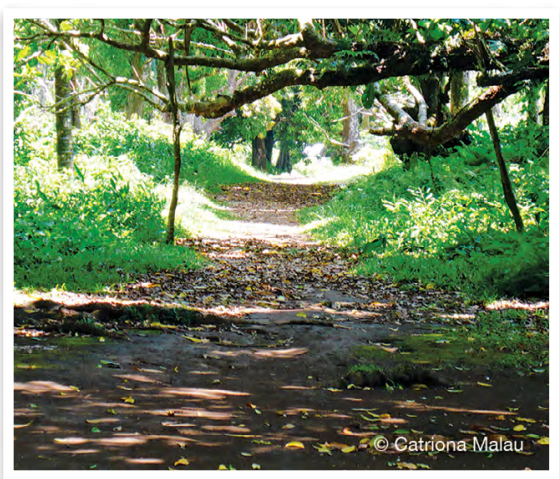

gersal $\sim$ path, road gersal liwō road, main road suitable for vehicles $\sim$ rod, men rod gersalan her/his/its path rod blong hem

gersëlëk my path rod blong mi

kalkal hill, slope of hill hil

lam deep water, deep freshwater pool, deep sea $\sim$ dip wota, dip solwota, dip ples

butölam very deep sea solwota $i$ dip olgeta

vētitnē lam deep sea between islands medel si bitwin tu aelan

le $\overline{\mathbf{e}}_{1}$ cave $\sim$ kef

lie hole hol

lie giav crab hole hol blong krab

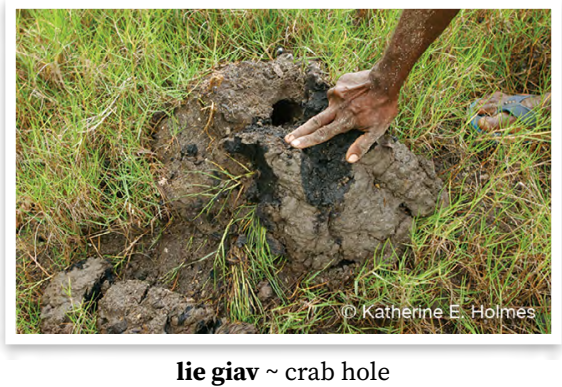

lo ${ }_{1}$ seashore, seaside, area by sea, but not including sea itself solwota, eria klosap long solwota

met area of reef close to shore that is covered during high tide but exposed during low tide $\sim$ rif, ples we solwota mo rif i stap tugeta mo man i save wokabaot long hem mo yusum blong fising

met siag tide is neither high nor low solwota i stap semak nomo, i no save drae mo i no save kam so.

met sörlav time when there is a very high high tide $\sim$ taem we solwota $i$ kam so we i bitim mak blong evri dei long manis 
mësu met ōrōr extreme low tide, which enables reef gleaning of species that would normally not be accessible $\sim$ taem solwota $i$ drae bigwan, mo i minim se yu save karem sam mit we mos taem i stap long dip ples

met mōo ōr low tide, tide going out solwota i drae

mete $1 \overline{0} \mathbf{1} \cdot$ east, place where sun rises $\sim$ ples we san i kam antap 2 • expression used to refer to Sola by people in Vurës, as Sola is towards the east, where sun rises $\sim$ wan wei blong talemaot Sola, from i stap long is, long ples we san i kam antap metesa anchorage, harbour, landing place $\sim$ pasis

möt 1 - bush bus 2 - overgrown, overgrown bushy area of land $\sim$ bus, eria we ol i no klinim gud

möt luwō forest fores, bigfala bus möt vandam̄eg isolated location, interior of island $\sim$ medel bus

nögö lō east, place where sun rises ples we san i kam antap

nenere garden $\sim$ garen

nere ${ }_{2} \mathbf{3}$ point of land $\sim$ poen

nere on stretch of beach where the sand meets the sea ples we sanbij i kasem solwota

nusu $3 \cdot$ point of land $\sim$ poen

ōn $\mathbf{1} \cdot$ sand $\sim$ sanbij $\mathbf{2}$ beach $\sim$ sanbij on wöt place where there is sand and surfable waves $~$ ples we $\mathrm{i}$ gat wef

plantesen plantation plantesen

qarörö hole hol

qereñ bè watercourse, creek gully, place where there is a creek, including creek and edge around it $\sim$ hol blong wota

qereñ ōlōl cave, hole in reef or pool that has special significance, where people go to pray, give money and ask the spirits for something that they want, or to appease and ask forgiveness from the spirits if they have done something wrong against them tabu hol long kef, long rif o long wota we ol man ol i go long hem blong prea long ol speret from wan samting o talem sori from wan samting we yu bin mekem

raras shallow, shallow place $\sim$ salo, ples we wota i no dip

rat flat place, area of land flat ples

rōwnölō east, place where sun rises

is, ples we san i kam antap

sere plen airfield $\sim$ epot

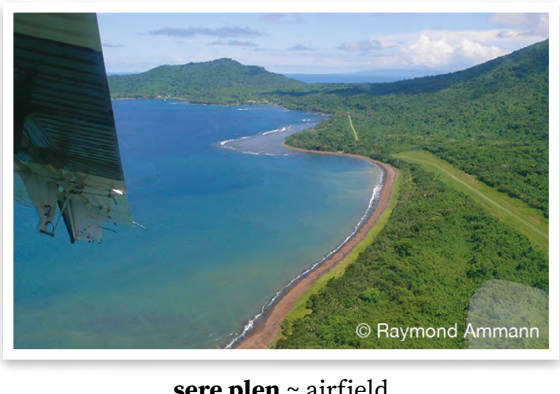

sëkër reef, coral, refers both to an area of reef and to coral heads that comprise the reef $\sim$ rif

$\tan _{1} \mathbf{1} \cdot$ earth, soil $\sim$ graon $2 \cdot$ ground graon $\mathbf{3} \cdot$ land $\sim$ graon

tes lake, large body of water $\sim$ bigfala wota, lek

tique garden $\sim$ garen

tōw hill, mountain hil, maonten

tulnö lō west, place where sun sets wes, ples we san i draon

velesgon plants growing closely together so one can't get through bus i fas

vene place, owned area of land, place belonging to person or community ples, olsem ples blong man, ples we ol pipol ol i stap long hem

vanan her/his/its place $\sim$ ples blong hem

vënëk my place ples blong mi 
vere wutwut mound, pile, rise of land from where one can see over lower land hip, hip blong graon o sanbij o smol top blong hil

vōnō $\mathbf{1} \bullet$ island aelan $\mathbf{2} \bullet$ village $\sim$ vilej nögö vōnō whole village, look or appearance of village $\sim$ eria blong vilej

vōr volcano volkeno

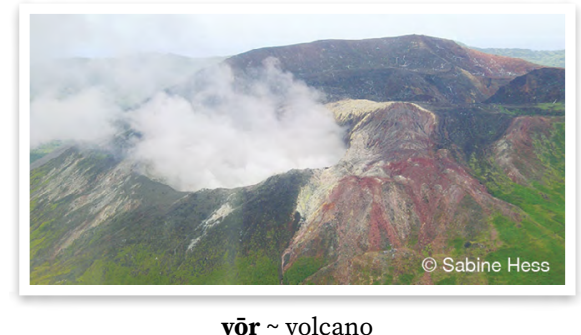

wömöötmöt area of bush, uninhabited area away from villages $\sim$ eria blong bus

\section{A2 Celestial features}

\section{$\mathbf{l o}_{1} \mathbf{1} \cdot \operatorname{sun} \sim \operatorname{san}$}

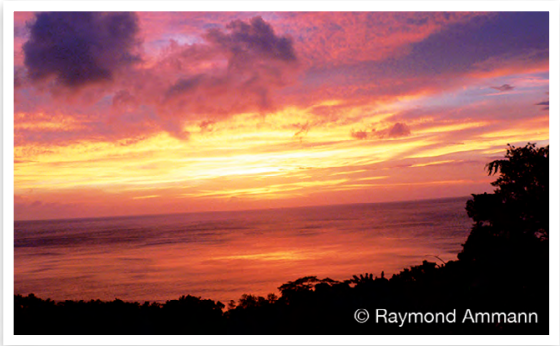

$1 \overline{\mathbf{o}} \sim \operatorname{sun}$

maē sky, open sky, high in air skae, antap long ea

wamas̄e $\overline{\mathbf{e}}_{1}$ star sta

wōl 1 1 moon mun

wōlmeeñ new moon fes saen blong mun i kam antap, taem i gat mun be i no saen gud yet

wōlmian full moon ful mun

wōlōbōl new moon niu mun

wōlsial moon that is visible during daylight $\sim$ mun we i stap antap yet taem i deilaet finis

\section{A3 Water}

\section{A3.0 General}

$\mathbf{b} \overline{\mathbf{e}}_{1} \mathbf{1} \cdot$ fresh water $\sim$ freswota $\mathbf{2} \cdot$ river $\sim$ wota

bē mamas dry creek bed drae wota, rod blong wota

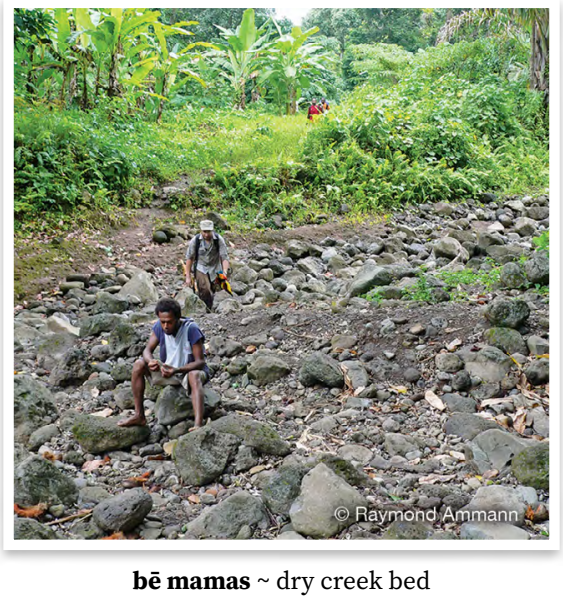

kērē bē mouth of river, place where river meets sea as blong wota, ples we wota i joenem solwota

mete bē source of river, creek ae blong wota, ples we wota i stat nögö bē place where the irrigation channel is directed into a taro paddy $\sim$ ples we ol i joenem wota i go insaed long garen taro

nötu bē stream smol reva

bēn lo brackish water, spring water that comes up by the sea and thus is slightly salty but drinkable wota we i spring aot long solwota, yu save dring be i sol smol

döw wet, be wet $\sim$ wetwet

lam deep water, deep freshwater pool, deep sea dip wota, dip solwota, dip ples

butölam very deep sea solwota $\mathrm{i}$ dip olgeta

vētitnē lam deep sea between islands medel si bitwin tu aelan '̄ōrmōōrse bubbles, foam babol 
mōōmōōsenaw sea foam spet blong solwota

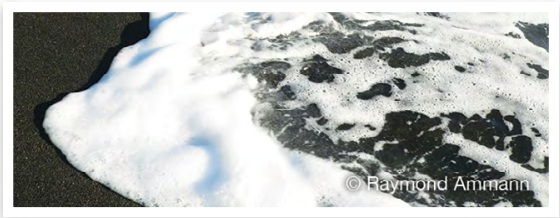

mōōrmōōrsenaw sea foam

$\mathbf{q} \overline{\mathbf{o}} \mathbf{S}_{2}$ run strongly, rapidly (of water) (wota i) ron strong qōsqōs large movement of water, as in wake of boat, water stirred up by propellers, etc. wota i muv bigwan, olsem from enjin blong bot

raras shallow, shallow place $\sim$ salo, ples we wota i no dip

sēriv waterfall wotafol

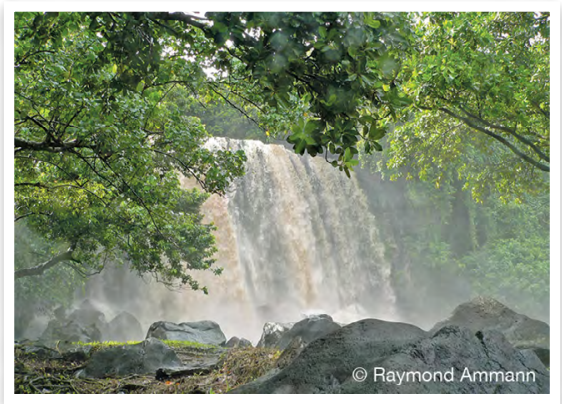

sēriv waterfall

taw $_{5}$ watercourse that starts after rain in a place where there was no water before wan wota we i stat niu long ples we i drae o i nogat wota bifo, be afta $i$ ren mo i gat wota

tin̄i $1 \cdot$ liquid, juice from something, as from fruit or sauce, liquid from cooked food wota (blong frut, kakae) $\mathbf{2}$ - sap of plant wota blong wud

tul $1 \cdot$ drown, fall down from height draon $\mathbf{2} \cdot$ submerge $\sim$ draonem

tul viteg draonem i go

ut ${ }_{2}$ collect water $\sim$ kasem wota
A3.1 Precipitation

deli very heavy rain $\sim$ ren we i strong we i strong

mërëv mist, fog sno, samting olsem smok we i kavremap ples taem i kolkol

miöw mist, fog samting olsem smok we i kavremap ples taem i kolkol ninin shower, light rain smol ren re $\overline{\mathbf{e}}_{2}$ rain $\sim$ ren

ten $_{3}$ rain $\sim$ ren

wian 1 rain $\sim$ ren

löt wian get rained on, not worry about getting wet in rain $\sim$ swim long ren

\section{A3.2 Water sources}

$\mathbf{b} \overline{\mathbf{e}}_{1} \mathbf{1} \cdot$ fresh water $\sim$ freswota $\mathbf{2}$ - river $\sim$ wota

bē mamas dry creek bed $\sim$ drae wota, rod blong wota

kērē bē mouth of river, place where river meets sea as blong wota, ples we wota i joenem solwota

mete bē source of river, creek ae blong wota, ples we wota i stat

nögö bē place where the irrigation channel is directed into a taro paddy ples we ol i joenem wota i go insaed long garen taro

nötu bē stream smol reva

mete qōsqōs source of spring water ples we spring wota i stat long hem mete vuvrës source of spring water ples we spring wota i stat long hem metewōs water source ples we wota i kamaot long hem

qulös pool pul

sol flow heavily (wota i) ron bigwan

A3.3 The ocean

beret $_{2}$ surface of sea antap blong solwota

dōrdōrse naw tideline ples we solwota i finis long hem

lum (tide) come in (solwota i) kamso 
met mö lum high tide, tide coming in solwota i kam so

met area of reef close to shore that is covered during high tide but exposed during low tide $\sim$ rif, ples we solwota mo rif i stap tugeta mo man i save wokabaot long hem mo yusum blong fising

met siag tide is neither high nor low solwota i stap semak nomo, i no save drae mo i no save kam so.

met sörlav time when there is a very high high tide $\sim$ taem we solwota $i$ kam so we i bitim mak blong evri dei long manis

mësu met ōrōr extreme low tide, which enables reef gleaning of species that would normally not be accessible $\sim$ taem solwota i drae bigwan, mo i minim se yu save karem sam mit we mos taem i stap long dip ples

met mō ōr low tide, tide going out solwota i drae

naw $\mathbf{1} \bullet$ sea $\sim$ solwota $2 \cdot$ sea water, salty water $\sim \operatorname{solwota} \mathbf{3} \cdot$ wave (of sea) $~$ wef (blong solwota)

dōrdōrsenaw tide mark mak we solwota i kam so, we yu harem noes blong solwota long ples ia nawēut rough sea solwota i raf nere on stretch of beach where the sand meets the sea ples we sanbij i kasem solwota

nilinaw wave $\sim$ wef

rēr tide $\sim$ taed

siōl go ashore kamso

$\operatorname{tar}_{2} \mathbf{1} \cdot$ calm sea $\sim$ solwota i kwaet $\mathbf{2}$ • (sea) become calm solwota i kam kwaet

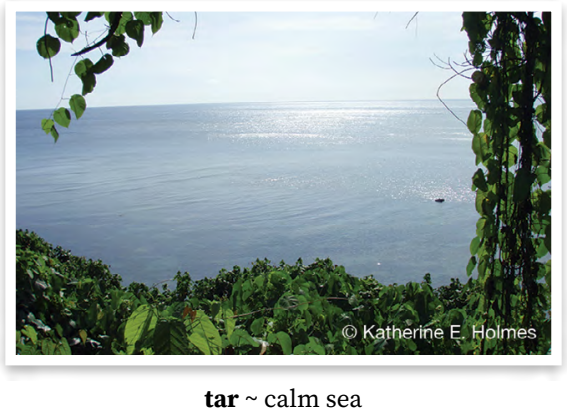

tiabasas go ashore kamso

viaw mes sea is neither calm nor rough solwota i no raf be i no kwaet

A4 Geological, other substances

lolov tsunami, tidal wave $~$ sunami, bigfala wef

rir earthquake etkwek

\section{B Weather and cyclic time}

\section{B1 Meteorological conditions}

butöliaw rainbow $\sim$ renbo

len $\overline{\mathbf{n}}_{1} \mathbf{1} \cdot$ wind $\sim$ win $\mathbf{2} \cdot$ air $\sim$ win

leñlimerlav southeast tradewind

$\sim$ tokelau, saotis win we i kam long Mere Lava

len̄limot northeasterly wind win i kam long notis long Mota

len̄lirō northerly wind win i kam long not long Reef Aelan

leñvus hurricane, cyclone $\sim$ hariken malēg cloud klaod

masalav southerly wind $\sim$ win we

i kam long saot

men $_{2}$ thunder $\sim$ tanda

mëw $\mathbf{w}_{2}$ dew $\sim$ drop wota long gras long

eli moning

rēe rain $\sim$ ren

sēlēg dark and cloudy, rain clouds tudak klaod, saen blong ren sēsēlēg dark, of sky, place (ples i) tudak 
taqtaq overcast, cloudy gat klaod, i no san be i no ren

ten $_{3}$ rain $\sim$ ren

tōk blue sky blu skae

tōkmereñ clear blue sky with no clouds skae we i blu nomo mo nogat klaod

tōwlo westerly wind $\sim$ win we i blo long wes

vēl lightning laetning

wian $_{1}$ rain $\sim$ ren

löt wian get rained on, not worry about getting wet in rain $\sim$ swim long ren

B2 Cyclical time

\section{B2.1 Diurnal cycle}

lölön̄ö vōrōg dawn, early morning eli moning

luwömeren midday, middle of day medel dei

meren $\mathbf{1} \cdot$ day, daytime $\sim$ dei $\mathbf{2} \cdot$ daylight $\sim$ deilaet $\mathbf{3} \cdot$ be daylight, become day $\sim$ kam deilaet

qön̄ $\mathbf{1}$ • night $\sim$ naet $\mathbf{2} \cdot$ day (as measurement of time) $\sim$ dei (olsem blong tokbaot hamas dei) $\mathbf{3}$ • become day kam dei

revrev late afternoon, evening; period preceding and following sunset aftenun, ivining

tinësqöñ middle of night $\sim$ medel naet vōrōg $\mathbf{1} \cdot$ morning moning $\mathbf{2}$ • be morning kam moning

\section{B2.2 Lunar cycle}

wōl 1 1 moon mun $\mathbf{2} \cdot$ month $\sim$ manis wōlmeeñ new moon fes saen blong mun i kam antap, taem i gat mun be i no saen gud yet

wōlmian full moon ful mun

wōlōbōl new moon niu mun

wōlsial moon that is visible during daylight $\sim$ mun we i stap antap yet taem i deilaet finis
B2.3 Seasonal cycle

mar famine taem we i nogat kakae $\overline{\mathbf{m}} \overline{\mathbf{o g}} \mathbf{\mathrm { t }} \mathrm{t}_{2}$ name of a season, when $\bar{m} \bar{o} g \bar{t} t$ flowers, just before dry season of rar, roughly February, March nem blong wan sisen blong yia, taem blong $\bar{m} \overline{o g} \bar{t}$ i gat flaoa, bifo long drae sisen

$\operatorname{rar}_{3}$ season when rar flowers, time of dry, cold weather, April to August sisen we narara hem i gat flaoa, hem i taem blong kolkol, stat long Eprel kasem long Ogis

to $\mathbf{1} \cdot$ year $\sim$ yia $\mathbf{2} \cdot$ season $\sim$ taem töu len hurricane season $\sim$ taem blong win, taem blong saeklon

\section{B2.4 Weekly cycle}

garqe $\mathbf{1} \cdot$ today $\sim$ tede $\mathbf{2} \cdot$ later on today, today in the afternoon or evening; earlier today, earlier the same day tede long aftenun, tede long moning finis $\mathbf{3} \cdot$ at the present time or age; these days $\sim$ long taem tede

in̄ko now $\sim$ nao

Made Monday Mande

nonor yesterday yestedei

nonorēs recent time period before yesterday $\sim$ bifo yestedei

naēs when $\sim$ wataem

orēs time period in the near future, after tomorrow afta tumoro

Qön̄ nirō Tuesday Tusde

Qön̄ nitöl Wednesday Wenesde

Qön̄ nivet Thursday Tasde

Qöñ tevelēm Friday Fraede

Sade Sunday $\sim$ Sande

Sarere Saturday $\sim$ Sarede

tōlōw tomorrow tumora

wik week wik

B3 Geological events

lolov tsunami, tidal wave $\sim$ sunami, bigfala wef

rir earthquake etkwek 


\section{Spatial relations}

CO General

$a_{1}$ locative, to, at, marking absolute location nouns long, maka we i go wetem ol nem blong ples

aqit (root qit) far longwe, farawe

arës (root rës ${ }_{2}$ ) distant, far, far away longwe, farawe

beriri side $\sim$ saed

bersi side, edge $\sim$ saed

$\mathbf{e}_{2} \mathbf{1}$ - that, distal modifier; as a modifier of locationals, indicates a greater distance $\sim$ ia longwe

gēn (fr.var. gēnak; igēn) this, this one, proximal demonstrative $\sim$ ia, hemia ilēkè (fr.var. lēkē) that one over there, distal presentative $\sim$ hemia longwe

iloko (fr.var. loko) this here, proximal presentative $\sim$ hemia, hemia ia

ilsi end $\sim$ en

ine (abbrev. ne) that, anaphoric demonstrative, referring back to a previously mentioned participant or event $\sim$ ia, wan samting we yu bin tokbaot finish

in̄ke this, this one, proximal demonstrative $\sim$ ia, hemia

$\mathbf{k a l}_{2} \mathbf{1} \cdot$ go up, motion or event directed upwards go antap $\mathbf{2} \cdot$ go landward, ashore, inland go antap long so, long bus $3 \cdot$ go upstream $\sim$ go antap (folem wota) $\mathbf{4} \cdot$ travel in a southeasterly direction (of travel beyond island to other islands) go long saot long narafala aelan $\mathbf{5} \cdot$ go inside, enter $\sim$ go insaed

kalō go outside $\sim$ go aotsaed

ken (fr.var. iken; ikene; kene) that one, that one there, distal demonstrative $\sim$ hemia

kikse side (of) saed (blong)

ko ${ }_{1}$ this, proximal modifier $\sim$ ia kulë 2 - behind, at the back, after (place or event) bihaen, afta kulen rōrō behind the two of them bihaen long tufala

laln̄e underneath andanit

linereg inside $\sim$ insaed

lo ${ }_{2}$ locative preposition, to, at, on, marking common nouns $\sim$ long

$\mathbf{l} \overline{\mathbf{o}}_{2}$ out, come out, move out $\sim$ aot, kamaot

lölö ${ }_{2}$ inside $\sim$ insaed

masawre $2 \cdot$ place $\sim$ ples

me 1 - towards speaker, in a direction towards the deictic centre $\sim \operatorname{kam} 2$. close by, proximal location, close to deictic centre $\sim$ ia, ples klosap long man we i toktok

mēēē top of, above, over antap

net towards addressee, in direction or facing towards person being spoken to $\sim$ i go long man we yu toktok long hem

nögö 2 - front, at the front, before fran

oko (abbrev. $\mathrm{ko}_{2}$ ) here, proximal location ples ia

qese top (of something tall, as person's head or hill) top (blong wan samting we i tolfala, olsem man o hil)

qese tōw top, peak of hill top blong hil

qötu $\mathbf{2}$ - top top $\mathbf{3} \cdot$ front, as in bow of ship, front of canoe, car $\sim$ fored, olsem blong kenu o trak

qötu vōnō area of village that is the section or edge towards the inland pat blong vilej we i stat long saed i go antap long bus

rivteg $\mathbf{1}$ - near, close by $\sim$ klosap 2 • near to, close to $\sim$ klosap long 
rōw 2 1 seaward, in a direction out to sea $\sim$ daon long solwota $2 \cdot$ outside $\sim$ aotsaed $\mathbf{3} \cdot$ go out, go outside $\sim$ go aotsaed, kamaot $4 \cdot$ come out and show oneself, appear to $\sim$ kamaot long

$\operatorname{sar}_{2} \mathbf{1} \cdot$ inland, landward $\sim$ antap (long bus) $\mathbf{2} \bullet$ inside $\sim$ insaed

$\operatorname{siag}_{2} \mathbf{1} \cdot$ upward $\sim \operatorname{antap} \mathbf{2} \cdot$ to the left when facing the sea, of places which are some distance away, not close by fes i go daon long solwota, go long lefsaed, be longwe lelebet

sōw $1 \cdot$ towards the right when facing the sea, in a clockwise direction around the island sapos yu fes $i$ go daon long solwota, go long raetsaed 2 - down, downwards, down low $\sim$ daon, stap daon $\mathbf{3} \cdot$ go down $\sim$ go daon

tavalgi $\mathbf{1} \bullet$ side $\mathbf{2} \cdot$ end $\sim$ en

tawle under, underneath $\sim$ andanit

teqeñ top top

tēqēl $1 \cdot$ go down, motion or event directed downwards $\sim$ go daon $\mathbf{2}$ • go seaward, go further out to sea go long solwota $\mathbf{3} \cdot$ go downstream $\sim$ go daon (folem wota) $4 \cdot$ travel in a northwesterly direction (of travel beyond island to other islands) $\sim$ go long not long narafala aelan

tëwru back bihaen

tuwur (fr.var. töwör) behind bihaen tutuwur after afta; bihaen

varē outside, open space outside of an enclosed space, as outside a house, in the open area of a village, on an open vehicle $\sim$ aotsaed

wōl ${ }_{2}$ to the left when facing the sea, in an anticlockwise direction around the island $\sim$ fes $i$ go daon long solwota, go long lefsaed
C1 Absolute direction

$\mathbf{k a l}_{2} \mathbf{1} \cdot$ go up, motion or event directed upwards go antap $2 \cdot$ go landward, ashore, inland go antap long so, long bus $3 \cdot$ go upstream go antap (folem wota) $\mathbf{4} \cdot$ travel in a southeasterly direction (of travel beyond island to other islands) $\sim$ go long saot long narafala aelan $\mathbf{5}$ - go inside, enter $\sim$ go insaed

rōw $\mathbf{w}_{2} \mathbf{1} \cdot$ seaward, in a direction out to sea $\sim$ daon long solwota $2 \cdot$ outside $\sim$ aotsaed $\mathbf{3} \cdot$ go out, go outside $\sim$ go aotsaed, kamaot $4 \cdot$ come out and show oneself, appear to $\sim$ kamaot long

$\operatorname{sar}_{2} \mathbf{1} \cdot$ inland, landward $\sim$ antap (long bus) $2 \cdot$ inside $\sim$ insaed

sōw $1 \cdot$ towards the right when facing the sea, in a clockwise direction around the island sapos yu fes $i$ go daon long solwota, go long raetsaed 2 - down, downwards, down low $\sim$ daon, stap daon $\mathbf{3} \cdot$ go down $\sim$ go daon

tēqēl 1 - go down, motion or event directed downwards $\sim$ go daon 2 • go seaward, go further out to sea go long solwota $\mathbf{3} \cdot$ go downstream $\sim$ go daon (folem wota) $\mathbf{4} \cdot$ travel in a northwesterly direction (of travel beyond island to other islands) $\sim$ go long not long narafala aelan

wōl ${ }_{2}$ to the left when facing the sea, in an anticlockwise direction around the island fes i go daon long solwota, go long lefsaed

\section{Demonstratives}

$\mathbf{e}_{2} \mathbf{1}$ that, distal modifier; as a modifier of locationals, indicates a greater distance $\sim$ ia longwe 2 - emphatic demonstrative, when modifying pronouns, specifies emphasis $\sim$ ia nao 
gēn (fr.var. gēnak; igēn) this, this one, proximal demonstrative $\sim$ ia, hemia ia here $\sim$ ia

ilēkē (fr.var. lēkē) that one over there, distal presentative hemia longwe

iloko (fr.var. loko) this here, proximal presentative $\sim$ hemia, hemia ia

ine (abbrev. ne) that, anaphoric demonstrative, referring back to a previously mentioned participant or event $\sim$ ia, wan samting we yu bin tokbaot finish

in̄kē this, this one, proximal demonstrative $\sim$ ia, hemia

ken (fr.var. iken; ikene; kene) that one, that one there, distal demonstrative $\sim$ hemia

ko this, proximal modifier $\sim$ ia

me 1 - towards speaker, in a direction towards the deictic centre $\sim \operatorname{kam} 2 \cdot$ close by, proximal location, close to deictic centre $~ i a$, ples klosap long man we i toktok

oko (abbrev. $\mathrm{ko}_{2}$ ) here, proximal location ples ia

soko emphatic marker, expression of surprise or emphasis regarding an item or event $\sim$ hemia ia

\section{C3 Pronouns}

dōrōk we two, us two; first person dual inclusive pronoun $\sim$ yumitu

kemem (fr.var. kemek) we, us; first person plural exclusive pronoun mifala

kēmi (fr.var. kimi) you, you all; second person plural pronoun yufala

kōmōrōk we two, us two; first person dual exclusive pronoun $\sim$ mitufala

kōmōrōñ you two; second person dual pronoun $\sim$ yutufala

nē he, she, it, him, her; third person singular pronoun $\sim$ hem

nēk you; second person singular pronoun $\sim$ yu

nēn (fr.var. $\operatorname{nin}_{2}$ ) we, us; first person plural inclusive pronoun $\sim$ yumi

nèr they, them; third person plural pronoun olgeta

no I, me; first person singular pronoun $\sim \mathrm{mi}$

rōrō they two, them two; third person dual pronoun $\sim$ tufala

\section{Plants}

\section{Do General}

butu thorn (of citrus fruits) nil (blong aranis)

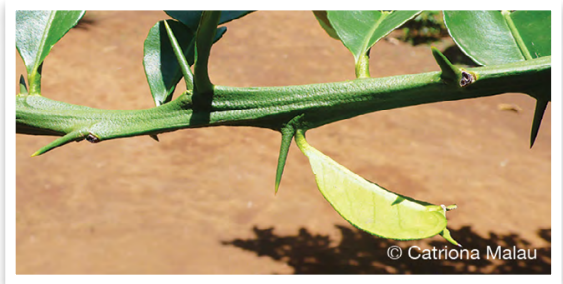

butu thorn (of citrus fruits) bōl ${ }_{2}$ unripe, ripening but not yet ripe $\sim$ klosap i raep be i no raep gud yet

bur ñe canarium sap wota blong nangae

damarēnit pandanus leaves that have dried on the branches $\sim$ lif pandanas we i drae nomo long stamba

dege leaf $\sim$ lif

delti buttress root, kind of tree root which starts high up on the trunk and is wide and long, reaching down to the ground $\sim$ kaen rus blong wud we hem i stat antap long stamba 
mo i kasem daon long graon, olsem blong nakatambol, bluwota, siok, natavoa o namambe

devga sago palm leaf that is dry and has brown mark on it lif natanggura we i gat braon mak olsem i drae

dödöu leaf, leaf of (a particular plant) $\sim$ lif, lif blong (wan tri)

gagarēn aerial roots $\sim$ rus we i gro antap

gagö $1 \cdot$ stem or runner of vine longfala gro blong rop

gamesel midrib, midvein of Heliconia indica leaf, when removed (and used for tying up food parcel, etc.) bun blong lif laplap

gèri root rus

keresi thorn (of wild yam, Chinese yam, umbrella leaf) nil blong wael yam, swityam, ambrela lif

labēvi stem or petiole and leaf of palm or non-branching plant, as taro, tree fern, coconut, sago palm; rachis, principal midrib han blong wud olsem kokonas o blakpam o taro

lēlē nearly ripe, of bananas which are ripe enough to eat, but still slightly unripe klosap raep, olsem banana we $\mathrm{i}$ gud blong kakae be $\mathrm{i}$ no raep gud yet

löv orchard, plantation, area where lots of useful plants and fruit and nut trees are planted for future generations $~$ ples we ol i planem fulap stamba blong frut o nat mo ol yusful plant long hem blong ol man long fiuja i save karem

mian ripe $\sim$ raep

nalte sap wota (blong wud)

nili (fr.var. n̄ēli) shoot, sprout, new growth of plant $\sim$ top blong wud, gru blong plant

nili pomken new growth of pumpkin plant, eaten as greens $\sim$ top blong pomken we hem i wan kabis nili qiat taro stems top blong taro

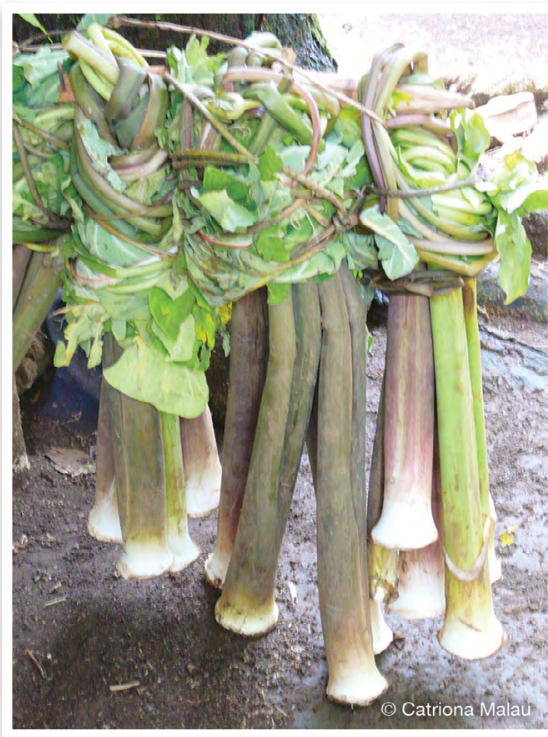

nili qiat $~$ taro stems

$\overline{\mathbf{o}} \mathbf{w}_{2}$ bear fruit karem kakae

qar $\mathbf{1}$ - unripe no raep $2 \cdot$ raw, uncooked $\sim$ no dan $\mathbf{3} \cdot$ undried, untreated, as of green leaves, rather than dried or heat treated leaves no drae, no dan, olsem lif we i grin nomo, we ol i no putum long faea blong mekem i strong.

qere petiole stamba

qētēgi (fr.var. qētigi; qitēgi; qitigi) $\mathbf{1}$ • trunk (of tree), body of tree stamba qöqö young shoot yang lif qöqörö small leaf smol leaf qulön ring-like mark around wood or plant stem, such as node of bamboo or sheath mark of sugarcane $\sim$ mak olsem ring we $i$ ronem samting olsem wud, bambu o sugaken

rērēi ${ }_{1}$ branch of tree or other plant han blong wud

sili sucker of banana, shoots from taro or other tubers, used to propagate new plants saka, olsem blong banana o narafala plant, blong planem 
siri $2 \cdot$ midrib, midvein of leaf, leaflet $\sim$ bun blong lif

siri qatē pieces from inside of trunk of tree fern, which is composed of layers of old branches that are brittle ol sap pisis blong insaed blong blakpam

$\mathbf{t a w}_{3}$ produce flower (plant) mekem flaoa

tawagas flower flaoa

tebe frond, leaf of palm tree or palmlike leaf $\sim$ lif blong pamtri

tewes flower of (a plant) flaoa blong (wan samting)

tinini $1 \cdot$ liquid, juice from something, as from fruit or sauce, liquid from cooked food wota (blong frut, kakae) $\mathbf{2}$ - sap of plant wota blong wud

tin̄i mōtō liquid from coconut (green or dry) wota blong kokonas (grin o drae)

turgēn $\mathbf{1} \cdot$ body bodi $\mathbf{2} \cdot$ trunk of tree $\sim$ stamba blong wud

vinti (fr.var. vēnti) $2 \cdot$ bark skin blong wud $3 \cdot$ husk (of nut, coconut), skin (of fruit, vegetable) skin blong nat o kokonas

vötu 1 - (of tree), trunk, above bole stamba, pat blong stamba daon

wēsiri sharp needle-like piece from inside of base of sago palm rachis bun blong natanggura insaed long stamba

wiē fruit (of tree), generic term for fruit of plant frut (blong wud) wian $_{2}$ its fruit $\sim$ frut blong hem

wōtōgsiar midrib of sago palm leaf which is used to make brooms $\sim$ bun blong lif natanggura we ol i yusum blong mekem brum

wösöwu seed $\sim \operatorname{sid}$
D1 Trees and palms

$\mathbf{a r}_{1}$ (fr.var. waar) kind of tree $\sim$ wan kaen tri Premna corymbosa ar ōl kind of ar tree that grows in the bush wan kaen ar tri blong bus ar tur kind of ar tree that grows near the sea and is a strong tree which does not bend wan kaen ar tri we i stap long solwota mo i strong mo i no save benben

$\mathbf{b a k}_{1}$ generic name for banyan trees, kind of banyan with fruit that are round and light red when ripe $\sim$ wan kaen nambangga we frut blong hem i raon mo i grin mo taem i raep i red waet Ficus spp.

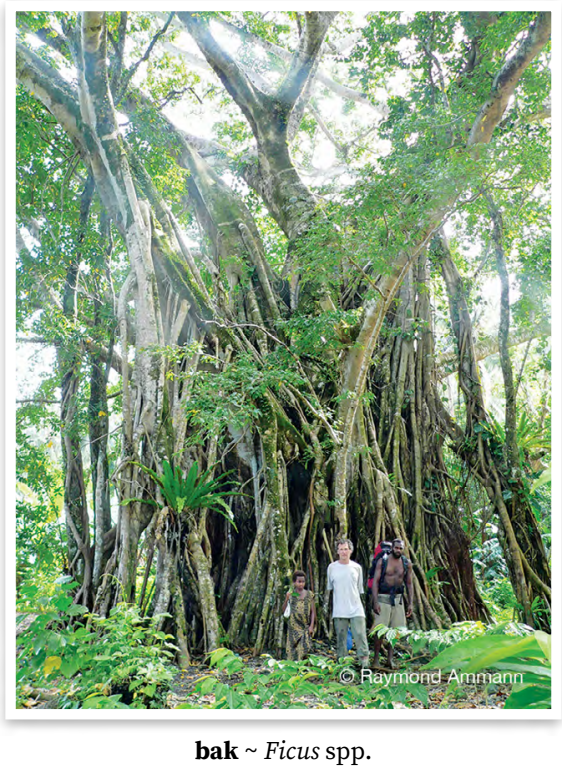

bak matqō kind of banyan with long fruit wan kaen nambangga we frut blong hem i longwan

balak variety of fig tree with edible fruit and leaves wan kaen tri we hem i famle blong nambangga mo yu save kakae frut mo lif blong hem Ficus wassa

dabalak leaf of balak that is eaten as wild greens $\sim$ lif blong balak we ol man ol i save kakae olsem bus kabis 
bar $_{3}$ kind of palm wan kaen pamtri Pelagodoxa henryana

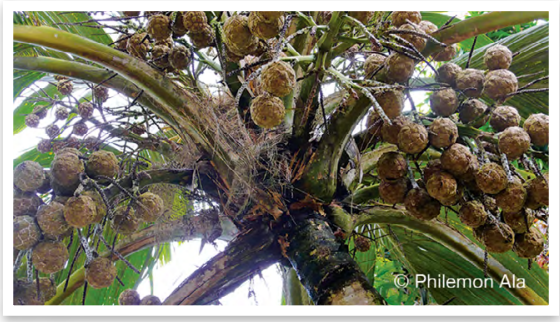

bar Pelagodoxa henryana

bēbètiq̄o kind of tree that has two varieties, one with white leaves, the other with red leaves. The wood is used for making arrows, and the leaves are used in traditional medicine wan kaen tri we $i$ gat tu kaen blong hem, wan lif i waet, narawan lif i red. Ol i yusum wud blong katem aro blong sutum pijin o faol. Ol i yusum blong lif meresin mo ol i melekem top blong hem blong smol pikinini

biēg breadfruit bredfrut Artocarpus altilis

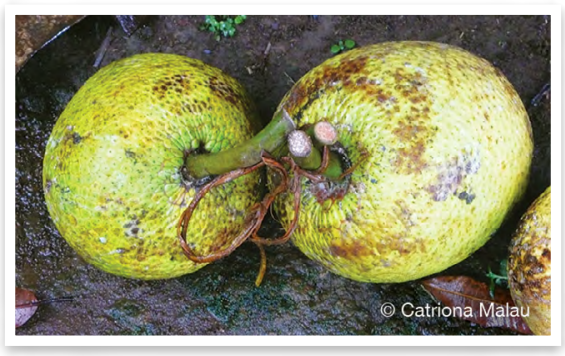

biēg Artocarpus altilis

birbir sea hearse, lantern tree $\sim$ nambirimbiri Hernandia nymphaeifolia

bitbitiq̄o kind of small tree with small red fruit and yellow flowers wan kaen tri we i smol mo frut blong hem i smol mo i red mo flaoa blong hem i yelo Psychotria trichostoma

boboros kind of tree related to balak, with small fruit that are white or pinkish when ripe $\sim$ wan kaen tri we hemi famle wetem balak. Kakae blong hem i smol mo taem i raep $\mathrm{i}$ waet o laet red

boboto cheese tree; kind of tree with small yellow flowers and small fruit that are black when ripe $\sim$ wael namamao, wan kaen tri we flaoa blong hem i smol mo i yelo mo frut blong hem i blak Glochidion sp.

bōgōr ballnut, Alexandrian laurel, beach mahogany, tamanu nambakura, tamanu blong solwota Calophyllum inophyllum

bōgōrēmēs kind of tree tamanu blong bus Calophyllum neo-ebudicum bul ${ }_{1}$ suicide tree, kind of tree with red or black fruit that has sticky sap wan kaen tri we frut blong hem i red o blak mo wota blong hem i olsem glu Cerbera manghas, C. odollam

bustutun kind of hardwood tree wan kaen wud Guettarda speciosa

dā̄amas kind of tree, one traditional use of which is to help crawling babies to be able to walk strongly wan kaen wud we kastom yus blong hem i blong ol pikinini we ol i wokabaot fo leg blong mekem se ol i save wokabaot strong

darag wild nutmeg nandae Myristica fatua

darag tōwlo kind of tree like wild nutmeg but which has larger fruit which are round wan kaen tri olsem nandae be kakae blong hem i bigwan mo i raon Myristica inutilis

datamalqō kind of tree wan kaen tri Pisonia grandis

datawalwal kind of small tree, grows to about 3 metres, with small yellow flowers and small fruit that are red when ripe $\sim$ wan kaen tri we kakae blong hem i smolsmol mo i grin be taem i raep i red, mo flaoa blong hem i yelo Phyllanthus ciccoides 
dēmērmēr tree fern blakpam Dicksonia spp.

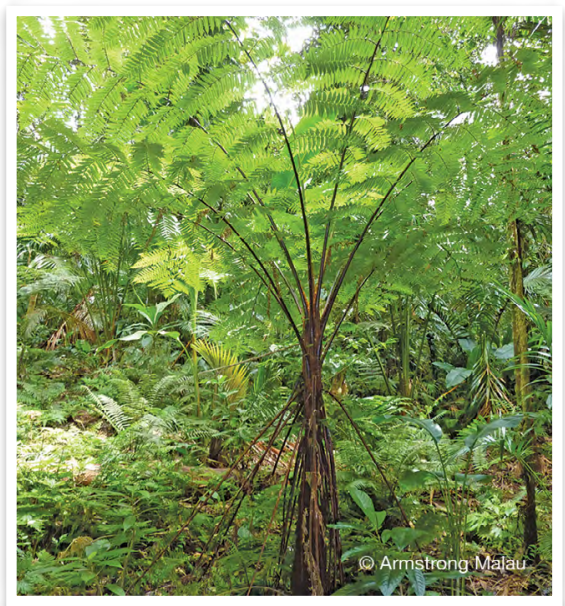

dēmērmēr Dicksonia spp.

dērvag beach pandanus

waelpandanas, wan kaen pandanas we $\mathrm{i}$ gro long solwota mo i save gro bigwan mo i gat longfala rus Pandanus sp.

dēsēn kind of tree wan kaen tri we i save gro eni ples

divivi umbrella leaf ambrela lif Licuala grandis

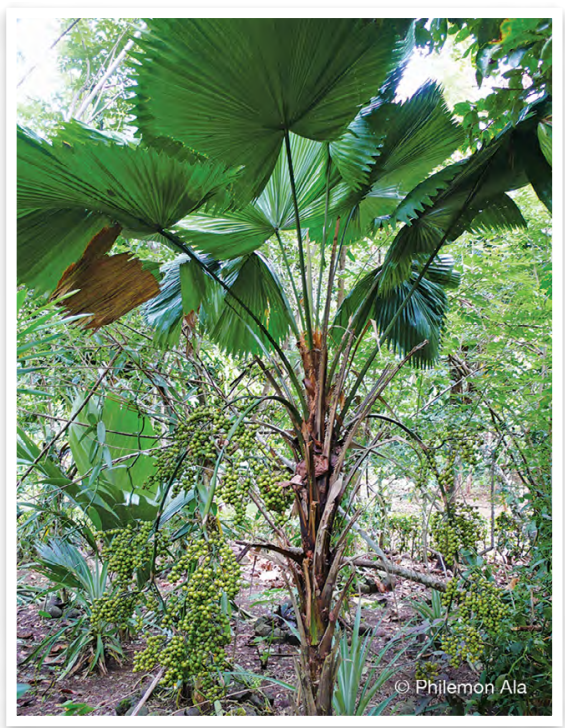

divivi Licuala grandis doot 1 - Vanuatu sago palm natanggura Metroxylon warburgii $\mathbf{2}$ • sago palm thatch $\sim$ lif natanggura, taj

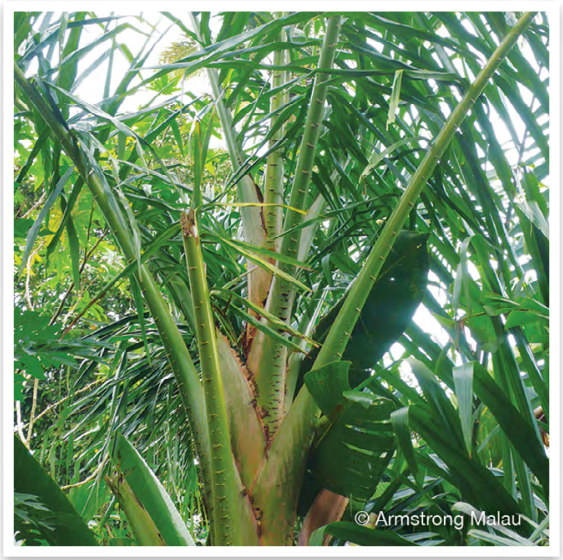

doot $\sim$ Metroxylon warburgii

dootnönqet wild bush pandanus that grows in moist environments. Leaves have very sharp edges waelpandanas blong bus we i laekem ples we i gat wota. Lif blong hem i sap mo i save katem yu Freycinetia sp.

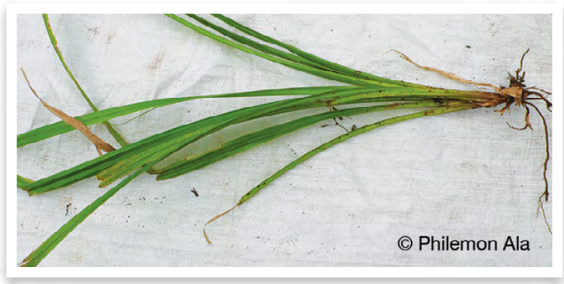

dootnönqet $\sim$ Freycinetia sp.

dōkōlōkōl kind of tree wan kaen tri Dillenia biflora

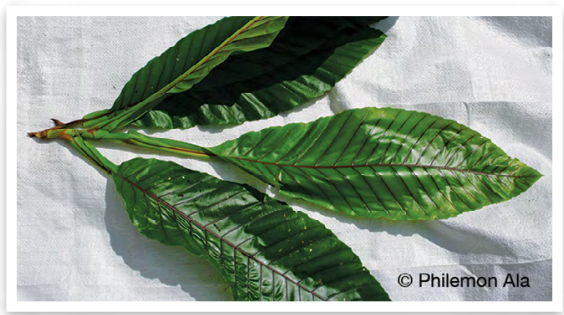

dōkōlōkōl Dillenia biflora 
dōmōvōtrev kind of small tree whose leaves close in the late afternoon wan kaen tri we lif blong hem i klos long aftenun Albizzia lebbeck

dōōt blind your eye, milky mangrove $\sim$ wan kaen tri Excoecaria agallocha

dōsōw kind of tree wan kaen tree Geniostoma rupestre

dōvōr nem kind of small tree wan kaen smol tri Vitex negundo

dötöl kind of tree with red flowers. Birds and flying fox eat the fruit wan kaen tri we i save gro bigwan mo i gat smel. Ol flaoa blong hem i red mo ol pijin mo flaengfokis i stap kakae

dunregōsōw kind of tree wan kaen tri

dun̄bönö Java cedar, bishop wood nakoka Bischofia javanica

ër casuarina, she-oak, beefwood, ironwood, whistling pine oktri, siok Casuarina equisetifolia

gan men species of fig tree which has fruit that is orange when ripe, growing close to the branch $\sim$ wan kaen tri we hem i famle blong nambangga, taem i raep, frut blong hem $i$ aranis Ficus tinctoria

gasēsēdignönqet kind of tree wan kaen tri Ficus aspera

gasōg tree with edible fruit wud we yumi save kakae frut blong hem Gnetum gnemon

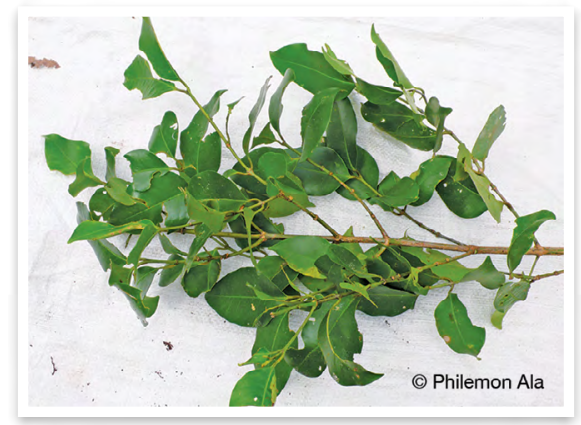

gasōg Gnetum gnemon gatötöqulqërët kind of dragon tree, shrubby plant wan kaen plant Dracaena sp.

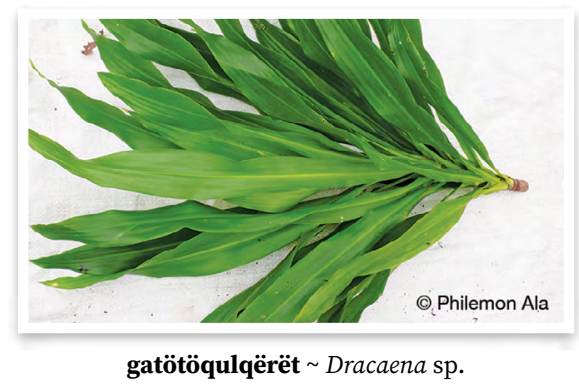

gavēg mountain apple, Malay apple, rose apple nakavika Syzygium malaccense

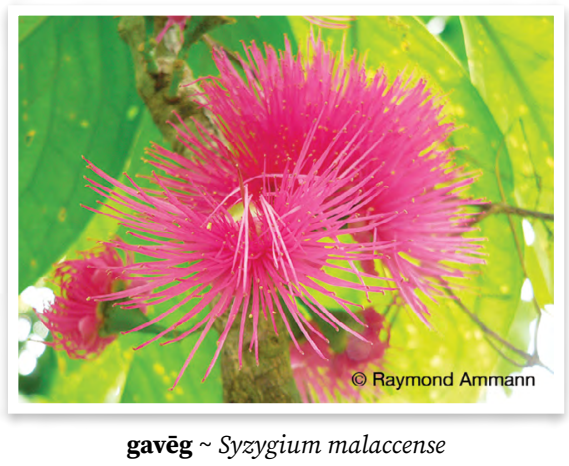

gavēgulul kind of tree like mountain apple but with white flowers wan kaen tri olsem nakavika be flaoa blong hem i waet

gavō whitewood waetwud Endospermum medullosum

gawōlo kind of tree that is used to make a strong rope $\sim$ wan kaen tri we $i$ gat rop blong hem insaed we $i$ strong tumas

gōglo kind of shrub, small tree kaen navenue Macaranga tanarius

les poisonwood posenwud Semecarpus neoebudica

mala kind of tree with fruit that is red on the outside and black inside $\sim$ wan kaen tri we frut blong hem i red long aotsaed, be insaed i blak Sterculia banksiana 
malagavēg kind of tree that is related to Malay apple, with pink flowers and small dark red to black fruit wan kaen tri we hem i famle blong nakavika, flaoa blong hem i pink mo frut i smolsmol mo i dak red o blak Syzygium buettnerianum

malaqōōr kind of tree with very long leaves that grows on the side of hills wan kaen tri we hem i gro long saed blong hil. Lif blong hem i longlongwan

malmalasē kind of tree wan kaen tri malnët kind of tree like red silkwood but the fruit are smaller and not eaten wan kaen tri olsem naduledule be kakae blong hem i smol mo man i no stap kakae

man̄ko mango manggo

markōn kind of tree wan kaen tri Metrosideros collina

marsam kind of tree, brown kurrajong wan kaen tri Commersonia bartramia

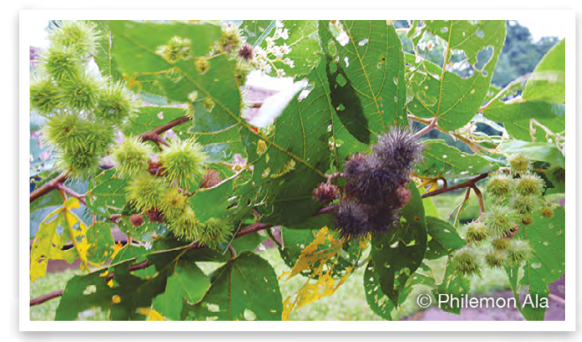

marsam Commersonia bartramia

matal puzzle tree namatal Kleinhovia hospita

menmav kind of tree, probably type of fig, with fruit that is green when unripe and white when ripe $\sim$ wan kaen tri we i olsem balak. Kakae blong hem $\mathrm{i}$ grin mo taem $\mathrm{i}$ raep $\mathrm{i}$ waet

meteraramat kind of tree kaen wud mē achiote, annatto; kind of shrub or small tree with bright red spiny fruits and red seeds wan kaen wud we $\mathrm{i}$ gat red frut blong hem wetem red sid insaed Bixa orellana

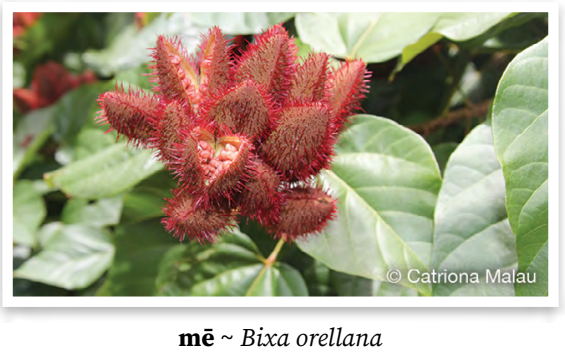

mēl kind of tree wan kaen wud Elaeocarpus floridanus

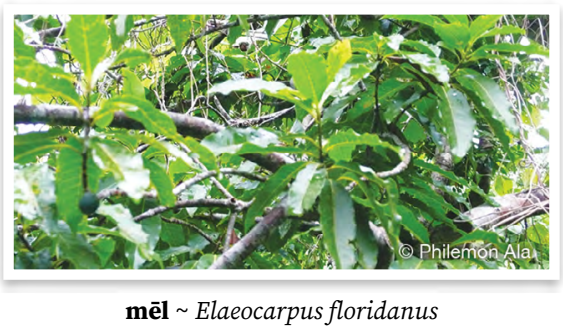

mōmō $\overline{\mathbf{m}}_{2}$ poumuli, tree species with small, black, inedible fruit namamao, namemiwa Flueggea flexuosa

mōtōvōl areca palm belonging to same family as betel nut kaen pamtri we i famle blong bitelnat Areca macrocalyx

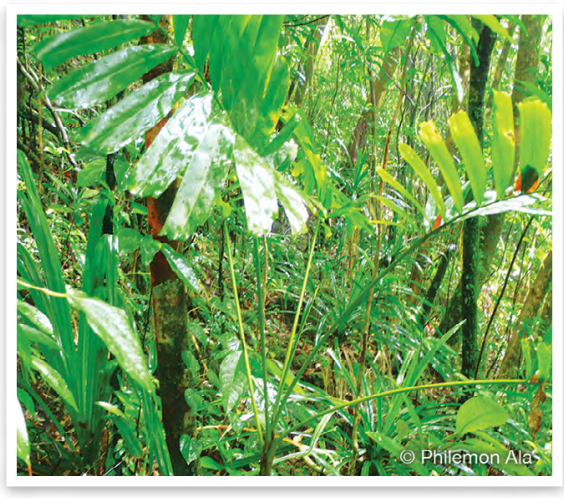

mōtōvōl Areca macrocalyx 
mēeriri kind of perennial climbing tree brata blong namariu; namariu blong solwota Acacia simplex

mēririnek kind of tree namariu blong solwota Acacia spirorbis

miak Tahitian chestnut $\sim$ namambe Inocarpus fagiferus

möll orange; generic term for citrus fruit, but mostly referring to orange $\sim$ aranis Citrus spp.

nagnagsamul kind of tree $\sim$ wan kaen tri

nanar New Guinea rosewood nananara, bluwota Pterocarpus indicus

nët red silkwood, large tree, growing up to 30 metres with large edible green fruit $\sim$ naduledule Burckella obovata

nōnōn kind of small tree wan kaen smol tri Ficus adenosperma

ne canarium nut, native almond nangae Canarium spp.

ne dawel kind of wild native almond which grows in the bush and is not eaten. It has white bark and can grow tall like a whitewood wan kaen wael nangae blong bus we ol man ol i no kakae. Skin blong hem i waet mo hem i save gro longwan olsem waetwud

ne dun kind of native almond which has flat nuts kaen nangae we i gat frut we i flat Canarium harveyi

ne ta kind of native almond which has round nuts kaen nangae we i gat frut we i raon Canarium indicum

òv canoe tree kenutri Gyrocarpus americanus

qate $\bar{e}_{1}$ tree fern blakpam Cyathea spp. qetge kind of tree $\sim$ wan kaen tri qēr ${ }_{1}$ kind of tree $\sim$ wan kaen tri Osmoxylon orientale

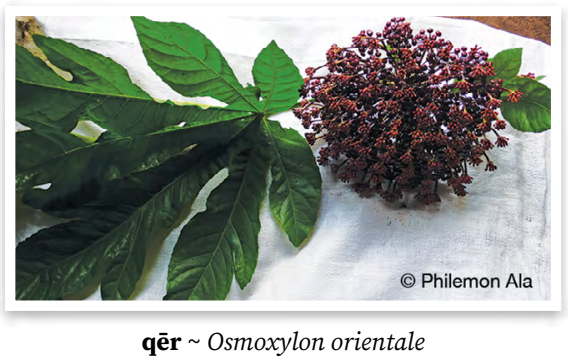

qog kind of tree wan kaen tri Neuburgia corynocarpa

qōmiat stinkwood; kind of tree with yellow fruit with red seeds inside stingwud; wan kaen tri we frut blong hem i yelo mo i gat red sid insaed Dysoxylum gaudichaudianum

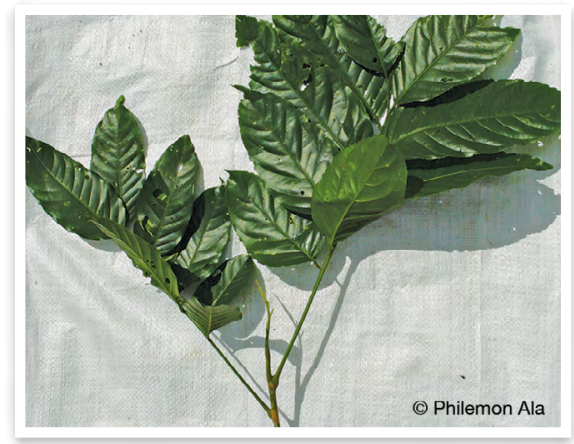

qōmiat Dysoxylum gaudichaudianum

$\mathbf{r a r}_{2}$ Indian coral tree $\sim$ narara Erythrina indica, E. variegata

rēntenge $1 \cdot$ tree, plant with woody trunk and branches, also covering palms, but not smaller shrubs tri, wud $\mathbf{2} \cdot$ wood, length of wood, stick, the wood of a tree $\sim$ wud

rēw kind of fig that does not have aerial roots. It has smaller fruits than a banyan, the fruits are red and yellow and eaten by birds wan kaen nambangga we rus blong hem i no kamaot antap. Frut blong hem i no bigbigwan tumas olsem nambangga. Ol frut ol i red mo yelo mo ol pijin ol i laek blong kakae 
rō $q_{3}$ kind of tree like a varvar which grows in the bush and has a thick double layer of bark wan kaen tri we $\mathrm{i}$ olsem varvar be $\mathrm{i}$ blong bus mo skin blong hem i strong dabol skin

rōwō kind of tree that has bark that is red on the underside $\sim$ wan kaen tri we insaed skin blong hem i red

$\mathbf{s a l}_{3}$ kind of tree $\sim$ wan kaen tri Homalanthus nutans

sawa mountain lantern tree bluwud Hernandia moerenhoutiana

sentawud sandalwood sentawud Santalum austrocaledonicum

sēqēg kind of tree wan kaen tri Elaeocarpus floridanus

sērsēr kind of tree like stinkwood but bigger and harder wood wan kaen tri olsem stingwud be i bigwan mo i strong

silat $1 \cdot$ nettle tree, fever nettle, devil nettle $\sim$ nanggalat Dendrocnide spp.

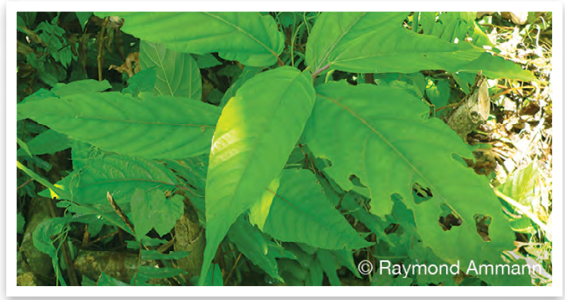

silat $\sim$ Dendrocnide spp.

silat gegeretō kind of nettle tree which has a powerful sting wan kaen nanggalat we hem i kakae man i strong

sōgsōggenqet kind of tree kaen wud Phaleria pentecostalis

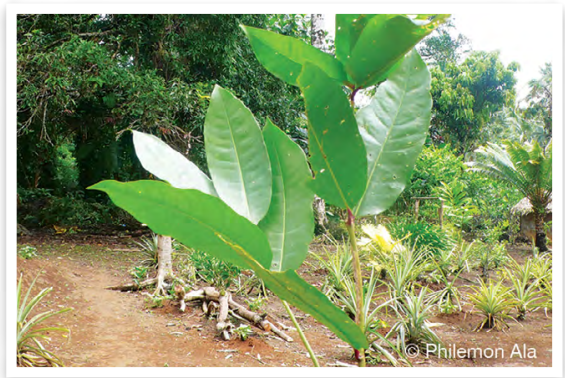

sōgsōggenqet $\sim$ Phaleria pentecostalis tagar $_{2}$ kind of tree $\sim$ wan kaen tri Melochia odorata

talēs sea almond, Indian almond natavoa Terminalia catappa

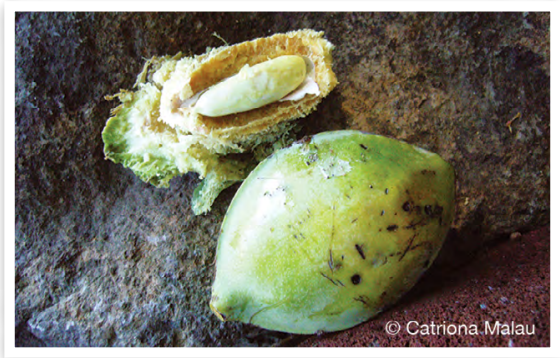

talēs Terminalia catappa

talēs toko kind of tree related to an Indian almond but which has small nuts wael natavoa Terminalia sepicana

tarak kind of tree wan kaen tri Ervatamia orientalis, E. pandacaqui, E. obtusciuscula

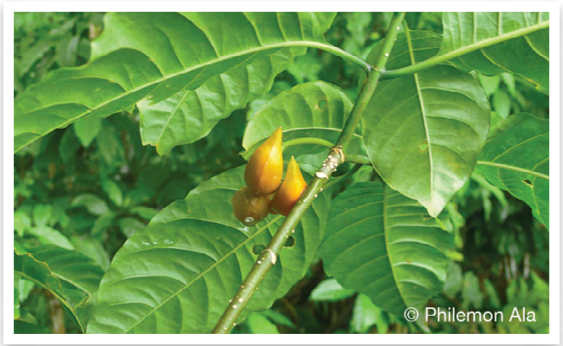

tarak Ervatamia orientalis

tewen native lychee $\sim$ nandao Pometia pinnata

tēq $q_{1}$ kind of tree with small black fruit $\sim$ wan kaen tri we kakae blong hem i smol mo taem i raep i blak Rhus taitensis

titiqō kind of tree kaen wud tor island teak, ironwood natora Intsia bijuga

totenanar kind of tree that has long white flowers with a strong perfume wan kaen tri we flaoa blong hem i waet mo i longlongfala mo i gat smel 
ur great hog plum naos Spondias dulcis

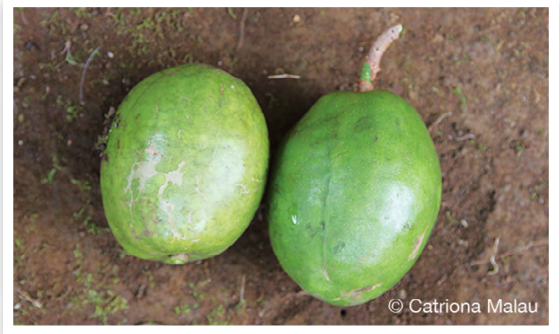

ur $\sim$ Spondias dulcis

usugiav kind of tree $\sim$ wan kaen tri we natora blong hem i blak Annona squamosa

$\operatorname{van}_{2}$ kind of pandanus that grows by the sea and has thorny leaves. The fruit is eaten by people and flying foxes $\sim$ wan kaen pandanas we i stap long solwota we $\mathrm{i}$ gat nil. Man mo flaengfokis ol i save kakae frut blong hem mo ol i juim mo afta spetemaot makas

varvar kind of tree wan kaen wud Neisosperma oppositifolia

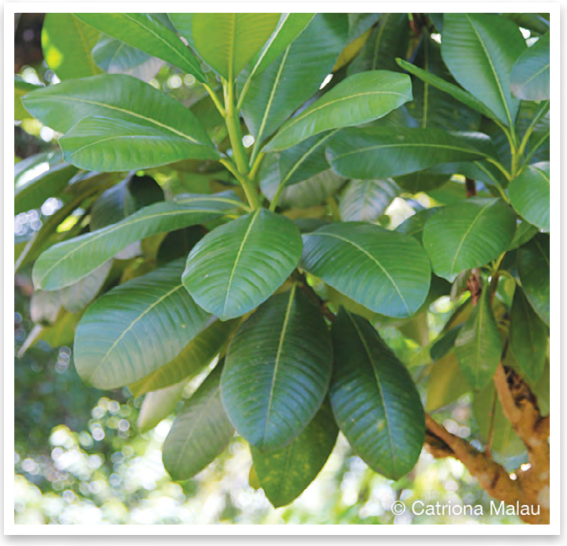

varvar Neisosperma oppositifolia

vēkēmolo kind of tree that grows to about 4 metres, with purple flower and brown fruit $\sim$ kaen tri we $i$ gat popel flaoa mo braon frut Psychotria aneityensis vēlavēl toi huremi, navasvas Alphitonia zizyphoides

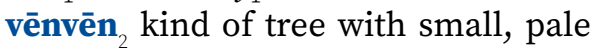
yellow flowers and small round fruit wan kaen tri we flaoa blong hem i smol mo i yelo mo kakae blong hem i raon Pavetta opulina

vètuboso kind of tree that has thick bark and roots similar to a mangrove wan kaen tri we skin blong hem i tik mo rus blong hem i olsem natongtong Crossostylis cominsii

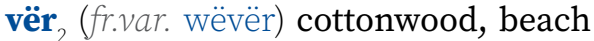
hibiscus burao Hibiscus tiliaceus

vōname kind of tree that has red flowers similar to a Malay apple. Flying foxes drink the nectar from the flowers wan kaen tri we flaoa blong hem i red mo i olsem nakavika be i strong. Flaengfokis i dring flaoa blong hem be ol i mas satem ae taem i dring o sapos no flaoa bae i stikim vudege (fr.var. vudëgë) pandanus, screw pine $\sim$ pandanas Pandanus spp.

vut fish poison tree, sea poison tree fisposentri Barringtonia asiatica

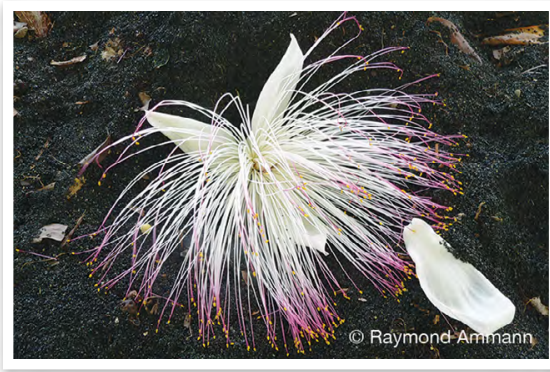

vut $\sim$ Barringtonia asiatica

wag $_{1}$ ylang-ylang, perfume tree nandingori Cananga odorata

wakam kind of tree with yellow flowers. It has nuts similar to native almonds which are yellow when ripe wan kaen tri we flaoa blong 
hem i yelo. Kakae blong hem i olsem nangae, i grin be taem i raep i yelo Finchia chloroxantha

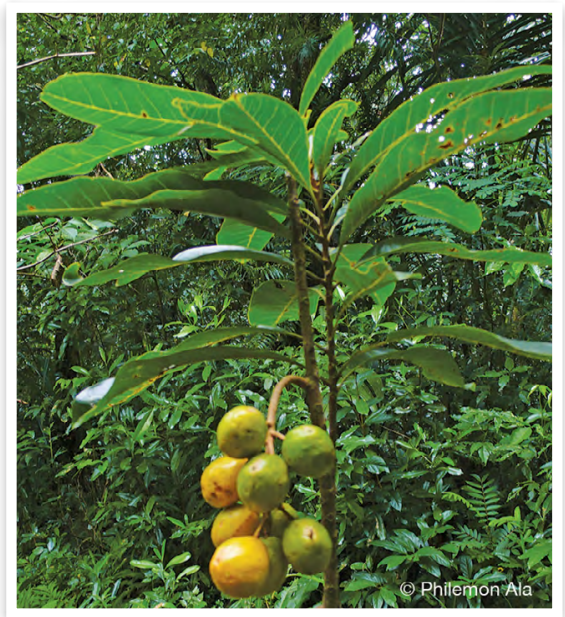

wakam Finchia chloroxantha

walag $_{1}$ kind of tree with large fruit with yellow skin and red seeds wan kaen tri we wud blong hem i strong mo frut blong hem i yelo mo insaed ol sid i red. Kakae blong hem i olsem kakae blong bintri Dysoxylum aneityensis

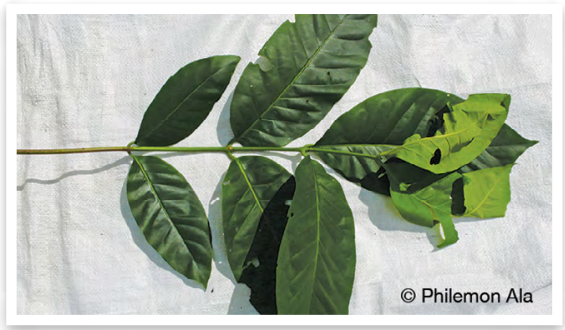

walag Dysoxylum aneityensis

wan̄arn̄ar kind of tree that has fruit similar to a mango which are red when ripe wan kaen tri we kakae blong hem i olsem manggo we i laet grin mo taem i raep i red Corynocarpus similis

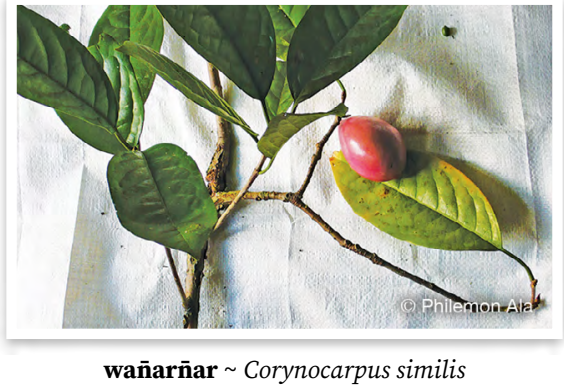

waran̄rañ marge kind of tree, fruit are red when ripe and similar to that of poumuli wan kaen tri we frut blong hem i red taem i raep mo hem i olsem kakae blong namamao Flacourtia rukam

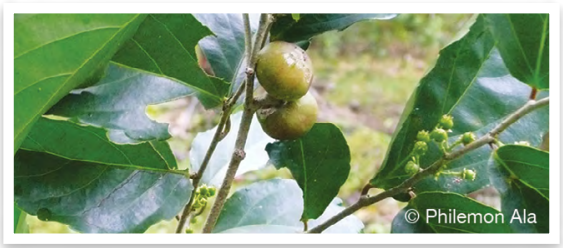

waran̄ran̄ marge Flacourtia rukam

watamarge kind of large tree with fruits which are similar to a Malay apple, but they are not commonly eaten as they are very sour. The fruit are red when ripe and long and oval shaped wan kaen tri we hem i bigwan lelebet. Kakae blong hem i olsem nakavika be man i no kakae tumas from i saoa. Taem i no raep i grin mo taem i raep i braet red. Hem i longfala lelebet Aceratium oppositifolium

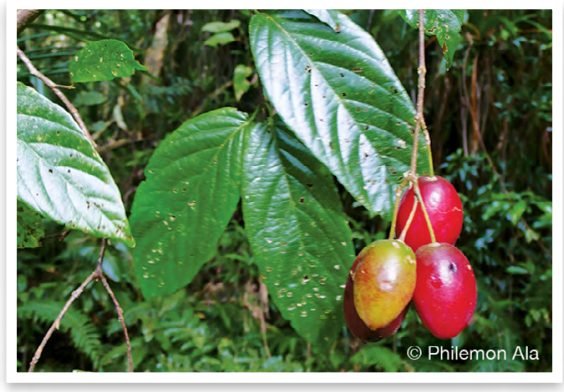

watamarge $\sim$ Aceratium oppositifolium 
wegerbak kind of tree wan kaen tri weverbak kind of tree $\sim$ wan kaen tri Olea paniculata

wēgēbil false tamanu; kind of tree with edible fruit that are dark red, black when ripe, red inside wan kaen tri we frut blong hem i dak red mo taem i raep i blak mo i red long insaed blong hem Garcinia pseudoguttifera

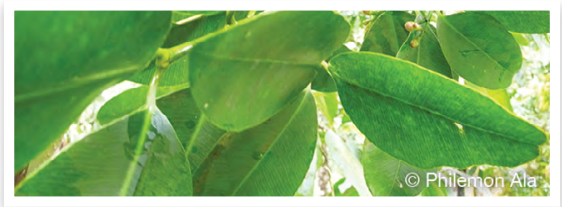

wēgēbil Garcinia pseudoguttifera

wēmētigtig betel nut, areca palm bitelnat, rabis kokonas, waelkokonas Areca catechu

wēqiar ${ }_{2}$ kind of small tree wan kaen smol tri Desmodium umbellatum

wequiqiar kind of tree that grows by the sea and has fruit that look like small beans wan kaen tri we i gru long solwota we kakae blong hem i olsem smolsmol bin

wètēt ${ }_{2}$ kind of tree wan kaen tri wēviriak rattle tree navangge Pangium edule

wēwēn red beadtree, coralwood nabisa Adenanthera pavonina

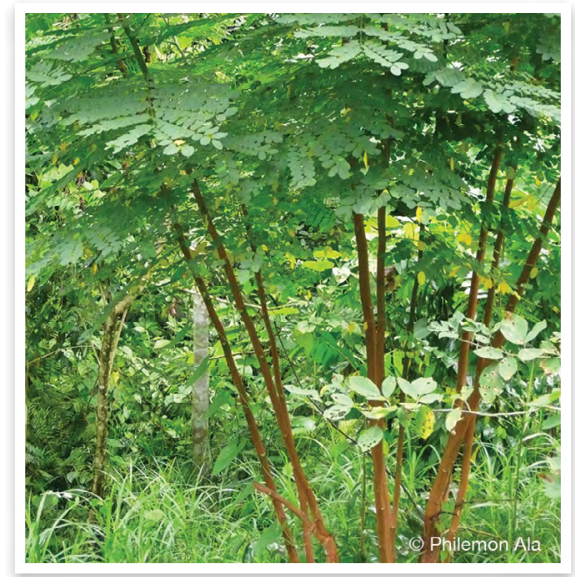

wēwēn Adenanthera pavonina wëvër lo rosewood burao blong solwota Thespesia populnea

winiā̄ soursop karasol Annona muricata

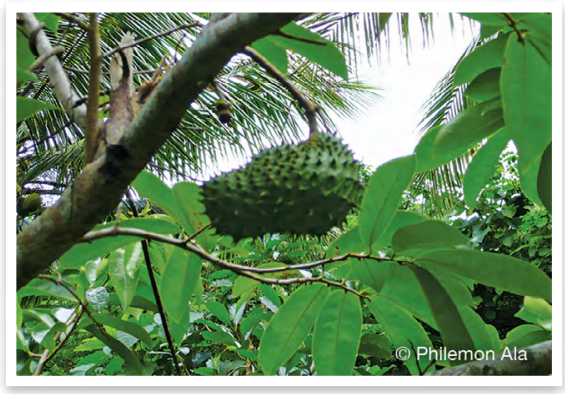

winiā̄ $~$ Annona muricata

woman pawpaw, papaya popo Carica papaya

woro dragon plum nakatambol

Dracontomelon vitiense

wosvet Mossman mahogany, kind of hardwood tree with white flowers and red seeds wan kaen tri we flaoa blong hem i waet mo sid i red Dysoxylum arborescens

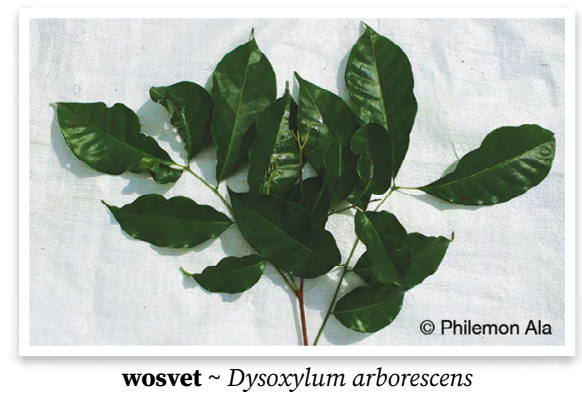

wotag (fr.var. watag) cutnut, bush nut $\sim$ navele Barringtonia edulis

wotag dere timiat kind of cutnut that has dark red leaves and skin of fruit kaen navele we lif mo skin blong kakae blong hem i red olsem blad

wotag dun kind of cutnut kaen navele

wotag sërsër kind of cutnut kaen navele

wotag wos kind of cutnut kaen navele 
wotag wōtōn kind of cutnut kaen navele

wotag wöl kind of cutnut kaen navele

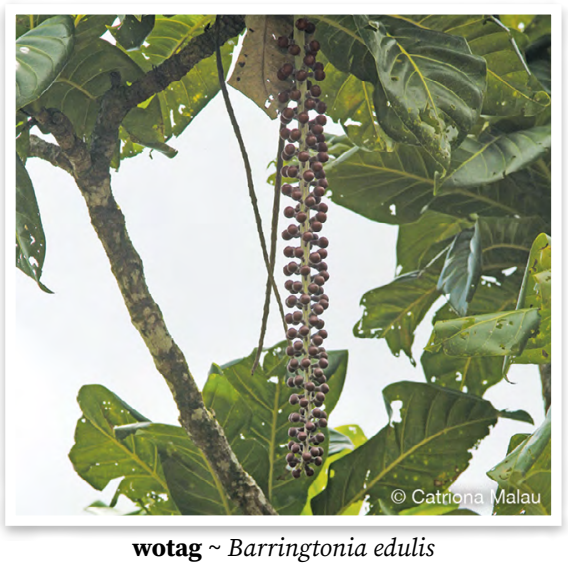

wotag bē kind of tree, of same genus as cutnut, but does not have edible nuts kaen wud we hem i famle blong navele, be yu no save kakae Barringtonia racemosa

wōlōm Indian mulberry noni, yalatri, yalawud Morinda citrifolia

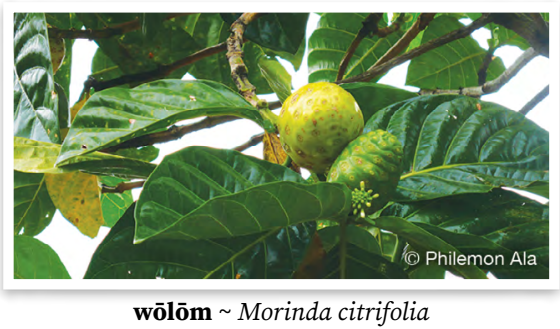

wōnōnōg malgias kind of tree wan kaen tri

wōtōgōrte kind of tree with very long fruit which are sticky like glue. The fruit is green when unripe and red when ripe. The wood is used in house building wan kaen tri we frut blong hem i longlongwan mo i stiki olsem glu. Frut i grin be i kam red taem i raep. Ol i yusum wud blong wokem haos wōtōn kind of fig with round fruits that are dark red when ripe, fruits are eaten by birds wan kaen tri we kakae blong hem i raon mo waet mo i dak red taem i raep mo ol pijin ol i kakae Ficus granatum

wōvōnō kind of shrub, small tree kaen navenue Macaranga dioica

wö kind of tree wan kaen tri Ixora asme

wöbulbulbōk glue berry tree glutri Cordia dichotoma

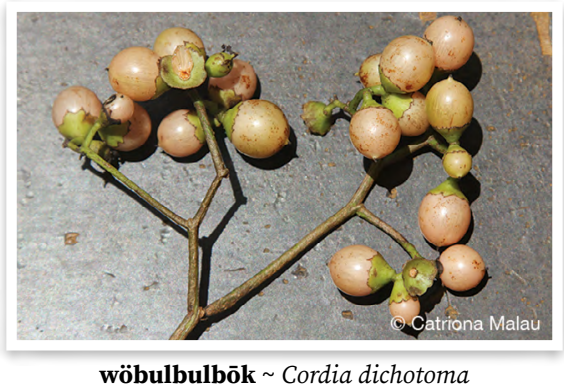

wödödö kind of tree, poison peach wan kaen tri Trema orientalis

wu kind of small tree with hard wood wan kaen tri we hem i strong mo i no save gro bigwan

wuqiat kind of tree whose wood is used as a digging stick for planting taro kaen wud we ol i yusum olsem wud blong planem taro

\section{D1.1 Coconuts}

bar $_{1} 1 \cdot$ mature coconut that has very thin flesh and so is not good for making copra and spongy growth inside is not good for eating kokonas we mit blong hem i tintin tumas, mekem se yu no save mekem kopra long hem $\mathbf{2}$ • (of coconut) has reached stage where the flesh has become thin and spongy growth inside is no longer good for eating (kokonas) i nomo gudfala navara blong kakae mo i nomo gud blong mekem kopra long hem 
bar 2 variety of coconut that has very small fruit that do not have much liquid in them but the liquid is very sweet kaen kokonas we hem i smol tumas be wota blong hem i swit

bes 1 - coconut oil, oily substance lining the flesh of germinated coconuts oel blong kokonas, krim we i stap wetem navara $\mathbf{2}$ - put coconut oil or grease on something, as to heal a sore or grease something rusty putum oel o krim blong kokonas long wan samting olsem long soa o long wan rosta aean

bibiag stage of coconut growth when the flesh is dry but the skin is still green $\sim$ mit blong kokonas i drae be skin blong hem i grin yet

gölörēki 1 - sprouting coconut that is just starting to germinate and has not yet formed spongy growth inside kokonas we i stat blong kam navara be wota i stap insaed yet $\mathbf{2}$ shoot of coconut begins to grow gro blong kokonas i stap kamaot be i no mekem gud navara yet

lovv grated coconut that has had the milk squeezed out of it makas blong kokonas

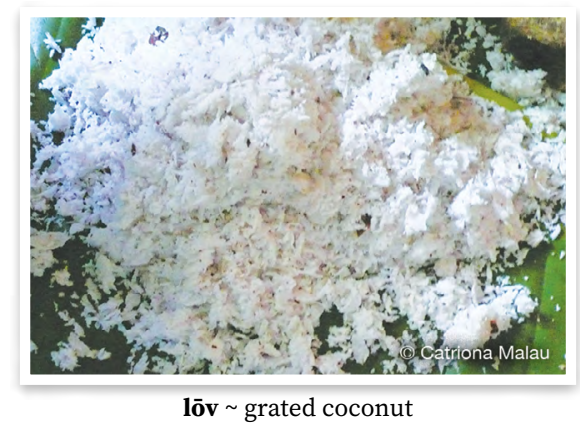

matabōbōt mature coconut $\sim$ drae kokonas

mōtō $1 \cdot$ coconut, generic term for coconut palm, and for fruit when ripe kokonas Cocos nucifera 2 coconut milk melek blong kokonas mōtō atm̄ēn variety of coconut that is characterised by rapid growth but poor productivity kaen kokonas we i gro kwiktaem be i no karem tumas kakae

mōtō bal variety of coconut where two palms grow from one coconut or two are planted side by side kaen kokonas we tu kokonas i gro i kamaot long wan kokonas o we ol i planem tu kokonas i stap klosap tumas

mōtō dēdērēs variety of coconut that has very sweet flesh and water $\sim$ kaen kokonas we kakae mo wota blong hem i swit tumas mōtō elvet variety of coconut which has long fruit kaen kokonas we frut blong hem i longfala

mōtō ga añan̄ variety of coconut that has yellow fruit and yellowish leaves kaen kokonas we frut blong hem i yelo mo lif i lelebet yelo

mōtō ga garaq variety of coconut that is a new hybrid kaen kokonas we i niuwan

mōtō ge metestes variety of coconut which has long fruit kaen kokonas we frut blong hem i longfala

mōtō gō tōtōrōg variety of coconut that has green fruit $\sim$ kaen kokonas we frut blong hem i grin

mōtō gö luwō large variety of coconut with thick meat kaen kokonas we i bigwan mo i gat bigfala kakae

mōtō malgias variety of coconut that has reddish greenish coloured fruit kaen kokonas we frut blong hem i grin red

mōtō mamē variety of coconut that has red fruit $\sim$ kaen kokonas we frut blong hem i red

mōtō mete röwö variety of coconut so called because the eyes on the shell stick out like those of the fish 
röwö kaen kokonas we ol i kolem olsem from ae blong hem i stik aot olsem ae blong wan fis, röwö

mōtō mölumlum variety of coconut that has soft flesh which is thus easy to remove from the shell kaen kokonas we kakae i sofsof mo i isi blong salem

mōtō mat variety of coconut that has stripes encircling the fruit kaen kokonas we $i$ gat ol straep i raonem frut

mōtō reqe variety of coconut that is characterised by slow growth yet high productivity kaen kokonas we i gro sloslo be i karem plante kakae mōtō sā̄sam variety of coconut which has long fruit kaen kokonas we frut blong hem i longfala

mōtō seseser variety of coconut that is easily husked kaen kokonas we $\mathrm{i}$ isi blong karemaot skin blong hem mōtō sial me variety of coconut that was introduced from another island kaen kokonas we i kam long narafala aelan

mōtō silat variety of coconut that has fragile leaves and inflorescences and is not highly productive $~$ kaen kokonas we lif mo flaoa blong hem i no strong mo hem i no karem tumas kakae

mōtō taktak variety of coconut kaen kokonas

mōtō us variety of coconut with flesh that is sweet and soft with lots of liquid kaen kokonas we i swit, i sofsof mo i gat plante wota

mōtō vanvan variety of coconut kaen kokonas

mōtō vet variety of coconut that has very hard flesh that is thus difficult to remove from shell kaen kokonas we $\mathrm{i}$ strong tumas mo i had blong selaot mōtō vin gaqō variety of coconut with a thick husk kaen kokonas we skin blong hem i tik

mōtō wulmē variety of coconut that has a reddish coloured ring surrounding where the peduncle is attached to the fruit $\sim$ kaen kokonas we $i$ gat red ring long frut long ples we i joen long han

mël green coconut that has no flesh on the shell, but has water inside, although the liquid is not sweet yet $\sim$ grin kokonas we hem i gat wota blong hem be i nogat mit mo yumi no stap dring from i no swit tumas

n̄ēnēn $\mathbf{1}$ • (shoot) start to emerge from coconut $\sim$ gro i stat blong kamaot long kokonas 2 • newly emerging coconut shoot $\sim$ gro blong kokonas

qōtō ${ }_{1}$ semi-mature coconut, which has fizzy liquid inside haf drae kokonas we wota insaed long hem i gat gas long hem

qōtōnögōsōw empty full shell of mature coconut that has not germinated and the husk and albumen inside have decomposed $\sim$ drae kokonas we hem i no kam navara mo skin mo kakae blong hem insaed i lus

sōgsōg ${ }_{1}$ variety of coconut that bears a large number of small fruit which have sweet liquid inside kaen kokonas we i karem fulap frut we ol i smolsmol mo wota blong hem i swit sōl young coconut seedling, general term for germinated coconut navara

sōlvet young coconut seedling that is firm and sweet navara we $i$ strong mo i swit

sōl kētkèt coconut that has germinated while still hanging to the tree, which has very sweet flesh $\sim$ kokonas we i kam navara taem i 
stap hang yet long stamba mo i no foldaon hem wan, navara blong hem i swit tumas

tur mōtō coconut palm stamba blong kokonas

vinkörögör coconut shell that has had flesh removed $\sim$ sel kokonas

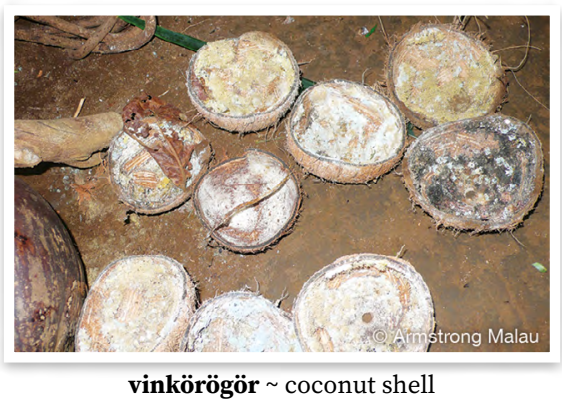

vinlas coconut shell with flesh removed, especially when used as a cup for drinking kava sel kokonas, olsem ol i dring kava long hem

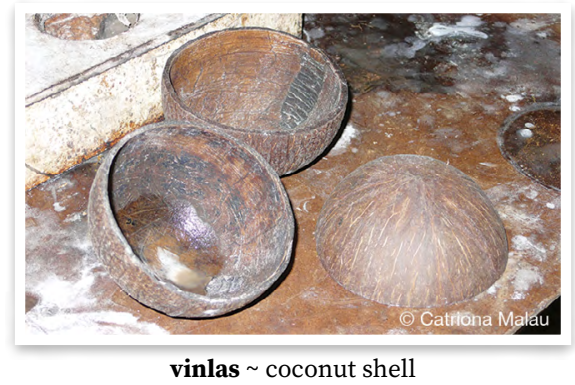

vōs green coconut grin kokonas

vōs gargarteqërët green coconut at beginning of stage appropriate for drinking, with soft shell, thin flesh and liquid inside $\sim$ grin kokonas we sel blong hem i sofsof, kakae blong hem $\mathrm{i}$ tintin mo i gat wota blong hem webeges coconut spathe (leafy sheath that encloses spadix (cluster of flowers)) samting olsem lif we $\mathrm{i}$ kavremap bandel blong flaoa blong kokonas wēlēwlēw coconut spadix (plant spike bearing flowers) samting blong kokonas we ol flaoa i stap gro long hem

wēsustēgēr dry coconut that does not contain any liquid inside $\sim$ drae kokonas we i nomo gat wota i stap long hem

wiqian young coconut seedling with a small haustorium (the spongy embryo that grows inside when the coconut is germinating) navara we insaed blong hem i smol nomo

\section{D1.2 Breadfruit}

bēw $_{2}$ variety of breadfruit kaen bredfrut

biēg ge mirmiar variety of breadfruit that has small fruit $\sim$ kaen bredfrut we kakae blong hem i smolwan

biēg löt variety of breadfruit that is good for making löt as it is neither too hard nor too soft kaen bredfrut we hem i gud blong nalot from hem i no sofsof tumas mo i no had tumas

biēg ta motlav variety of breadfruit that is good for boiling kaen bredfrut we hem i gud blong kuk

dēmēl variety of breadfruit that has elongated fruit $\sim$ kaen bredfrut we kakae blong hem i longwan

dōwōn variety of breadfruit that has small fruit kaen bredfrut we kakae blong hem i smolwan

döbumsër variety of breadfruit that has small fruit kaen bredfrut we kakae blong hem i smolwan

gatege variety of breadfruit that has small fruit kaen bredfrut we kakae blong hem i smolwan

gole variety of breadfruit that has elongated fruit $\sim$ kaen bredfrut we kakae blong hem i longwan

mëtëwtëw ev variety of breadfruit that cooks quickly kaen bredfrut we $i$ dan kwiktaem 
mereg variety of breadfruit that has small fruit kaen bredfrut we kakae blong hem i smolwan

nere ak variety of breadfruit kaen bredfrut

pispol variety of breadfruit that has large fruit kaen bredfrut we kakae blong hem i bigwan

qalmiat variety of breadfruit kaen bredfrut

qötuq $\overline{\mathbf{o}}_{1}$ variety of breadfruit that has large fruit kaen bredfrut we kakae blong hem i bigwan

selge variety of breadfruit that is good for making löt as it is neither too hard nor too soft $~$ kaen bredfrut we hem i gud blong nalot from hem i no sofsof tumas mo i no had tumas

söw malgias variety of breadfruit kaen bredfrut

söw taban variety of breadfruit $\sim$ kaen bredfrut

tamōt variety of breadfruit that is good for boiling kaen bredfrut we hem i gud blong kuk

tōt vaslēe variety of breadfruit kaen bredfrut

tönödem variety of breadfruit that has large fruit $\sim$ kaen bredfrut we kakae blong hem i bigwan

vinbaw variety of breadfruit $~$ kaen bredfrut

wotasiwōw variety of breadfruit that has elongated fruit $\sim$ kaen bredfrut we kakae blong hem i longwan

\section{D1.3 Bananas}

bakrës variety of banana kaen banana

$\mathbf{b} \overline{\mathbf{e}}_{3}$ variety of banana with very long, large fruit, and the fruit must be squeezed to enable peeling kaen banana we kakae blong hem i longlongfala mo i bigwan, mo yu mas skwisim bifo yu pilim

brisben variety of banana kaen banana ëtëtlam variety of banana that has a very tall trunk with small fruit growing in a long bunch kaen banana we stamba blong hem i gro hae bitim ol banana, kakae blong hem i smolsmol mo bandel i longfala

kukuög variety of banana that is only eaten ripe, not cooked when unripe, the fruit will fall off when you shake the trunk kaen banana we ol i kakae raepwan nomo mo taem yu sekem stamba ol raepwan i foldaon, mo hem i sotfala

lian manu variety of banana kaen banana

male $_{2}$ variety of banana that has roundish fruit, white flesh and does not have a strong flavour. The banana bundle grows upwards rather than hanging down $\sim$ kaen banana we kakae blong hem i raon mo i waet insaed be i nogat tumas tes. I sakem kakae blong hem i go antap

matmat malgias variety of banana that has whitish fruit, leaves and trunk, with long, large fruit $~$ kaen banana we skin mo stamba mo lif blong hem i waet mo hem i bigwan

matmat mamē variety of banana that has reddish fruit, leaves and trunk, with long, large fruit $\sim$ kaen banana we skin mo stamba mo lif blong hem i red

mianisi variety of banana with small, thin, bent fruit and short trunk kaen banana we hem i save gro hae. Tes blong kakae i defren lelebet be i olsem samo

malmalbak variety of banana that has long, large fruit $\sim$ kaen banana we stamba blong hem i bigfala mo hem i gro hae be hem i no karem fulap kakae. Taem ol i kukum i drae we i drae

retekraw variety of banana kaen banana 
rēn̄rēñ variety of banana that appears to be ripe when it is not completely ripe, and will be ripe approximately two days after first appearing to be ripe $~$ kaen banana we i save raep tu taem, hem i luk olsem i raep be yu mas wet, afta tumora bae i raep

rurun̄ög variety of banana that is only eaten ripe, not cooked and eaten when unripe. The fruit will fall from bundle when the trunk is shaken kaen banana we ol i kakae raepwan nomo mo taem yu sekem stamba ol raepwan i foldaon. Hem i sotfala

samo variety of banana with a short trunk and small, thin, bent fruit kaen banana we stamba blong hem i sotfala mo kakae blong hem i smol mo i benben

sēnē variety of banana kaen banana siwit variety of banana kaen banana

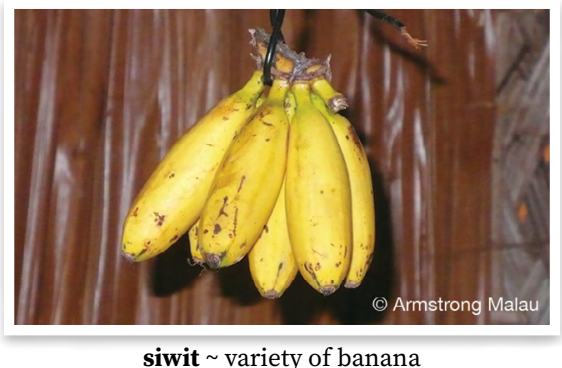

sōbōt variety of banana with small, thin, bent fruit and short trunk kaen banana we kakae blong hem i olsem samo be stamba i sotsotfala

tores variety of banana kaen banana tulug variety of banana, considered to be one of the original endemic varieties on Vanua Lava, with very long fruit, eaten only when ripe, not cooked when unripe kaen banana we kakae blong hem i longlongfala. Hem i blong kakae taem i raep mo yu mas skwisim fastaem

ulēulēi variety of banana kaen banana vagvag variety of banana kaen banana

vetel banana banana Musa spp. vetel mal variety of banana that has a large trunk but small fruit. The bundle can be quite long wan kaen banana we stamba blong hem i bigbigwan be kakae blong hem $i$ smol. Samtaem bandel blong hem i longfala

vetel talisōr variety of banana, traditionally considered one of the original endemic varieties, with red fruit, leaves and trunk wan kaen banana we hem i red, lif i red mo stamba blong hem i smol mo red

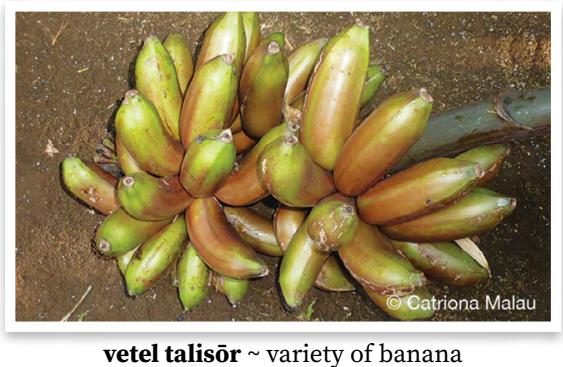

vietnam variety of banana kaen banana

vila variety of banana with long, large fruit kaen banana we kakae blong hem i longfala mo i bigwan

vinwōn variety of banana that is long and a flat shape kaen banana we hem i olsem asis banana be hem i longfala lelebet mo hem i save flat vinwōn ga qag variety of banana kaen banana

vinwōn gō tōtōrōg variety of banana kaen banana

wavagvag variety of banana that has a bundle that grows upwards instead of down. The fruit are roundish and yellow inside with red skin kaen banana we bandel blong hem i gro antap, i no hang daon. Kakae blong 
hem i raon mo taem i raep i red be insaed i yelo. Taem man i kakae i pispis yelo

wēwēsēg variety of banana that has small, short fruit asis banana we hem i raon mo i sotfala

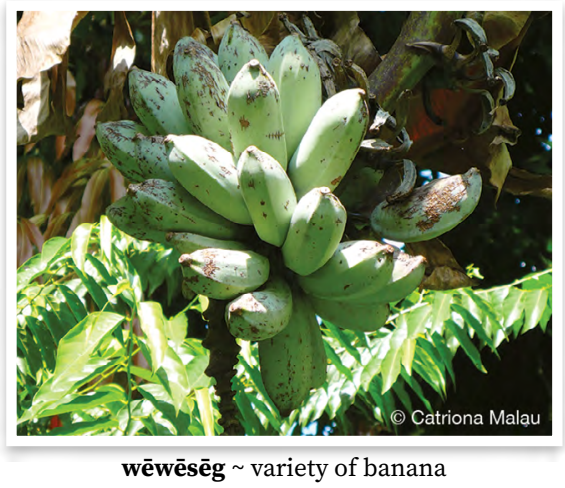

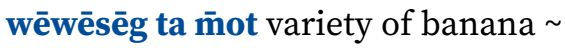
kaen banana

wēwēsēg ta ōrbarbar variety of banana kaen banana

wiriatege variety of banana with very long, large fruit, it has a large trunk but does not bear lots of fruit kaen banana we kakae blong hem i longlongfala mo i bigwan, i gat bigfala stamba be hem i no karem fulap kakae

worwor variety of banana that has long, large fruit and is yellow when ripe kaen banana we samtaem kakae blong hem i no kamaot long en be long medel. Hem i bigwan olsem vila, hem $\mathrm{i}$ grin mo taem $\mathrm{i}$ raep i yelo

\section{D2 Bushes, shrubs}

bēkil kind of shrub wan kaen plant Polyscias samoensis

bormiak evodia, shrub with distinctive, pleasant-smelling leaves, variety with smaller leaves wan kaen lif we i gat naes smel, lif blong hem i bigwan Evodia hortensis

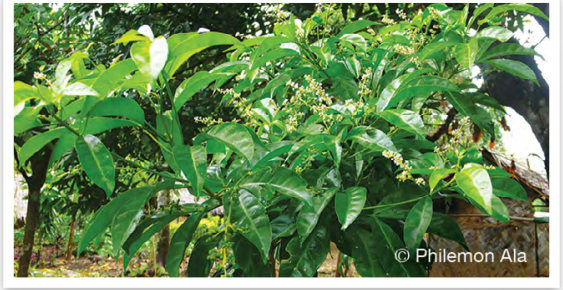

borm̄iak Evodia hortensis

busuqaēn kind of small flowering shrub with white flowers and small fruit that are red when ripe $\sim$ wan kaen wud we $i$ gat waet flaoa, frut blong hem i smolsmol mo i grin be taem i raep i red. Lif blong hem i smolsmol mo stamba i no save gro bigwan Psychotria aneityensis

busuqërët kind of shrub kaen smol wud Ascarina lanceolata

damalalal kind of shrub whose leaves are eaten as greens $\sim$ kaen bus kabis damat heliconia, plant with large leaves that are used to wrap laplap for cooking in stone oven $\sim$ lif laplap Heliconia indica

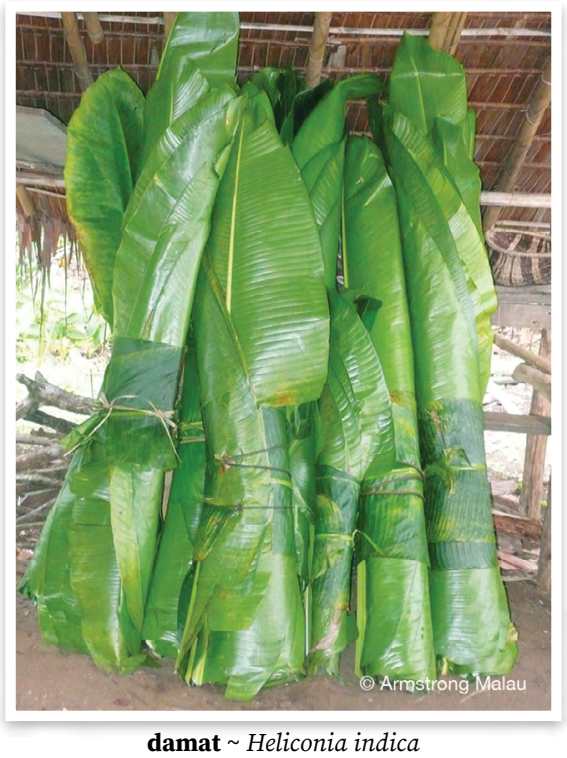

damat dēnin variety of heliconia that has small leaves kaen lif laplap we lif blong hem i smolsmol 
damat möt variety of heliconia which grows wild in the bush and is not cultivated kaen lif laplap we i gro long bus nomo

datamal caricature plant, kind of shrub with edible leaves $\sim$ wan kaen lif we yumi save kukum mo kakae Graptophyllum pictum

datamal an kind of shrub with edible leaves eaten as greens $\sim$ kaen bus kabis

datamiar small shrub with succulent stem and pale purple flowers $\sim$ wan kaen plant we flaoa blong hem i laet popel Coleus scutellarioides

datartarawöw bandicoot berry, kind of shrub with small round black fruit wan kaen plant we smol frut blong hem i raon mo i blak Leea indica

davaqal kind of edible fern that grows in the water or swamp wan kaen bus kabis we $\mathrm{i}$ olsem fens be $\mathrm{i}$ gro long wota o swam Pteris sp.

davarteker kind of shrub, grows to about 2 metres with tiny white flowers wan kaen plant we i gat smolsmol waet flaoa Maesa sp.

deben tenēnēg kind of small plant $\sim$ wan kaen smol plant Melicytus ramiflorus

degetget kind of shrub with leaves which are eaten as greens $\sim$ kaen bus kabis

demen mav kind of shrub wan kaen plant Ficus septica

deteqeñtōw kind of edible fern that grows on hill bus kabis we hem i gro long saed blong hil Pteris sp.

detewel kind of edible fern that grows in the water or swamp kaen bus kabis we i olsem fens be i gro long wota o swam Pteris sp.

dēwērēt aibika variety with reddish stems and veins of leaf $\sim$ kaen aelan kabis we i gat red han blong hem Abelmoschus manihot variety dëmēl ming aralia, kind of plant with edible leaves, that are yellowish green $~$ nalaslas, wan kaen tri we lif blong hem i gat ol poenpoen long saed blong hem Polyscias fruticosa, Polyscias guilfoylei

dimililial kind of shrub whose leaves are eaten as greens $\sim$ kaen bus kabis dimia kind of shrub, native mulberry $\sim$ wan kaen plant Pipturus argenteus

dimiarēsul aibika variety with lots of branches, eaten as greens $\sim$ kaen aelan kabis we i gat fulap han long hem Abelmoschus manihot variety

ditial ${ }_{1}$ kind of shrub wan kaen plant Selaginella durvillei

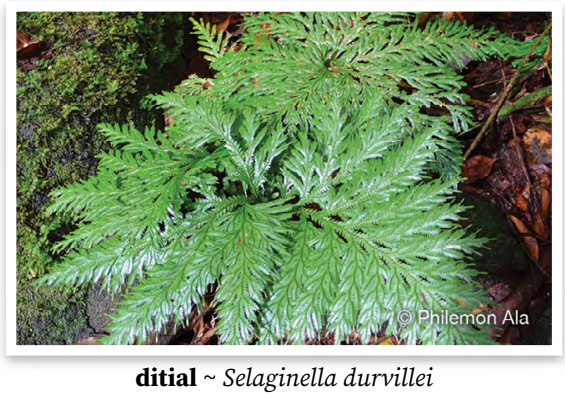

dōrōt type of edible fern bus kabis, kaen fens we yumi save kakae Diplazium harpeoides

dömöwön variety of caricature plant, kind of shrub with edible leaves kaen bus kabis

dövuln̄ö dinner plate aralia, kind of plant with edible leaves nalaslas Polyscias scutellaria

dunrē̄ēlēg kind of plant, shrub wan kaen wud Leucosyke australis

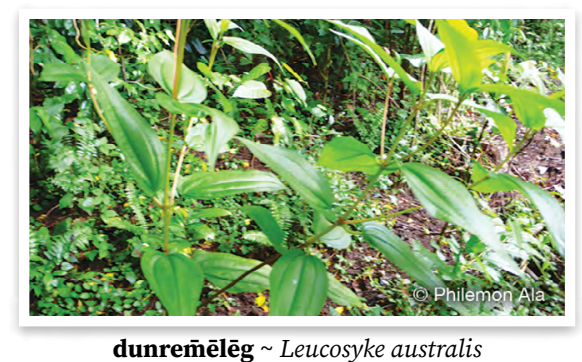


duturkulo (fr.var. döturkulo) variety of aibika, shrub with leaves that are commonly eaten as vegetable greens $\sim$ kaen aelan kabis Abelmoschus manihot variety

galō silver croton wan kaen tri Croton insularis

garmēbuluk variety of aibika, shrub with leaves which are commonly eaten as vegetable greens kaen aelan kabis Abelmoschus manihot variety

kirkiar croton kala lif Codiaeum variegatum

kirkiar mamēgin variety of croton that grows in the bush and is not planted near houses wan kaen kala lif we i stap long bus nomo

kirkiar meter variety of croton wan kaen kala lif

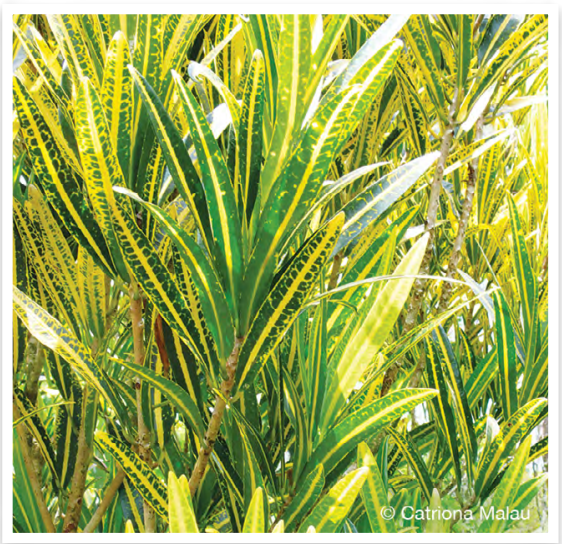

kirkiar meter variety of croton

kirkiar qere q⿳亠丷厂 variety of croton with curly leaves wan kaen kala lif we lif blong hem i tantanem

kirkiar qet variety of croton that is red and green $\sim$ wan kaen kala lif we i red mo grin

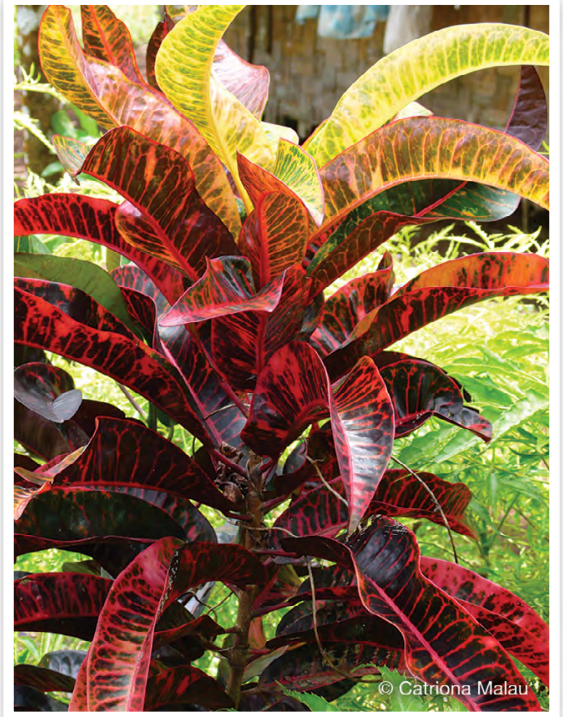

kirkiar qet $\sim$ variety of croton

kirkiar sas qön variety of croton wan kaen kala lif

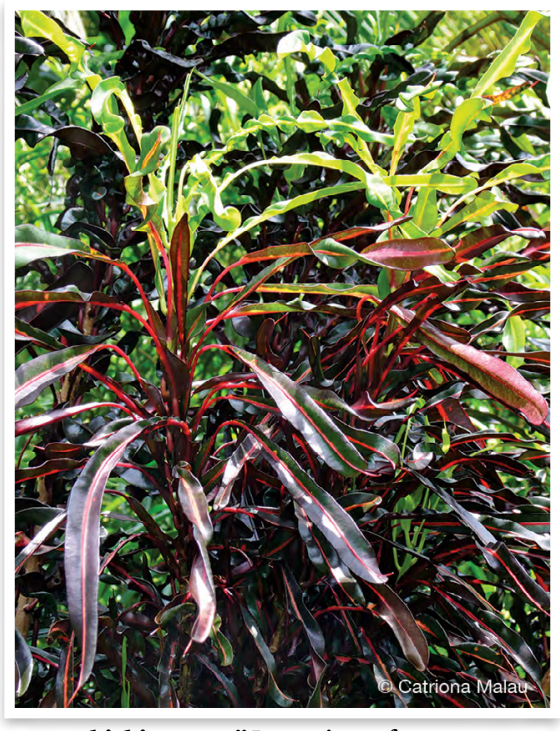

kirkiar sas qȫ̄ $~$ variety of croton

qēqūl mangrove natongtong Rhizophora spp.

qōmur (fr.var. dōqōmur) kind of shrub kaen plant 
rēwēsil variety of aibika, shrub with leaves which are commonly eaten as vegetable greens kaen aelan kabis Abelmoschus manihot variety

$\operatorname{sasar}_{1} \mathbf{1} \cdot$ aibika, kind of shrub that is planted for leaves that are eaten as greens aelan kabis Abelmoschus manihot $\mathbf{2}$ - greens, generic term for leaves that are eaten as greens, whether planted as a crop or gathered from wild plants aelan kabis, nem i kavremap ol defren kaen kabis

seg evodia, shrub with distinctive, pleasant-smelling leaves, variety with wider, larger leaves wan kaen lif we i gat naes smel, lif blong hem i bigwan Evodia hortensis

sör nicolaia; plant from the ginger family which has nice-smelling leaves, used as decoration for dancing and in the house kaen lif we hem i famle blong jinja, i gat naesfala smel blong hem mo ol i yusum long danis olsem dekoresen Hornstedtia sp.

tutugēn tamarge kind of small shrub with purple flowers wan kaen plant we i gat flaoa we i popel Blumea lacinuata

vōnōdöwö kind of shrub, with furry leaves and stem and small mauve flowers wan kaen smol plant Ageratum conyzioides

waqagal hibiscus haebiskas Hibiscus rosa-sinensis

waran̄rañ kind of shrub wan kaen tri Acalypha spp.

waran̄rañ ga qag plant with pale leaves kaen plant we lif blong hem i waet Acalypha forsteriana

waran̄rañ mamē plant with red leaves kaen plant we lif blong hem i red Acalypha hispida wōlōlōmeren kind of flowering plant with long shiny leaves and orange flowers kaen plant we hem i gat longfala lif we i saen mo flaoa blong hem i dak yelo Oxera vanuatuensis

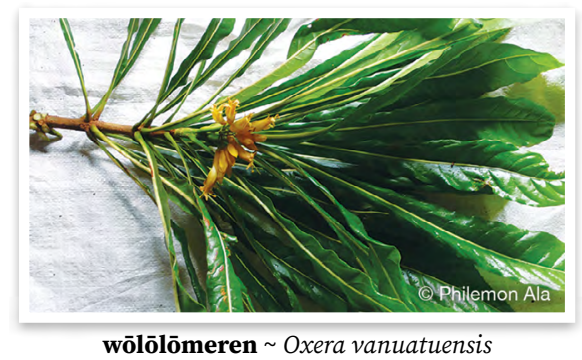

wōvōt kind of shrub, with fruit that is red when ripe wan kaen tri we i no bigwan be kakae blong hem i bigfala. Sep blong kakae i olsem nakavika mo $i$ grin be taem i raep $i$ red. Flaoa blong hem i waet Phaleria sp.

wösusurbē kind of shrub with round, bright orange fruit wan kaen tri we kakae blong hem i grin mo taem i raep $i$ aranis-red Tabernaemontana sanguinea

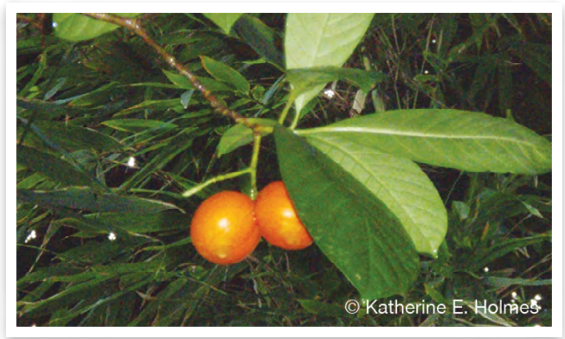

wösusurbē $\sim$ Tabernaemontana sanguinea

D3 Grasses, bamboo, vines

bō 1 - length of bamboo used for carrying water bambu blong fulumap wota 2 - length of bamboo used for making beat in dance bambu blong kilim long wud long taem blong danis

dañdan̄ sugarcane variety kaen sugaken 
ditial ${ }_{2}$ kind of grass with tiny white flowers wan kaen gras we i gat smolsmol waet flaoa

diwinwian kind of plant kaen lif Freycinetia tannaensis

do kind of vine $\sim$ wan kaen rop

do man kind of leaf from a vine that is used to poison fish wan kaen kastom lif blong wan rop we yu yusum blong posenem fish Derris elegans

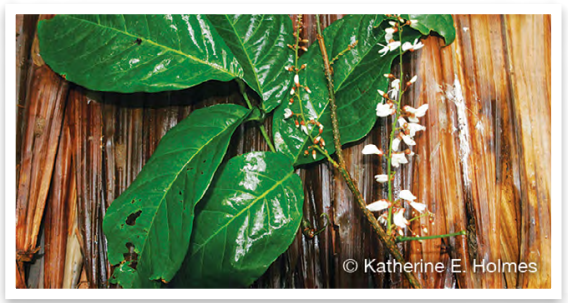

do man Derris elegans

do qōrgavgav leaf that looks like do man, which is used to poison fish, but do qörgavgav is not poisonous wan lif we i luk olsem do man be i nogat paoa blong posenem fis

dōsōwtöl kind of vine, ground creeper with purple flowers wan kaen rop we flaoa blong hem i popel Canavalia rosea

ga $_{1} \mathbf{1} \cdot$ vine $\sim$ rop

ga atat (fr.var. ga qir) climbing canelike vine $\sim$ wan rop we ol i yusum blong fasem haos Flagellaria indica

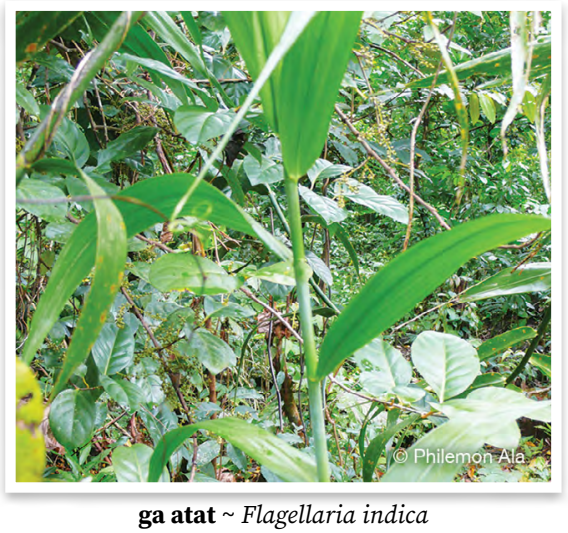

ga del kind of large leaved vine that grows up and wraps around trees $\sim$ wan kaen rop we i gro antap long wud we lif blong hem i bigwan Epipremnum pinnatum

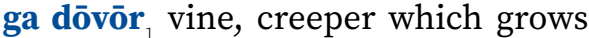
on beach, seashore wan kaen rop we i stap gro long sanbij mo klosap long solwota Ipomoea pes-caprae

ga iaw kind of vine wan kaen rop Anodendron paniculata

ga matawase kind of vine that grows straight and is white when immature and light brown when mature $\sim$ wan kaen rop we hem i smol nomo mo i save gro stret. Taem i yang i waet mo hem i kam laet braon Stephania forsteri

ga mien kind of vine $\sim$ wan kaen rop Epiprenum sp.

ga ōl kind of vine wan kaen rop

ga sasinirnir kind of vine wan kaen rop Cayratia trifolia

ga susul morning glory; kind of vine with blue flowers wan kaen smolsmol rop we i gro long garen mo long haos be no long bus Ipomoea acuminata

ga taqav kind of vine with large leaves wan kaen rop we lif blong hem i bigwan Merremia peltata

ga töus kind of vine which bears tubers similar to sweet potato $\sim$ wan kaen rop we i gat kakae blong hem olsem kumala

ga vörur kind of vine snek rop

gakalkalbōgō jackbean; kind of flowering vine $\sim$ wan kaen rop Canavalia cathartica

gakarēs kind of climbing fern wan kaen rope Lygodium reticulatum

gamalwuw kind of black vine wan kaen rop we i stap long bus mo hem i blak Smilax vitiensis

gamērēr kind of vine wan kaen rop Freycinetia spp. 
gamērēr dēmadēm kind of vine wan kaen rop Freycinetia flavida

gamērēr qō kind of vine wan kaen rop Freycinetia impavida

gatōw kind of strong vine that grows on hills and by the sea but not in the bush. It is hard but can be easily broken when immature wan kaen rop we i stap long hil mo long solwota be no long bus. I strong be yangwan i save brok isi Derris trifoliata

gatöus kind of vine that has fruit which is eaten in time of famine. It is very sour tasting wan kaen rop we ol i kakae frut blong hem long taem blong famin. Hem i konkon mo i saoa

gawol lawyer cane, rattan $\sim$ loeaken Calamus vanuatuensis

mēlēslēs ${ }_{2}$ kind of flowering plant in the nettle family $\sim$ kaen plant Elatostema macrophyllum

mēlēslēs lav kind of flowering plant in the nettle family kaen plant Elatostema beccadi

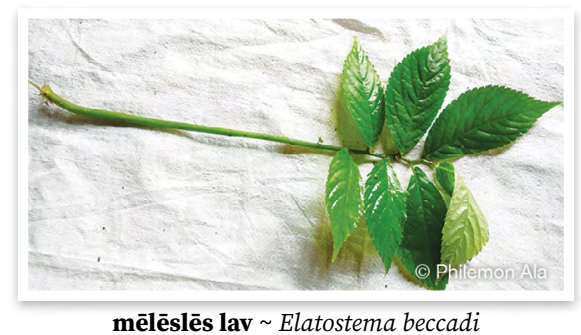

masēlasēl Job's tears; grain-bearing plant wan kaen gras we i longfala mo $i$ gat sid blong hem we i waet mo i strong mo ol i yusum olsem bid Coix lacryma

$\overline{\mathbf{m}} \mathbf{o} \mathbf{g} \mathbf{t}_{1}$ kind of grass wan kaen gras Oplismenus hirtellus

qörö gōsōw kind of vine that grows along the ground wan kaen rop $\mathrm{i}$ gro long graon nomo Geophyla repens rartan wild cane $\sim$ wael ken Miscanthus sp. röv vine used in weaving bird trap rop we ol i yusum blong wivim trap blong pijin

töv sugarcane $\sim$ sugaken Saccharum officinarum

vēlis grass, weeds gras

vēlis ōlōl false dodder, love vine, kind of slender rambling vine that grows on ground wan kaen rop we i gro long graon Cassytha filiformis

waga $_{2} \mathbf{1}$ - passionfruit pasenfrut Passiflora edulis

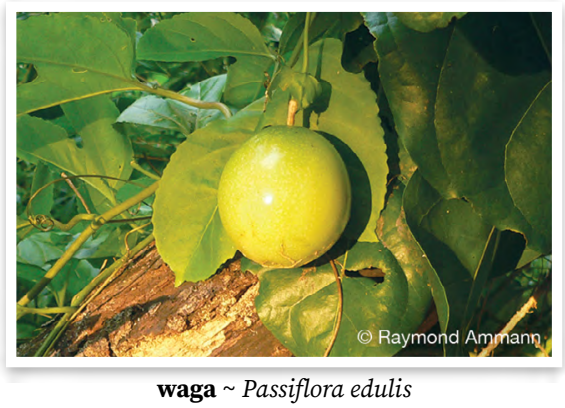

2 - stinking passionflower wael pasenfrut Passiflora foetida

wetelwa kind of vine, similar to a pumpkin with round fruit, the leaves are eaten as greens $~$ kaen rop we yumi save kakae top blong hem

wēnēn bulëvu (fr.var. winin bulëvu) perennial herb with branched cane-like stems kaen flaoa Donax cannaeformis

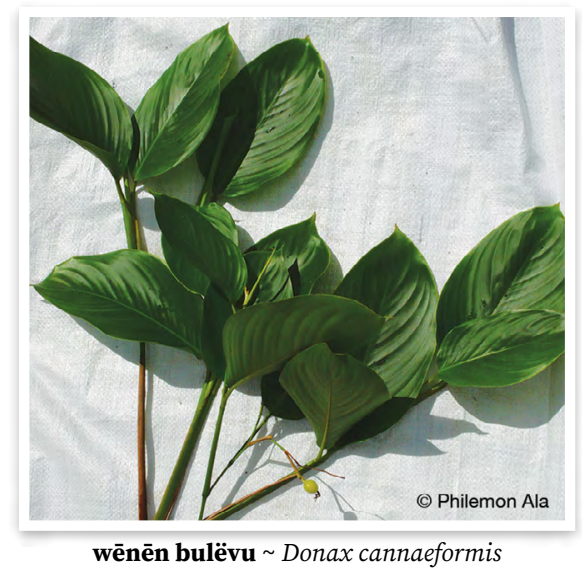


wētēvtēv kind of grass wan kaen gras Scleria polycarpa

woo bamboo bambu Bambusa spp. woo mölum kind of soft bamboo sofsof bambu Bambusa vulgaris woo vet kind of strong bamboo which is thin, long and flexible and bends at the tip strong bambu we i smol be i longfala mo en blong hem i save benben Bambusa sp.

woo vet luwō kind of strong bamboo that is thick and used for wide weaving for house walls strong bambu we i tik mo hem i bigwan blong wivim woling blong haos Bambusa sp.

woo vet nötu kind of strong bamboo that is thin and used for narrow weaving for house walls strong bambu we i smol blong wivim woling blong haos i smolsmol Bambusa sp.

\section{D4 Tubers and roots}

dem (fr.var. dëm) yam yam Dioscorea spp.

dem atat̄̄ēn primary grouping of varieties of yam, yams that bear long tubers ol kaen yam we kakae blong olgeta ol i longlongfala

dem kēlēglēg primary grouping of varieties of yam, yams that bear crooked tubers ol kaen yam we kakae blong olgeta ol i kruked

dem rereqe primary grouping of varieties of yam, yams that bear short tubers ol kaen yam we kakae blong olgeta ol i sotsotfala

kōmar sweet potato kumala Ipomoea batatas

maniok cassava, manioc maniok Manihot esculenta

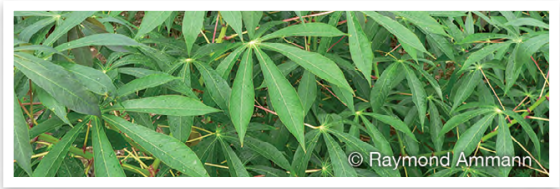

maniok Manihot esculenta qiat taro taro Araceae spp.

qiat atm̄ēn taro grouping, varieties of taro which are 'male' and don't fork grup blong ol taro, man taro we hem i no save karem fok

qiat reqe taro grouping, varieties of taro which can fork grup blong ol woman taro we ol i save karem fok

diqiat taro leaf, cooked and eaten as greens $\sim$ lif blong taro

sinsa ginger $\sim$ jinja

tamag lesser yam, Chinese yam wovile, swityam Dioscorea esculenta $\mathbf{v} \overline{\mathbf{e}}_{1}$ giant taro, elephant ear taro waeltaro Alocasia macrorrhiza

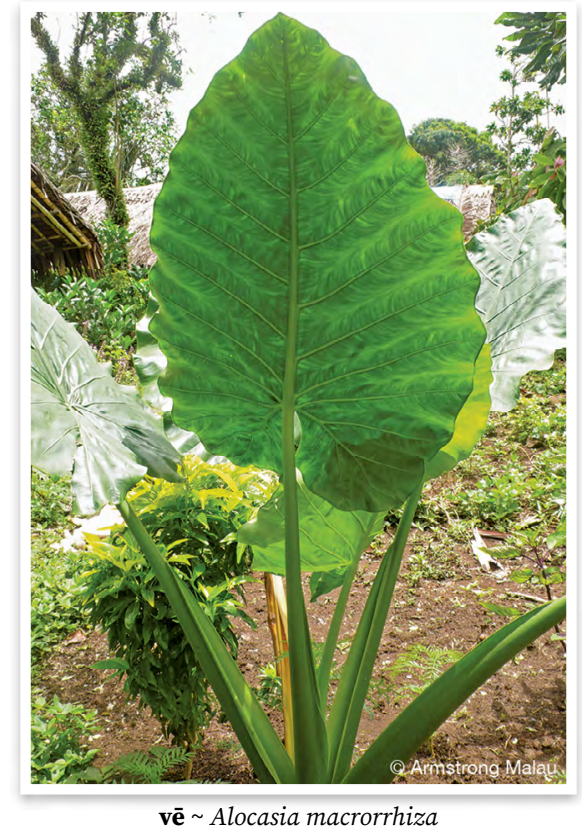

waan turmeric kari jinja Curcuma longa

\section{D4.1 Taro}

akrikalja variety of taro, 'male', which occurs in a variety of colours and shapes $\sim$ kaen taro

biliag $_{3}$ variety of taro, 'female', a type of marē, with a dark red stem kaen mare taro we hem i woman we han blong hem i dak red 
böl variety of taro, an old variety with a whitish stem that is no longer planted kaen taro blong bifo we ol i nomo planem we han blong hem i waet

bulalēv variety of taro, 'male', with a black stem kaen taro we hem i man we han blong hem i blak

burmatan variety of taro, 'male', with a dark green bottom, dark purple top and black petiole $~$ kaen taro we hem i man we han blong hem i dak grin daon mo antap i dak popel

busuōr variety of taro, 'female', with light red stem and top with light green stripes $\sim$ kaen taro we hem $i$ woman we han blong hem i laet red wetem grin straep long hem

din̄venqiat variety of taro, 'female', with a stem that is whitish at the bottom and light green at the top kaen taro we hem i woman we han blong hem i waet daon mo i grin antap

dogon variety of taro kaen taro

ërmamē variety of taro, with a light red stem with white stripes $\sim$ kaen taro we han blong hem $\mathrm{i}$ laet red mo i gat waet straep

galatentur variety of taro that has white tuber, skin and stem kaen taro we hem i waet evriwan, kakae wetem han mo skin tu i haf waet

götö variety of taro, 'male', with black stem, and white corm with red spots $\sim$ kaen taro we hem i man we han blong hem i blak mo kakae blong hem i waet wetem red spot

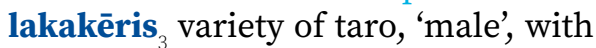
light green stem kaen taro we hem i man we han blong hem i laet grin

lantar variety of taro, 'female', with two types $\sim$ kaen taro we hem i woman mo hem i gat tu kaen blong hem lantar lamkör variety of taro, 'female', with black stem kaen taro we hem i wan kaen lantar. Han blong hem i dak mo kakae blong hem i waet

lantar malgias variety of taro, 'female', one of the largest tubers with a soft corm, stem is purple with light green at top kaen taro we hem i wan kaen blong lantar. Han blong hem i laet gre mo kakae blong hem i waet

len̄man variety of taro, 'female', with green stem with white or yellow stripes $\sim$ kaen taro we hem i woman we $\mathrm{i}$ gat grin han wetem waet o yelo straep long hem

lomonwer variety of taro with light green stem and yellow corm $\sim$ kaen taro we han blong hem i laet grin mo kakae blong hem i yelo

lōkreg variety of taro, 'female', with brown stem with light green stripes, and white corm kaen taro we han blong hem i laet braon mo kakae i waet. Hem i strong lelebet mo hem $i$ save karem fok

lōkreg mamē variety of taro, 'female', with red stem $\sim$ kaen taro we hem $i$ woman we han blong hem i red

mako variety of taro, 'male', with stem that is red at bottom and green at top $\sim$ kaen taro we hem i man we han blong hem i red daon mo grin antap

malmalei lantar variety of taro, 'male', family of lantar, with many stems that are dark green at bottom and light green at top, and small corms that are covered in roots and rot easily kaen taro we hem i man mo hem i famle lantar, we kakae blong hem i gat fulap rus blong hem mo $\mathrm{i}$ save roten isi. Han blong hem i dak grin daon mo i laet grin antap manreva variety of taro $\sim$ kaen taro 
mare $\bar{e}_{2}$ grouping of kinds of taro that don't fork but grow tall and crooked grup blong ol kaen taro we ol i no save karem fok be ol i save longfala mo benben (olsem namarae)

marē wasalav variety of taro, 'male' with stem that is white at bottom and light brown at top, with light black petiole kaen taro we hem i no save gro bigwan be i save longfala. Hem i sofsof nomo mo kakae i waet

marē wasalav mamē variety of taro, 'male', with red stem and white corm kaen taro we hem i man we han blong hem i red mo kakae blong hem i waet

masta variety of taro, with white stem that is red at bottom kaen taro we han blong hem i waet mo i red daon mensēkē variety of taro, 'male', family of lantar, with many stems that are dark green at bottom and light green at top, and small corms that are covered in roots and rot easily $\sim$ kaen taro we hem i man, we hem i famle lantar, we han blong hem i dak grin daon mo laet grin antap. Kakae blong hem i smol mo i gat fulap rus mo i save roten isi

mesmame $\bar{e}_{2}$ variety of taro, 'female', with red stem $\sim$ kaen taro we hem i woman mo stem blong hem i red

mesvōlōvōl variety of taro, 'female', with green stem kaen taro we hem i woman, we han blong hem i grin

mōlkēl variety of taro, 'female', stem with dark green bottom and dark purple top kaen taro we hem i woman mo stem blong hem i dak grin daon, popel antap

matēkmëgërsurletes variety of taro, 'female', with black stem and yellow corm kaen taro we hem i woman, we han blong hem i dak lelebet mo kakae blong hem i ful yelo merlav variety of taro, with tall dark red stem, and large light red corm $\sim$ kaen taro we stem blong hem i longfala mo i dak red, kakae blong hem i laet red

mēvinvian 2 variety of taro, 'female', with light green stem with light red stripes and light red corm kaen taro we hem i woman, we han blong hem i laet grin wetem laet red straep mo kakae blong hem i laet red

mēw variety of taro, 'female', with purple stem and wavy leaves with black veins on underside $\sim$ kaen taro we hem i woman we han blong hem i popel mo lif i gat blak laen long andanit blong hem

mōvōl variety of taro, 'female', with light purple stem, round leaves kaen taro, we hem i woman, stem i laet popel mo lif i raon

nalumlum variety of taro, 'male', with black stem with stripes $~$ kaen taro, we hem i man, wetem blak stem we i gat straep long hem

nōvōk variety of taro, 'male', with tall brown stem $\sim$ kaen taro, we hem i man, we stem blong hem i longfala mo i braon

ōrbarbar variety of taro, 'female' kaen taro we hem i woman

qiat taro taro Araceae spp.

diqiat taro leaf, cooked and eaten as greens $\sim$ lif blong taro

qiat atm̄ēn taro grouping, varieties of taro which are 'male' and don't fork grup blong ol taro, man taro we hem i no save karem fok

qiat gōl variety of marē taro, 'male', with light green stem and white corm kaen marē taro we hem i man mo i laet bitim evri taro. Hem i save bigwan smol mo hem i save longfala. Han blong hem i laet grin mo kakae i waet 
qiat lēlē variety of taro, 'female', that is considered to be the king of taros as it grows very tall, has a light green stem and white corm kaen taro we han blong hem i laet grin mo kakae i waet. Hem i save bigwan mo longlongfala, hem i king taro

qiat mingala variety of taro, 'female', with light green stem $\sim$ kaen taro we hem i woman, we han blong hem i laet grin

qiat minwog variety of taro, 'female', that is considered to be the king of taros as it grows very tall, has a light green stem and white corm kaen taro we hem i woman, han blong hem i laet grin mo kakae i waet. Hem i save bigwan mo longlongfala, hem i king taro

qiat qet variety of taro, 'female', with black stem and red corm $\sim$ kaen taro we hem i woman, han blong hem i blak mo kakae blong hem i red

qiat qön variety of taro, 'female', with black stem and red corm kaen taro we hem i woman, han blong hem i blak mo kakae blong hem i red

qiat reqe taro grouping, varieties of taro which can fork grup blong ol woman taro we ol i save karem fok

qiat rev variety of taro, a grouping that includes 'male' and 'female' varieties, all have many runners, there is variation in colour and shape grup taro we $\mathrm{i}$ gat plante kaen long hem, we sam i man, sam i woman, i gat defren kala mo sep be evriwan i gat fulap saka

qötuq $\overline{\mathbf{o}}_{2}$ variety of taro, 'male', with black stem with white stripes kaen taro we hem i man, we han blong hem i blak wetem waet straep

regeltëv variety of taro kaen taro rēgēt variety of taro, 'male', with light green stem and small red top $\sim$ kaen taro we hem i man we han blong hem i laet grin mo i red antap

rēlēgtēl variety of taro, 'female', with stem that is red at the bottom and purple at the top $\sim$ kaen taro we hem $\mathrm{i}$ woman mo han blong hem i dak lelebet mo kakae i waet. Skin blong hem i laet grin mo hem i save bigbigfala

rēsim variety of taro, with red stem and light red corm. It is not strong and cannot fork kaen taro we han blong hem i red mo kakae i miks red wetem waet. Hem i no strong mo hem i no save karem fok

rēwurveg variety of taro, 'female', with light brown stem and many roots on the corm $\sim$ kaen taro we hem i woman we han blong hem i laet braon mo kakae blong hem i gat fulap rus long hem

$\mathbf{r o v}_{2}$ variety of taro, 'female', with white stem and corm and red veins under the leaf, and can fork kaen taro we han blong hem $\mathrm{i}$ waet mo kakae blong hem i waet mo hem i save karem fok

rōvōl variety of taro, 'female' with stem that is white at bottom and red at top, with red veins under leaves $\sim$ kaen taro we hem i woman we han blong hem i waet daon mo red antap, mo i gat red mak long lif blong hem

römöwuler variety of taro, 'female', with very dark red stem $\sim$ kaen taro we hem i woman we han blong hem i dak red

sarē variety of taro, 'male', with stem that is white with a small amount of red $\sim$ kaen taro we han blong hem i waet wetem smol red, kakae blong hem i waet mo hem i no save karem fok

sēlēgtel variety of taro kaen taro 
sēstañ variety of taro, 'male', with a tall light green stem with red stripes $\sim$ kaen taro we hem i man, we han blong hem i laet grin mo i gat red straep long hem

siag gēgēt ${ }_{2}$ variety of taro, 'female', with light red stem with white stripes kaen taro we hem i woman we han blong hem i laet red wetem waet straep

sinag $\mathbf{1} \cdot$ taro $\sim \operatorname{taro} \mathbf{2} \cdot$ food $\sim$ kakae

siritimiat variety of taro, 'male', in mare grouping with dark stem, black petiole and red and white corm kaen mare taro we hem i no save bigwan be i save longfala mo i save benben. Han blong hem i dak popel mo kakae blong hem i miks laet red wetem waet. Hem i sofsof mo hem i taro blong rus we i save dan kwik

susdenlē variety of taro with red stem with white stripes kaen taro we han blong hem i red wetem waet straep

suwbē variety of taro, 'female', with white stem and corm. They are big and long and can be crooked like marē taro kaen taro we hem i woman mo han, skin mo kakae blong hem i waet. Hem i longfala mo bigfala mo hem i save ben olsem marē

taltal variety of taro, 'female', with black stem and light spots on leaves $\sim$ kaen taro we hem i woman, we han blong hem i haf dak mo han mo lif $\mathrm{i}$ gat waet spot. Kakae blong hem i waet mo hem i no stap karem fok

tana variety of taro, 'female', with dark red stem $\sim$ kaen taro we hem i woman, we han blong hem i dak red tan̄evsōs variety of taro, 'male' kaen taro we hem i man

teñtur variety of taro, 'female', with light green stem $\sim$ kaen taro we hem i woman, we han blong hem i laet grin tewesqēqēl variety of taro, 'female' with stem that is white at the bottom and red at top kaen taro we hem i woman, we han blong hem, daon i waet mo antap i red

tewestamal variety of taro, with green stem and black petiole $~$ kaen taro we han blong hem i grin mo i joen long lif hem i blak

tewesvër variety of taro, with red stem and light black petiole $\sim$ kaen taro we kala blong han mo kakae blong hem i miks red wetem waet, skin blong hem i red

titiritōwvetam variety of taro with green stem with brown stripes at base $\sim$ kaen taro we han blong hem i grin wetem braon straep daon

tortor variety of taro, 'female', with stem that is red at the bottom and green at the top kaen taro we hem i woman, we han blong hem i red daon mo grin antap

varvarsō̄m variety of taro with green stem and small black petiole, with white corm kaen taro we han blong hem i laet grin mo kakae i waet

vinmötöl variety of taro, 'female', with black stem and white corm $\sim$ kaen taro we hem i woman, we han blong hem i dak lelebet mo kakae i waet

wakata variety of taro kaen taro

wakata gatgat variety of taro, with white stem and white corm with red stripes kaen taro we han blong hem i waet mo kakae blong hem i waet wetem red straep

wakata mamē variety of taro, 'female', with tall red stem that has white stripes at the bottom, and white corm kaen taro we hem i woman, we han blong hem i longfala mo i red wetem waet straep daon, kakae blong hem i waet 
wakata qagqag variety of taro, 'male', with white stem and corm kaen taro we hem i man, we han mo kakae blong hem i waet

wamal variety of taro that has both 'male' and 'female' varieties, the 'male' with stem that is white at bottom and red at top, the 'female' with purple stem and black petiole kaen taro we $\mathrm{i}$ gat woman mo man wan blong hem, we woman, han blong hem i waet daon mo red antap, mo man, han blong hem $\mathrm{i}$ popel mo i blak long ples we lif i joes waras variety of taro, 'male', with white corm with red points kaen taro we hem i man, we kakae blong hem i waet wetem red long hem

wasalav variety of taro kaen taro

wasanto variety of taro that originated from Santo $\sim$ kaen taro we i kam long Santo

wasanto mamē variety of taro kaen taro

wasanto qagqag variety of taro originating in Santo that has white root $\sim$ kaen taro we i kam long Santo we kakae blong hem i waet

wase $_{2}$ variety of taro that has two types, one with light grey stem, the other with light green stem. They can have lots of forks, but are not good for eating in that case $\sim$ kaen taro we i gat tu kaen blong hem, wan han blong hem i laet grei, wan han blong hem i laet grin. Hem i strong lelebet. Hem i save karem plante fok be sapos olsem kakae i no gud

wederebiliag variety of marē taro that is not large but grows long and crooked, with light red stem with red stripes. The corm is white and is not strong but is good for roasting $\sim$ kaen mare taro we hem i no save bigwan be i save longfala mo i save benben. Han blong hem i laet red wetem ful red laen i go daon. Kakae blong hem i waet mo i no strong. Hem i spesel taro blong rusum

wegeretqon variety of taro $\sim$ kaen taro wēbigqō variety of taro $\sim$ kaen taro wēbigqō mamē variety of taro kaen taro

wēlēbēōr variety of taro, 'female', with light red stem and top with light green stripes $\sim$ kaen woman taro we han blong hem i laet red wetem laet grin straep

wēmēèèglèg variety of taro in marē grouping that has light red stem and white corm. It is stronger than other marē but not that strong kaen marē taro we han blong hem i laet red mo stamba klosap i waet. Kakae blong hem i waet mo hem i strong bitim ol narafala marè be i no strong tumas

wēvē variety of taro that has two types and is like wild taro. The corm is yellow and white inside. It is not strong and can fork kaen taro we $\mathrm{i}$ gat tu kaen blong hem. Hem i olsem waeltaro. Han blong hem i no dak tumas. Taem yu brekem top kakae blong hem i yelo mo i waet insaed. Hem i no strong mo i save karem fok wēvē lamkör variety of wèvē taro that is very white inside but has a dark stem kaen wèvē taro we insaed blong hem $\mathrm{i}$ waet evriwan mo han blong hem i mo dak

wēviti variety of taro kaen taro wotalēbak variety of taro $\sim$ kaen taro wotanaval variety of taro $\sim$ kaen taro wotkērēvōr variety of taro with a greyish stem and white corm. One stem can produce many corms. It is an ideal taro for making löt kaen taro we han blong hem i laet grei mo kakae i waet. Taem yu planem wan nomo be hem i save karem plante kakae. Hem i wan gud taro blong nalot 
wotlalabēvidavaqal variety of taro with dark blue stem and white corm. It does not fork kaen taro we han blong hem i dak blu mo kakae i waet. Hem i no save karem fok

wotliev variety of taro that is one of the largest varieties. There are two kinds, one with a white stem, the other with a darker stem. The corm is white with a light green skin. It can fork kaen taro we hem i bigbigfala taro olgeta. I gat tu kaen blong hem, wan han blong hem i waet, wan han blong hem i dak lelebet. Kakae i waet mo skin blong kakae i laet grin. Samtaem i save karem fok

wotlievgatgat variety of taro kaen taro

wotmēlēv variety of taro $\sim$ kaen taro

wotmindeli variety of taro $\sim$ kaen taro wotminmendala variety of taro kaen taro

wotminsakna variety of taro kaen taro

wotminviolette variety of taro kaen taro

wotminwērirtel variety of taro that has a stem that is red close to the leaf, but white near the corm. It is not large but grows long kaen taro we han blong hem antap, andanit long lif i red be klosap long kakae i waet. Hem i no save bigwan be i save longfala

wotvadadan variety of taro that grows large and has a light green stem and white corm kaen taro we han blong hem i laet grin mo kakae i waet. Hem i save bigbigwan

\section{D4.2 Yam}

bakalav $_{2}$ variety of yam that is between grouping of 'female' and 'male' yams. Unlike most yams, it is not easily recognisable on the basis of its leaf. It is very thorny and is red and white $\sim$ wan kaen yam we hem i no man mo hem i no woman. Hem $\mathrm{i}$ had blong luk save from lif blong hem nomo. I gat tumas nil blong hem mo insaed hem $i$ waet mo red

bargōr $\mathbf{r}_{2}$ yam that is unable to produce large tubers because it is planted with other large crops taem yu planem yam wetem bigfala kakae, yam i no save mekem bigfala kakae

dem (fr.var. dëm) yam yam Dioscorea spp.

dem atat̄̄ēn primary grouping of varieties of yam, yams that bear long tubers ol kaen yam we kakae blong olgeta ol i longlongfala

dem bōnōbōn variety of yam belonging to 'male' grouping, that has a distinctive smell wan kaen yam we i longfala mo i waet mo i gat smel blong hem

dem getō variety of yam that has red tuber, with varieties belonging to both 'male' and 'female' groupings $\sim$ wan kaen yam we insaed i red evriwan, i gat woman kaen mo man kaen tu

dem kēèeglēg primary grouping of varieties of yam, yams that bear crooked tubers ol kaen yam we kakae blong olgeta ol i kruked

dem rereqe primary grouping of varieties of yam, yams that bear short tubers ol kaen yam we kakae blong olgeta ol i sotsotfala

dem ga variety of yam that is not planted but grows wild in the bush kaen wael yam blong bus

dōr variety of wild yam strong wael yam

mēlin variety of yam that is grouped with the 'male' yams and is white inside wan kaen yam we $i$ longlongfala mo insaed i waet

mat variety of yam that belongs to the grouping of 'crooked' yams kaen yam we i stap long grup blong ol kruked yam 
qōlmo variety of yam that belongs to the grouping of 'crooked' yams kaen yam we i stap long grup blong ol kruked yam

qōōr wild yam wael yam Dioscorea nummularia

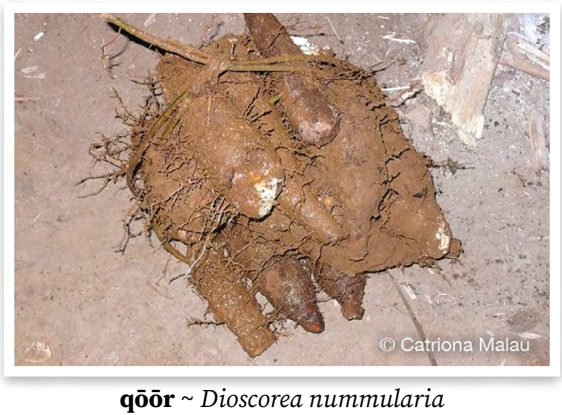

$\operatorname{taw}_{2}$ variety of yam that belongs to the grouping of 'female yams', which is white and soft wan kaen yam we $i$ sofsof mo i waet. Hem i save gro raon be samtaem i flat

walalas kind of wild yam wan kaen yam we hem i gru wael Dioscorea pentaphylla

walalnelan kind of yam that has a round shape, is white and can grow large wan kaen yam we hem i raon gud mo hem $i$ save bigbigwan mo hem i waet insaed

weag wild yam wael yam Dioscorea nummularia

wēbiēg variety of yam with a double layer of skin wan kaen yam we i gat dabol skin

wēbiēg atatīēèn variety of yam with a double layer of skin and white flesh wan kaen man yam we i gat dabol skin mo insaed i waet

wēbiēg rereqe variety of yam that can be red or white wan kaen woman yam we insaed i red o waet

wēkēr wōnwōn variety of yam belonging to the 'female' grouping $\sim$ wan kaen yam we i no save gro longfala tumas be i save gro bigfala. insaed blong hem i waet wēlir variety of yam that is not planted but grows wild in the bush $\sim$ wan kaen wael yam we i save longlongfala (olsem man) be i smol nomo antap we i mekem se $\mathrm{i}$ had blong digim

wōqōlmō kind of yam that is shaped like a crescent moon and can come out of the ground as it grows. There are two kinds, one with red skin, the other with white skin wan kaen yam we hem i sep olsem niu mun mo hem i gro i save kam antap long graon bakegen. I gat tu kaen blong hem, wan skin blong hem i red, wan i waet

wöböw (abbrev. ga wöböw) aerial yam nabew, konkon yam Dioscorea bulbifera

wötörövarvar variety of yam which belongs to the grouping of 'male' yams wan kaen yam we i longlongfala mo insaed long hem i stat antap hem i red, i go daon long medel i miks red mo waet mo long en blong hem i waet

wöuw kind of yam that is very productive. It is one of the best tasting yams and is often grown in the taro garden $\sim$ wan kaen yam we hem i karem fulap kakae. Plante taem ol i planem long garen taro. Tes blong hem i gud, klosap i bitim ol narafala yam

\section{D4.3 Cassava}

atina cassava variety $\sim$ kaen maniok

maniok cassava, manioc maniok Manihot esculenta

maniok añan variety of cassava that has yellow tubers kaen maniok we kakae blong hem i yelo

maniok atatīēn primary grouping of varieties of cassava, cassava that bear long, large tubers ol kaen maniok we kakae blong olgeta ol i longlongfala mo i bigwan 
maniok rereqe primary grouping of varieties of cassava, cassava that bear round, short tubers ol kaen maniok we kakae blong olgeta ol i raon mo i sotfala

raēs ga qag cassava variety $\sim$ kaen maniok

raēs mamē cassava variety kaen maniok

saemon cassava variety kaen maniok sus atat̄̄ēn variety of cassava belonging to 'male' grouping, with long, large tubers kaen maniok we kakae blong hem i longfala mo i bigwan

sus rereqe variety of cassava that has round, short tubers kaen maniok we kakae blong hem i raon mo i sotfala

vasēr cassava variety kaen maniok

\section{D4.4 Sweet potato}

ga dōvōr ${ }_{2}$ variety of sweet potato which is named for plant of same name as it has large leaves like that vine $~$ kaen kumala we i gat bigfala lif

pawa variety of sweet potato that has green vine $\sim$ kaen kumala we rop blong hem i grin

spidbōt variety of sweet potato that is named for the fact that it grows very quickly kaen kumala we ol i putum nem blong hem from hem i gro kwiktaem tumas

tövutwen variety of sweet potato that has a greenish vine $~$ kaen kumala we rop blong hem i grin smol

tri manis variety of sweet potato that is valued as it bears tubers only three months after planting kaen kumala we i stap tri manis nomo, afta i karem kakae

$\operatorname{vorog} 1 \cdot$ sweet potato variety $\sim$ kaen kumala

wese to $\overline{\mathbf{o}}_{2}$ variety of sweet potato that is so named as it is shaped like a chicken's egg kaen kumala we i tekem nem blong hem from i sep olsem eg blong faol
D5 Miscellaneous plants

dagarē (root garē) victory leaf, ti plant $\sim$ nanggaria Cordyline terminalis, $C$. fruticosa

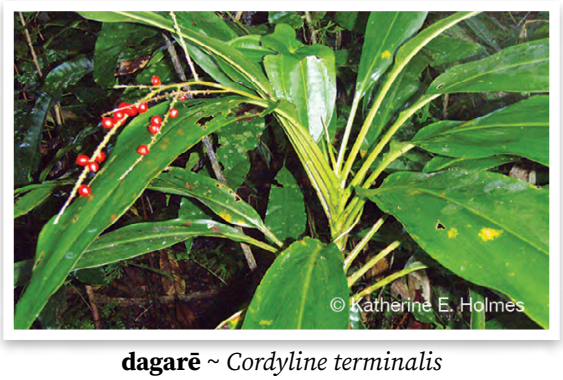

damatmot canna lily wan kaen flaoa Canna indica

damalak crinum lily, spider lily kaen waet flaoa Crinum asiaticum

damataq kind of small flowering plant with tiny mauve flowers wan kaen plant we i gat smolsmol popel flaoa Veronia cinnerea

dasas fern (generic) fens

dasas qötu riaw kind of fern wan kaen fens Angiospermum evecta

dasas tie tō kind of fern wan kaen fens Spherostephanos invisus

dēnin (fr.var. dinin) leaf like heliconia but smaller lif olsem lif laplap be i smolsmol Cominsia gigantea

dēqēt bird's nest fern wan kaen lif we i stap gro long stamba blong wud Asplenium nidus

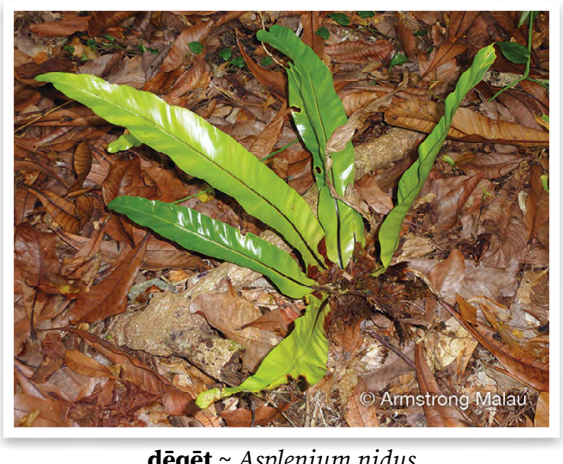

dēqēt Asplenium nidus 
dobormiak plant with strong scented yellowish, green leaves lif we $i$ gat smel blong hem we i yelo, grin Kopsia flavida

dōmōtōtak plant related to kava but which cannot be made into kava waelkava Macropiper latifolium

dōmōtōtak mamē plant related to kava with dark red leaves and branches waelkava we lif mo han blong hem i red

dökurut kind of wild pandanus, with yellow flower, fruit is red when ripe olsem wan kaen wael pandanas we i gat nil long lif blong hem Freycinetia tannaensis

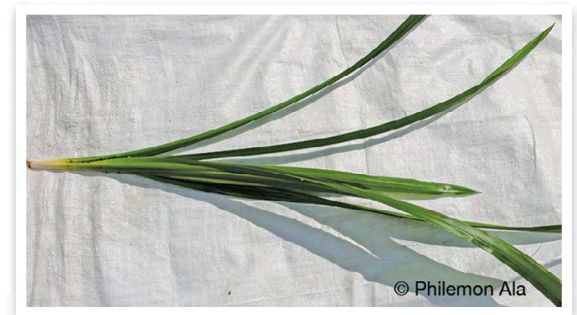

dökurut $\sim$ Freycinetia tannaensis

dötöqötun plant with stinging nettle like leaves with a serrated edge and tiny flowers wan kaen plant we hem i save kakae skin blong yu

gatavdor type of ginger plant kaen flaoa Alpinia sp.

gē $\mathbf{1}$ - kava plant kava Piper methysticum

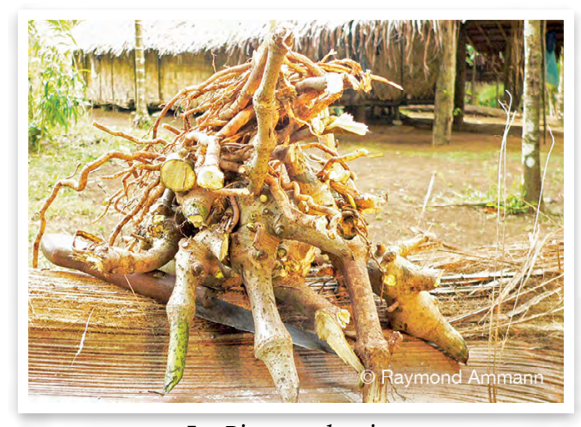

$\mathbf{g e ̄} \sim$ Piper methysticum lēnötō ${ }_{2}$ red firespike, kind of flowering plant with red flowers that look like rooster's comb wan kaen plant we i gat red flaoa blong hem we i luk olsem samting antap long hed blong man faol Odontonema stricta

lösönqō plant belonging to ginger family plant we hem i famle blong jinja Alpinia pacifica

lumlum 1 • seaweed nalumlum (blong solwota) $\mathbf{2} \cdot$ moss, algae nalumlum (long wud, long bus)

low kind of edible seaweed, which has two types, one red, one yellow $\sim$ kaen nalumlum blong solwota we yu save kakae

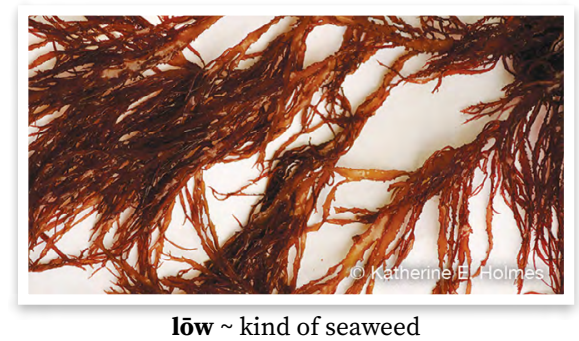

mèl cycad namele Cycas seemannii mēel añan̄ kind of cycad kaen namele

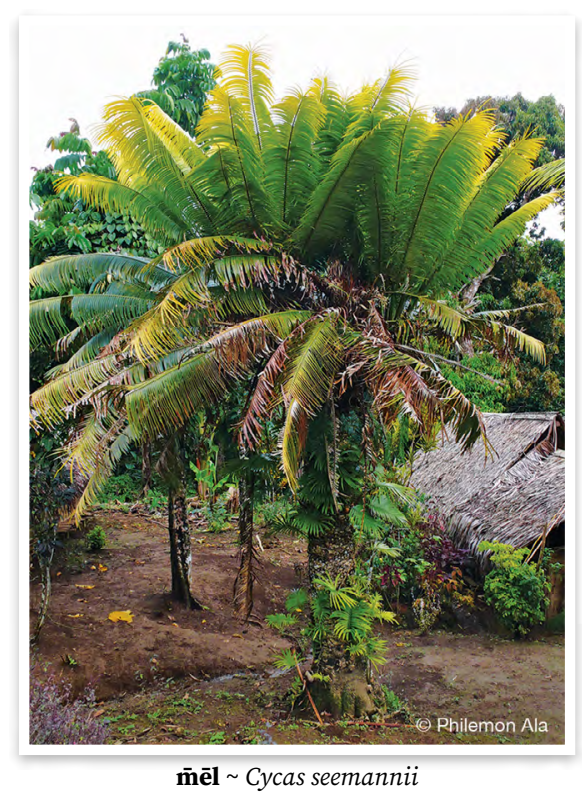


mēvinvian (fr.var. M̄ivian; mivinvian) kind of plant wan kaen plant Coprosma persicaefolia

nisnias kind of plant $\sim$ kaen plant Elatostagis falcata

pomken pumpkin pamken

$\mathbf{q} \overline{\mathbf{o}}_{3}$ kind of plant with thick succulent leaves, white flowers and red fruit with black seeds kaen plant we i gat waet flaoa, red frut mo blak sid Tapeinochilus sp.

raminwōlōnmögörviaomōtōsur bok choy, Chinese greens waetbun, jaenis kabis

tartarawöw kind of plant kaen plant Leea indica

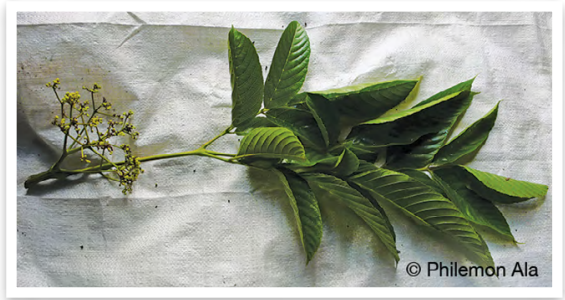

tartarawöw Leea indica

van $_{3}$ pineapple $\sim$ paenapol Ananas comosus

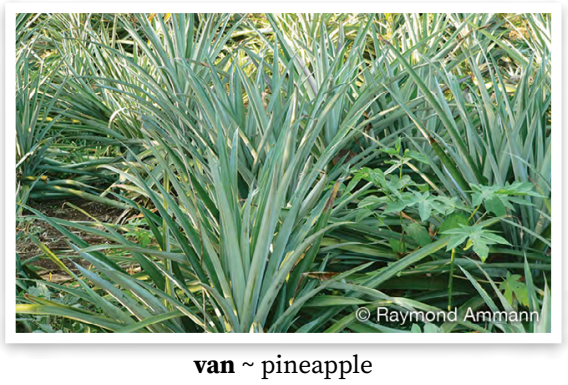

visō pitpit, duruka, vegetable cane naviso Saccharum edule

wamamēgin type of croton with green leaves famle blong kala lif be lif blong hem i grin nomo Codiaeum variegatum wamā̄as kind of plant wan kaen plant Evodia latifolia

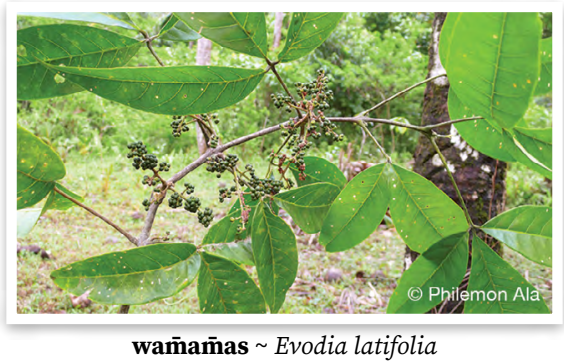

wedeldel red ginger, kind of flowering plant red flaoa we hem i famle blong jinja Alpinia purpurata

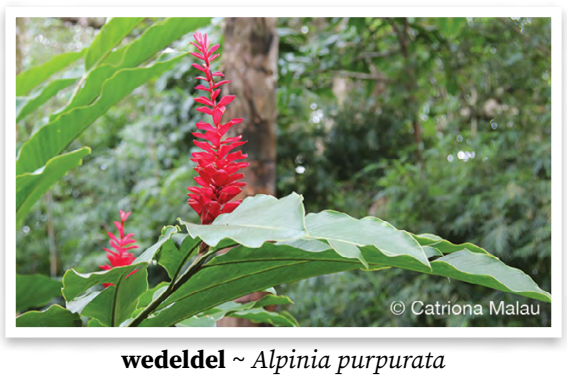

wesev plant with strong scented yellowish, green leaves lif we $\mathrm{i}$ gat smel blong hem we i yelo, grin Evodia hortensis

widiar 1 - kind of mushroom that glows in the dark kaen masrum we i stap saen long naet

wistaban variety of kava with yellow leaves wan kaen kava we lif blong hem i yelo

wolkoko kind of plant that has small sharp hooks on the stem $\sim$ wan kaen plant we i gat huk long hem Caesalpinia crista

wulëwalal devil's horsewhip kaen plant Achyranthes aspera 


\section{E Fauna}

\section{E0 General}

bakasē abdomen, under side of crabs and other crustaceans andanit, bel blong krab o naora

bēni $\mathbf{1} \cdot$ hand, arm han $\mathbf{2}$ - wing of bird wing blong pijin

banēn gala her/his/its left hand lef han blong hem

banēn mōtō her/his/its right hand raet han blong hem

banēn her/his/its hand han blong hem

bēnik my hand han blong mi

busu 1 - digit, finger, toe $\sim$ fingga 2 • claw fingga blong pijin, fingga blong krab, naora

bōsōn her/his/its finger, toe fingga blong hem

busu ōr prawn or lobster claw fingga blong naora

busuk my finger, toe fingga blong mi

dir ${ }_{1}$ hatch (eg i) brok

dōsdōs $1 \cdot \operatorname{coo}$, make noise like dove (grinpijin o sotleg) i singaot, mekem noes blong hem

gaböu wing wing

gabōōn its wing wing blong hem

gaböuk my wing wing blong mi

gargarke type of fatty looking substance, part of animal samting olsem gris we i stap wetem mit blong animol

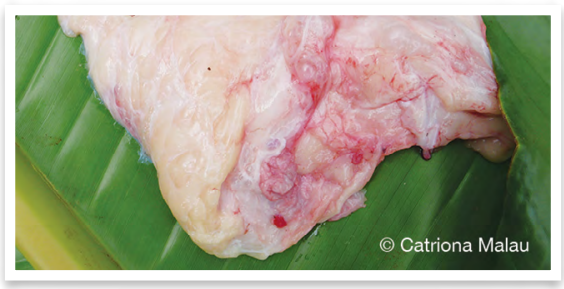

gargarke $\sim$ fatty substance

golon her/his/its tail tel blong hem gölö tail tel gölök my tail tel blong mi

lēnötō ${ }_{1}$ rooster's comb red samting we i stap antap long hed blong man faol

luwö $\mathbf{1} \cdot$ tooth $\sim$ tut $\mathbf{2} \cdot$ tusk $\sim$ tut (blong pig)

luwö bas toothless person, person who has lost all or most of their teeth $\sim$ man we i nogat tut

luwö qō pig's tusk tut blong pig

luwon her/his/its tooth, teeth tut blong hem

luwök my tooth, teeth tut blong mi marak fat (of animal) gris (blong animol)

men $_{1}$ bird $~$ pijin

mes fish $\sim$ fis

mō long feather of a rooster's tail longfala feta long tel blong man faol m̄ēmēri tentacle, arm of octopus han blong nawita

nere $\mathbf{1} \cdot$ lips $\sim$ lip, skin blong maot $2 \cdot$ beak $\sim$ maot blong pijin

naran her/his/its lips, beak skin blong maot blong hem

nërëk my lips skin blong maot blong mi

nusu $1 \cdot$ lips, snout (of animal such as pig) lip, skin blong maot $\mathbf{2} \cdot$ beak maot blong pijin

n̄ōsōn her/his/its lips, beak skin blong maot blong hem

nusuk my lips skin blong maot blong mi

seleqō animal animal

sōrsōr noise made by cicada noes we bebet we i kolem se bōn i mekem

taqtutun $1 \cdot$ sit on egg (of bird) pijin i slip long eg kasem taem eg i brok

tatörur noise made by pigeon $~$ noes blong nawimba

tikiar sound made by hen after laying an egg saon olsem woman faol i singaot afta hem i putum eg 


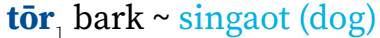

törtörök crow, sound made by rooster

$\sim$ man faol i singaot

tötöu nest nes

tötöu men bird's nest nes blong pijin

tutgö fin wing blong fis

vul $\mathbf{1}$ • hair $\sim$ hea $\mathbf{2}$ - feather $\sim$ feta

vōlōn her/his/its hair hea blong hem

vulu tō chicken feather $\sim$ feta blong faol

vuluk my hair hea blong mi

wawawne gill sora blong fis

wawleñ wing tip en blong wing

wēlēgian $\mathbf{1} \cdot$ her/his/its heel $\sim$ bihaen blong leg blong hem 2 - hoof (of animal) bihaen long leg blong animol

wobalaklak sucker, suction cup on octopus arm, tentacle samting long han blong nawita we yu save fas long hem

wotoqtoqolav stomach of cattle (cows only) bel blong buluk

wörurus tavav pancreas wan pat blong animol we i stap wetem gat

wöwöwut smaller stomach of cattle, omasum handred rum (blong buluk)

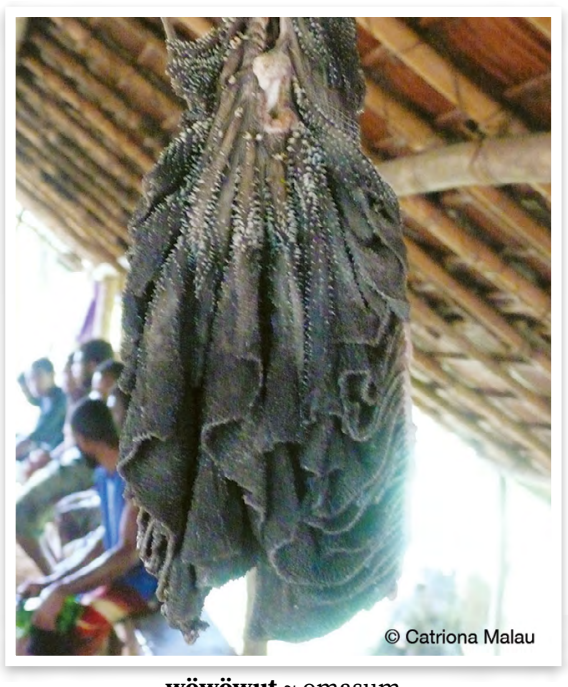

wöwöwut omasum wulewēsēstoñov operculum ae

blong grinsnel

E1 Mammals

buluk cow, cattle buluk

genqirēg $\operatorname{dog} \sim \operatorname{dog}$

gōsōw rat rat

mal sow pig woman

qërët flying fox $\sim$ flaengfokis

$\mathbf{q} \overline{\mathbf{o}}_{1}$ pig pig

riaw $\mathbf{1} \cdot$ hermaphrodite $\sim$ animol we hem i man mo woman wantaem 2 - intersex pig pig we hem i man mo woman wan taem

tëqël bat bat

tivi cat puskat

tok dog $\sim \operatorname{dog}$

E2 Birds

bagbaglō swiftlet wan kaen pijin Aerodramus spp.

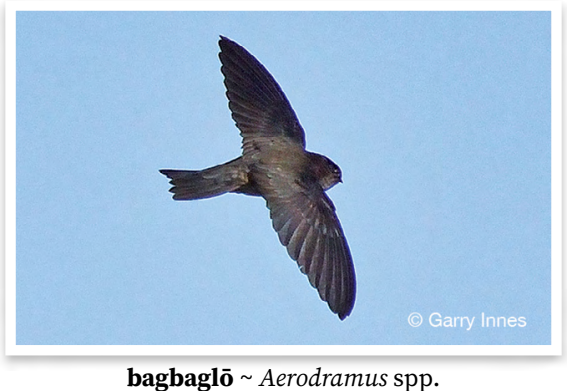

bëlbëlvōlōn small Vanuatu fruit dove $\sim$ grinpijin

biliag buff-banded rail nambilak Gallirallus philippensis

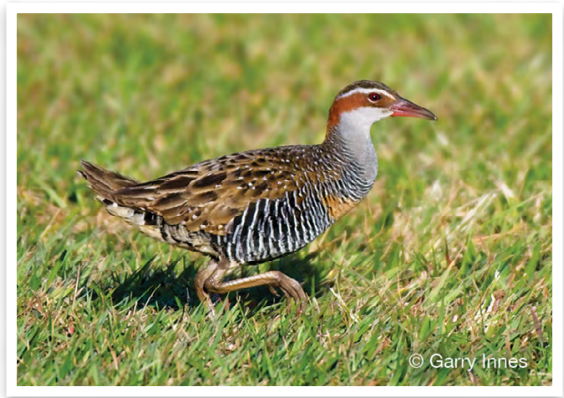

biliag Gallirallus philippensis 
biliag mamē white-browed crake wan kaen pijin Poliolimnas cinereus gōg reef heron longnek; naova Ardea sacra, Egretta sacra

gōg gabēt white heron waet longnek

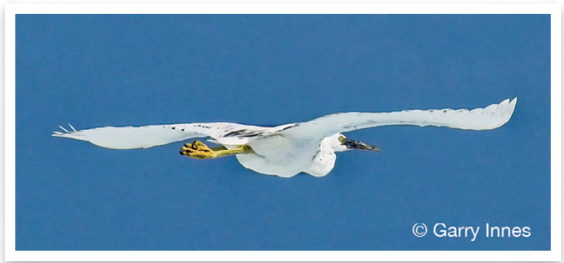

gōg gabēt white heron

gōg kör black heron blak longnek

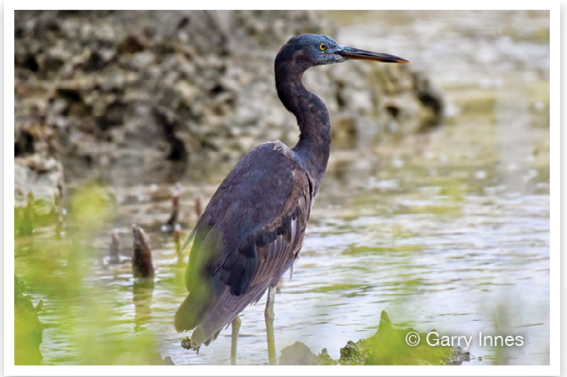

gōg kör black heron

mal common hawk, swamp harrier namala, igel, hok Circus approximans

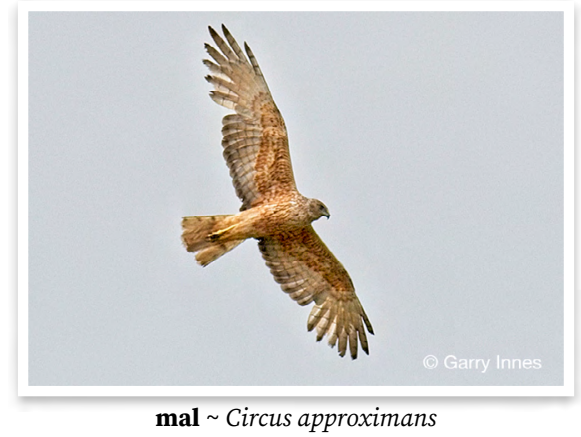

mal biliag peregrine falcon kaen pijin olsem hok be wing blong hem i longwan, bodi blong hem i moa smol Falco peregrinus

male $\overline{\mathbf{e}}_{1}$ bird species kaen pijin

malqon fruit dove $\sim$ grinpijin Ptilinopus spp. men $_{1}$ bird pijin

men dōsdōs fruit dove $\sim$ grinpijin

Ptilinopus spp.

menmenlul golden whistler $\sim$ wan kaen pijin

mensirsirqōōr Vanuatu buff-bellied flycatcher $\sim$ wan kaen pijin Neolalage banksiana

mēs rainbow lorikeet nasiviru Trichoglossus haematodus

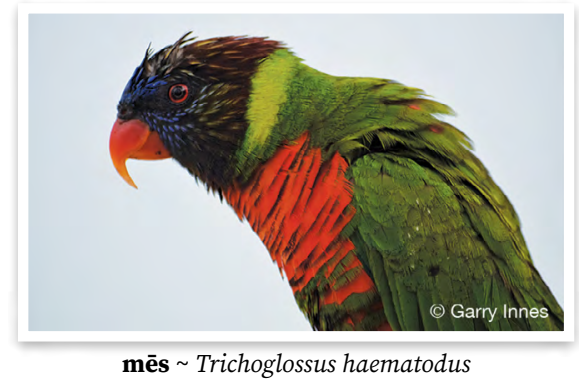

mëkbē broad-billed flycatcher wan kaen pijin Myiagra caledonica

matēk purple swamphen napiru, longnek Porphyrio porphyrio

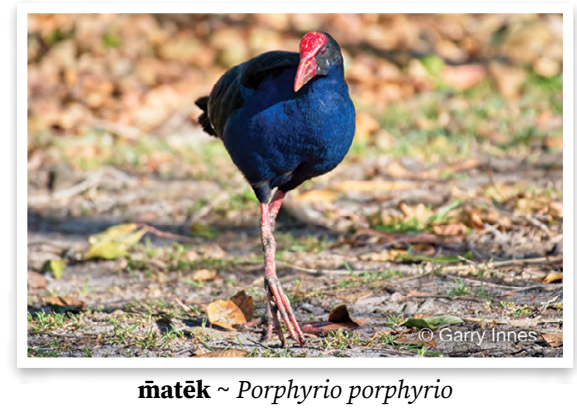

mereg 1 Pacific emerald dove $\sim$ sotleg Chalcophaps longirostris

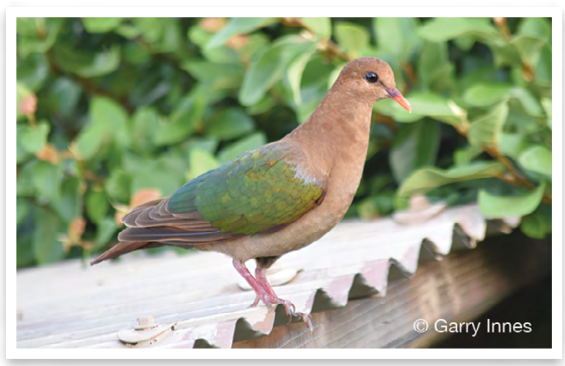

mereg Chalcophaps longirostris 
mēēlēg Vanuatu white-eye nalaklak wetem yelo bel Zosterops flavifrons mēēēg wö silvereye nalaklak Zosterops lateralis

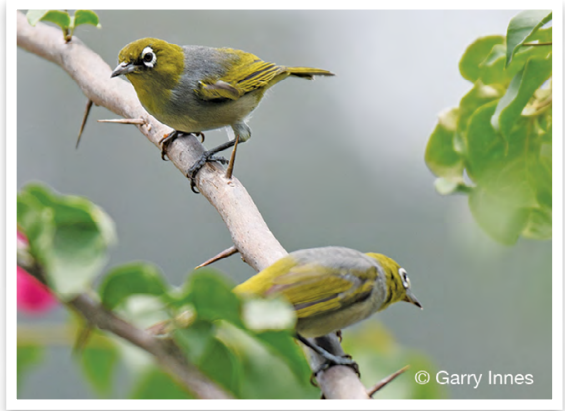

$\overline{\mathbf{m}} \mathbf{e} \mathbf{l e ̄ g}$ wö $~$ Zosterops lateralis

molo incubator bird, scrub fowl, megapode skrabdak, namalao Megapodius freycinet

qërët flying fox flaengfokis qon pigeon nawimba Ducula spp.

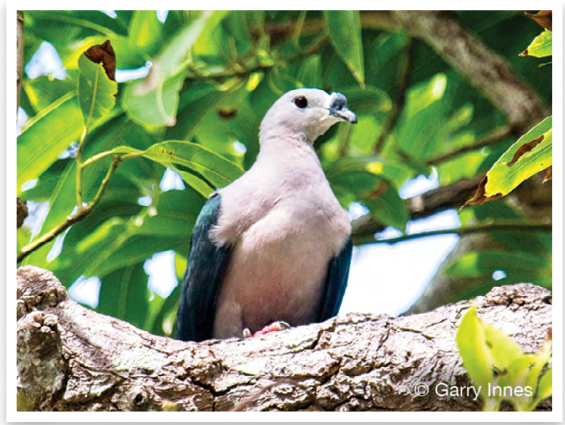

qon Ducula spp.

qon bulënqet kind of pigeon that has a ring on its leg kaen nawimba we i gat ring long leg blong hem

qon bulënrēlē kind of pigeon that has a lump on its beak (male) kaen nawimba wetem lam long maot blong hem (man)

qon tan̄sar kind of pigeon that has a straight beak (female) kaen nawimba we $i$ gat stret maot (woman)

qon wēbèt kind of pigeon that is white $\sim$ waet nawimba qötqötumen cardinal honeyeater (male) redhed (man) Myzomela cardinalis

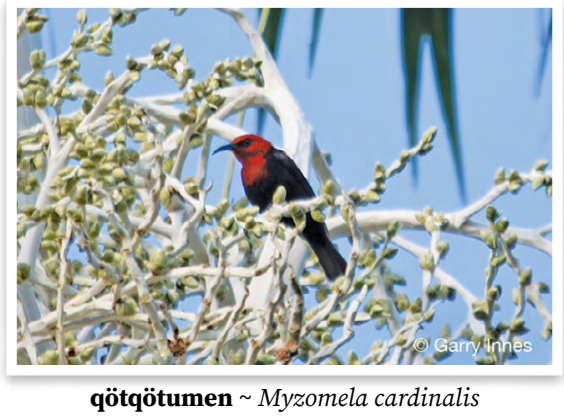

rēn̄ēs green palm lorikeet wan kaen pijin olsem nasiviru Charmosyna palmarum

sēg kingfisher nasiko, longmaot Todiramphus spp.

sēg malgias Pacific kingfisher nasiko Todiramphus sacer

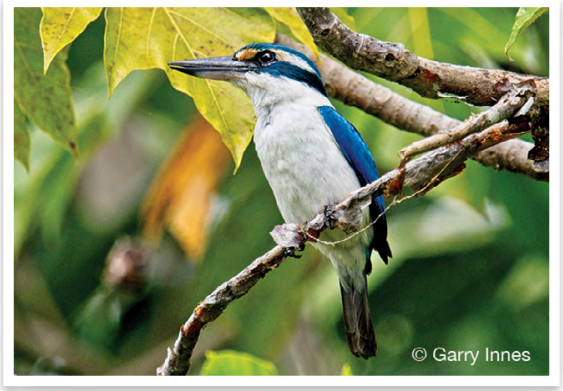

sēg malgias Todiramphus sacer

sēg mamē sacred kingfisher red nasiko Todiramphus sanctus

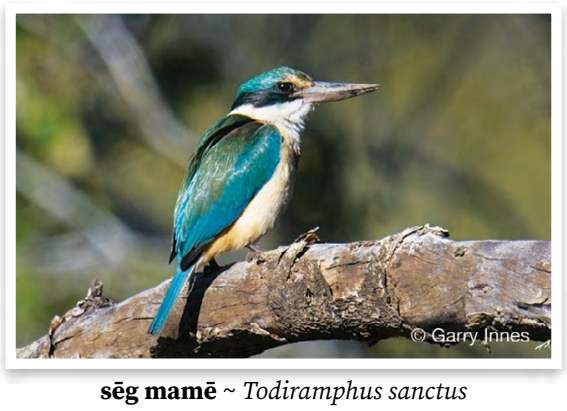

sōravar Vanuatu fruit dove bigfala grinpijin Ptilinopus tannensis 
tarere young chicken that is not a chick but not yet fully mature yang faol

taw $_{1}$ dark-brown honeyeater, greyeared honeyeater kaen pijin wetem longmaot, famle blong redhed we hem i braon Lichmera incana

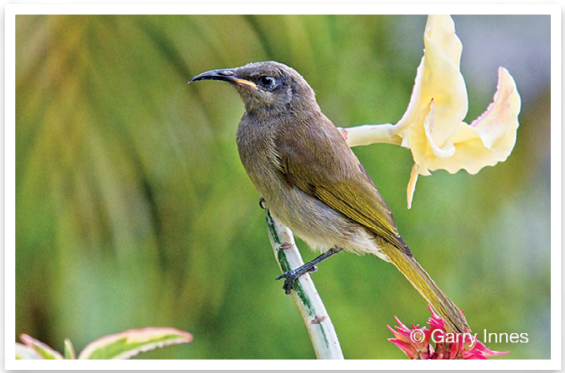

taw Lichmera incana

tēgēr fantail pijin blong trik Rhipidura spp.

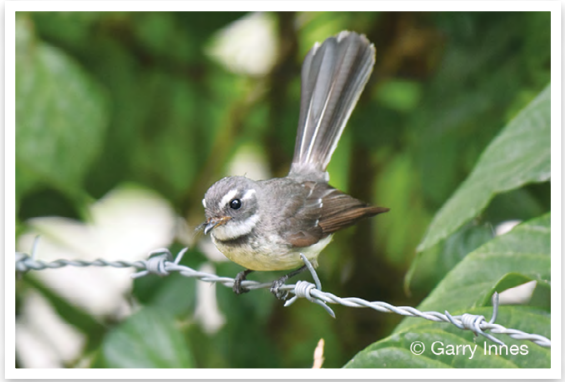

tēgēr Rhipidura spp.

tēwē shore birds pijin blong solwota tēwē biliag wandering tattler nasivi Heteroscelus incanus

tēwē ōlqön kind of shore bird smolsmol nasivi we hem i stap singaot oltaem

tēwē rōwelteg beach thick-knee kaen nasivi Esacus magnirostris

tërëw Vanuatu mountain pigeon nawimba blong hil Ducula bakeri

tōo ${ }_{1}$ chicken faol Gallus gallus nötu tō chick pikinini blong faol tō armiag chicken with light reddish brown feathers $\sim$ faol we kala blong hem i laet braon

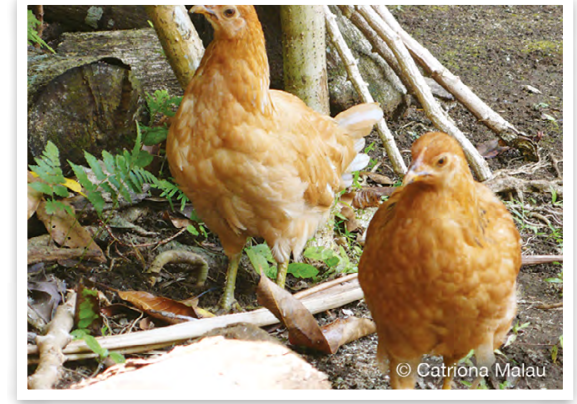

tō armiag brown chicken

tō atm̄ēn rooster $\sim$ man faol

tō bèt white chicken $\sim$ waet faol

tō biliag speckled chicken with colouring like buff-banded rail $\sim$ faol we kala blong hem i olsem nambilak

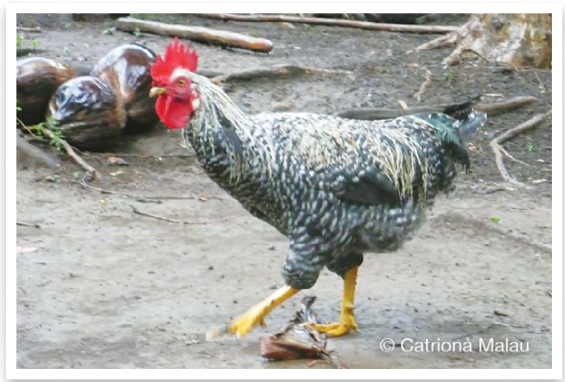

tō biliag speckled chicken

tō kör black chicken blak faol tō mamē red chicken $\sim$ red faol

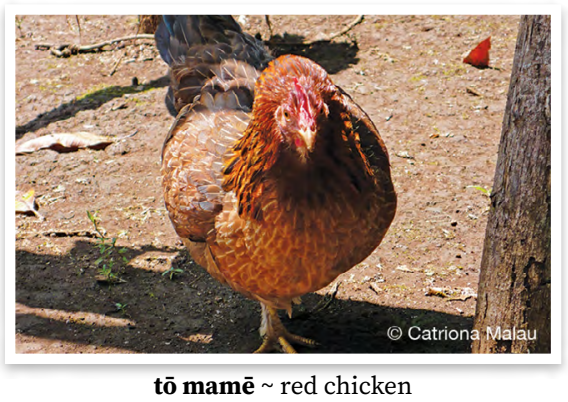

tō menmenlul red, white and black chicken faol we i gat tri kala long hem, red, waet mo blak

tō reqe hen $\sim$ woman faol 
tōrō white-throated pigeon nataroa Columba vitiensis

tōrō butbut male white-throated pigeon $\sim$ man nataroa

tōwav ${ }_{2}$ rufous-brown pheasant-dove longtel Macropygia mackinlayi

tutrevak kind of bird like a Vanuatu mountain pigeon but bigger wan kaen pijin olsem nawimba blong hil be bigwan

tutwō kind of bird like a Vanuatu mountain pigeon but smaller wan kaen pijin olsem nawimba blong hil be i smol lelebet

wase $_{1}$ southern shrikebill kaen pijin we hem i braon mo blak Clytorhynchus pachycephaloides

wètēbisbis island thrush wan kaen pijin Turdus poliocephalus

wētēsisis cardinal honeyeater (female - smaller and not as brightly coloured as male) redhed (woman) Myzomela cardinalis

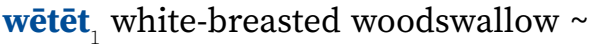
wan kaen pijin Artamusleucorhynchus

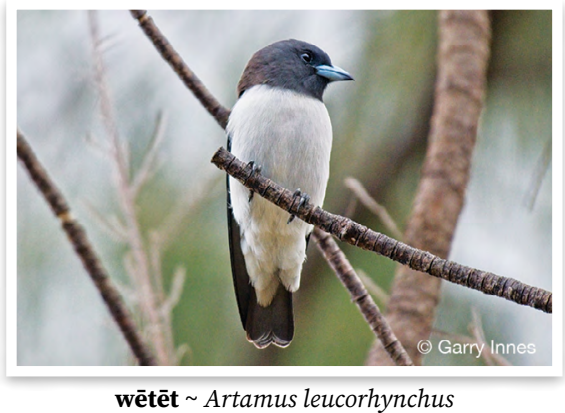

wēvēl fantail warbler wan kaen pijin Gerygone flavolateralis

wiria red-bellied fruit dove (immature(?), smaller and colour not as bright) grinpijin we hem $\mathrm{i}$ smol Ptilinopus greyii

wiria tabē red-bellied fruit dove (adult(?), larger) grinpijin we hem i bigwan Ptilinopus greyii

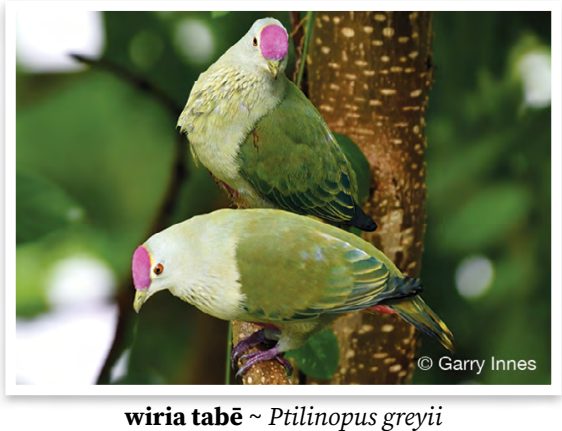

wis barn owl hoknaet, wok naet Tyto alba

wotoqtoq mamē scarlet robin wan kaen pijin Petroica multicolor wōkōl Vanuatu mountain honeyeater longmaot blong hil Phylidonyris notabilis

wōrdes Polynesian triller wan kaen pijin Lalage maculosa

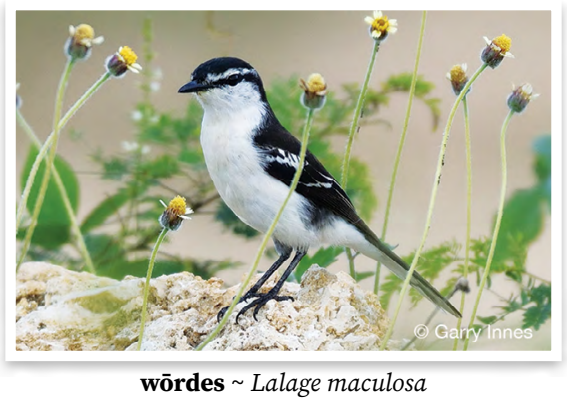

wōtōkōl whimbrel wan kaen pijin Numenius phaeopus

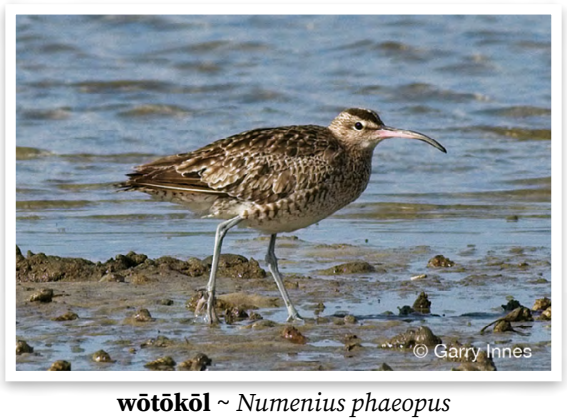




\section{E3 Reptiles}

kakēlis brown striped lizard braon lised wetem laen

kalmōs kind of lizard that is black with green-yellow belly wan kaen lised we hem i grin mo blak

kalqar green tree lizard $\sim$ grinlised Emoia sanfordii

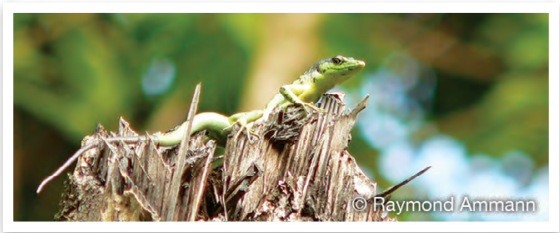

kalqar Emoia sanfordii

matawōsōl kind of lizard that is light brown with spots on its back and yellow belly. It sheds its skin when touched $\sim$ wan kaen lised we hem i laet braon wetem spot long baksaed mo yelo andanit. Taem yu holem skin blong hem i kamaot

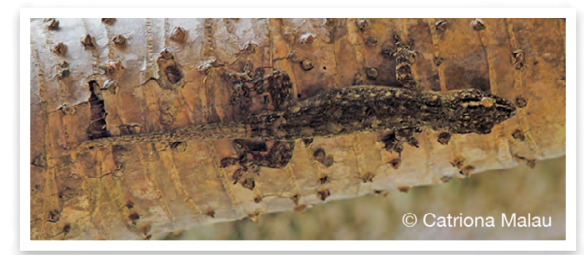

matawōsōl kind of lizard

matriaw lizard $\sim$ lised

mōs black lizard blak lised

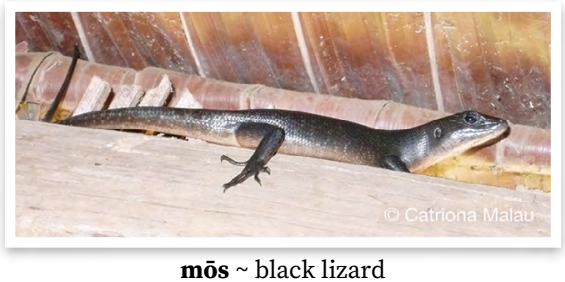

mat snake $~_{\text {snek }}$

mat an kind of snake that is yellow kaen snek we i yelo

mat biliag kind of snake that is spotted kaen snek we $\mathrm{i}$ gat dot long hem mat tan tes sea snake that is short and yellow and is found on surface wan snek blong solwota we i yelo mo i sotfala mo i stap swim antap long ol wef

tanlēn̄lēn kind of small black lizard that is found underneath logs and rocks wan kaen smol blak lised we hem i stap andanit long wud o ston

tilē tan kind of snake kaen snek

viabobo kind of dark brown lizard with large eyes. Its skin is rough and can scratch one's skin wan kaen lised we hem i dak braon mo hem i bigwan wetem bigbig ae. Skin blong hem i raf mo strong mo hem i save skrasem skin blong yu

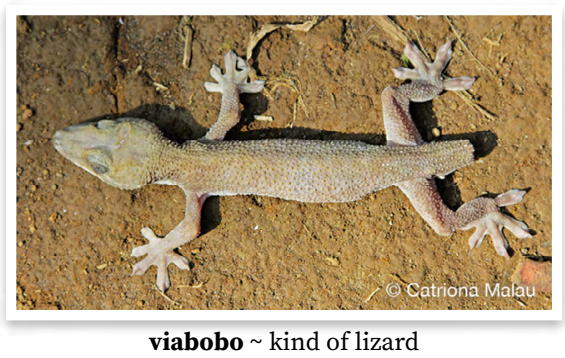

E4 Water creatures

\section{E4.0 Large sea creatures}

bōgō ${ }_{1}$ shark sak

bōgō dēmēèl blue shark wan kaen sak

bōgō mes sandbar shark wan kaen sak

bōgō n̄ōrn̄ōr leopard shark wan kaen sak

göwur white-margined moray wan

kaen namarae

$\mathbf{k} \overline{\mathbf{e}}_{1}$ dolphin dolfin

$\overline{\mathbf{o w}}$ turtle $\sim$ totel

qōlo dugong kaofis Dugong dugon

rērēg whale $\sim$ welfis

val hookjaw moray kaen namarae

vër ${ }_{1}$ stingray stingre 
vër dudut black-blotched stingray $\sim$ wan kaen stingre Taeniura melanospila

vër mal spotted eagle ray wan kaen stingre Aetobatus narinari vër matawasē Kuhl's stingray wan kaen stingre Neotrygon kuhlii

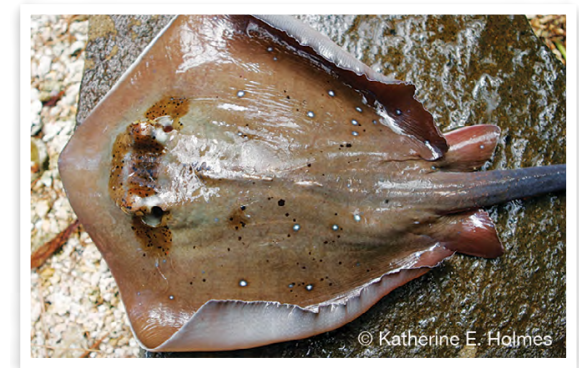

vër matawasē $~$ Neotrygon kuhlii

vër timiat manta ray wan kaen stingre Manta birostris

\section{E4.1 Fish}

bargōr 1 kind of flying fish that is found close to shore wan kaen smol flaengfis we i stap klosap long SO

barnaw doublespotted queenfish kaen fis Scomberoides lysan

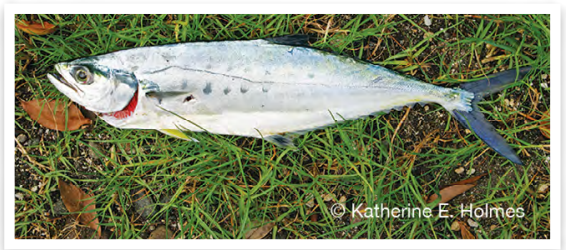

barnaw Scomberoides lysan

batbat red-tailed leatherjacket $\sim$ kaen strongskin

baw onespot snapper kaen pulefis we i gat yelo tel mo wan blak spot long hem Lutjanus monostigma

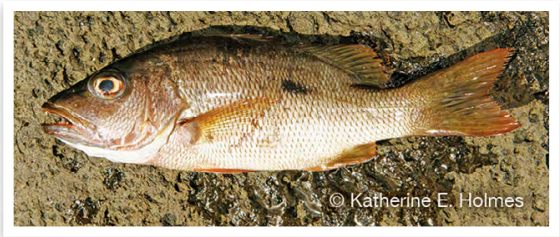

baw Lutjanus monostigma benmē kind of large flying fish with reddish pectoral fins $\sim$ wan kaen flaengfis we hem i bigwan mo wing blong hem i haf red

benmō̄olo black sweetlips tiklips Plectorhinchus gibbosus

beraw striped surgeonfish $\sim$ renbofis, blumak piko Acanthurus lineatus

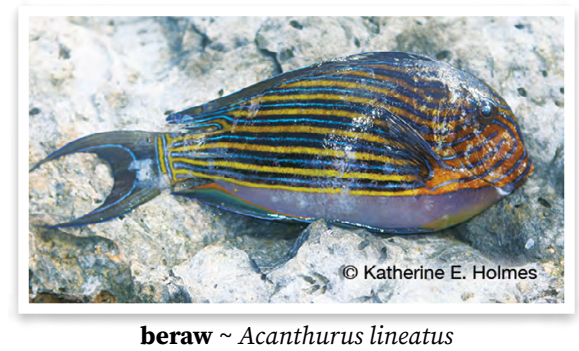

beretnaw common dart $\sim$ kaen fis Trachinotus botla

bēm butterflyfish bataflae fis Family Chaetodontidae

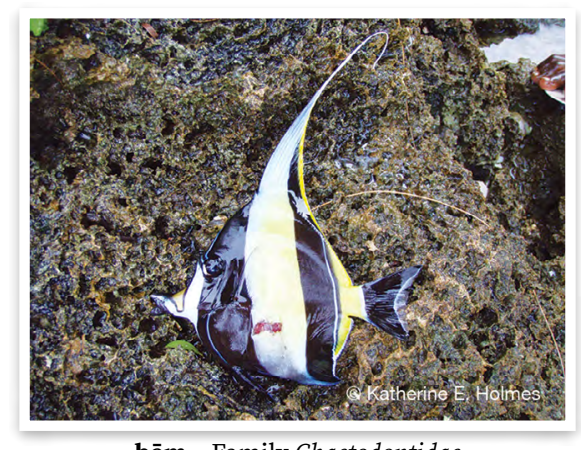

bēm Family Chaetodontidae

biliag $_{2}$ darkfin hind $\sim$ kaen los Cephalopholis urodeta

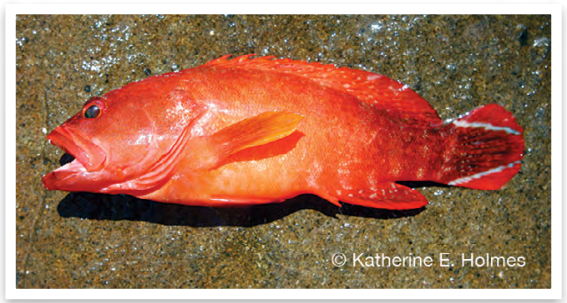

biliag Cephalopholis urodeta

biliag lam leopard grouper kaen los Cephalopholis leopardus borbor $_{2}$ kind of fish $\sim$ kaen fis 
bultarō yellowmask angelfish, regal angelfish papiong fis Pomacanthus xanthometopon, Pygoplites diacanthus bum triggerfish strongskin Family Balistidae

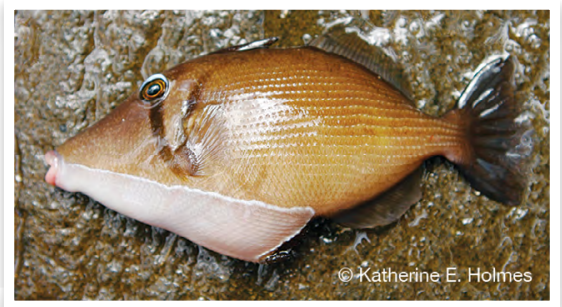

bum $\sim$ Family Balistidae

bum gōlōw black triggerfish kaen strongskin

bum lam starry triggerfish kaen strongskin Abalistes stellaris

bum lo kind of triggerfish kaen strongskin

bum qërët redtooth triggerfish kaen strongskin Odonus niger

bum timiat orangelined triggerfish kaen strongskin Balistapus undulatus

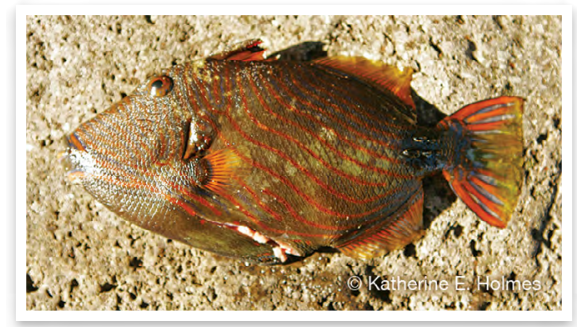

bum timiat $\sim$ Balistapus undulatus

dananar Indo-Pacific sergeant, scissortail sergeant $\sim$ wan kaen fis Abudefduf vaigiensis, Abudefduf sexfasciatus

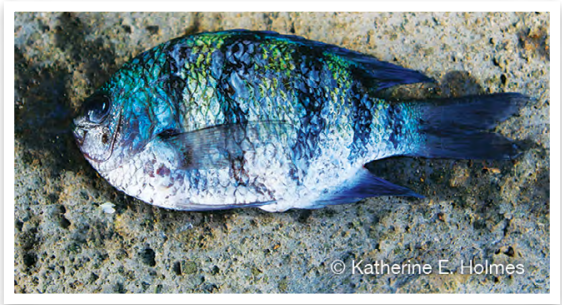

dananar Abudefduf spp. datalēs flametail snapper kaen pulefis Lutjanus fulvus

demeles general name for immature parrotfish species ol smol blufis we ol i no kam bigwan yet Chlorurus sordidus

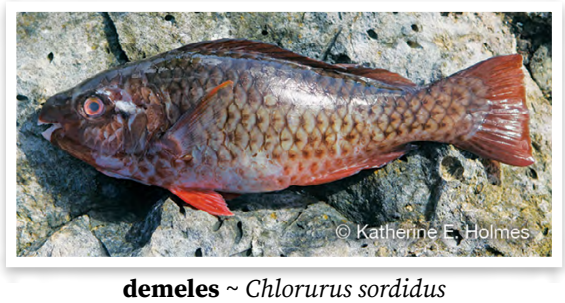

dēvēlavēl steephead parrotfish kaen

blufis Chlorus microrhinus

dëvër orbicular batfish wan kaen fis

Platax orbicularis

dōmōtō blackspot emperor blakspot redmaot Lethrinus harak

dötöv bluefin trevally blu karong Caranx melampygus

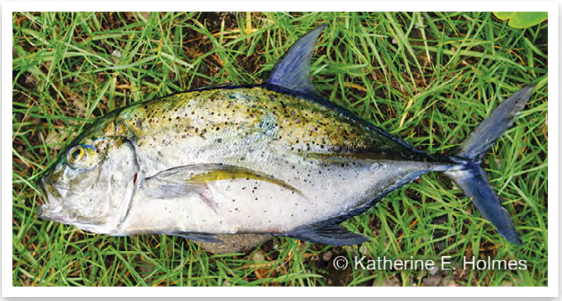

dötöv Caranx melampygus

ët tuna tuna

ganasēg freckled porcupinefish, black-blotched porcupinefish nilfis Diodon spp.

gie whitespotted surgeonfish $\sim$ wan kaen fis Acanthurus guttatus

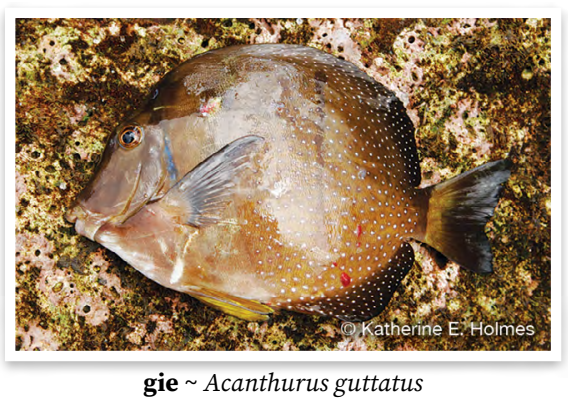


giebe kind of freshwater fish that is black with white stripes. It is flat, can be large, and is always found in pairs wan kaen fis blong wota we hem i blak wetem dak waet laen. Hem i flat mo hem i save bigwan. Ol taem ol i stap tu tugeta

ginias sixfinger threadfin $~$ wan kaen fis Polydactylus sexfilis

gomot striped mullet malet Mugil cephalus

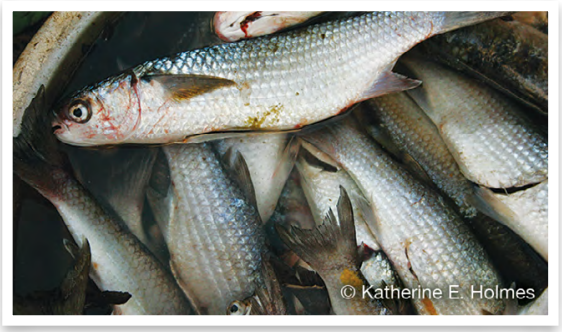

gomot $\sim$ Mugil cephalus

gōrgōrbiliag oriental sweetlips yelo tiklips Plectorhynchus orientalis

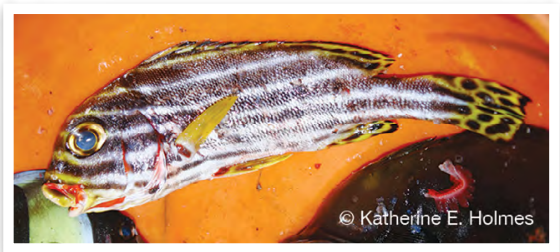

gōrgōrbiliag Plectorhynchus orientalis

kurkurqōl blue-finned triggerfish kaen strongskin

lèl flounder, flatfish flatfis, wansaed fis Family Bothidae, Family Samaridae

lèw (fr.var. löw) generic name for larger wrasses nem we i kavremap ol defren kaen bigfala napoleong Cheilinus spp.

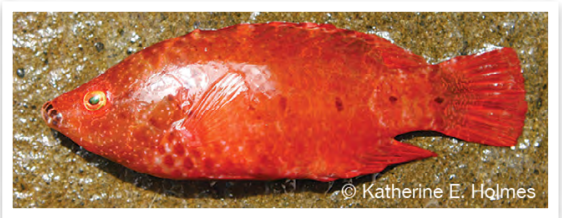

lēw Cheilinus spp. lēw biliag kind of large wrasse kaen bigfala napoleong

lēw mal humphead wrasse $~$ kaen napoleong fis Cheilinus undulatus

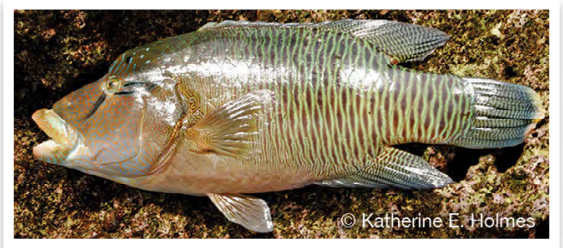

lēw mal Cheilinus undulatus

liaw $1 \cdot$ kind of freshwater fish $\sim$ wan kaen fis blong wota we i no save bigwan 2 - blenny, rockskipper species $\sim$ wan kaen smol fis we i stap jam long ston

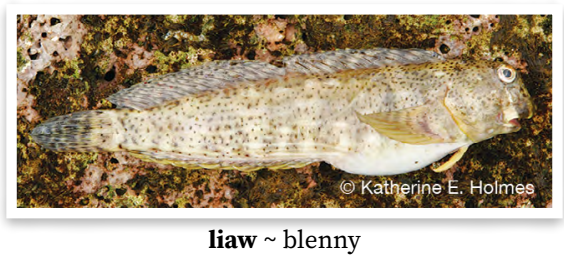

lōat kind of fish wan kaen fis

magalmevesoqötu bigeye $\sim$ wan kaen

fis Family Priacanthidae

magte $_{1}$ stonefish $\sim$ stonfis Family Scorpaenidae

mamat kind of freshwater fish that has large head and eyes. It is light grey and hides in holes in rocks. wan kaen fis blong wota we hem i save bigwan mo ae mo hed blong hem i bigwan. Hem i laet grei mo hem i stap long hol oltaem

mamat serserdiqiat kind of freshwater fish that is silver on its side with a black spot, and light grey on its back wan kaen fis blong wota we hem i silva long saed wetem blak spot. Hem i laet grei long baksaed blong hem. Hem i no save bigwan tumas 
man̄de sabre squirrelfish kaen redfis Sargocentron spiniferum

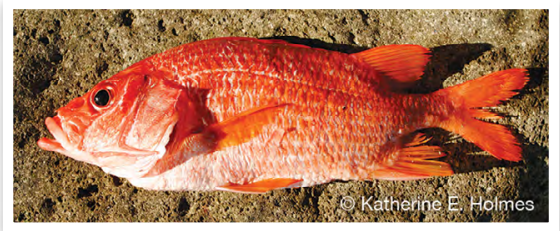

man̄de Sargocentron spiniferum

martat yellowstripe snapper, bluelined snapper $\sim$ kaen pulefis we hem i yelo wetem fo blu laen long hem Lutjanus kasmira

matwiwi cardinalfish wan kaen fis Family Apogonidae

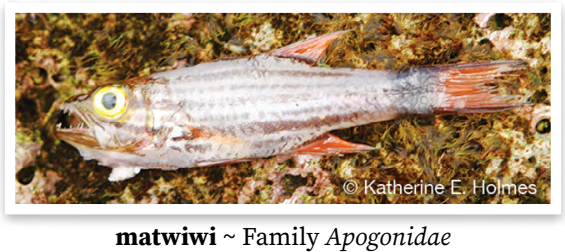

mes fish $\sim$ fis

mesbule kind of fish that lives in fresh water but moves to sea when mature. It is a dull silver and can be found in pairs wan kaen fis we $\mathrm{i}$ bon long wota be taem i bigwan $\mathrm{i}$ go stap long solwota. Hem i silva be i no braet mo i save bigwan. Ol i wokabaot tutu

mesgeben Indo-Pacific sailfish wan kaen fis Istiophorus platypterus

mesmame $\bar{e}_{1}$ pink squirrelfish $\sim$ redfis Sargocentron spp.

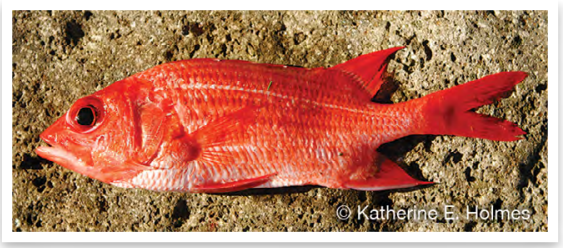

mesmamē $\sim$ Sargocentron spp.

mestalisōr spotted unicornfish kaen strongskin Naso brevirostris

mesteveltiwial copper sweeper $\sim$ wan kaen fis Pempheris oualensis mestēv hogfish kaen fis Bodianus axillaris

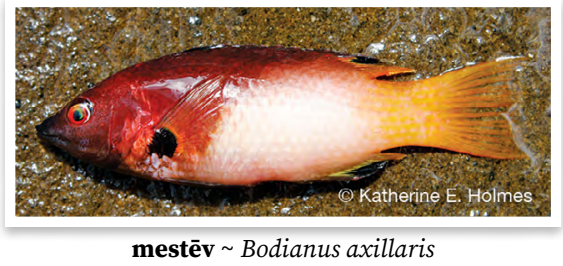

mestiagōsōw black and white snapper

kaen pulefis we hem i waet mo grei Macolor niger

meswelwel fusilier wan kaen fis Family Caesionidae

meteërqōtōn bluespine unicornfish kaen strongskin Naso unicornis

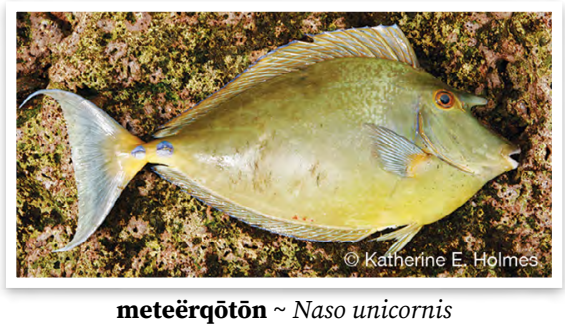

mewērwēr black-tipped grouper kaen los Epinephelus fasciatus

miarbē kind of freshwater fish that is red, and black on its back. It can live in the sea and grows quite large wan kaen fis blong wota we i red mo antap long hem i blak. Hem i save liv long solwota. Hem i save bigbigwan $\mathbf{m o ̄ m} \overline{\mathbf{o}}_{1}$ squaretail grouper $\sim$ kaen los Plectropomus areolatus

mu striped large-eye bream wan kaen fis Gnathodentex aurolineatus

murmur epaulet soldierfish wan kaen redfis wetem bigfala ae Myripristis kuntee

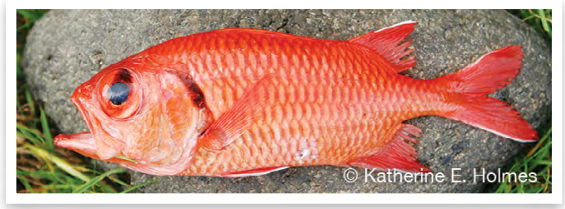

murmur Myripristis kuntee 
murmurbē kind of freshwater fish that is silver with a sharp mouth. It grunts like a pig. It lives in holes in rocks and can also move between fresh and salt water $\sim$ wan kaen fis blong wota we hem i silva mo fes blong hem i sap. Hem i mekem noes olsem pig. Hem i stap long hol mo hem i save stap long solwota

mas goatfish mustasfis Family Mullidae

mas añan goldsaddle goatfish wan kaen mustasfis Parupeneus cyclostomus

mas sarsar yellowfin goatfish, yellowstripe goatfish wan kaen mustasfis we ol i stap wokbaot long grup. Ol i longlongfala mo ol i waet wetem smol dak red spot long saed blong olgeta Mulloidichthys sp.

mas teñtē̄ dash-dot goatfish wan kaen mustasfis Parupeneus barberinus

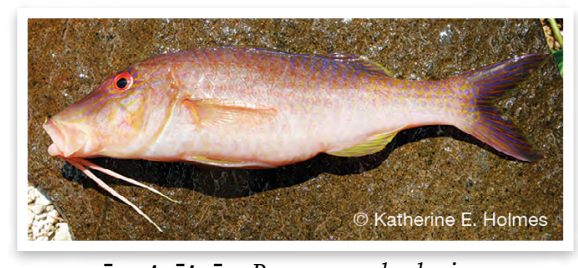

mas ten̄teñ $\sim$ Parupeneus barberinus

mëkër flying fish flaengfis

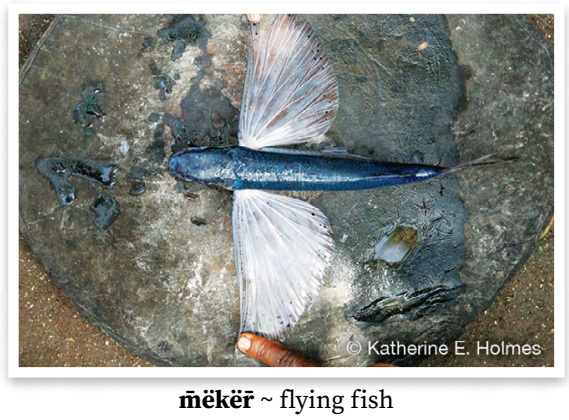

möörögötö pallid triggerfish kaen strongskin Sufflamen bursa non blackfin barracuda $\sim$ sofis Sphyraena genie

ōm humpnose unicornfish kaen strongskin Naso tuberosus

qaēn kind of small freshwater fish. Lays its eggs in the sea in a nest like a spider's nest. When the eggs hatch, they move upstream. They have suckers so they can cling to the rocks to move upstream. A popular eating fish. wan kaen smolsmol fis blong wota we hem i gud blong kakae. Hem i putum eg long solwota wan taem long wan yia mo basket blong eg i olsem blong spaeda. Taem ol pikinini i kamaot ol i klaem folem wota i go antap. Ol i gat samting olsem nawita blong ol i save fas long ston blong klaem i go antap long wota

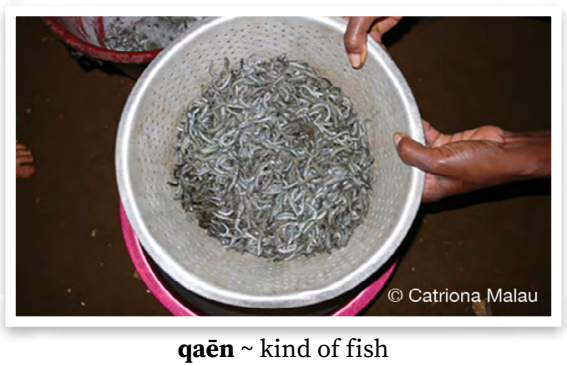

qagar garfish wan kaen fis Family Hemiramphidae

qetmëv surge wrasse wan kaen fis Thalassoma purpureum

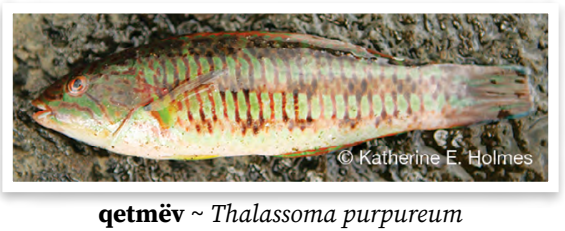

qev humpback snapper $\sim$ kaen pulefis Lutjanus gibbus 
qōl surgeonfish, name covers smaller species of surgeonfish $\sim$ fis we i gat naef, ol smolsmol wan blong hem Acanthurus spp.

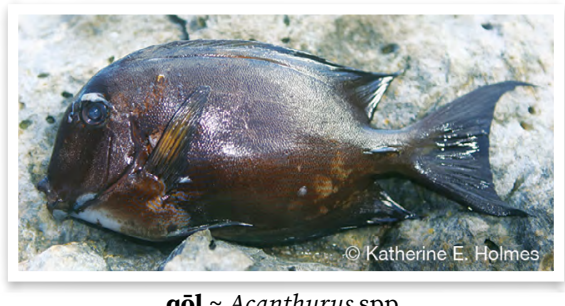

qōl Acanthurus spp.

qōtarō angelfish papiong fis Family Pomacanthidae

qötuqërët big-eye bream wan kaen fis Monotaxis grandoculis

rabiēg bluespotted cornetfish, smooth flutemouth wan kaen longfala fis Fistularia commersonii

$\mathbf{r a k}_{1}$ long-finned drummer wan kaen fis Kyphosus vaigiensis

rēki topsail drummer, Pacific chub, drummer bigbel Kyphosus cinerascens, K. pacificus

ron̄ron̄oqar clown triggerfish $\sim$ kaen strongskin we i gat bigfala waet spot long hem Balistoides conspicillum

rōm 3 - butterflyfish bataflae fis Chaetodon spp.

rō $\mathbf{q}_{1}$ kind of freshwater fish malet blong wota we i save bigbigwan

rōwlav kind of flying fish, larger than other kinds, white with black spots, from deep sea $\sim$ wan kaen flaengfis we hem i bigwan olgeta. Hem i waet be i gat blak spot blong hem. Hem i blong big si blong aotsaed olgeta

röwö bigeye scad kaen bigfala fis blong dipsi Selar crumenophthalmus sarsarale reef lizardfish wan kaen fis Synodus variegatus

sasar $_{2}$ wrasse sop Family Labridae sasargenravarnrōv bluespotted wrasse wan kaen fis Anampses caeruleopunctatus

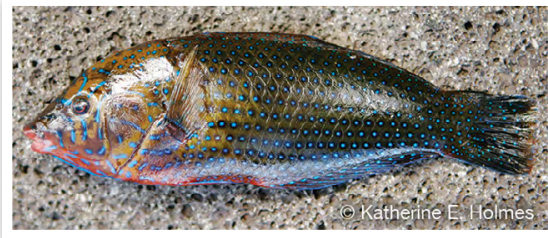

sasargenravarnrōv Anampses caeruleopunctatus

se⿳亠丷厂 white-barred triggerfish, wedgetail triggerfish $\sim$ kaen strongskin Rhinecanthus aculeatus, $R$. rectangulus sewerles several species of hawkfish wan kaen fis Neocirrhites sp., Paracirrhites spp.

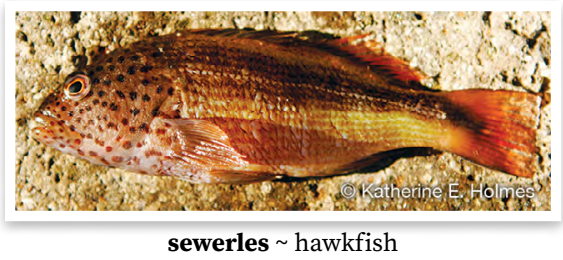

sōm parrotfish, refers to all large species, when they are blue $\sim$ blufis, ol bigwan blong hem Family Scaridae

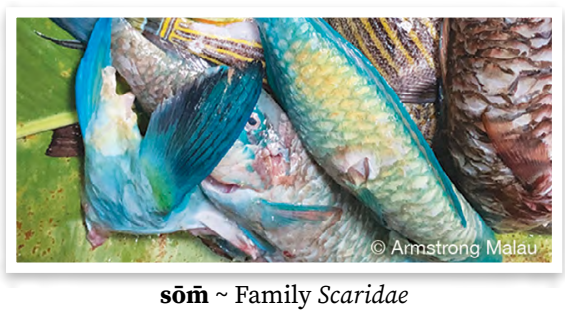

tenmē red bass wan kaen snapa, pulefis Lutjanus bohar

teqesqē spiny squirrelfish $\sim$ kaen redfis Sargocentron spiniferum

terit porcupinefish $\sim$ nilfis Family Diodontidae

terit lam spotted porcupinefish wan kaen nilfis Diodon hystrix

tewesgavēg tailspotsquirrelfish kaen redfis Sargocentron caudimaculatum

til reef needlefish, keeltail needlefish, juvenile needlefish longmaot, ol pikinini o smolsmol kaen blong hem Strongylura incisa, Platybelone argalus 
tiqialdaran̄ran̄ peacock grouper kaen los Cephalopholis argus

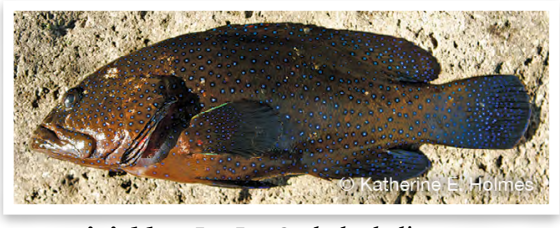

tiqialdarā̄rañ $\sim$ Cephalopholis argus

tiqialq̄ō potato grouper kaen los Epinephelus tukula

tiria lyretail grouper $\sim$ red los Variola louti

tiriakör redmouth grouper kaen los Aethaloperca rogaa

tivtiv ${ }_{1}$ kind of fish wan kaen fish

tivtivnönqet sailfin tang kaen kalakala fis we i gat naef Zebrasoma desjardinii

toqlon kind of flying fish wan kaen flaengfis we hed mo tel blong hem i smol be bel blong hem i bigwan. Hem i stap aotsaed be no tumas

tōqagat blackspot sergeant wan kaen fis Abudefduf sordidus

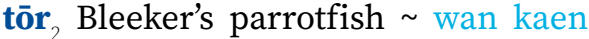
blufis Chlorus bleekeri

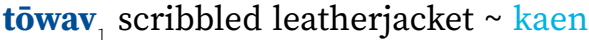
strongskin Aluterus scriptus

tömus rabbitfish piko Family Siganidae

tömus añ kind of rabbitfish kaen piko Siganus sp.

tömus bul kör kind of rabbitfish kaen piko Siganus puellus

tömus kör kind of rabbitfish kaen piko Siganus stellatus

törö ${ }_{2}$ orangeband surgeonfish $\sim$ kaen fis we $i$ gat naef, wetem orenj spot long hem Acanthurus olivaceus

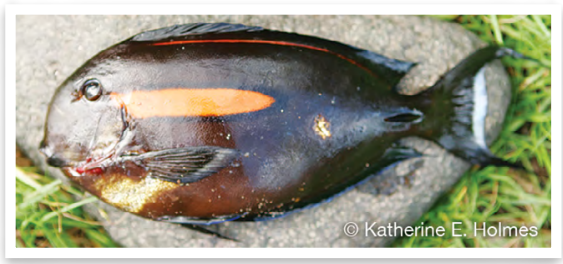

törö Acanthurus olivaceus ut reef needlefish, keeltail needlefish, mature needlefish longmaot, ol bigwan blong hem Strongylura incisa, Platybelone argalus

ut lam kind of needlefish kaen longmaot

ut timiat kind of needlefish kaen longmaot

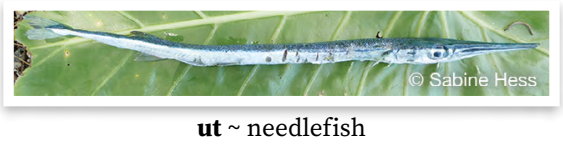

vag surgeonfish, name covers larger species of surgeonfish $\sim$ fis we i gat naef, ol bigwan blong hem Family Acanthuridae, Acanthurus maculiceps A. albipectoralis

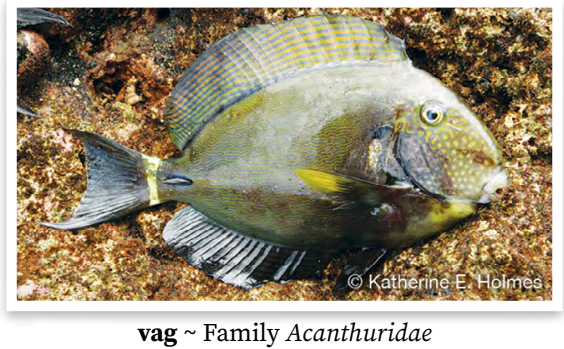

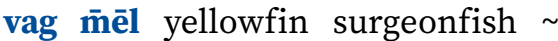
wan kaen fis we i gat naef Acanthurus xanthopterus

vag $\overline{\text { mël }}$ eyestripe surgeonfish wan kaen fis we $\mathrm{i}$ gat naef Acanthurus dussumieri

vērē oyena mojarra, common mojarra silva fis Family Gerreidae

vōlōvōl Klunzinger's wrasse wan kaen smolsmol fis Thalassoma klunzingeri

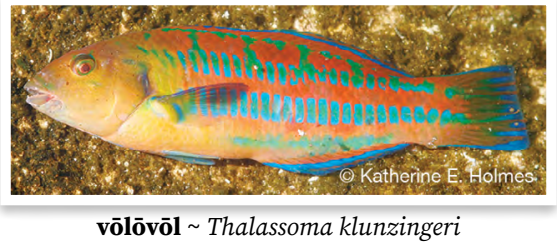

vōlōvōl sōmē Christmas wrasse wan kaen smolsmol fis Thalassoma trilobatum 


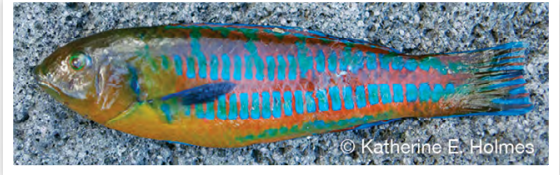

vōlōvōl sō̄̄̄ Thalassoma trilobatum

vōt kind of freshwater fish wan kaen

fis blong wota we hem i no save agensem karen

vurōmōvōt pearly monocle bream wan kaen fis Scolopsis margaritifer walaglē orangespine unicornfish yelo tel strongskin Naso lituratus

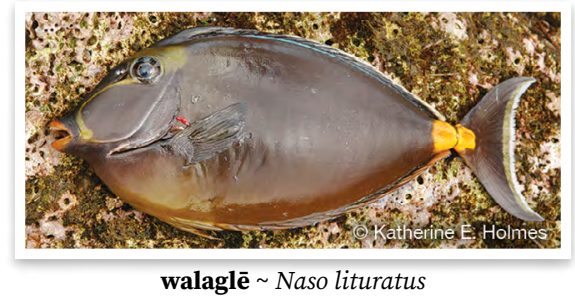

wawasē sweetlip emperor kaen redmaot Lethrinus miniatus

wen̄emërës damselfish species wan kaen fis Family Pomacentridae

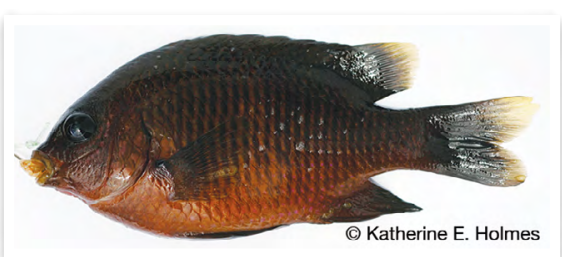

wen̄emërës Family Pomacentridae

wesrē honeycomb grouper smol braon los Epinephelus merra

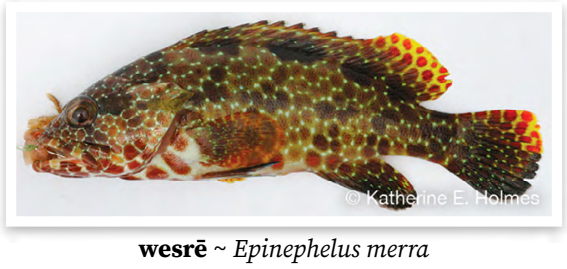

weteltelvet blackside, freckled hawkfish $\sim$ wan kaen fis Paracirrhites forsteri

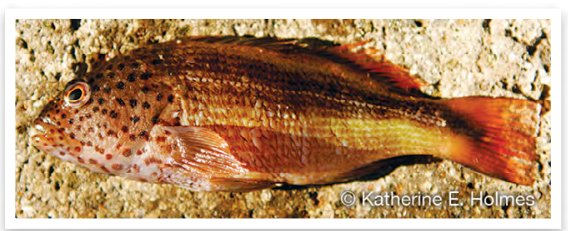

weteltelvet $\sim$ Paracirrhites forsteri

wetevel copper sweeper $\sim$ kaen fis Pempheris oualensis

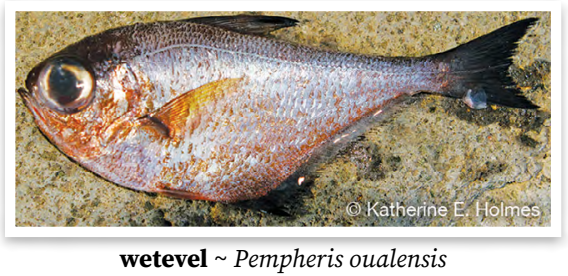

wēduduw (fr.var. wududuw) damselfish $\sim$ wan kaen fis Amblyglyphidodon spp.

wēēwatē blackfin squirrelfish, spotfin squirrelfish $\sim$ kaen redfis Neoniphon spp.

wēgilgialev smallmouth squirrelfish kaen redfis Sargocentron microstoma

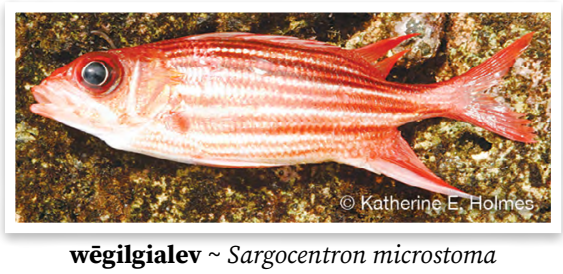

wēlēm immature trevally, jacks and kingfishes smolwan blong karong, taem i bigwan i gat defren nem wēqiar $_{1}$ convict surgeonfish, tang wan kaen fis Acanthurus triostegus

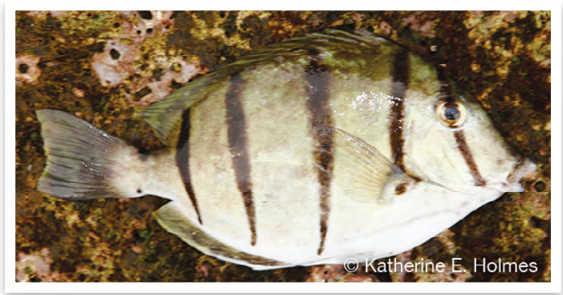

wēqiar Acanthurus triostegus 
wēqitin̄ev samurai squirrelfish kaen redfis Sargocentron ittodai

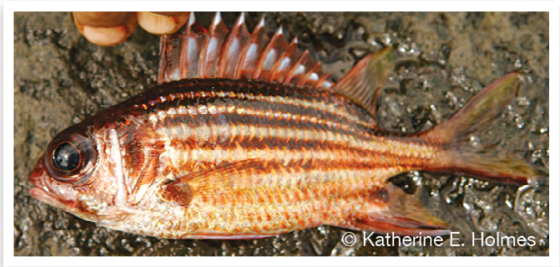

wēqitin̄ev $\sim$ Sargocentron ittodai

wēsilivetel checkerboard wrasse wan kaen smolsmol fis Haliochoeres hortulanus

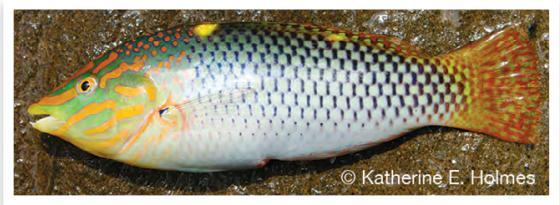

wēsilivetel $\sim$ Haliochoeres hortulanus

wētēvut scorpionfish species kaen fis we i gat nil Family scorpaenidae

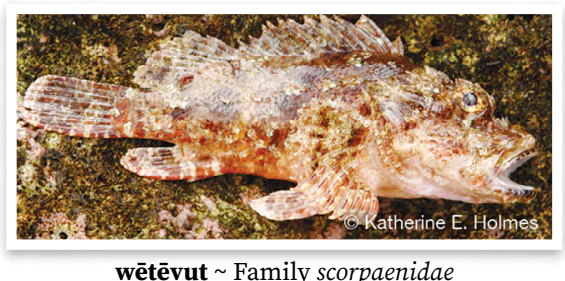

wēvètuo smallmouth squirrelfish

kaen redfis Sargocentron microstoma wiliqliaq fiveband flagtail wan kaen fis Kuhlia mugil

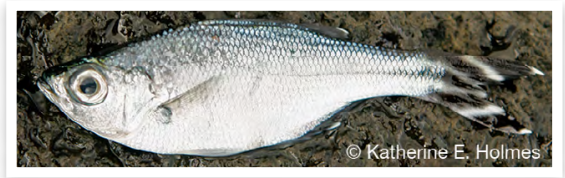

wiliqliaq Kuhlia mugil

wogarēr kind of hawkfish kaen fis

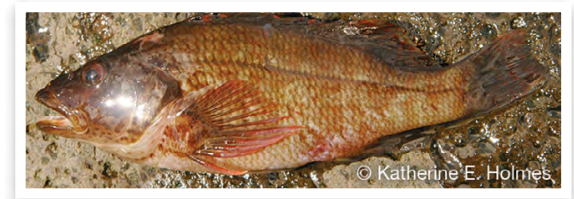

wogarēr $\sim$ hawkfish womalabōs linedcheek wrasse wan kaen fis Oxycheilinus diagrammus

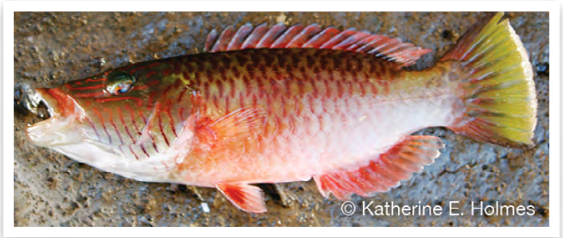

womalabōs Oxycheilinus diagrammus

wotagavēl spotted boxfish fokona, fokonafis Ostracion meleagris

wotoqog stocky hawkfish wan kaen fis Cirrhitus pinnulatus

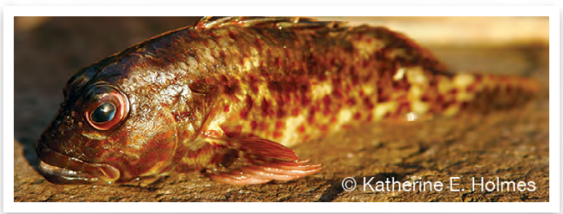

wotoqog Cirrhitus pinnulatus

wotoqtoq $_{2}$ hawkfish $\sim$ wan kaen fis Family Cirrhitidae

wovet spotfin squirrelfish $\sim$ kaen redfis Neoniphon sammara

wowolos Tahitian squirrelfish kaen redfis Sargocentron tiere

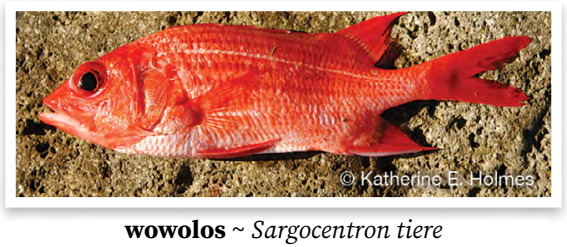

wōnwōn flashflight fish wan kaen fis we ae blong hem i saen olsem toslaet

wōtōqagat seven-bar sergeant, banded sergeant wan kaen fis Abudefduf septemfasciatus

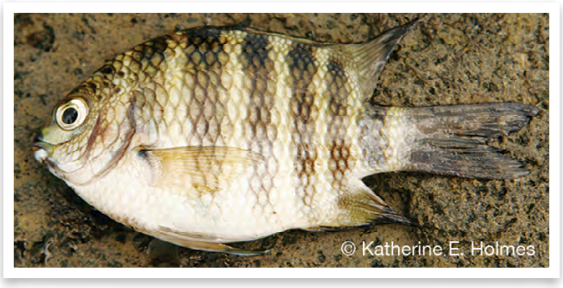

wōtōqagat Abudefduf septemfasciatus 
wōtōwōt pufferfish balongfis, bigbel

Family Tetraodontidae

wōwōsōl long-nosed emperor kaen redmaot Lethrinus olivaceus

wörötuo smallmouth squirrelfish kaen redfis Sargocentron microstoma wösöwunët bird wrasse kaen fis, famle blong blufis Gomphosus varius

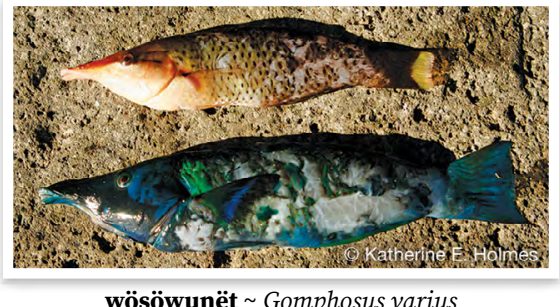

wöturturōrōn̄ bridled monocle bream

$\sim$ wan kaen fis Scolopsis frenatus

wöul (fr.var. wuul) fivestripe wrasse kaen fis, famle blong blufis Thalassoma nigrofasciatum, T. quinquevittatum

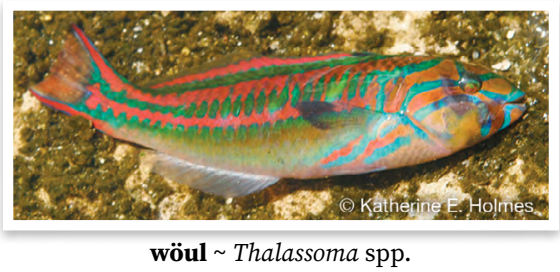

wutu non Spanish mackerel kaen fis Scomberomorus commerson

wutusērēt white-spotted grouper kaen los we i gat waet dot long hem Epinephelus caeruleopunctatus

\section{E4.2 Eels}

\section{marē eel namarae, ilfis}

marē bēluwō kind of freshwater eel that lives in rivers, with a large head, light grey with small spots wan kaen namarae blong wota we hed blong hem i bigwan mo i laet grei wetem ol smolsmol spot. Hem i liv long bigfala wota marē genrō kind of eel that dwells where water meets the sea. It is flat and yellow with black spots wan kaen namarae we i stap klosap long solwota long ples we solwota mo wota i miks. Hem i kakae long tu ples, long wota mo solwota. Hem i flat we i flat mo i yelo wetem blak spot long hem

marē mat kind of freshwater eel, light grey with small spots wan kaen namarae blong wota we hem $i$ laet grei wetem ol smolsmol spot.

marē mes mottled moray wan kaen namarae blong solwota marē qō giant moray wan kaen namarae blong solwota

marē teweswotag starry eel, moray $\sim$ wan kaen namarae blong solwota marē wosgötö girdled reef eel wan kaen namarae blong solwota marē wot kind of freshwater eel, black with white belly, has large eyes. It dwells in swamps and muddy waters wan kaen namarae we baksaed blong hem i blak gud mo bel blong hem i waet. Ae blong hem i bigwan. I stap oltaem long swam mo ples we i gat sofmad

marē wōl kind of freshwater eel, short and silver wan kaen namarae we kala blong hem i silva mo hem i sotwan

mörönërër kind of eel that is thin but long $(150 \mathrm{~cm})$ and speckled brown wan kaen namarae we hemi tintin be longfala mo kala blong hem i braon

tesmērēr kind of freshwater eel, very long, grey with yellow belly and light red tail. It is quite aggressive wan kaen namarae blong wota we hem i save kakae man mo hem i save kamaot hanting long drae ples. Hem i longlongfala mo kala blong hem i grei, andanit i yelo mo fin mo tel i laet red 
vusö black-blotched moray wan kaen namarae Gymnothorax sp.

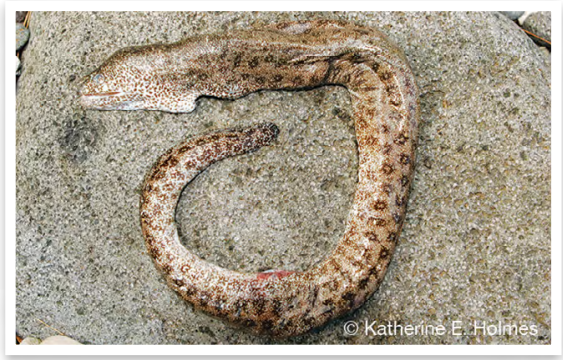

vusö Gymnothorax sp.

vusö ōn painted moray kaen namarae

wutu ōn spotted garden eel kaen namarae

\section{E4.3 Prawns and crayfish}

$\overline{\mathbf{o r}} \mathbf{1}_{1} \mathbf{1}$ - freshwater prawn naora Macrobrachium sp. $\mathbf{2} \cdot$ lobster $\sim$ naora blong solwota Panulirus spp.

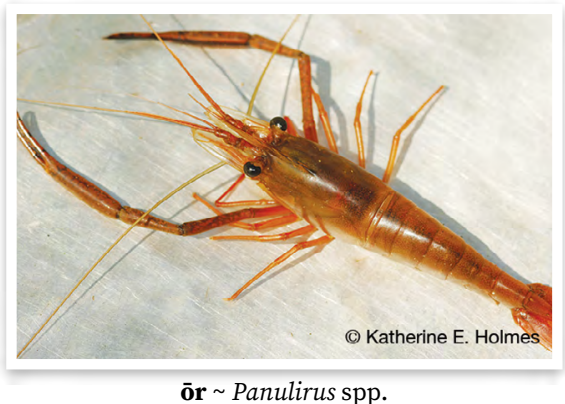

ōr bëlbël kind of freshwater prawn, medium-sized that does not grow large, whitish with spots $\sim$ wan kaen naora we hem i medel saes mo i no save gro bigwan. Hem i waet smol wetem ol spot long hem

òr taban painted rock lobster wan kaen naora blong solwota Panulirus versicolor

qaqet kind of small freshwater prawn wan kaen smolsmol naora

vavam slipper lobster flat naora Parribacus caledonicus
E4.4 Shell fish

gunögōsōw kind of large freshwater shellfish wan bigfala sel blong wota we i stap long saed blong wota matmamē rock shell wan kaen sel blong solwota Thais sp.

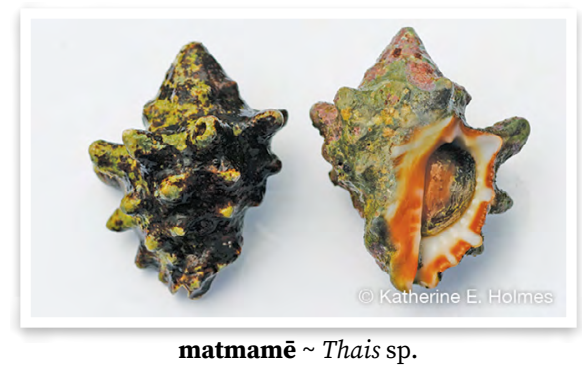

qōbetge common Pacific vase wan kaen sel blong solwota Vasum turbinellus

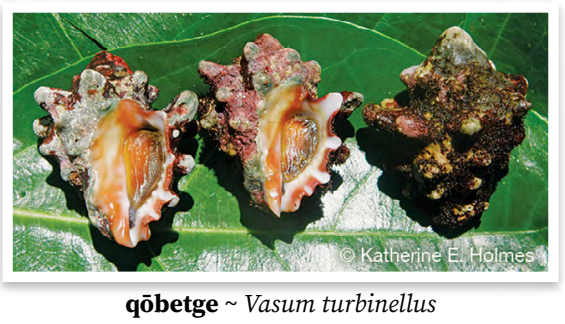

tele clam $\sim$ natalae

tele tur giant clam bigfala natalae, klamsel Tridacna sp.

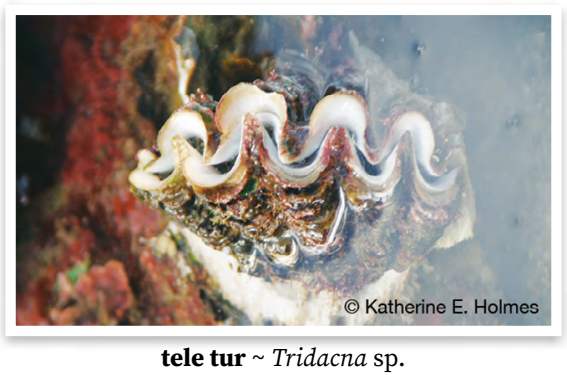

tōw 4 (fr.var. tōw mölum) triton trumpet, conch shell pupu Charonia tritonis 
waakak kind of freshwater mollusc, which can be found in places where the water runs fast $\sim$ wan kaen flat sel blong wota we i stap long ples we wota i save ron strong

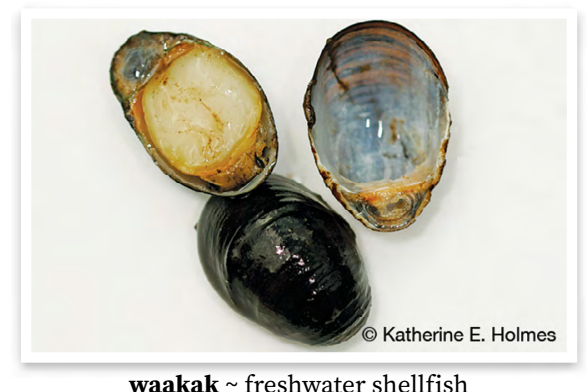

walal top shell troka Trochus niloticus

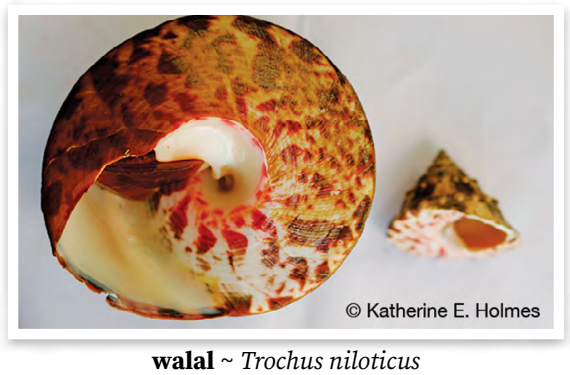

wamatwōn monodont wan kaen sel blong solwota Monodonta sp.

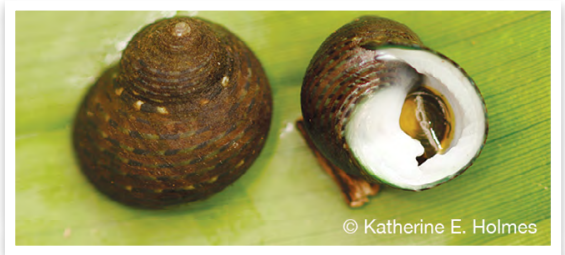

wamatwōn Monodonta sp.

wamase $\overline{\mathbf{e}}_{3}$ abalone $\sim$ kaen sel Haliotis asinina

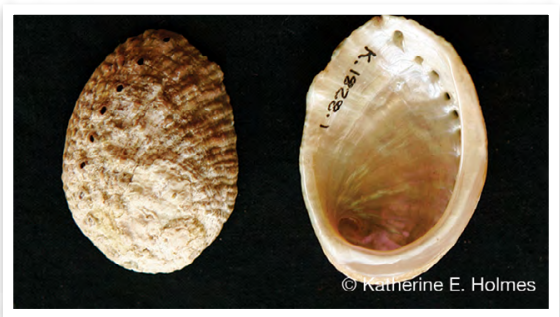

wā̄asē $\sim$ Haliotis asinina watagōgōn kind of gastropod shellfish

wan kaen nasese we i stap long ston

watawlētlēt Pacific star shell wan kaen sel blong solwota Astraea haematraga

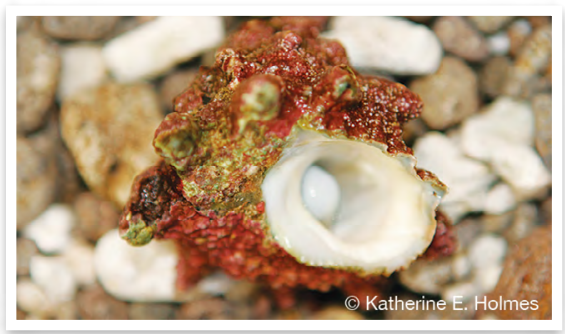

watawlētlēt Astraea haematraga

weger kind of gastropod shellfish, generic term which covers a number of bivalve and limpet species grup blong sel blong solwota, kaen sel we ol i yusum blong skrasem kakae mo smutum pandanas

weger dun sunset shell wan kaen sel blong solwota

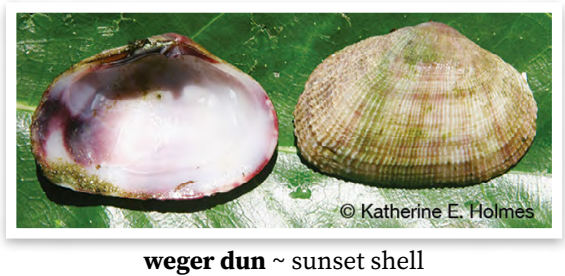

weger mel common turtle limpet paua Cellana testudinaria

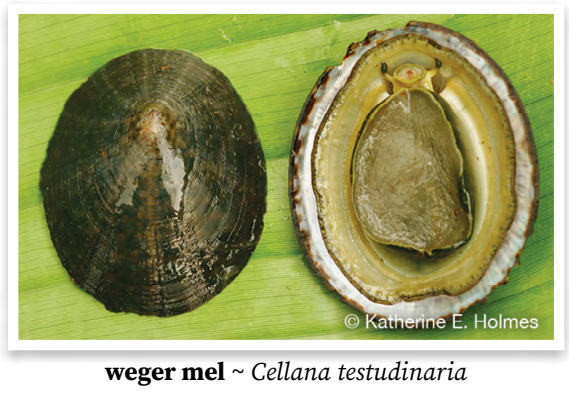

weger sōl kind of small shellfish which is found on the sand $\sim$ kaen smolsmol selfis we i stap long sanbij 
weger ta Pacific sugar limpet wan kaen sel blong solwota Patelloida saccharina

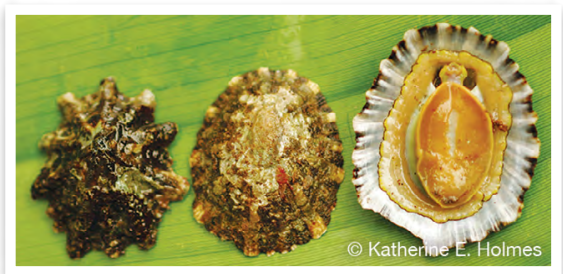

weger ta $\sim$ Patelloida saccharina

weger tur ${ }_{1}$ pen shell wan kaen sel blong solwota Pinna bicolor

weger tur 2 Pacific asaphis, sunset shell wan kaen sel blong solwota Asaphis violascens

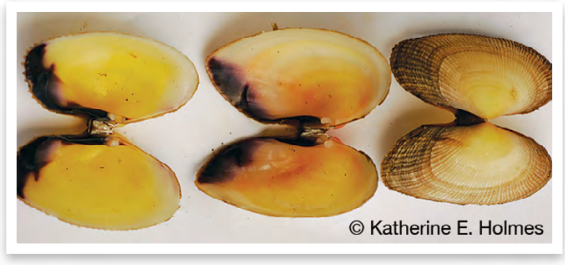

weger tur $\sim$ Asaphis violascens

weqet kind of freshwater shellfish that has spines that can stick into one's feet and break off if trodden on wan kaen nasese we i stap long wota mo i save stikim man

weswesak filamentous horse conch, used in the past to drill holes in canoe for binding canoe wan kaen sel blong solwota, sel we yu save yusum olsem dril, bifo ol i yusum blong mekem hol long kenu Pleuroplaca filamentosa

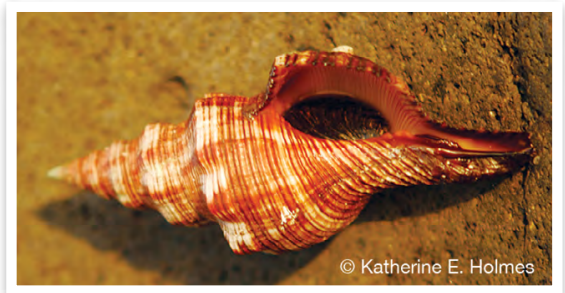

weswesak Pleuroplaca filamentosa weterōw smooth moon turban wan kaen sel blong solwota Lunella cinerea

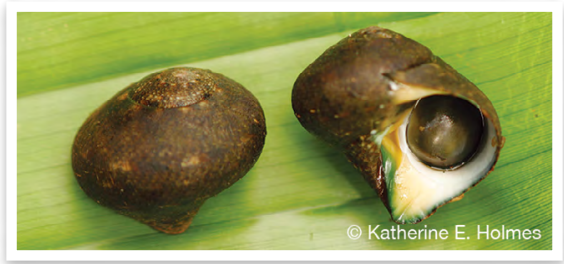

weterōw $\sim$ Lunella cinerea

wēgim giant clam that can move natalae we i save wokabaot Tridacna sp.

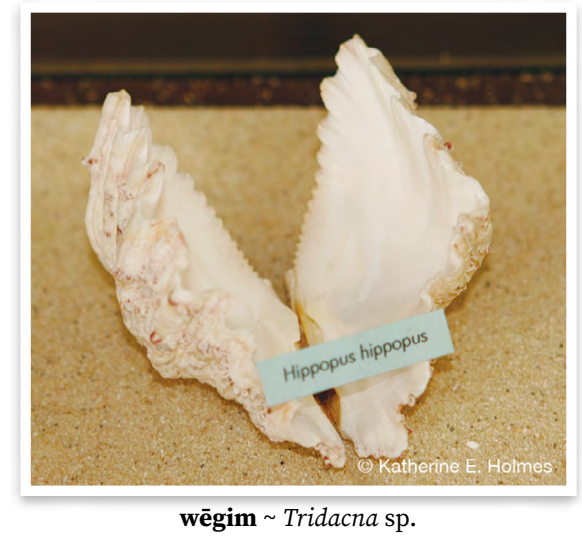

wēsēm olive shell wan kaen sel blong solwota Family Olividae
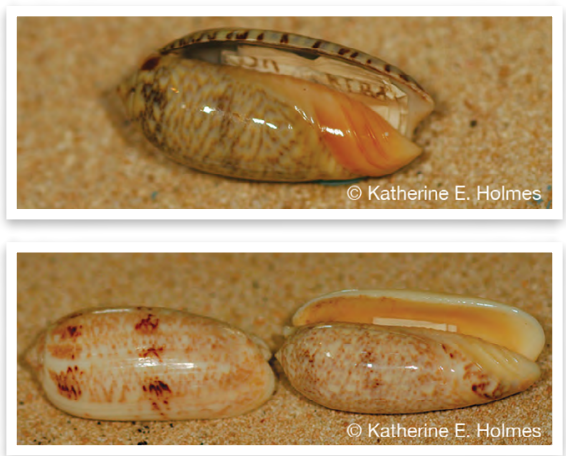

wēsēm Family Olividae

wēsēs generic name for sea snails, types of gastropod with snail type shells ol kaen nasese blong solwota we i fas long ston o rif 
wēsēs bē kind of freshwater shellfish that is round and black and red inside wan kaen sel blong wota we i raon mo baksaed blong hem i blak mo insaed long sel i red

wēsēs biēg $\mathbf{1} \cdot$ harp shell wan kaen sel blong solwota Family Harpidae 2 - mitre shell wan kaen sel blong solwota Purpura sp.

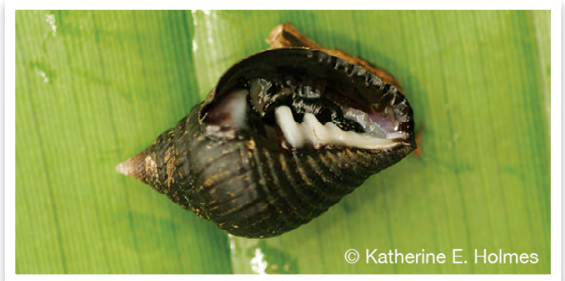

wēsēs biēg Purpura sp.

wēsēs malau kind of turban shell wan kaen bigae blong solwota Turbo crassus

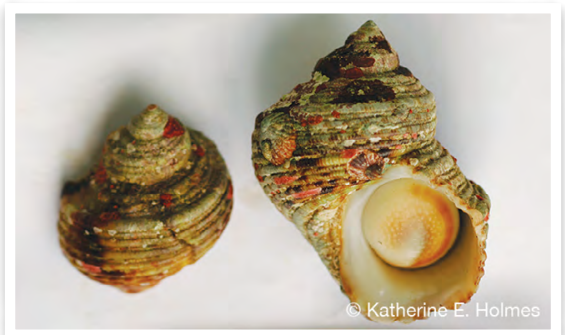

wēsēs malau Turbo crassus

wēsēs man tapestry turban wan kaen sel blong solwota Turbo petholatus

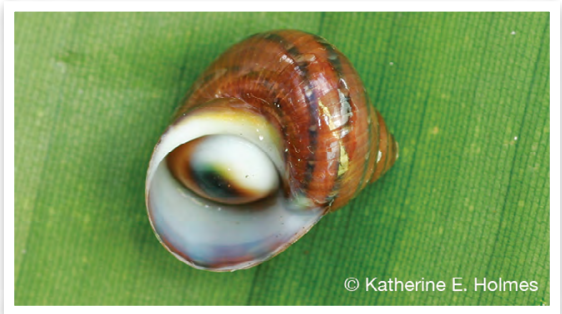

wēsēs man Turbo petholatus

wēsēs nōnōm kind of freshwater shellfish that can only be seen at night wan bigfala sel blong wota we i kamaot long naet nomo

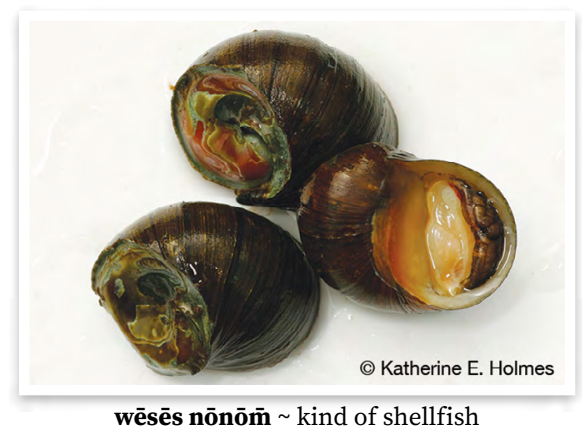

wēsēs tan̄ov great green turban grinsnel Turbo marmoratus

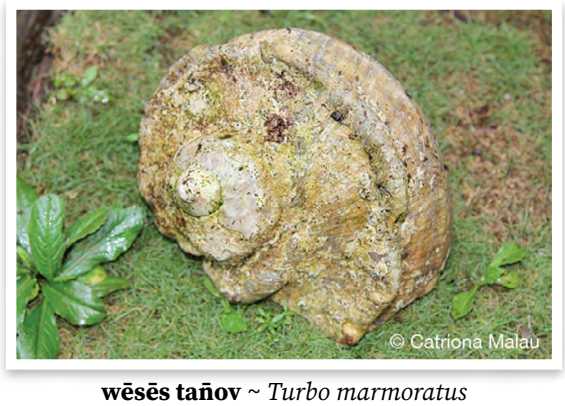

wēsēs vet rough turban wan kaen bigae blong solwota Turbo setosus

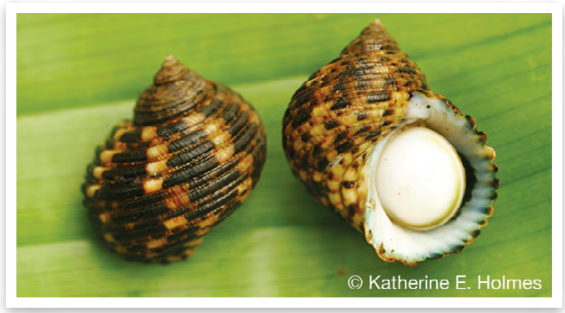

wēsēs vet $\sim$ Turbo setosus

wēsēs wōmalak kind of turban shell wan kaen bigae blong solwota Turbo sparverius

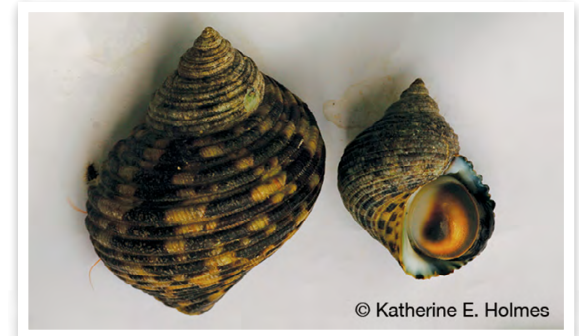

wēsēs wōmalak Turbo sparverius 
wētēqēdur auger shell wan kaen sel blong solwota Terebra spp.

wētēwil (fr.var. wētiwil) nerite nasese Family Neritidae

wētēwil bēt plicate nerite kaen nasese Nerita plicata

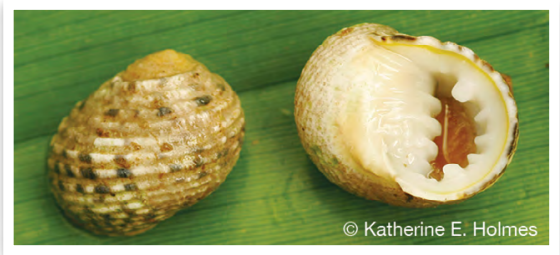

wētēwil bēt $~$ Nerita plicata

wētēwil kör waved nerite kaen nasese Nerita undata

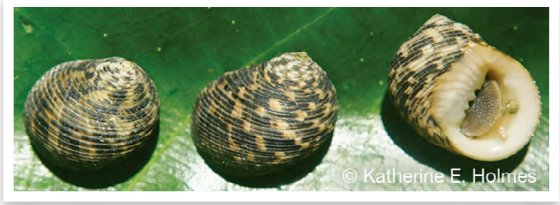

wētēwil kör Nerita undata

wētēwil mëv maximum nerite kaen nasese we i stap long rif long ples we solwota i no stap kasem Nerita maxima

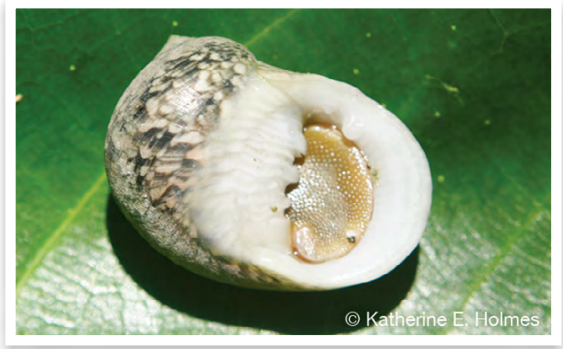

wētēwil mëv Nerita maxima

wètēwil serōn kind of nerite kaen nasese Nerita polita

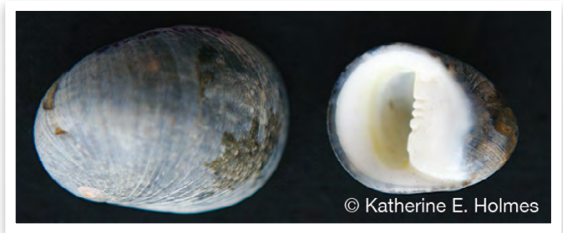

wētēwil serōn $~$ Nerita polita widiañ $1 \bullet$ serpent's head cowrie wan kaen kaorisel Cypraea caputserpentis

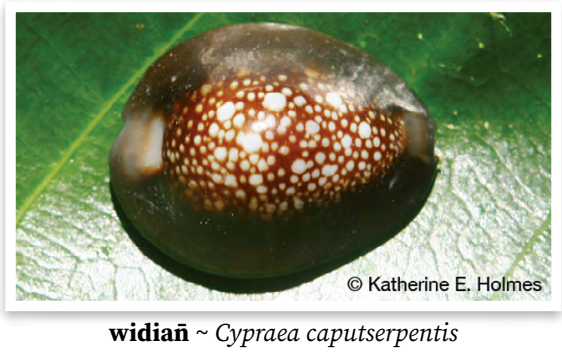

woswos kind of top shell famle blong troka Tectus pyramis

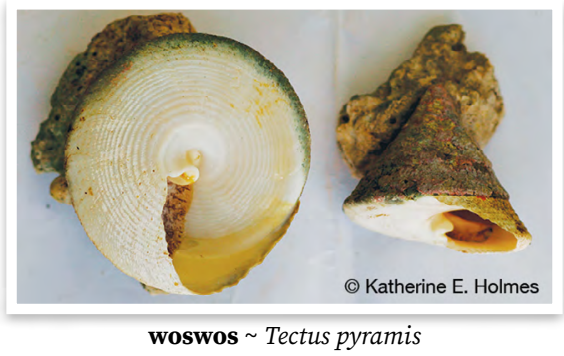

wōgōlgōl cone shell wan kaen sel blong solwota, konsel Conus spp.

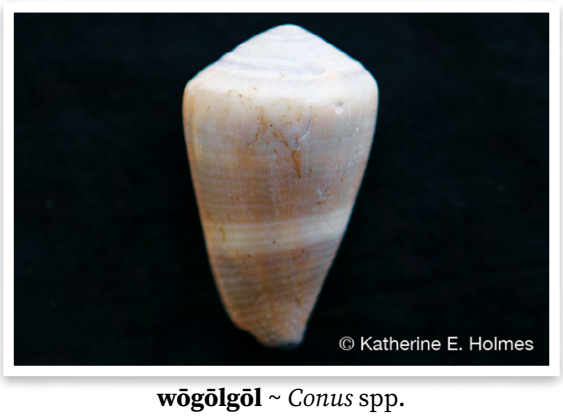

wōrō sel olsem troka be i smol mo waet Astraea kesteveni

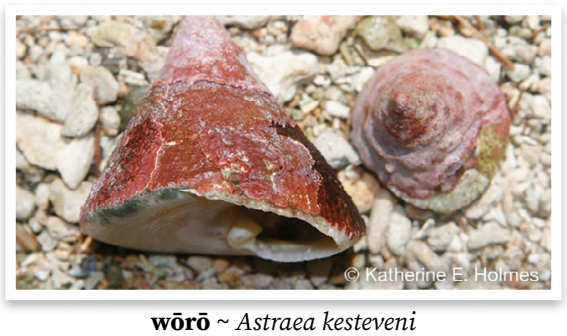


wōwlan cowrie kaorisel Family Cypraeidae; Cypraea mauritiana

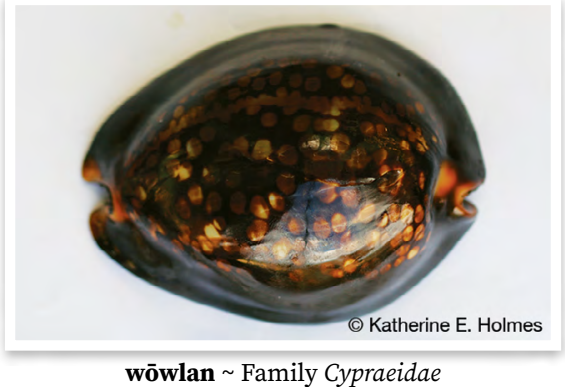

wölubus corded turban wan kaen bigae blong solwota Turbo sparverius (?)

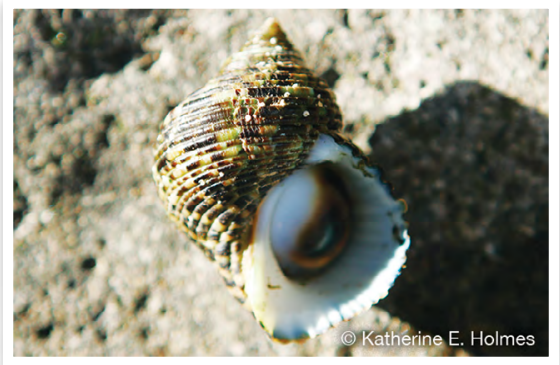

wölubus Turbo sparverius (?)

wöqörö kind of freshwater shellfish which is found in muddy areas wan kaen sel blong wota we i stap long sofmad

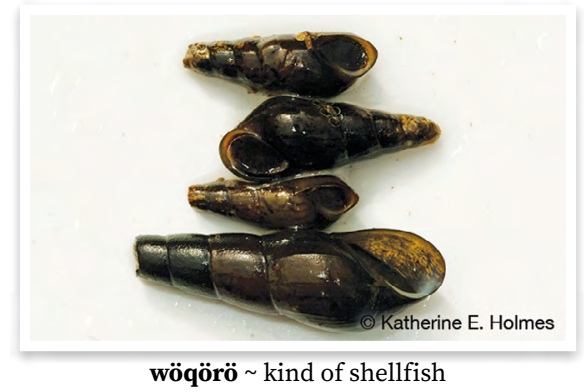

wörön̄ötöwö aculeate rock-shell wan kaen sel blong solwota Thais aculeata
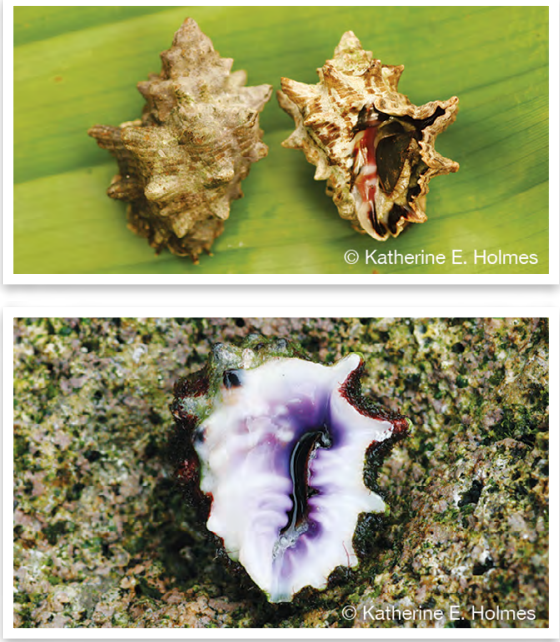

wörön̄ötöwö Thais aculeata

wösöm kind of gastropod shellfish wan kaen sel blong solwota

wösusumàmà (fr.var. susum̄almal) maculated top shell wan kaen selfis we i olsem troka be i raon mo sep blong hem i olsem titi blong wan gel Trochus maculatus

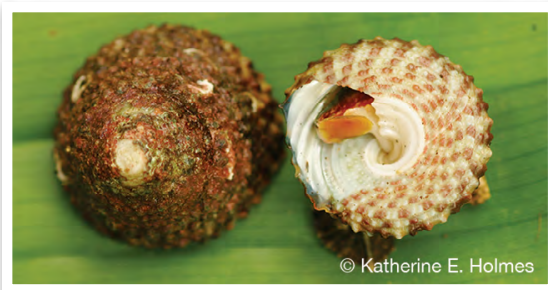

wösusū̄almāal Trochus maculatus

wutumet drupe shell wan kaen sel blong solwota Drupa morum, Drupa grossularia

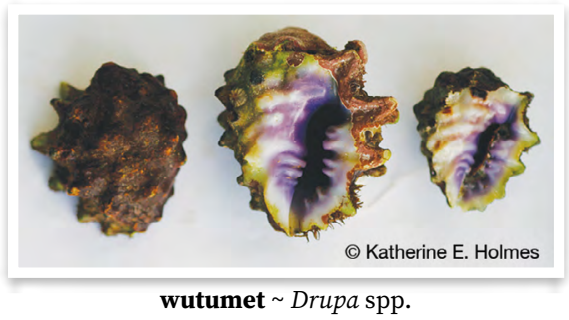




\section{E4.5 All other sea and shore life}

bēw 1 1 kind of slug that is brown slag, samting olsem snel be i nogat sel blong hem $\mathbf{2}$ - kind of sea slug samting olsem besdemea we i stap long solwota

ërlam sea fan samting blong solwota we i luk olsem wan fan Plexauridae spp.

malwērēt brittle star kaen stafis we bodi i smol mo ol leg i longwan, mo i gat ol smolsmol nil long hem

me 1 - banded sea snake, banded sea krait sisnek we hem i blak mo waet Laticauda colubrina

menek $\mathbf{1} \cdot$ squid $\sim$ nawita $\mathbf{2} \cdot$ cuttlefish $\sim$ nawita, katelfis

on kind of large octopus, can be taller than man, with a big head bigfala nawita we i gat bigfala hed

sernönqet kind of sea urchin with sharp spines samting blong solwota we i olsem sel mo i gat ol sap nil long hem Family Diaematidae

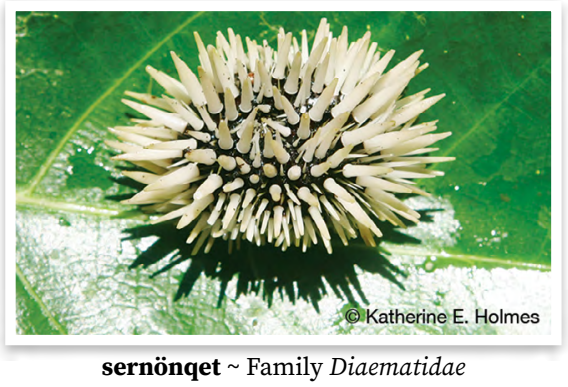

sëkër reef, coral, refers both to an area of reef and to coral heads that comprise the reef $\sim$ rif

un palolo, sea worm, marine annelid $\sim$ palolo, siwom Palola viridis

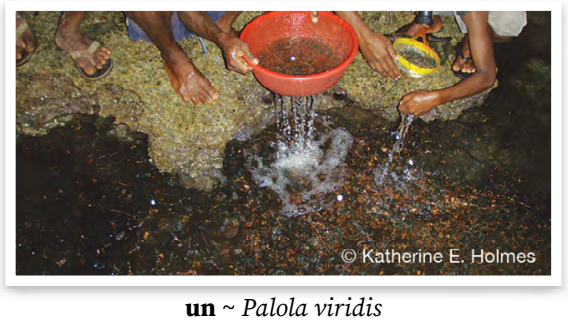

un gal male of the species Palola viridis, distinguished by its light brown colouring palolo wom we hem i man wan, we hem i laet braon

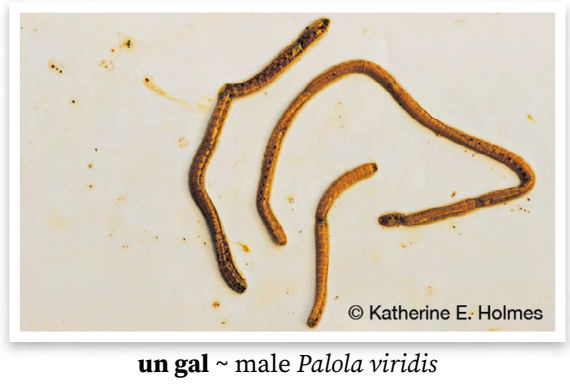

un lam female of the species Palola viridis, distinguished by its deep blue-green colouring palolo wom we hem i woman wan, hem i dak mo i blu o grin

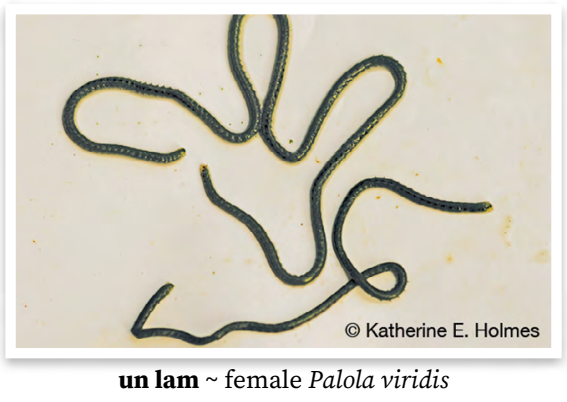

vinraq dead coral rif we i ded finis wadas kind of sea urchin with thick blunt spines $\sim$ kaen sel blong solwota we i gat nil long hem be hem i no sap Family Cidaridae

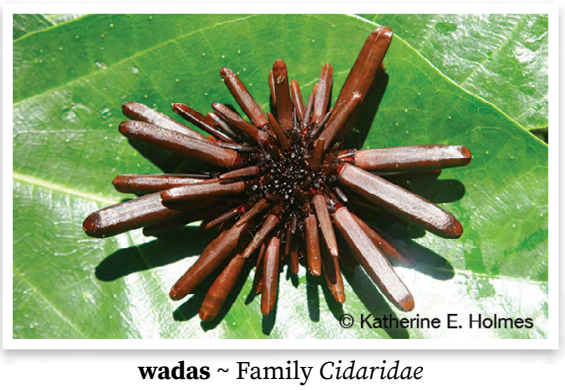

weles coral, both live and dead rubble $\sim$ korel, olsem pat blong rif o we i ded finis 
wēbēbēs barnacle kokias we i fas long ston o botom blong sip

wērēt octopus nawita

wētēltēliriaw snake sea cucumber

wan samting olsem besdemea Synapta maculata

wètēv nautilus notilis, kaen sel blong solwota Nautilus pompilius

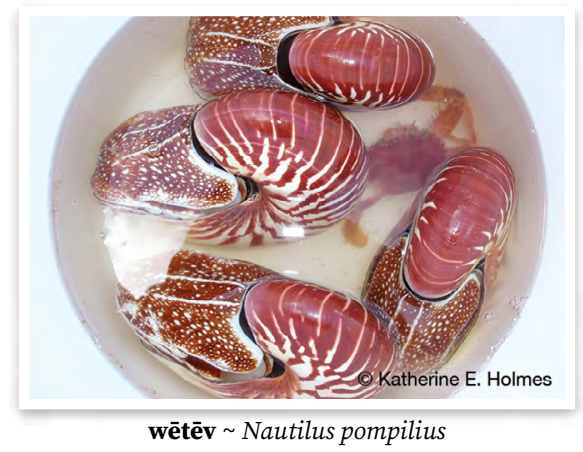

widiar 2 - phosphorescence in the sea $\sim$ ol smolsmol samting we i stap saen long solwota long naet

womal coral head korel, pat blong rif insaed long solwota

wotaqlislis unidentified variety of marine worm. The morphology of this variety is considerably different from that of those identified as Palola sp. and it is likely that they are from a different family. They are short, black on top, red on the sides, and white on the underside. kaen wom blong solwota we hem i defren lelebet long palolo. Hem i sotsotfala, i blak antap, red long saed blong hem, mo bel blong hem i waet.

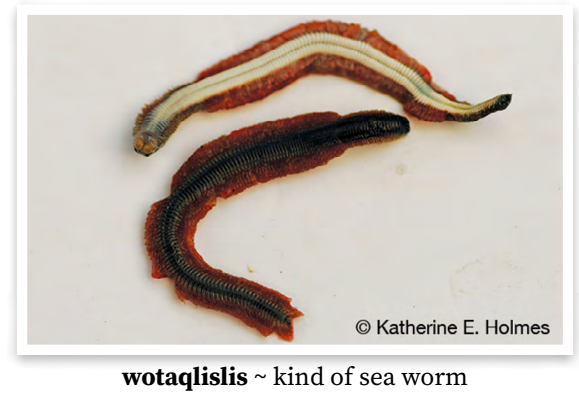

wōqōqō beche de mer, sea cucumber besdemea, si kukamba Family Holothuriidae

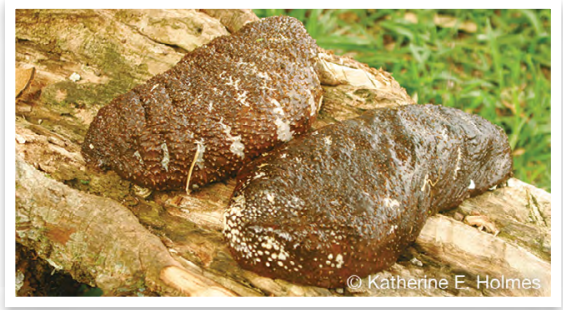

wōqōqō Family Holothuriidae

wögörtö spiny chiton strongbak Family Chitonidae

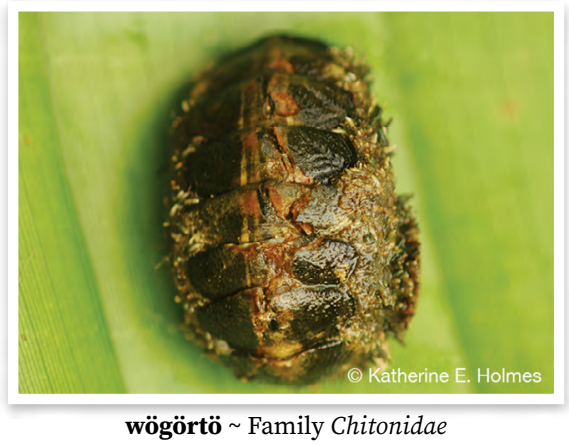

wömönmönösot unidentified variety of marine worm. The morphology of this variety is considerably different from that of those identified as Palola sp. and it is likely that they are from a different family. They are short in comparison with the palolo and light yellow-orange in colour. kaen wom blong solwota we hem i defren lelebet long palolo. Hem i sotsotfala mo hem i laet red.

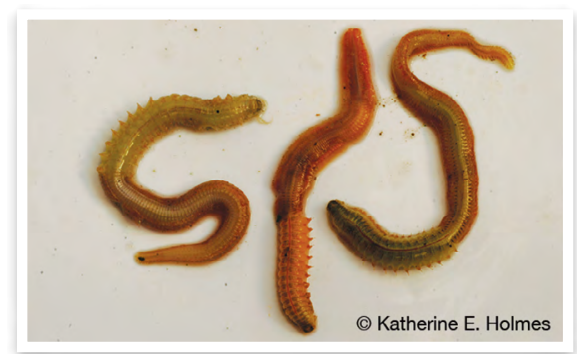

wömönmönösot kind of sea worm 
E5 Crabs and hermit crabs

dēr coconut crab krab kokonas Birgus latro

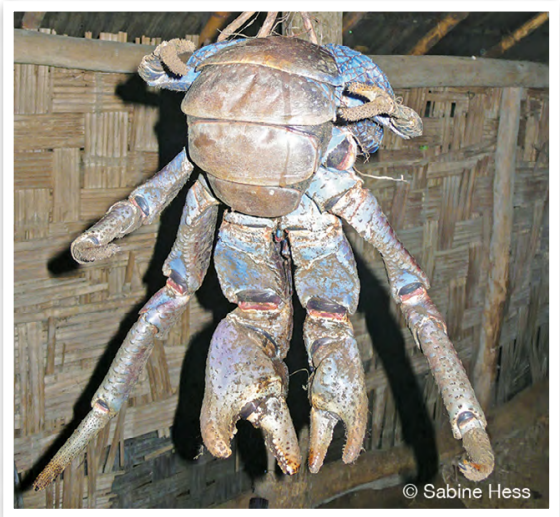

dēr Birgus latro

gamar mottled lightfoot, rocky shore crab wan kaen krab we i stap long so Grapsus albolineatus

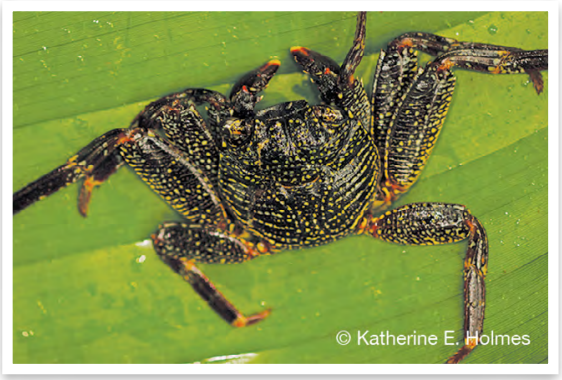

gamar Grapsus albolineatus

giav crab krab

giav kukut sargassum crab wan kaen krab blong solwota Family Grapsidae

giav matrōrōw kind of crab with big eyes, blue back and white underside. Found in the bush or shore, close to the sea wan kaen krab we ae blong hem i bigbigwan mo baksaed blong hem i blu, front i waet. Hem i stap long bus o so be klosap long solwota giav mërës mottled lightfoot crab wan kaen krab we i stap long so Grapsus albolineatus giav ōwōw spanner crab wan kaen krab blong solwota Ranina ranina giav semetöv kind of crab that dwells in holes in rotten trees in the water. It is white and light brown wan kaen krab we i stap insaed long wota insaed long hol blong wud. Hemi lelebet waet mo laet braon giav sēvsēv kind of crab wan kaen krab giav sōsō kind of freshwater crab which lives in swamps $\sim \mathrm{krab}$ Kaledoni

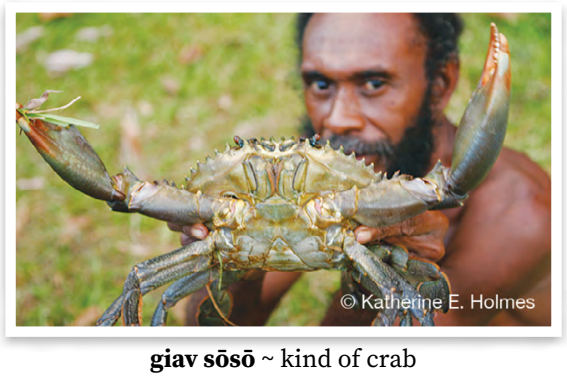

giav tamal mottled lightfoot crab wan kaen krab we i stap long so Grapsus albolineatus

giav vaw kind of reef crab with red spots on shell wan kaen krab we i stap long rif we i gat red dot long baksaed Carpilius maculatus

giav vet kind of shore crab wan kaen krab we i stap long so Plagusia dentipes

giavēdun land crab (with hairy legs) wan kaen krab we hem i blak mo hem i gat tumas hea blong hem. Hem i stap long drae ples be hem i go long solwota taem $i$ gat eg

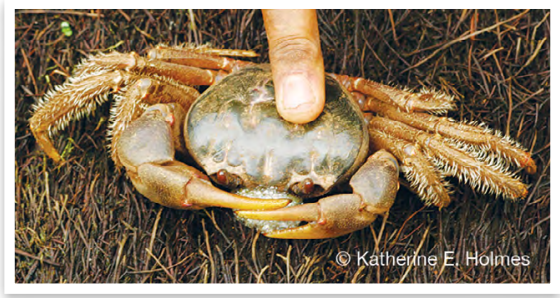

giavēdun kind of crab 
gōdōw red-eyed crab wan kaen krab blong solwota Eriphia sebana

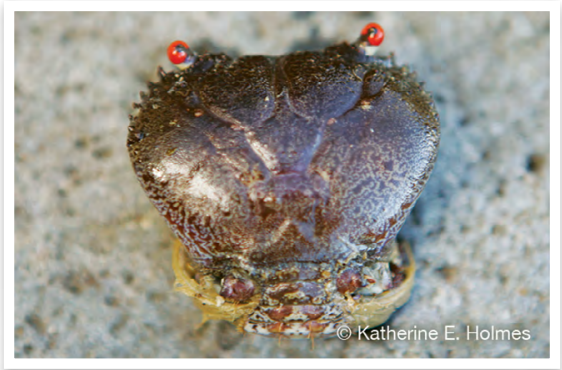

gōdōw Eriphia sebana

görum black land crab that is red when cooked, lives in holes in trees or in the ground wan blak krab we i stap long bus insaed long wud o hol long graon. Taem yu kukum hem i red Gecarcinus quadratus

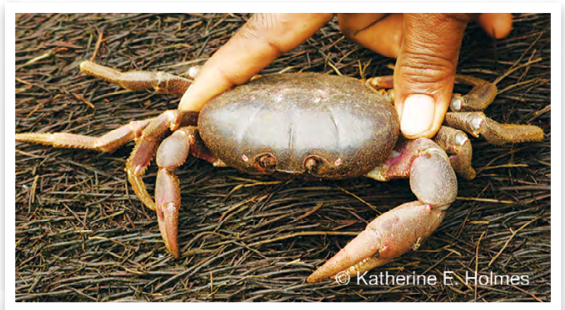

görum Gecarcinus quadratus

götö ${ }_{1}$ hermit crab nakato

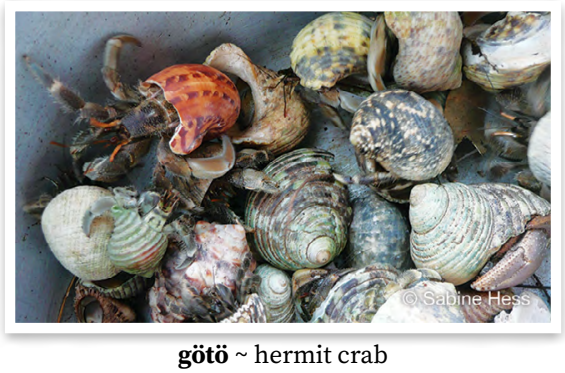

götö mamē kind of land hermit crab $\sim$ wan kaen nakato we i stap nomo long drae ples

götö riam takak kind of black hermit crab found in the bush wan kaen blak nakato blong bus götö sërsër kind of small hermit crab that lives in the sea wan kaen smol nakato we i stap insaed long solwota

sursal land crab (with hairy legs) wan kaen krab we hem i blak mo hem i gat tumas hea blong hem. Hem i stap long drae ples be hem i go long solwota taem i gat eg Gecarcinidae sp.

tēbar kind of crab, white, which dwells by the sea where there is sand and mud $\sim$ wan kaen waet krab we i stap long solwota long ples we i gat sanbij mo sofmad

tigian kind of sea crab that is black with claws that are white underneath $\sim$ krab blong solwota we hem i laet blak mo ol fingga blong hem ol i waet andanit

wēgēriv ghost crab wan kaen krab blong solwota Ocypode ceratophthalma

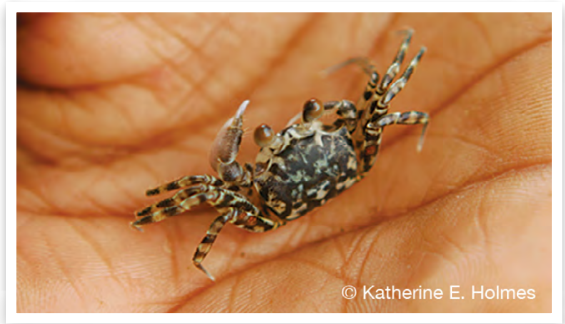

wēgēriv Ocypode ceratophthalma

wēgilgialnaw fiddler crab kaen krab Uca sp.

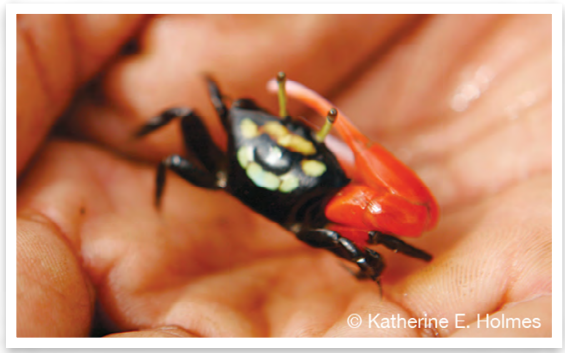

wēgilgialnaw Uca sp.

wōg kind of freshwater crab wan kaen krab blong wota 
wōlōrōr kind of small crab found on the sand, red with large claws wan kaen smol krab blong sanbij we kala blong hem i red mo tut blong hem i bigwan

wökutökut kind of sea crab wan kaen smol krab blong solwota

E6 Insects, other land arthropods, grubs

$\mathbf{b}_{\mathbf{e}} \mathbf{w}_{1} \mathbf{1} \cdot$ kind of slug that is brown slag, samting olsem snel be i nogat sel blong hem $\mathbf{2}$ - kind of sea slug samting olsem besdemea we i stap long solwota

bōñ cicada wan kaen bebet we hem i singaot long naet

bōrō̄n kind of beetle shaped like a turtle with hard wings and a strong smell wan kaen bebet we wing blong hem i strong mo sep blong hem i olsem totel. Hem i sting

bustavēl kind of colourful, shiny beetle wan kaen bebet we wing blong hem i strong mo i kalakala mo i saen

busumat kind of insect kaen bebet

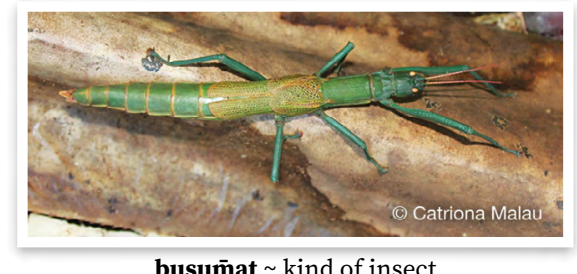

gatala web bed blong spaeda gateli maraw spider web bed blong spaeda

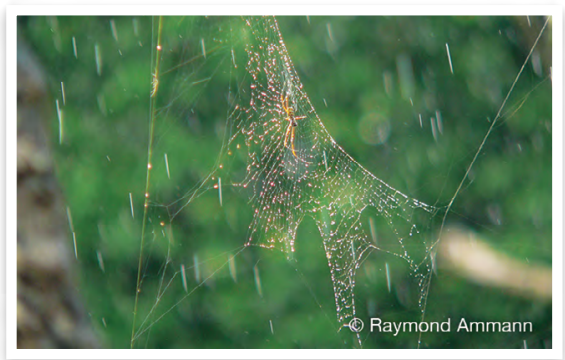

gateli maraw spider web gen $_{2}$ fire ant $\sim$ blakanis Solenopsis geminata

gōsōs insect that damages yam and taro and Hong Kong taro bebet we i stap kakae yam mo taro mo Fiji taro Papuana uninodis

lan̄ fly flae

lan̄ talōbō blowfly bluflae

lañ tanō kind of small fly that is found by freshly dug ground, they cause damage to fruits like oranges wan kaen smol flae we i kamaot taem yu digim niufala graon; ol i spolem ol frut olsem aranis

lan̄ vivis small black fly smol blak flae

lēs nit, louse egg eg blong laos

magal ant $\sim$ anis

magal tutun kind of large, reddish, biting ant, produces painful bite wan kaen bigfala anis we hem i hafred. Taem i kakae man i soa mo i hot wantaem

maraw spider spaeda

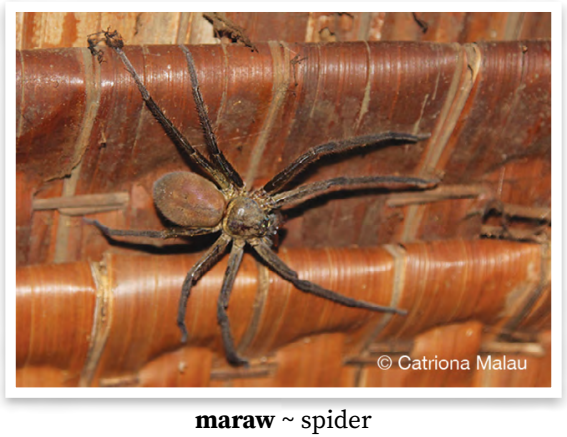

mèlēs worm wom

mēlēstenten kind of insect that is similar to a cicada, both in the way it looks and noise that it makes wan kaen bebet we hem i wokabaot long graon mo hem i save jam. Hem i singaot oltaem

matètē kind of small spider. When you touch its web, the spider shakes $\sim$ wan kaen smol spaeda. Kaen we taem yu tajem web blong hem i seksek 
nem 2 mosquito moskito

nem biliag kind of mosquito that is black with grey spots wan kaen moskito we hem i blak wetem grei spot

nem talöqön kind of mosquito that is brown and comes out at night wan kaen moskito long naet we hem i braon

$\overline{\mathbf{o}} \mathbf{1}_{2}$ maggot $\sim$ maget

qetsōs kind of insect like a termite but larger wan kaen bebet we hem i olsem waetanis be i bigwan lelebet

qētēt termite, white ant waetanis

$\mathbf{q} \overline{\mathbf{o}}_{2}$ type of insect, large and black, that bites people and fights with cockroaches $\sim$ bebet we i save kakae man. Hem i blak mo bigfala mo hem i save faetem kakros

rōm $\mathbf{1}$ - butterfly bataflae

rōm timiat kind of big, black butterfly with white dots wan kaen bataflae we hem i bigbigfala mo hem i blak wetem waet dot

sinav kind of insect that is like a cockroach but small wan kaen bebet we hem i olsem kakros be i smolsmol. Ol i laek blong stap antap long faea from we ol i laekem hit mo smok blong faea

tebedēmēēl centipede $\sim$ milpat Order Chilopoda

tōbulënqet kind of insect like a dragonfly wan kaen bebet olsem dragonflae be i smolsmol mo i waet. Taem yu tajem i save jam longwe

vun $_{2}$ kind of insect that destroys yam kaen bebet we i kakae yam

weswes piles of fecal pellets, probably from a type of termite, appearance is like dried yeast, but slightly larger, pest unidentified and not seen, only the deposit $\sim$ hip blong ol smolsmol raon samting we i kamaot long wud taem wan kaen bebet i kakae weverbōn kind of moth that comes out in the early evening, at dusk, and makes a loud buzzing noise with the beating of its wings kaen bataflae blong naet we hem i kamaot taem tudak i kam, mo i mekem noes wetem wing blong hem

weviat type of insect that lives in wood, edible bebet we i stap long wud we man i save kakae

wēgēngēndilo kind of insect like a grasshopper but smaller, found around stones by the sea kaen bebet we hem i olsem grashopa be i smol mo i stap long ol ston long saed blong solwota long ples we solwota $\mathrm{i}$ finis long hem

wētētērē millipede kruked (bebet) Order Diplopoda

wēviak grasshopper grashopa

wëtëvut kind of small insect that makes hole in the gound wan kaen smol bebet we hem i mekem hol long graon

wōqōlmōo ${ }_{2}$ worm-like creature that has shape like yam called wōqōlmō wan kaen bebet we sep blong hem i olsem yam wōqōlmō

wōrō dragonfly dragonflae

wōsōr cicada wan kaen bebet we hem i singaot long naet

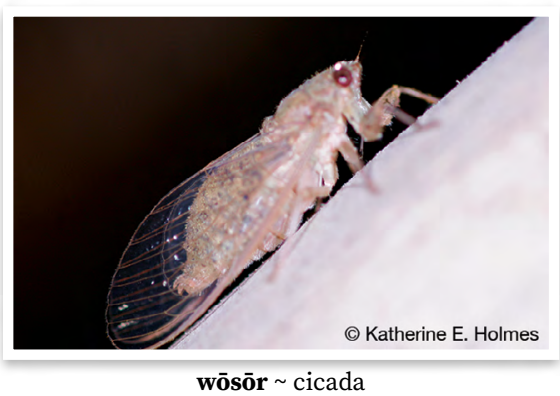

wökökö general name for caterpillars and other small wriggly creatures that don't have a specific name nem blong ol kaen smol samting olsem katapila 
wörumrum fruit fly wan kaen smolsmol bebet we fulap i stap raon long frut we i raep gud. Ol pijin (swiflet) i stap kakae

wötörör caterpillar katapila

wut louse laos wutbōn bedbug stingfli

wututan kind of insect like a cockroach but which lives in the ground and is small wan bebet we hem i olsem kakros be i smolsmol wan nomo we hem i stap long graon

\section{F Physical properties}

\section{Fo General}

garaq new $\sim$ niu
musu old $\sim$ olfala, wan samting (olsem
naef, haos) we hem i olfala

qar $\mathbf{1}$ - unripe $\sim$ no raep $2 \cdot$ raw, uncooked $\sim$ no dan $\mathbf{3} \cdot$ undried, untreated, as of green leaves, rather than dried or heat treated leaves no drae, no dan, olsem lif we i grin nomo, we ol i no putum long faea blong mekem i strong.

wōn 1 1 join, close up, seal together $\sim$ tufala saed i mit, olsem fasem lif, tufala saed i mit antap, kaliko i brok, joenem mo somap bakegen $\mathbf{2}$ - seal (hole in), join together, close up joenem, silim

wōnwōn ${ }_{1}$ whole, joined, complete fulwan

\section{F1 Appearance}

\section{F1.1 Visibility and colour}

añañ $1 \cdot$ yellow, be yellow yelo 2 • yellowness, yellow (one) yelowan

biliag $_{4}$ speckled, modifier derived from name for buff-banded rail, to indicate that the referent has speckled colouring dotdot, olsem kala blong nambilak

körkör 1 - black, be black blak 2 • blackness, black (one) blakwan $3 \cdot$ dark (colour) blak, tudak

mamē $\mathbf{1} \cdot$ red, be red $\sim$ red $\mathbf{2} \cdot$ redness, red (one) $\sim$ redwan mëlmël $1 \cdot$ shade, cool place sed, ples i kolkol 2 - become cool kam kolkol

qag $\mathbf{1} \cdot$ white $\sim$ waet $\mathbf{2} \cdot$ whiteness, white (one) $\sim$ waetwan $\mathbf{3} \cdot$ light (in colour), pale $\sim$ laet kala

qōlō $\mathbf{1} \cdot$ dirty, be dirty doti $\mathbf{2} \cdot$ become dirty, be dirty kam doti

qōn̄ov dull, be dull no braet

qöñöön purple $\sim$ popel

sēlsēl shine, emit light laet, saen

sil darkness, pitch black tudak

tōtōrōg $\mathbf{1} \cdot$ green, be green $\sim$ grin $\mathbf{2}$ • greenness, green (one) grinwan $\mathbf{3} \cdot$ blue, be blue $~$ blu $4 \cdot$ blueness, blue (one) bluwan

törö 1 1 make marking, draw, paint, dye $\sim$ kalarem, putum kala long wan samting $\mathbf{2} \cdot$ colour, markings $\sim$ kala

wamalak white with black splotches, referring to colour of pig or sometimes dog kala blong pig (o dog) we i waet mo blak smol

winiwin clean $\sim$ klin

won̄ light greyish, beige laet kala, olsem grei, laet braon

F1.2 Size, shape, weight, pattern

atik small, be small smol atiktik small smolsmol bëtutu big, large bigfala

bibis 1 - roll up, as pandanus, hair, mat $\sim$ rolemap wan longfala samting 


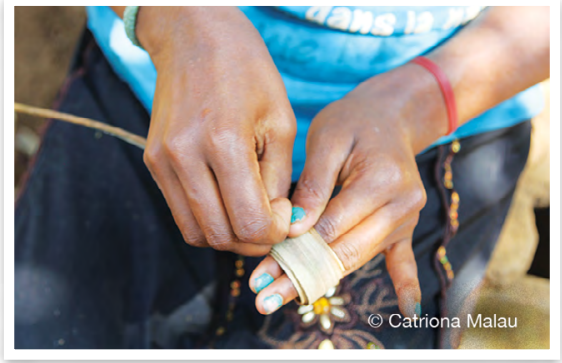

bibis roll up

2 roll (of something) rol (blong wan samting)

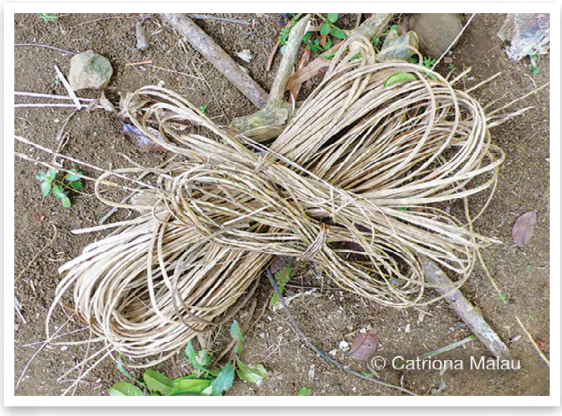

bibis roll

elel $1 \cdot$ high, high up, tall $\sim$ hae, antap $\mathbf{2} \cdot$ important $\sim$ impoten

elvet long, be long long, longfala

kēlēglēg crooked, bent, not straight kruked

$\mathbf{l a v}_{2}$ big big

luwō (fr.var. liwō) $\mathbf{1}$ - big, be big, sizable, become big, expand bigfala, kam bigwan $\mathbf{2}$ - important, high ranking hae, impoten

mav $1 \cdot$ heavy $\sim$ hevi, no laet

men̄meñ $1 \cdot$ light (weight), not heavy

laet, no hevi

mēvinvin thin tintin

mie long longfala

mötöltöl thick tik

nötu (fr.var. sönötu; sunötu) $\mathbf{1} \cdot$ small, be small, become small $\sim \operatorname{smol} 2$ • narrow, be narrow, become narrow $\sim$ smol, naro

qëtutu (fr.var. sëqëtutu) $\mathbf{1}$ - short, be short $\sim$ sotfala $2 \cdot$ be short, become short $\sim$ sotfala, kam sotwan rat flat place, area of land $\sim$ flat ples

sēsēvēl slanted, not flat no stret, no

lei flat

sial m̄ōtōtō level, even level

sursur down low $\sim$ daon

taqeqe flat $\sim$ flat

tenēnēg 1 - straight, not bent or curved stret, no kruked

tōw ${ }_{3}$ measure, mark out $\sim$ makem, mesarem

wōtōwtōw length of wood used to measure something out wud blong makem

waliög 1 - round, be round, spherical $\sim$ raon

wewete elongated, long and narrow longfala mo bunbun

\section{F2 Temperature, texture}

döw wet, be wet $\sim$ wetwet

gegen sharp (edge, as in knife) sap (long saed, olsem naef)

malas cold kolkol

mamas dry drae

mamēgin $1 \cdot$ be cold, cold $\sim$ kolkol 2 • cold $\sim$ kolkol

mere $\overline{\mathbf{n}}_{2}$ dry, dry up, dry out (wood, leaf, fruit, etc.), become withered (vegetation) drae (olsem wud o lif) metestes sharp (point, as in end of spear, knife) sap (poen, olsem en blong spia o naef)

mölumlum 1 • soft sofsof $2 \cdot$ slow, slowly slo, sloslo

qosmötöl blunt no sap

tutun $\mathbf{1} \cdot$ hot $\sim$ hot $\mathbf{2}$ ' have fever $\sim$ gat fiva

F3 Sounds - their types and qualities

aw shout, cry out singaot

dēn beat, tap lightly, bang, beating just to make a noise, rather than to make music or signal to people kilim (bambu, wud) blong mekem noes nomo 
qōrōtōt 1 - make a lot of noise, be noisy $\sim$ mekem tumas noes $\mathbf{2} \cdot$ loud sounds, too much noise $\sim$ tumas noes

rarö noise $\sim$ noes

tarōn be quiet, be calm, be peaceful stap kwaet

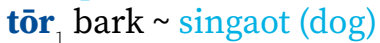

töqöl boom, bang, make a loud booming noise mekem bigfala noes olsem saon blong tanda

F4 Tastes and smells

bōn smell bad, as rotten food smel nogud

bunë smell smel

bōnan her/his/its smell smel blong hem

bunë qërët flying fox's smell smel blong flaengfokis

bunëk my smell smel blong mi

dēdērēs taste good swit

gagönus taste very good $\sim$ i swit we i swit gōgōn 1 • bitter konkon $\mathbf{2} \cdot$ salty, be salty konkon, sol $\mathbf{3} \bullet$ sour, be sour konkon $4 \cdot$ poisonous, be poisonous $\sim$ posen

lulum $1 \cdot$ have a good taste (of food) (kakae) i swit

lulumne taste (of something) tes blong wan samting

rōn̄ōbōn smell, passive sense of smell $\sim$ harem smel

sōbōn smell, sniff scent, active sensing of smell smelem

F5 Value

gōwē good gud

mav $2 \cdot$ difficult, hard, not easy $\sim$ had, no isi

men̄meñ $2 \cdot$ easy isi, no had

tisē bad $\sim$ nogud

turgi real, proper, true stret, barava, tru

wē $\mathbf{1} \cdot \operatorname{good}$, be good $\sim \operatorname{gud} \mathbf{2} \cdot$ be well, healthy stap gud, kam gud

\section{G Quantification}

\section{G1 Quantity}

bilēñ (fr.var. bilēn) $\mathbf{1} \cdot$ again, modifies verb in the verb complex $\sim$ bakegen 2 - as well, too, modifies noun in the noun phrase $\sim$ tu $3 \cdot$ more, other, another, modifier in the noun phrase $\sim$ moa, bakegen

döl all evriwan

garte 1 - leftovers, part remaining from something pat we i stap yet 2 - leftovers, food that someone has left uneaten $\sim$ hafkakae

gartan her/his/its leftovers hafkakae blong hem

garten nōtōn her child's leftovers hafkakae blong pikinini blong hem gartëk my leftovers hafkakae blong mi

gem (fr.var. gëm) $\mathbf{1}$ • just nomo $\mathbf{2}$ • only, just nomo

lōqtag plenty, many, be many plante, fulap

luw count (something) kaontem marö empty emti mōorag many, be many plante nivēs (fr.var. nives) $\mathbf{1} \cdot$ how many hamas $\mathbf{2}$ - few, several $\sim$ fiu, hamas nomo

sasarēt $\mathbf{1} \cdot$ enough $\sim$ inaf $\mathbf{2} \cdot$ same, equal semak, stret

taklē 1 - some, part of samfala, pat $2 \cdot$ part, partial $\sim$ haf, pat 
terē (fr.var. tere) plural marker, occuring before common nouns ol, olgeta

tōar (fr.var. tuar) other, another, the other, one of (a group) narawan

tutuqë many, plenty, be many fulap, plante

vaglōqtag $\mathbf{1} \cdot$ many times $\sim$ fulap taem $\mathbf{2}$ - do many times $\sim$ mekem fulap taem

vēvēg count (something) kaontem

vilēs all, all over evriwan

wōr $\mathbf{r}_{2}$ full, be full fulap

wuw $1 \cdot$ many, plenty, lots plante, fulap 2 - be many, plenty, become plentiful plante, fulap, kam plante

\section{G2 Numerals}

basbasne last laswan

bullevetē six together, group of six (of people) sikisfala (man)

bullōvōrō seven together, group of seven (of people) sevenfala (man)

bullövötöl eight together, group of eight (of people) eitfala (man)

bullövövet nine together, group of nine (of people) naenfala (man)

bulrō two together, group of two (of people) tufala (man)

bulsamul ten together, group of ten (of people) tenfala (man)

bultevelēm five together, group of five (of people) faefala (man)

bultöl three together, group of three (of people) trifala (man)

bulvet four together, group of four (of people) fofala (man)

levetē six siks

levetēne sixth, sixth one $\sim$ nambasikis

lōvōrō seven seven

lōvōrōne seventh, seventh one nambaseven

lövötöl eight eit

lövötölne eighth, eighth one nambaeit

lövövet nine naen lövövetne ninth, ninth one nambanaen

mölldöl hundred, reach, become a hundred $\sim$ handred, kasem handred möldöl vagōrō two hundred tu handred

möldöl vagtöl three hundred tri handred

-ne ordinal suffix ending long namba we i talemaot oda blong namba, olsem namba tu, namba tri, etc

ni- numeral marker maka we i go long fored blong ol namba

nirō (root rō) two tu

nitevelēm (root tevelēm) five $\sim$ faef

nitöl (root töl) three tri

nivet $(\text { root vet })_{3}$ ) four $\sim$ fo

qētqētne last laswan

rōne second, second one $~$ nambatu

sam̄ul ten ten

sam̄ul rō twenty twenti

samul tiwial dēmē nilevetē sixteen $\sim$ sikstin

samul tiwial dēmē nilövövet nineteen $\sim$ naentin

sam̄ul tiwial dēmē nilōvōrō seventeen $\sim$ seventin

sam̄ul tiwial dēmē nilövötöl eighteen eitin

sam̄ul tiwial dēmē nirō twelve twelf

sam̄ul tiwial dēmē nitevelēm fifteen $\sim$ fiftin

sam̄ul tiwial dēmē nitiwial eleven leven

sam̄ul tiwial dēmē nitöl thirteen totin

sam̄ul tiwial dēmē nivet fourteen fotin

samulne tenth, tenth one $\sim$ nambaten $\operatorname{tar}_{3}$ become, reach a thousand kasem taosen

tar vagōrō two thousand tu taosen tar vatiwial one thousand $\sim$ wan taosen

tevelēmne fifth nambafaef 
tölne third, third one nambatri vag- multiplicative prefix, added to numeral, indicates that the action is carried out specified number of times maka we i go long ol namba mo i talem se mekem hamas taem we namba i talemaot

vaglōvōrō 1 • seven times seven taem $\mathbf{2} \cdot$ do seven times $\sim$ mekem seven taem

vaglövötöl 1 • eight times eit taem $\mathbf{2} \cdot$ do eight times $\sim$ mekem eit taem vaglövövet $\mathbf{1} \cdot$ nine times $\sim$ naen taem $2 \cdot$ do nine times $\sim$ mekem naen taem

vagmöldöl 1 - hundred times handred taem $\mathbf{2} \cdot$ do a hundred times $\sim$ mekem handred taem

vagrō $\mathbf{1} \cdot$ twice $\sim$ tu taem $\mathbf{2} \cdot$ do twice $~$ mekem tu taem

vagrōne second time nambatu taem vagsamul $1 \cdot$ ten times $\sim$ ten taem $\mathbf{2} \cdot$ do ten times $\sim$ mekem ten taem vagtar $1 \cdot$ thousand times $\sim$ taosen taem $\mathbf{2} \cdot$ do thousand times $\sim$ mekem taosen taem

vagtevelēm 1 - five times $\sim$ faef taem 2 - do five times $\sim$ mekem faef taem vagtevelēmne fifth time $\sim$ nambafaef taem

vagtöl $\mathbf{1} \cdot$ three times $\sim$ tri taem $\mathbf{2} \cdot$ do three times $\sim$ mekem tri taem vagtölne third time $\sim$ nambatri taem vagvet $\mathbf{1}$ - four times $\sim$ fo taem $\mathbf{2}$ do four times $\sim$ mekem fo taem

vagvetne fourth time $\sim$ nambafo taem vagwuw $1 \cdot$ many times $\sim$ fulap taem $2 \cdot$ do many times $\sim$ mekem fulap taem

vetne fourth, fourth one $\sim$ nambafo wēvēs few fiu

\section{H Human classification}

\section{HO General}

masar poor person, who has no valuables, such as pigs and other valuable goods, money and land pua man we hem i nogat ol samting olsem pig mo narafala samting we $\mathrm{i}$ gat valiu blong hem

$\mathbf{0} \mathbf{l}_{1} \mathbf{2} \cdot$ call, give name to place or person $\sim$ singaotem (nem)

rege people, group of two or more people ol man, olgeta

sie name $\sim$ nem

sian her/his/its name $\sim$ nem blong hem

siëk my name nem blong mi

sul $_{2}$ people, general population, unified group of people pipol, ol man tan̄sar $\mathbf{1} \cdot$ person $\sim \operatorname{man} \mathbf{2} \cdot$ become a person, feel like you have become human again $~$ kam man

H1 Spirits and devils

dēbit good spirit (can be of dead or live person) who gives people good things gudfala speret, blong man we $i$ ded o laef yet, we i save givim gudfala samting long yu

Qet name of mythical creation figure, God God blong kastom

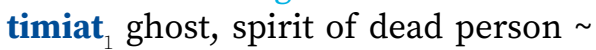
devel

tubu $2 \cdot$ ancestor $\sim$ bubu blong bifo tōbōn her/his ancestor bubu blong hem

tubuk my ancestor bubu blong mi 
vēlavēl ${ }_{2}$ person who knows how to poison people $\sim$ man we hem i save posenem man

vu magical spirit, a supernatural being that appears to people $\sim$ wan speret we i save kam helpem man

vusën̄sën̄ good spirit gudfala speret

\section{H2 Peoples and language groups}

tan̄sar $\mathbf{1} \cdot$ person $\sim \operatorname{man} 2 \cdot$ become a person, feel like you have become human again $~$ kam man

tan̄sar gaqag caucasian, white person $\sim$ waetman

tegvōnō local person man ples

wēsin̄asin̄ white person, nonindigenous person $\sim$ waetman

H3 People by age, development, life cycle

\section{H3.0 General}

masar poor person, who has no valuables, such as pigs and other valuable goods, money and land pua man we hem i nogat ol samting olsem pig mo narafala samting we i gat valiu blong hem

rege people, group of two or more people ol man, olgeta

sie name $\sim$ nem

sian her/his/its name $\sim$ nem blong hem

siëk my name nem blong mi

sul people, general population, unified group of people $\sim$ pipol, ol man

tan̄sar $\mathbf{1} \cdot$ person $\sim \operatorname{man} \mathbf{2} \cdot$ become a person, feel like you have become human again $~$ kam man

\section{H3.1 Male}

atm̄ēn $\mathbf{1} \cdot \operatorname{man} \sim \operatorname{man} \mathbf{2} \cdot$ male $\sim$ man biēn young unmarried male, in early stages of puberty, no facial growth as yet (younger than lomegev) yangfala boe, olsem se hem i nomo pikinini be i nogat mustas yet lōmegev $1 \cdot$ youth, young unmarried man $\sim$ yangfala $\mathbf{2}$ be youth, become youth $\sim$ kam yangfala

tamarge 1 old man olfala man $\mathbf{2}$ - old person $\sim$ olfala $\mathbf{3}$ grow old, become old $\sim$ kam olfala

\section{H3.2 Female}

dēm childless woman, woman who has never given birth woman we i neva karem pikinini

magte $_{2}$ old woman $\sim$ olfala woman

malmal $1 \cdot$ young unmarried woman, teenager $\sim$ yangfala gel $\mathbf{2}$ be young woman, become young woman kam yangfala gel

reqe $\mathbf{1} \cdot$ woman $\sim$ woman $\mathbf{2}$ - female woman

H4 Roles and status terms

bōg $\overline{\mathbf{o}}_{2}$ man who has not learned the traditional ways in the men's house to gain rank $\sim$ man we hem i no bin go long nakamal blong lanem stret rod blong kastom

maranag chief jif

meter woman of high rank who has studied to learn the true traditional way of life $\sim$ woman we hem i bin go long nakamal blong lanem stret rod blong kastom

m̄ëg carver, carpenter, handyman, man who has skill for making things $\sim$ man we hem i save katem wud, o gat skil blong mekem samting

mëg simsim carver who is very slow and careful about making good work $\sim$ man we hem i katem wud sloslo be hem i mekem gudwan

mëg sōbōr person who carves randomly with no skill $\sim$ man we $i$ katem wud olbaot nomo

mie 2 - first-born child, first thing, first one $\sim$ fasbon, fas samting $\mathbf{3} \cdot$ leader $\sim$ lida

qetegak captain, leader kapten, lida ronog rank rang 
sarsar woman who has not gained rank and learned the true traditional ways woman we hem i no bin go long nakamal

tövusm̄ēl chief who has gained rank in traditional way by kiling pig stret kastom jif we hem i bin kilim pig

vatōgō teacher $\sim$ tija

wöwut man of high rank who has studied the traditional rules and way of life in the men's house $\sim$ man we hem $\mathrm{i}$ bin go long nakamal blong lanem stret rod blong kastom

H5 Types of people not related to status/ profession

bulsal 1 - friend, mate, can be sexual partner or platonic friend $\sim$ fren $2 \cdot$ friend, used as an address term fren $\mathbf{3}$ - be friends, become friends $\sim$ fren $\mathbf{4}$ - become sexual partners fren (olsem gelfren mo boefren)

gōlōw orphan, child whose parents have died $\sim$ pikinini we $i$ nogat mama mo papa

mōdō unfortunate person, who people feel sorry for because they have no family, partner, or some other bad things are affecting their life $~$ man sori we laef blong hem i nogud tumas from i nogat famle, nogat man o woman blong hem, mo sam samting nogud long laef blong hem i mekem se ol man i sori long hem

nar 1 - widow, widower wido, woman we man blong hem i ded, man we woman blong hem i ded 2 - give up one specific favourite food for 1,000 days out of respect after a close relative has died $\sim$ taem mama o papa i ded, ol pikinini ol i mas givap wan kaen kakae we papa o mama $\mathrm{i}$ bin fidim olgeta wetem taem ol i smol. Ol i no save kakae kasem wan taosen dei. Tu ol i mas givim smol mane long hem we i ded mo hangem rop (blong burao) long nek blong hem blong givim saen se hem i lego wan kakae

tavalalē enemy badfren, enemi

varam twin $\sim$ twin

wömum quiet person $\sim$ man we i no stap toktok tumas

\section{H6 Address terms}

Bulsal 2 - Friend, used as an address term $\sim$ Fren

Bum Grandma, Grandpa, Grandson/ daughter; reciprocal address term used by grandparent to grandchild or grandchild to grandparent $\sim \mathrm{Bubu}$

Die Mum Mama

Diebum Grandma Bubu woman

Ika 1 - Wife, used as an address term $\sim$ Waef, olsem yu singaot long hem $\mathbf{2}$-address term, to someone who is close to you $\sim$ Dia

Mam 1 $\operatorname{Dad} \sim$ Papa 2 • God Papa God Mambum Grandad, Grandpa Bubu man

Qalēg reciprocal term used to address parents of spouse or spouse of child, father-in-law, mother-in-law, daughter-in-law, son-in-law palika

Rëwël brother-in-law; wife's brother, sister's husband (for man), reciprocal same generation in-law address term for men brata blong woman blong man, man blong sista blong man

Tatat (abbrev. Tat) Uncle, address term used towards uncle Angkel, nem we yu singaot long angkel

Tētē $\mathbf{2} \cdot$ My child, term of endearment used by parent to child $\sim$ Bebe, nem we mama o papa i yusum blong singaotem smol pikinini blong hem

Tutu address term used towards opposite sex sibling, brother (of a girl), sister (of a boy) brata blong wan gel o sista blong wan boe 
Vann̄ö niece, nephew, child of sister (of a man) smol angkel, pikinini blong sista (blong wan man)

Wimiar term of endearment used by parent-in-law to child-in-law nem we wan i yusum blong singaotem palika blong hem, we hem i woman blong boe blong hem o man blong gel blong hem
Wölus sister-in-law; husband's sister, brother's wife (for woman), reciprocal same generation in-law term for women sista blong man blong woman, woman blong brata blong woman

\section{Human qualities and emotions}

I1 Personality and moral evaluations

bioñ proud praod

bōgēt feel proud, act proudly, show off flas, mekem flas

bulbul $1 \cdot$ cooperation, togetherness, friendship $\sim$ kopereisen $\mathbf{2} \cdot$ cooperate $\sim$ kopereit

döm mav $\mathbf{1} \cdot$ respect $\sim$ ting hevi, respek $\mathbf{2} \cdot$ respect $\sim$ respek

lōlōqōr $\mathbf{1}$ - forgetful save fogetem tumas samting $\mathbf{2} \cdot$ heathen, lacking Christian enlightenment $\sim$ taem $\mathrm{O}$ man blong tudak

lōlwōn sad harem nogud, filing insaed long hat i no stret

meren $\overline{\mathbf{n}}_{1}$ lazy les

metwu personality, behaviour, manner, habit $\sim$ fasin metwōn her/his/its personality fasin blong hem

metwuk my personality fasin blong mi

mētigtisē selfish, not kind hearted selfis, fasin i nogud

mētigwē generous, kind hearted, well mannered gladhat, gudfala fasin

mōr lazy les

qaqa 1 - silly, ridiculous behaviour, ridiculous behaving person krangke, krangke fasin 2 - crazy person, behave in a ridiculous way $\sim$ mekem ol samting we i no stret olsem i hafmad; man we i krangke 3 - stupidly, not properly, randomly

olbaot, long kragke fasin

sen lie, tell untruth $\sim$ giaman

sōgsōg ${ }_{2}$ be generous $\sim$ gat gladhat

sötel proud, pride $\sim$ praod, wan blong mekem flas blong hem

survun greedy, putting oneself first before others, thinking highly of oneself $\sim$ kriti, putum yu wan mo daonem narawan

I2 Skill, ability, power

lōlōmeren $\mathbf{1}$ • wise, intelligent $\sim$ waes

2 -wisdom, knowledge $\sim$ waes, save tor $_{2}$ strong strong, taf

I3 Feelings and emotions

dasimreg hate, reject $\sim$ heitem, no wantem nating

en be angry, cross with $~$ kros long

göl speak angrily to (someone) tok kros (long)

liar $\mathbf{1} \cdot$ lost, be lost lus $\mathbf{2} \cdot$ confused, be confused $\sim$ konfius

lōlenen angry at $\sim$ kros long

lōlgagar very angry kros bigwan, kros tumas

lölö $\mathbf{1}$ ・ want $\sim$ wantem $\mathbf{2} \cdot$ like laekem 
malaklak $\mathbf{1} \cdot$ happy $\sim \operatorname{glad} \mathbf{2} \cdot$ happiness $\sim \operatorname{glad}$

mamakē be surprised at, about sapraes long

mamarseg (abbrev. marseg) 1 • pity, feel sorry (for) $\sim$ sori (long) $\mathbf{2}$ • unfortunate, pitiful sori

mēr $\mathbf{1} \cdot$ angry, be angry $\sim \operatorname{kros} \mathbf{2} \cdot$ anger $\sim$ kros

mëtëwtëw 1 - afraid, frightened fraet $\mathbf{2}$ - afraid of, frightened of $\sim$ fraet long mörös $\mathbf{1} \cdot$ want, need $\sim$ wantem $\mathbf{2} \cdot$ like

$\sim$ laekem $\mathbf{3} \cdot$ desire $\sim$ nid

malrōw be surprised $\sim$ sapraes

mataklav very happy glad tumas

qeneg 1 - afraid, frightened $\sim$ fraet

2 - fear, be afraid of $\sim$ fraet long

tēbēg express love for fasin blong soemaot lav long

tiam ${ }_{1}$ love lavem

timtiam love $\sim$ laf

\section{J Body parts and products}

\section{Jo General}

bakasē abdomen, under side of crabs and other crustaceans $\sim$ andanit, bel blong krab o naora

balsiē chin, jaw jin, jo

balsian her/his/its chin, jaw jin, jo blong hem

balsiēk my chin, jaw jin, jo blong mi

bēni $\mathbf{1} \cdot$ hand, arm han $2 \cdot$ wing of bird wing blong pijin

banēn gala her/his/its left hand lef han blong hem

banēn mōtō her/his/its right hand raet han blong hem

banēn her/his/its hand han blong hem

bēnik my hand han blong mi

bibiē neck nek

bibian her/his/its neck nek blong hem

bibiēk my neck nek blong mi

burus mete eyelashes, eyebrows hea blong ae

bus lav thumb nambawan fingga bus titivōnō index finger, pointer finger nambatu fingga long han

bustuwur pinky, baby finger las fingga long han busu 1 - digit, finger, toe $\sim$ fingga 2 • claw fingga blong pijin, fingga blong krab, naora

bōsōn her/his/its finger, toe fingga blong hem

busu ōr prawn or lobster claw fingga blong naora

busuk my finger, toe fingga blong mi

butö navel nambuton

buton her/his/its navel nambuton blong hem

butök my navel nambuton blong mi

diri leg, foot $\sim$ leg

dērēn her/his/its leg leg blong hem dirik my leg leg blong mi

gaböu wing wing

gabōōn its wing wing blong hem gaböuk my wing wing blong mi gaböu tō chicken wing jikinwing, wing blong faol

gagö butö umbilical cord rop we i joenem nambuton i go long mama gala left lefsaed

gargarke type of fatty looking substance, part of animal samting olsem gris we $i$ stap wetem mit blong animol 
garmiē tongue $\sim$ tang garmian her/his/its tongue tang blong hem

garmiēk my tongue $\sim$ tang blong $\mathrm{mi}$ gavivne armpit andanit blong han gavivnan her/his/its armpit andanit han blong hem gavivnëk my armpit andanit han blong mi

gölö tail tel golon her/his/its tail tel blong hem gölök my tail tel blong mi

kulë $\mathbf{1}$ • back (body part) baksaed $\mathbf{2}$ • behind, at the back, after (place or event) bihaen, afta

kōlan her/his/its back baksaed blong hem

kulëk my back baksaed blong mi lele rib(s) reb

lalan his/her/its rib(s) reb blong hem

lëlëk my rib(s) reb blong mi

lēnötō rooster's comb red samting we $i$ stap antap long hed blong man faol

lösö genitals, covers full genitals for male or female $\sim$ praevet pat blong hem

loson her/his genitals praevet pat blong hem

lösök my genitals praevet pat blong mi

luwö $\mathbf{1} \cdot$ tooth $\sim$ tut $\mathbf{2} \cdot$ tusk $\sim$ tut (blong pig)

luwö bas toothless person, person who has lost all or most of their teeth $\sim$ man we i nogat tut

luwö qō pig's tusk tut blong pig

luwon her/his/its tooth, teeth $\sim$ tut blong hem

luwök my tooth, teeth tut blong mi malawsöm middle finger medel fingga

malke sole (of foot), footstep andanit fut, futstep

malkan her/his/its sole andanit leg blong hem malkëk my sole andanit leg blong mi

marak fat (of animal) gris (blong animol)

mete eye $\sim$ ae

matan his/her/its eye $\sim$ ae blong hem

mëtëk my eye ae blong mi

mō long feather of a rooster's tail longfala feta long tel blong man faol

mōtō ${ }_{2}$ right $\sim$ raetsaed

mödu nose $~$ nus

mōdōn her/his/its nose nus blong hem

möduk my nose nus blong mi

mēèmèri tentacle, arm of octopus han blong nawita

nögö 1 • face fes

nogon her/his/its face $\sim$ fes blong

hem

nögök my face fes blong mi

nere 1 • lips $\sim$ lip, skin blong maot 2 • beak maot blong pijin

naran her/his/its lips, beak skin blong maot blong hem

n̄ërëk my lips skin blong maot blong mi

n̄usu $1 \cdot$ lips, snout (of animal such as pig) lip, skin blong maot $\mathbf{2} \cdot$ beak maot blong pijin

n̄ōsōn her/his/its lips, beak skin blong maot blong hem

nusuk my lips skin blong maot blong mi

qere ${ }_{2}$ penis $\sim \mathrm{kok}$

qaran his/its penis kok blong hem qërëk my penis kok blong mi

qörö ${ }_{1}$ ear sora

qoron her/his/its ear sora blong hem

qörök my ear sora blong mi

qösö groin, area of body around genitals pat blong bodi raon long ol tabu pat

qoson her/his groin tabu eria blong hem

qösök my groin tabu eria blong mi 
qötu $1 \cdot$ head hed

qōtōn her/his/its head hed blong hem

qötuk my head hed blong mi

qötubanēn her/his/its shoulder solda blong hem

qöu knee ni

qōōn her/his/its knee(s) ni blong hem

qöuk my knee ni blong mi

siri $1 \cdot$ bone $\sim$ bun

sērēn her/his/its bone(s) bun

blong hem

sirik my bone(s) bun blong mi

siri wawalag shin bone $\sim$ bun blong leg daon

sö $\mathbf{1} \cdot$ join joenem $\mathbf{2} \cdot$ joint, as in joint where two bones meet, joint in crafted wooden item joen, olsem joen blong tufala bun o joen long wud

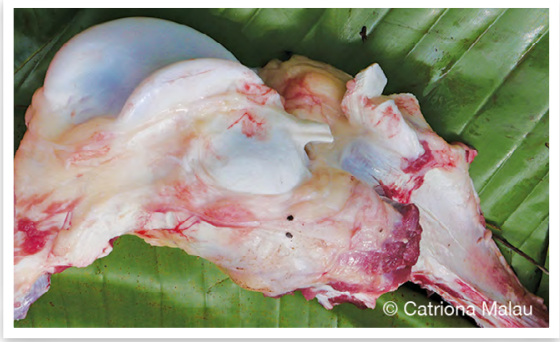

sö $\sim$ joint

sömodian̄ ring finger namba fo fingga long han

sus $_{4} \mathbf{1} \cdot$ breast $\sim$ titi

sōsōn her breasts titi blong hem

susuk my breasts titi blong mi

tarbiē body bodi

tarbian her/his/its body bodi blong hem

tarbiēk my body bodi blong mi

teqe belly bel

taqan her/his/its belly bel blong hem

tëqëk my belly bel blong mi

teqeliaw calf (of leg) mit we i stap bihaen long leg daon teqelsan back of head and back of neck bihaen hed, bitwin solda, stat antap long hed

turgēn $\mathbf{1} \cdot$ body bodi

tutgö fin wing blong fis

vele mouth $\sim$ maot valan her/his/its mouth maot blong hem

vërëk my mouth maot blong mi

vere $_{2} \mathbf{1} \cdot$ chest (of body) $\sim$ jes $\mathbf{2} \cdot$ liver $\sim$ leva

varan $1 \cdot$ her/his/its chest $\sim$ jes blong hem $\mathbf{2} \bullet$ her/his/its liver $\sim$ leva blong hem;

vërëk $\mathbf{1} \cdot$ my chest jes blong mi $\mathbf{2} \cdot$ my liver $\sim$ leva blong mi

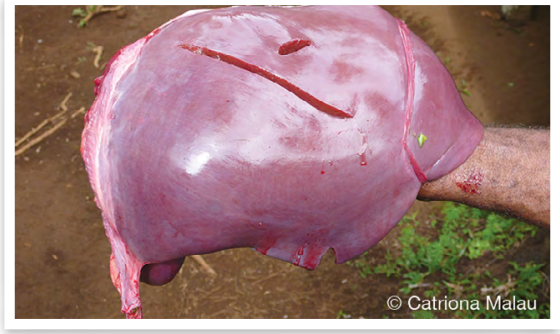

vere liver

vēsēn her/its vagina kan blong hem vikian her/his/its thigh top blong leg blong hem

vinti (fr.var. vēnti) $\mathbf{1}$ • skin skin vēntēn her/his/its skin skin blong hem

vintik my skin skin blong mi

vötu wōqōlqōl neck bone bun blong nek

vötubanēn her/his/its arm han (am) blong hem

vul 1 - hair hea $2 \cdot$ feather $\sim$ feta vōlōn her/his/its hair hea blong hem

vulu tō chicken feather feta blong faol

vuluk my hair hea blong mi

vusgö meat, flesh mit vusgon her/his/its meat $\sim$ mit blong hem 
wadalne cheek saed blong fes wadaln̄an her/his/its cheek saed blong fes blong hem

wadalnëk my cheek saed blong fes blong mi

walag, lower leg, between knee and ankle $\sim$ pat blong leg daon, bitwin ni mo angkol

wariē forehead $\sim$ fored

warian her/his/its forehead fored blong hem

wariēk my forehead fored blong mi

wawawne gill sora blong fis

wawleñ wing tip en blong wing

weles miar eyeball aebol, raon pat blong ae

wēlēgian $1 \cdot$ her/his/its heel bihaen blong leg blong hem $\mathbf{2}$ - hoof (of animal) bihaen long leg blong animol

wērē arse, buttocks as wērēk my arse as blong mi wirian her/his/its arse as blong hem

wëbëwbëwran her/his/its ankle hinsis blong fut blong hem

wobalaklak sucker, suction cup on octopus arm, tentacle samting long han blong nawita we yu save fas long hem

wotoqtoqolav stomach of cattle (cows only) bel blong buluk

wōqōlqōl back of neck bihaen long nek

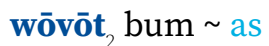

wölösömen testicles bol blong man o animol

wörurus tavav pancreas wan pat blong animol we i stap wetem gat

wöwöwut smaller stomach of cattle, omasum handred rum (blong buluk)

wulewēsēston̄ov operculum $\sim$ ae blong grinsnel
J1 Internal organs

gabala vein string blong blad gabala mōgōn her/his/its vein string blong blad blong hem

gëwtu stomach $\sim$ bel

giam 2 - net covering stomach $\sim$ net we i kavremap gat

mönug joint, where two parts of skeleton are joined together $\sim$ joen blong bodi

qultie intestine $~$ gat qultian her/his/its intestines, guts gat blong hem

tërtërgōr fascia, covering over meat waet samting we i stap bitwin long skin mo mit

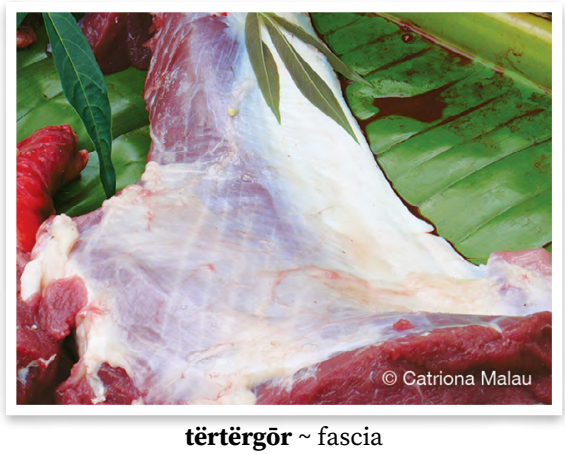

varwōs mōgōn her/his/its lungs lang blong hem

vere $\mathbf{1} \cdot$ chest (of body) jes $\mathbf{2} \cdot$ liver $\sim$ leva

varan $\mathbf{1} \cdot$ her/his/its chest $\sim$ jes blong hem $\mathbf{2} \bullet$ her/his/its liver $\sim$ leva blong hem;

vërëk $\mathbf{1}$ • my chest jes blong mi $\mathbf{2}$ • my liver $\sim$ leva blong mi

vötudōldōl oesophagus rod blong kakae

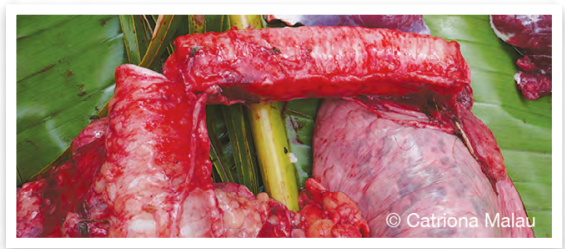

vötudōldōl oesophagus 
wēmiedaran (abbrev. miedar) her/his/ its heart hat blong hem

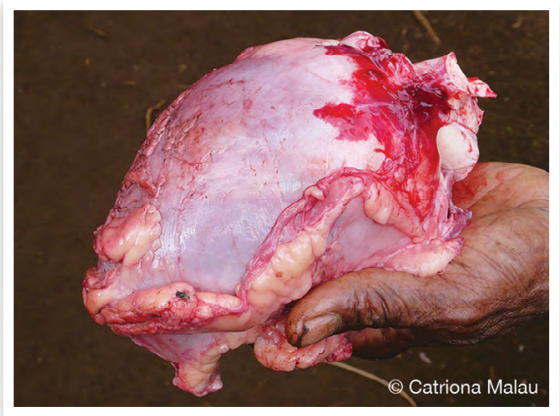

wēm̄iedaran $\sim$ heart

wēm̄ikm̄iak kidney kidni

wēvinn̄e xiphoid process, cartilaginous extension of lower sternum sofsof bun long ples we ol rib i joen, be daon

wōdōldōl trachea, windpipe pat blong bodi blong man mo animol we hem i paep blong pulum win long hem

wōs $\mathbf{s}_{2}$ lung lang, waetleva

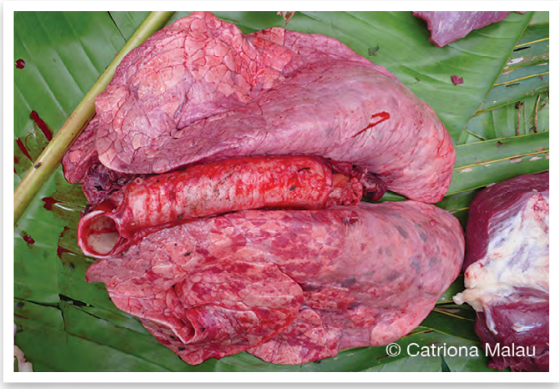

wōs lung

\section{J2 Body products}

dar $\mathbf{1} \cdot$ blood $\sim$ blad $\mathbf{2} \cdot$ bleed $\sim($ blad i) ron

daran her/his/its blood blad blong hem

dërëk my blood blad blong mi

dinsöw $1 \cdot$ saliva, dribble coming out of mouth, especially as with baby spet we i kamaot long maot (olsem blong bebe) dōn earwax $\sim$ doti blong sora

garmöös (fr.var. garmēs) $\mathbf{1} \cdot$ spit $\sim$ spet

$2 \cdot$ spit, spit on $\sim$ spet, spet long

kērēt ${ }_{2} \mathbf{1}$ - poo, excrement $\sim$ sitsit $\mathbf{2}$ • toilet $\sim$ toelet

lōt posset, baby milk vomit traot blong smol bebe

marak fat (of animal) gris (blong animol)

memesgēt sweat swet

menn̄ērēs dried mucus, snot wota blong nus we i drae

mim $1 \cdot$ urinate $\sim$ pispis $2 \cdot$ urine pispis

mimiē urine, wee pispis

mimian her/his/its urine $~$ pispis blong hem

mimiēk my urine pispis blong mi

nan $1 \cdot$ pus $\sim$ doti wota blong soa $o$ boela 2 - rheum, gound, mucus discharge from eyes during sleep or from conjunctivitis doti wota blong ae o blong sik red ae

nör snot wota blong nus

tan̄ēs tears wota blong ae

tia shit, excrement $\sim$ sitsit

tian her/his/its faeces $\sim$ sitsit blong hem

tie tō chicken faeces sitsit blong faol

tiēk my faeces sitsit blong mi

tie menek meconium; baby's first faeces which is almost black in colour $\sim$ fes sitsit blong bebe after hem ibon

tin̄is matan his/her tears wota blong ae blong hem

vul 1 • hair $\sim$ hea $2 \cdot$ feather $\sim$ feta vōlōn her/his/its hair hea blong hem

vuluk my hair hea blong mi

wese egg eg

wasan her egg eg blong hem

wësëk my egg eg blong mi

win̄i facial hair; beard, moustache mustas 


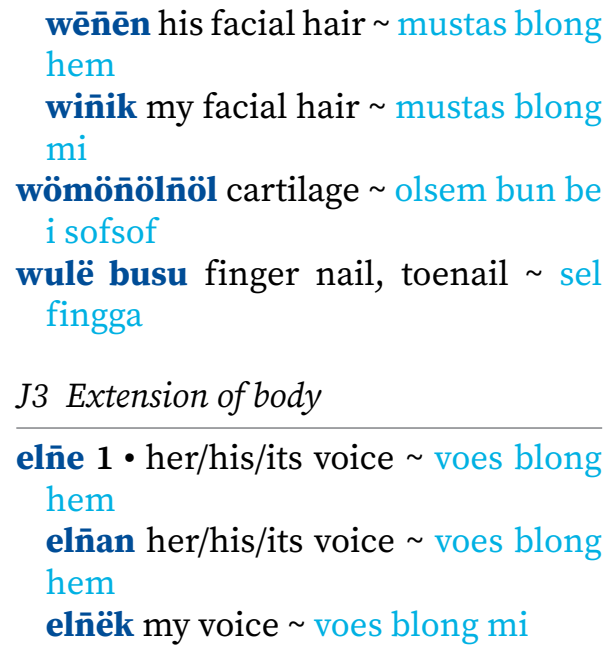

ete soul sol

atan her/his/its soul sol blong hem

ëtëk my soul sol blong mi

masgiē alone, by oneself $\sim$ hem wan masgian by himself, herself, itself hem wan

masgiēk by myself mi wan

qas be bald, bald person $\sim$ bolhed

tamtiē $1 \cdot$ shadow, reflection $\sim$ sado 2 - spirit, soul of a person $\sim$ speret blong wan man

tamtian her/his/its shadow, soul sado, speret blong hem

tamtiēk my shadow, soul sado, speret blong mi

wēbēlēt scar trak blong soa

\section{$K$ Body states and functions}

\section{K1 Physiological reactions}

bor laugh laf

borbor laughter $\sim$ laf

borseg laugh at $\sim$ laf long

burmat flutter eyelashes, make seductive looks to someone mekem ae, lukluk long wan man o woman we yu laekem hem

dar $\mathbf{1} \cdot \operatorname{blood} \sim \operatorname{blad} \mathbf{2} \cdot$ bleed $\sim($ blad i) ron

dim suck titi long

dōl swallow solem (daon)

dōlgia $\mathbf{1} \cdot$ choke $\sim$ no solem daon gud kakae o wota mo i fas long trot 2 • choke on jok long

garmös (fr.var. garmēs) $\mathbf{1} \cdot$ spit spet $\mathbf{2} \cdot$ spit, spit on $\sim$ spet, spet long

kir fart $\sim$ brekwin

kirkir have diarrhoea sitsit wota

$\mathbf{1} \overline{\mathbf{o}}_{3}$ vomit $\sim$ traot

lōlō vomit traot

lōlgagar very angry kros bigwan, kros tumas mamat $_{2} \mathbf{1} \cdot$ wake up $\sim$ wekap $\mathbf{2} \cdot$ open eyes, have one's eyes open $\sim$ openem ae, ae i open

memse breath $\sim$ win (blong hem) memsan her/his/its breath win blong hem

memse timiat spirit's breath $\sim$ win blong devel

memsëk my breath win blong mi

memseg $\mathbf{1}$ • breathe $\sim$ pulum win 2 • rest $\sim$ spel

memesgēt sweat swet

mim $\mathbf{1} \cdot$ urinate $\sim$ pispis $\mathbf{2} \cdot$ urine pispis

mösön hiccups hikap

mamēèv yawn yon, openem waed maot, olsem taem yu taed

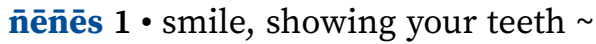
smael, soem tut blong yu 2 - show teeth $\sim$ soemaot tut

$\overline{\mathbf{n}} \mathbf{o} \bar{n} \mathbf{r}$ snore $\sim$ pulum win

sus $_{4} \mathbf{2} \cdot$ suckle, suck on $\sim$ titi, titi long

tarēñ sneeze $\sim$ snis

titiav shit, defecate $\sim$ sitsit 
tōv $\mathbf{1} \cdot$ cough $\sim$ kof $\mathbf{2} \cdot$ have a cold $\sim$ kof, kasem kof

vun $_{4}$ fart inaudibly $\sim$ man $i$ fat we i kwaet nomo

\section{K2 Body states}

\section{K2.1 Temporary}

gargarmamas fast, refrain from eating certain foods for a particular reason lego kakae mo dring

iamron tired $\sim$ taed

malala tingle, have pins and needles ded, filing long bodi taem yu sidaon long leg o han blong yu

mamēgin $1 \cdot$ be cold, cold kolkol $2 \cdot$ cold $\sim$ kolkol

mataq fresh wound, cut $\sim$ gat kil

mav 1 - heavy $~$ hevi, no laet 2 • difficult, hard, not easy $\sim$ had, no isi meneg 1 - hard, be hard strong, olsem i no sofsof $\mathbf{2}$ - be strong, powerful strong, olsem i gat paoa 3 - intense $\sim$ strong, olsem i gat paoa blong hem $\mathbf{4} \cdot$ be determined strong, olsem fasin i strong

mēlin̄sal be hungry, hunger hanggri mëmës hurt, be sore, ache soa

mëvtia wound gat kil

mörö thirst, be thirsty tosta

mörötröt weak, faint, as from hunger slak olbaot, nogat wan samting $i$ pulum tugeta paoa blong olgeta

möölöslös weak slak

nal tired, slack taed, slak

qaqa 1 - silly, ridiculous behaviour, ridiculous behaving person krangke, krangke fasin 2 - crazy person, behave in a ridiculous way mekem ol samting we i no stret olsem i hafmad; man we i krangke 3 - stupidly, not properly, randomly olbaot, long krangke fasin

qorogrog have tiny lumps, spots, as on baby's skin gat spot long bodi (blong bebe) rēg $1 \cdot$ swell, become swollen $\sim$ solap $\mathbf{2}$ - fat, be fat $\sim$ fatfat

sak swell $\sim$ solap

wamasal kind of unidentified lump on skin that becomes a sore $~$ kaen soa long skin

wawarēs lump on skin (unknown skin condition, like pimple but with no pus inside) spot long skin

wē $\mathbf{1} \cdot \operatorname{good}$, be good $\sim \operatorname{gud} \mathbf{2} \cdot$ be well, healthy stap gud, kam gud

wēqig swelling, lump on person or tree that swells but does not hurt ples long bodi o wud we i solap be i no soa

\section{K2.2 Permanent}

atm̄ēn $\mathbf{1} \cdot \operatorname{man} \sim \operatorname{man} \mathbf{2} \cdot$ male $\sim$ man

matwōn blind blaen

qōrwōn deaf person, be deaf $~$ sora $i$ fas

reqe $1 \cdot$ woman $\sim$ woman $2 \cdot$ female $\sim$ woman

wösuwun cripple, person who is unable to walk man we i no save wokbaot

K3 Sickness, death, disease, injury

bakō skin condition like ringworm where the skin becomes scaly and isn't strong, peeling off easily wan sik blong skin we i olsem ringwom mo skin i luk olsem skel blong fis mo i save kamkamaot

ēlgōr $1 \cdot$ look after, care for $\sim$ lukaotem $\mathbf{2}$ - watch out, be careful lukaot gerger scabies sik blong skras görgör kind of skin condition in which skin has lots of tiny, rough bumps, like sandpaper, but is not too itchy kaen sik blong skin we i gat ol smolsmol lam long hem, be i no skras tumas

kirkir have diarrhoea sitsit wota

lēs nit, louse egg eg blong laos 
lisia sickness, illness, disease sik, siknes

los sick, be sick sik

$\mathbf{1} \overline{\mathbf{o}}_{3}$ vomit $\sim$ traot

lōlō vomit traot

lōlmusugsug nausea, feeling that one is going to vomit sik olsem yu harem se bae yu traot

mañ serious cough, with wheezing, asthma kof nogud

mataq fresh wound, cut gat kil maw $_{1}$ heal (soa i) drae, kam gud

mete mōtō (fr.var. wemete mōtō) pimple spot long skin, espesli we i stap long fes blong ol yangfala, mo $i$ gat wota blong hem

mëvtia wound gat kil

mōnōg sore on body soa long bodi

qet mëmës headache, have headache

$\sim$ hed i soa

qēsis sore, similar to a boil, caused by a small scratch which then becomes infected, swells up and fills with pus $\sim$ kaen soa we hem i gat doti wota insaed olsem boela

qorogrog have tiny lumps, spots, as on baby's skin gat spot long bodi (blong bebe)

sislaqlaq chicken pox jikinpok

sosov skin condition caused by getting too wet and cold in rain, resulting in swollen, itchy, spotty skin skin i skras, i solap, i tik, from yu stap long taem tumas long ren mo kolkol

taqgilgil lie down motionless, with no energy, as when someone is very sick taem we siknes i kasem wan man mo hemi no save muv, i leidaon nomo

tenge leaf remedy, plant used for traditional medicine, fertilising crops, aiding fishing and other traditional remedies and purposes lif meresin o lif we ol i yusum long saed blong kastom olsem blong fis o long garen tōv $\mathbf{1} \cdot$ cough $\sim \operatorname{kof} \mathbf{2} \cdot$ have a cold $\sim$ kof, kasem kof

tutun $\mathbf{1} \cdot$ hot $\sim$ hot $\mathbf{2}$. have fever $\sim$ gat fiva

vaēs resuscitate $\sim$ mekem i laef

van̄ revive $\sim$ mekem i kam laef bakegen

vësëw treat illness by taking leaves of certain medicinal plants, steeping them in boiling water, then covering the person with the treatment so that they can breath in the steam $\sim$ tritim sik wetem lif meresin we yu kukum ol lif long wota, afta yu mekem man we i sik i smelem stim

vōn sore on scalp, caused by lice soa long hed we laos i mekem

vun $_{5}$ ringworm $\sim$ ringwom vun meren type of ringworm where the skin is dry with no liquid coming out unless it is scratched kaen ringwom we wota i no stap kamaot long skin oltaem

vun qar $1 \cdot$ type of ringworm where the liquid is coming out all the time kaen ringwom we wota blong hem i stap ron oltaem 2 - type of disease that affects trees and other plants, where liquid comes out of the affected part kaen sik blong wud we wota i stap kamaot long skin blong hem oltaem

wamasal kind of unidentified lump on skin that becomes a sore $\sim$ kaen soa long skin

wawarēs lump on skin (unknown skin condition, like pimple but with no pus inside) spot long skin

wos $_{2}$ boil, pus-filled swelling boela wos matëdër carbuncle, cluster of boils that are badly infected boela we i gat plante ae long wan ples

wösuwun cripple, person who is unable to walk man we i no save wokbaot 


\section{Stance and motion}

\section{L1 Stance, position}

\section{L1.0 Stance, position - general}

dèrē $\mathbf{1} \bullet$ wait for $\sim$ wet long $\mathbf{2}$ • wait wet

diam hang hang

dimdiam hammock, something one can hang in $\sim$ hamak

diar $\mathbf{1} \cdot$ wait for $\sim$ wet long $\mathbf{2} \bullet$ wait wet

kat stick to fas long

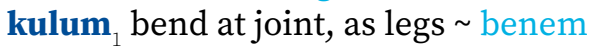
memseg $2 \cdot$ rest $\sim$ spel

rivteg $1 \cdot$ near, close by $\sim$ klosap 2 • near to, close to klosap long

tenēnēg 1 - straight, not bent or curved stret, no kruked

tog $1 \cdot$ stay, be in a place, remain in a place or way, live in a place $\sim$ stap turm̄̄o go first, be in front, lead stanap fastaem, go fastaem, lidim

L1.1 Stance, position - vertical axis

gēgēt be on balls of feet or tippy toes, not full, flat feet $~$ stanap long en $\mathrm{o}$ fingga blong leg

$\operatorname{siag}_{1}$ sit, sit down $\sim$ sidaon

siag gēgēt ${ }_{1}$ squat sidaon, olsem yu bendem leg mo as blong yu i no tajem graon

taq sit, be in sitting position $\sim$ sidaon tur 1 - stand, stand up standap 2 • have a stance, maintain a position on a particular thinking or argument stanap long wan tingting

\section{L1.2 Stance, position - horizontal axis}

atelen face upwards, for items that have division into top side and underside, such as person lying, bowl, plate, cup fes o luk i go antap, olsem man i leidaon, kap o plet

bētul lie down $~$ leidaon

ōn lie, lie down leidaon ōnveg lie beside, lie next to leidaon klosap long

vateqev face downwards, for items that have division into top side and underside, such as person lying, bowl, plate, cup fes o luk i go daon, olsem man i leidaon, kap o plet

\section{L2 Movement}

\section{L2.0 Movement-general}

dēn̄ $\mathbf{1} \bullet$ arrive $\sim$ kasem $\mathbf{2} \bullet$ reach, arrive at $\sim$ kasem

gav fly flae

gōl ${ }_{2}$ shake, shudder $\sim$ seksek

$\mathbf{k a l}_{2} \mathbf{1} \cdot$ go up, motion or event directed upwards go antap $\mathbf{2} \cdot$ go landward, ashore, inland go antap long so, long bus $3 \cdot$ go upstream $\sim$ go antap (folem wota) $\mathbf{4}$ - travel in a southeasterly direction (of travel beyond island to other islands) $\sim$ go long saot long narafala aelan $\mathbf{5} \cdot$ go inside, enter $\sim$ go insaed

kēl $\mathbf{1}$ - return kambak 2 - face towards, be directed towards $\sim$ fes $\mathrm{i}$ go long

kuëg shake, move, push on swing sekem, muvum, pusum

lak dance $\sim$ danis

le ris turn, turn over $\sim$ tanem

lil run, move very quickly resis, ron kwiktaem tumas

malaglag wobbly, be wobbly muvmuv

mōōōlgōl wobbly, be wobbly muvmuv

qēt 1 - finish, be finished, end, cease $\sim$ finis 2 - finish, complete, stop, cease $\sim$ finisim

rerev $_{2}$ slither, creep, movement low to the ground and generally as something that does not have legs 
kalkal, wokbaot, muv olsem wan samting we i nogat leg, olsem snek, snel, nawita, slug

sial float $\sim$ flot

sialtislan̄ slip glis

siōl go ashore kamso

sō paddle $\sim$ parelem

tatag $\mathbf{1}$ - follow $\sim$ folem $\mathbf{2} \cdot$ do according to, in accordance with $\sim$ mekem folem

tetel walk around, go somewhere just for enjoyment, with no particular purpose $\sim$ wokbaot, wokbaot blong enjoem nomo

$\mathbf{t} \overline{\mathbf{o}}_{2}$ run away $\sim$ ronwe

ukuëg $\mathbf{1}$ • depart, leave go, lego 2 • leave (place, person) lego

$\operatorname{van}_{1} 1 \cdot$ go (unmarked for direction) go

van me $\mathbf{1} \cdot$ come $\sim \operatorname{kam} 2 \cdot$ become $~$ kam

$\operatorname{var}_{1} \mathbf{1} \cdot$ stomp, tread heavily on prumbut $\mathbf{2} \cdot$ go in upwards direction $\sim$ go antap $\mathbf{3} \cdot$ stand on, kick something with stanap long, kik samting wetem

verdēn̄ meet, join $\sim$ mit

vērēg $\mathbf{1} \cdot$ run $\sim$ ron $\mathbf{2}$ - flow (of water, liquid, etc.) (wota i) ron 3 - run (tap), cause to flow $\sim$ mekem i ron wērēreg fly flae

\section{L2.1 Movement-vertical axis}

el dive down $\sim$ daeva i go daon, stap antap long sefes mo go daon

$\mathbf{k a l}_{2} \mathbf{1} \cdot$ go up, motion or event directed upwards go antap $\mathbf{2} \cdot$ go landward, ashore, inland go antap long so, long bus $3 \cdot$ go upstream $~$ go antap (folem wota) $\mathbf{4} \cdot$ travel in a southeasterly direction (of travel beyond island to other islands) $\sim$ go long saot long narafala aelan $\mathbf{5} \cdot$ go inside, enter go insaed

mës fall foldaon

rem climb klaem rōr ${ }_{2}$ go deep inside, either down or lengthwise, fall into hole, sink into something go dip insaed long wan samting, i go daon o go longwe, draon insaed long hol

rōw jump jam

sōw $3 \cdot$ go down $\sim$ go daon

tēqēl 1 - go down, motion or event directed downwards $\sim$ go daon 2 • go seaward, go further out to sea go long solwota $\mathbf{3} \cdot$ go downstream $\sim$ go daon (folem wota) 4 • travel in a northwesterly direction (of travel beyond island to other islands) $\sim$ go long not long narafala aelan

tōrak stand up, get up stanap, girap tul $1 \cdot$ drown, fall down from height $\sim$ draon $\mathbf{2}$ - submerge $\sim$ draonem $\mathbf{3}$ • set (of sun) $\sim$ go daon, draon (san) tul viteg draonem $i$ go

\section{L2.2 Movement - horizontal axis}

gër $\mathbf{1} \cdot$ swim $\sim \operatorname{swim~} \mathbf{2}$ - wade through water $\sim$ wokbaot krosem wota

kalkal (fr.var. kakal) crawl wokbaot fo leg

rēv pull pulum

waliög $1 \cdot$ round, be round, spherical raon $\mathbf{2} \cdot$ go around something, cover all areas $\sim$ raonem wan samting, no mata wanem sep

L3 Open and close

\section{L3.1 Open}

dur $1 \cdot$ stab, poke hole in something $\sim$ stikim $2 \cdot \operatorname{dig}$ hole $\sim$ digim hol 3 - hollow out inside of canoe digimaot insaed blong kenu

lie hole $\sim$ hol

mamat $_{2} \mathbf{2}$ - open eyes, have one's eyes open $\sim$ openem ae, ae i open

mëw open and close i open, i klos

mamaē clear, be open, not enclosed (of area) klia, open ples

marö empty emti

$\overline{\mathbf{m}} \mathbf{o} \mathbf{l} \overline{\mathrm{o}}$ form hole, have hole, cavity brok, gat hol 
qarañ hole $\sim$ hol

qarörö hole hol

qètēg $\mathbf{1}$ - start stat, statem $\mathbf{2}$ • inceptive, first verb in serial verb construction, indicating the inception of the action of the verb that follows $\sim$ statem

viër open out flat openem i kam flat vulëg open (eye) openem (ae)

wawañ open mouth openem maot

wiak 1 • open openem 2 - open, be open $\sim$ open

\section{L3.2 Close}

bur $_{2} \mathbf{1} \cdot$ close, shut $\sim$ sarem 2 - be closed $\sim$ klos

tövun (fr.var. tuvun) $\mathbf{1}$ • bury berem $\mathbf{2} \cdot$ fill in (hole), cover over something in hole $\sim$ berem

wōn 1 - join, close up, seal together $\sim$ tufala saed i mit, olsem fasem lif, tufala saed i mit antap, kaliko i brok, joenem mo somap bakegen $\mathbf{2}$ - seal (hole in), join together, close up joenem, silim

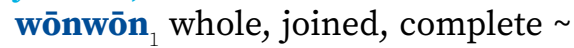
fulwan

wōn blocked, be blocked fas

wōr ${ }_{2}$ full, be full fulap

\section{L4 Exist}

$\mathbf{a} \overline{\mathbf{e}}_{1}$ have, existential predicate marker $\sim$ i gat

dun $1 \cdot$ true, be true, real $\sim$ tru $2 \cdot$ sure, tell truth $\sim$ sua, tru $\mathbf{3} \bullet$ truth $\sim$ tru

ès $\mathbf{1} \cdot$ alive, be alive $\sim$ laef $\mathbf{2} \cdot$ life $\sim$ laef (blong)

timiak 1 - like, marks manner or similative role $\sim$ olsem $2 \cdot$ be like $\sim$ olsem

\section{L5 Do}

da $1 \cdot$ make, do mekem $2 \cdot$ cause; occurs as initial verb in causative serial verb construction $\sim$ mekem 3 - do something mean or bad to someone; mistreat, tease, hassle mekem daēl try traem

gis build (house) bildim (haos)

qētēg $\mathbf{1}$ - start $\sim$ stat, statem $\mathbf{2}$ • inceptive, first verb in serial verb construction, indicating the inception of the action of the verb that follows $\sim$ statem

taōrmat $1 \cdot$ be ready, be prepared redi $2 \cdot$ prepare, make something ready $\sim$ mekem redi

da taōrmat prepare $\sim$ mekem redi

wiwieg $1 \bullet$ work $\sim$ wok $2 \bullet$ work $\sim$ wok

\section{L6 Change of state}

lies $1 \cdot$ change, exhange, replace one thing with another $\sim$ jenisim $\mathbf{2} \cdot$ take someone's place, do something in place of another tekem ples blong narafala man

lilies change (clothes) jenis, jenisim klos

meren̄ dry, dry up, dry out (wood, leaf, fruit, etc.), become withered (vegetation) drae (olsem wud o lif) qar $\mathbf{1}$ - unripe $~$ no raep 2 - raw, uncooked $\sim$ no dan $\mathbf{3} \cdot$ undried, untreated, as of green leaves, rather than dried or heat treated leaves no drae, no dan, olsem lif we i grin nomo, we ol i no putum long faea blong mekem i strong.

qètēg $\mathbf{1}$ - start stat, statem $\mathbf{2}$ • inceptive, first verb in serial verb construction, indicating the inception of the action of the verb that follows $\sim$ statem

$\mathbf{r a n}_{1}$ dry (yam, wild yam, taro, etc.) drae (olsem yam, wael yam, taro)

ris $\mathbf{1} \cdot$ turn $\sim$ tanem $2 \cdot$ change into tanem i kam

ti 1 1 start $\sim$ statem $\mathbf{2} \bullet$ light $\sim$ laetem

tōw $\mathbf{w}_{2}$ grow $\sim$ gro

van me $\mathbf{1} \cdot$ come $\sim \operatorname{kam~} 2 \cdot$ become $~$ kam

wör place in sunny position to dry putum long ples (olsem long san) blong mekem se i drae 


\section{Artefacts, material culture and manufactured things}

M1 Tools, weapons, belongings

balbal $\mathbf{1} \cdot$ scissors $\sim$ sisis $2 \cdot$ cut (with scissors) $\sim$ katem (wetem sisis)

barbar $_{2}$ axe akis

bele handle, hard handle as of knife, cup, kettle handel, olsem blong naef, kap, ketel

bur light laet

busmaraw nail, wooden stake $\sim$ nil

dinir strainer for kava sev blong kava

döwurwur broom brum

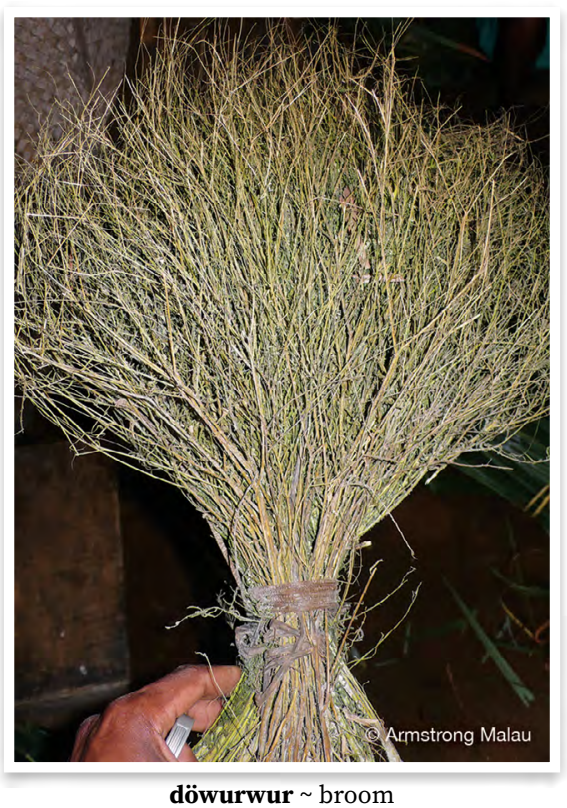

ga $_{1} \mathbf{2}$ - rope, string, other rope-like items used for tying rop

gabal long wooden tongs used for picking up hot stones or charcoal from stone oven wud blong karemaot ston long oven

gakōkō swing made from rope swing galēm long wooden pole used for evenly spreading charcoal and heat of stones in stone oven $\sim$ wud blong miksimap jakol mo ston long oven

gasel knife $\sim$ naef

gasel luwō machete, large knife, used mostly for garden work and chopping wood busnaef, big naef gasel nötu small knife, kitchen knife used mainly for cooking, simple daily use $\sim$ smolnaef

gasim length of bamboo used for removing breadfruit from the tree bambu we ol i yusum blong karemaot bredfrut long stamba

gatitieg bird or pig trap made from rope $\sim$ trap blong pijin o pig

giam $1 \cdot$ net $\sim$ net

giam vus net with a handle $\sim$ kaen net wetem handel blong hem

gil 2 - digging stick $\sim$ stik blong digim graon 3 - stick used for removing husk from coconut wud blong karemaot skin long kokonas

kar spear with four prongs and rubber spia we hem i gat raba blong hem mataqē stone or clamshell axe $\sim$ ston akis o akis wetem sel blong natalae metekerker comb kom

qesekēr club, length of wood used as weapon $\sim$ nalnal

qōrser kind of spear with several prongs on the end $\sim$ wan kaen spia we $\mathrm{i}$ gat plante poen long en blong hem

ririn̄i belongings, possessions, things $\sim$ ting (blong wan man)

wēririn̄i materials needed for making a particular item, such as house, canoe, basket ol samting we yu nidim blong mekem wan samting ser $_{1}$ spear spia 
tabē carved wooden platter, used for pounding nalot and making kava natambia, wuden plet

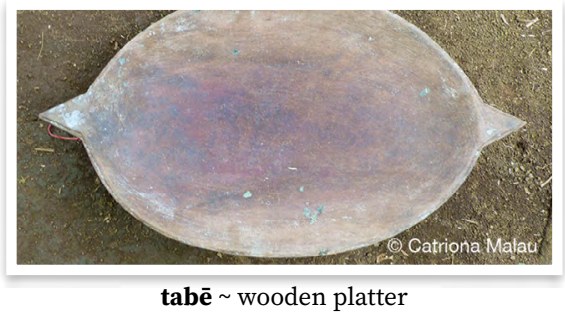

tele axe $\sim$ akis

tēqès tool for cutting wood to make it flat tul blong katem wud i flat

timiatèq gun masket

tutugon walking stick wokingstik

via grater for grating nuts and tubers

to make laplap and nalot samting

blong salem nangae o ol kakae

via qatē grater made from stem of tree fern samting blong salem laplap, nat o samting olsem we ol i mekem long blakpam

via tin grater made from old tin that has holes punched into it samting blong salem laplap, nat o samting olsem we ol i mekem long tin

vidëm adze, tool for hollowing out canoe aj, tul blong katem kenu vus bow $~_{1}$ bonaro

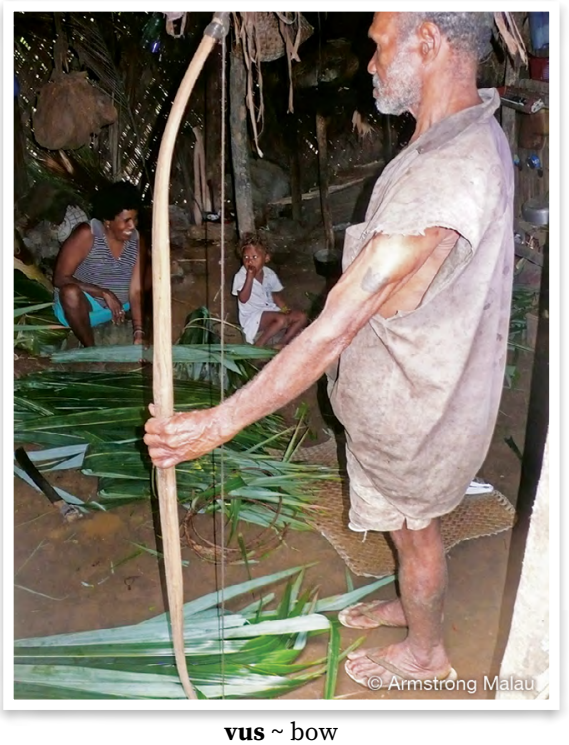

walaqlaq gōsōw rat trap trap blong rat

wetele iron aean

wetele lan̄lan̄ metal rods used as support for saucepan when cooking over fire aean blong ples blong kuk

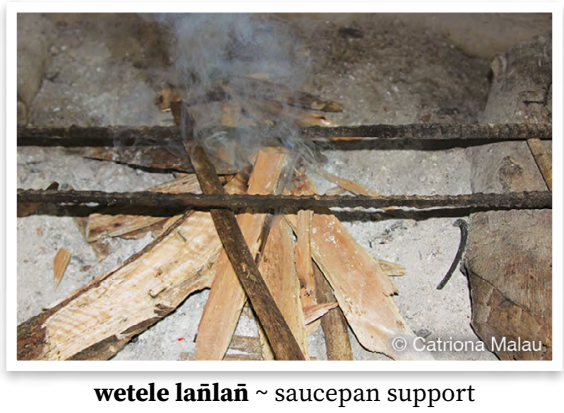

wèt carrying stick, length of wood used for carrying items over shoulder or between two people wud blong karem samting long hem wētēq kind of arrow which has a blunt end so that it will bounce off a tree if the target is missed and not get stuck, used for shooting birds wan kaen aro we en blong hem i no sap blong hem i no save fas long wud taem yu sut wetem, i mas foldaon, ol i yusum blong sutum pijin

wow ${ }_{1}$ kind of fish trap used in the deep sea, which is like a lobster pot but used only for catching fish wan kaen net trap we yu yusum long medel si. Yu putum bet insaed mo i gat wan hol antap be taem ol fis ol i go insaed ol i no save kamaot bakegen

tul wōw throw wōw fish trap into the sea draonem wōw net long solwota wötöv bottle botel

wöwöwör qèsaqēs kind of trap used close to the shore for catching small fish and particularly lobster kaen trap we yu yusum klosap long so blong kasem ol smol fis mo speseli naora 


\section{M2 Built environment}

M2.0 General

$\mathbf{a r}_{2}$ fenced in area, pen, compound, enclosure $\sim$ fenis

doot 2 - sago palm thatch $\sim$ lif natanggura, taj

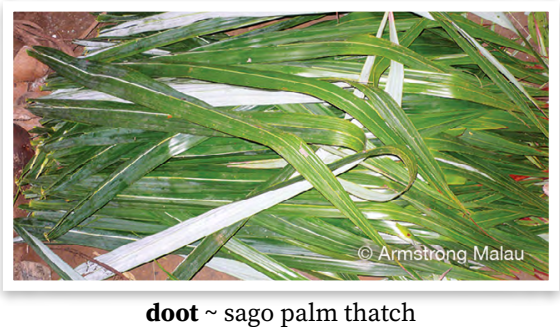

gis ${ }_{2}$ build (house) bildim (haos)

gövur house, generic name for building haos

gövur gōrōn̄ church jos

gövur lisia hospital, clinic klinik

gövur tatar church jos

kulë gövur back, sides and roof of house, sections of house behind the front $~$ baksaed blong haos, we $\mathrm{i}$ kavremap saed mo ruf

nögö gövur front of house fored blong haos

qötu gövur roof beam of house top blong haos

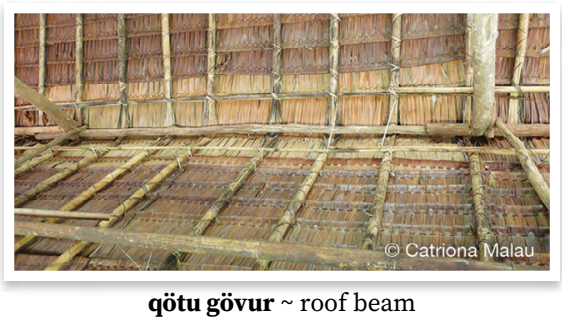

nötu gövur toilet, out house smolhaos

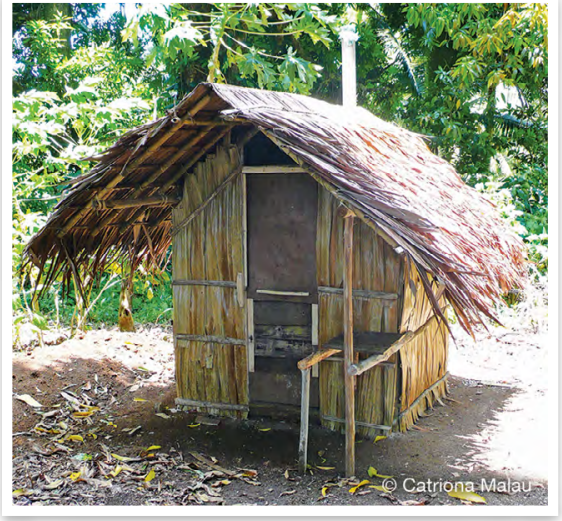

nötu gövur toilet house

tes $_{3}$ toilet $\sim$ toelet

vōnō $2 \cdot$ village $\sim$ vilej

nögö vōnō whole village, look or appearance of village $\sim$ eria blong vilej

\section{M2.1 Parts of a building}

at tie thatch slabs onto bamboo rafters

$\sim$ fasem lif natanggura $i$ go antap long bambu

at rēv tie sago roof thatching loosely, not close together $\sim$ fasem lif natanggura we i no fasfas tumas at tit tie sago roof thatching with lots of leaves close together $\sim$ fasem lif natanggura we i fasfas gud wetem plante lif klosap

babēris $1 \cdot$ wall of house $\sim$ wol blong haos $\mathbf{2} \cdot$ weave wall of house $\sim$ wivim wol blong haos

bēmtawal piece of sago palm thatch which covers over the top of the roof natanggura we ol i somap blong blokem top blong haos

bēr tie bamboo rafters to beam of roof before tying thatch onto rafters $\sim$ fasem bambu long ol wud (bifo somap taj i go long hem)

butun 1 - front wall of house $\sim$ fron wol blong haos $\mathbf{2} \cdot$ make front wall of house $\sim$ wivim fran blong haos 
butū lav front walling of house made by tying together large upright lengths of bamboo woling long fored blong haos we ol i fasem tugeta ol bigfala bambu

butun̄ rēg front walling of house made by tying together small upright lengths of bamboo woling long fored blong haos we ol i fasem tugela ol smolsmol bambu

gas make roof of house by making two lengths of bamboo join to make cross $\sim$ krosem tufala bambu i mit long antap blong haos

gemel traditional building used only by men of rank for ceremonial purposes and meetings $\sim$ nakamal gëv cover the ridge of a roof, where the two sides meet, make ridge flashing blokem top blong haos

gëv bulës make the ridge flashing for house roof using method of bending sago palm thatch over join wei blong blokem top blong haos we yu benem wan natanggura i go antap blong blokem top blong haos gëv gonsōgōrō make the ridge flashing for house roof by sewing together two slabs of sago palm thatch and placing on join wei blong blokem top blong haos wetem tu natanggura we yu somap tugeta mo benem antap long haos

gilgeg stand up post stanemap pos gonsōgōrō two pieces of thatch joined together to make one piece to cover over top of roof $\sim$ tu natanggura we ol i somap tugeta blong kavremap top blong haos

gövruqō thin length of bamboo tied onto edge of thatching on roof to hold the thatching tight $\sim$ longfala bambu we $\mathrm{i}$ tintin we ol $\mathrm{i}$ fasem long en blong natanggura blong i holem taet

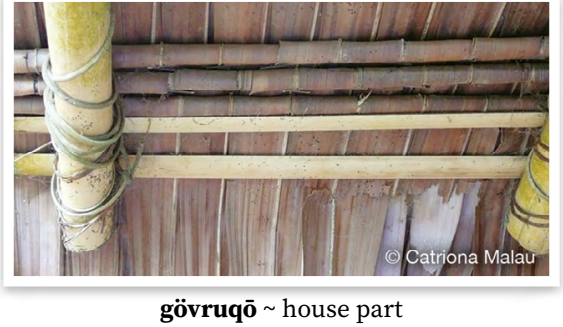

gövur house, generic name for building haos

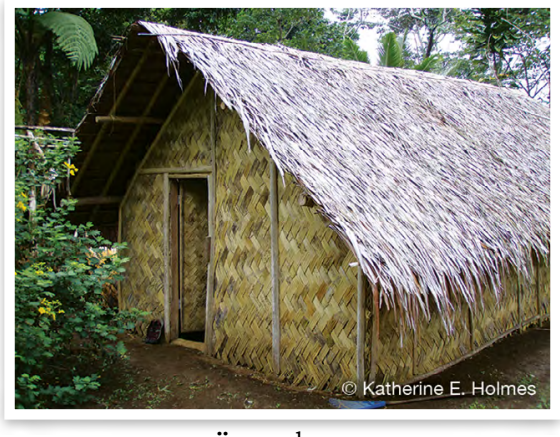

gövur gōrōn̄ church jos

gövur lisia hospital, clinic klinik

gövur tatar church jos

kulë gövur back, sides and roof of house, sections of house behind the front $~$ baksaed blong haos, we $\mathrm{i}$ kavremap saed mo ruf

nögö gövur front of house fored blong haos

lëk nail piece of timber on outside of bamboo walling to hold it in place putum strap long haos

lōlō count how many rows of thatching are needed to make roofing $\sim$ faenemaot hamas ro blong lif (masa) i nidim, sapos yu no makem fastaem

masa row of slabs of thatch that make up roofing ro blong pis natanggura we ol i bin fasem blong mekem rufing blong haos

masa dirdir short slab of thatch that is made if there is a short row left at the end when you are thatching 
a roof $\sim$ pis natanggura blong ruf we ol i mekem i sotwan blong filimap ples long en

masa taq side of roof that has more slabs saed blong ruf blong haos we hem i gat moa natanggura long hem masa tur side of roof with less slabs $\sim$ saed blong ruf blong haos we natanggura i no fulap

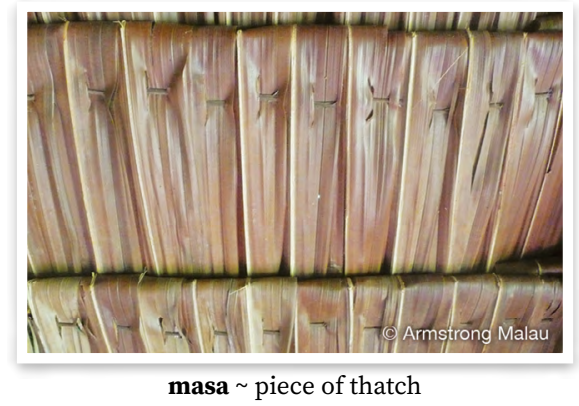

mete gövur door doa

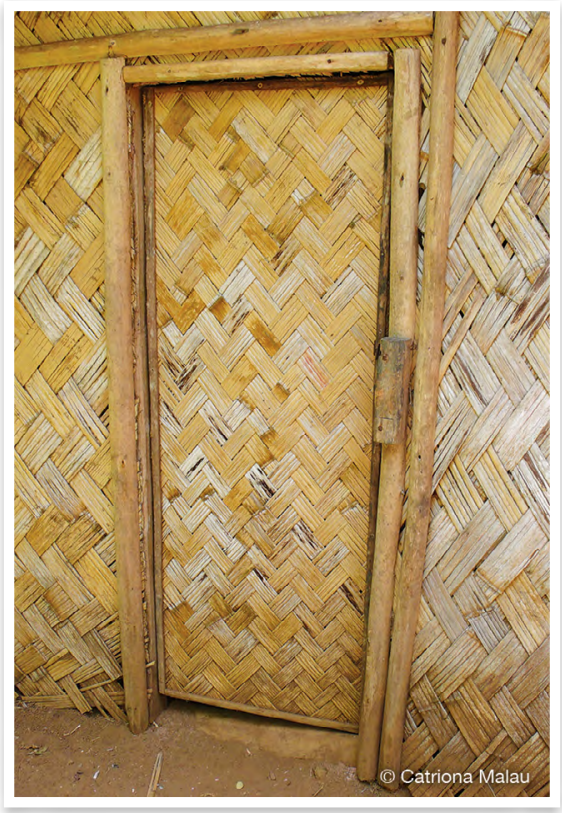

mete gövur door

mun mend roof of house by changing individual pieces of thatch $\sim$ jenesim wanwan lif natanggura insaed long haos mēēē tele weaving pattern, for which two strands are woven over, two strands under, alternating the smooth side facing out, then the rough side facing out, can refer to bamboo walling, coconut, pandanus stael blong wiv we tu pis i go ova, tu pis i go andanit, mo yu jenisim, wan antap blong lif o bambu, narawan andanit blong hem

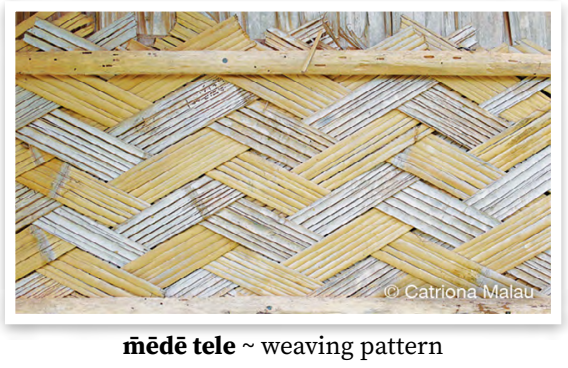

$\mathbf{r o ̄} \mathbf{q}_{2}$ bend length of bamboo over the top of the house in making roof putum bambu i go ova long top blong mekem haos

sagar remove damaged piece of thatch from roof $\sim$ tekemaot olfala lif natanggura bifo yu mekem niu wan bakegen

sañ ${ }_{1}$ house post pos blong haos sañ tine central post of house medel pos blong haos

san̄möt part of house pat blong haos sasal tie lengths of unsplit bamboo together to make walling for house wei blong mekem wol blong haos we yu dabolem ol pis bambu

so cut sago leaves, bring and prepare thatch $\sim$ mekem natanggura

so gamēlēs remove midrib from sago palm but don't remove it all, and therefore the leaf will snap when you try to bend it to make thatch karemaot bun blong natanggura be yu no karemaot gud

sus $_{3}$ place marker to indicate position of house posts stikim mak, wud folem mak blong haos 
teren make walling of house by lining up and tying together lengths of bamboo laenemap mo fasem ol bambu blong mekem wol blong haos

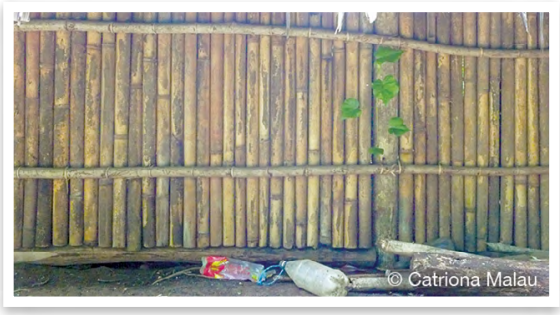

tereñ $\sim$ make walling

varar weaving pattern where two strips are woven under, two over; term used for weaving pandanus, coconut leaves, bamboo walling stael blong wiv we tu pis i go ova, tu pis i go anda; stael ia hem i blong pandanas, kokonas o bambu blong haos

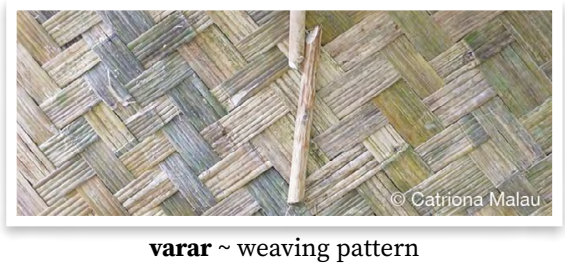

varar tur two over, two under weaving pattern, straight up and down stael blong wiv we tu pis i go ova, tu pis i go anda, i stanap stret

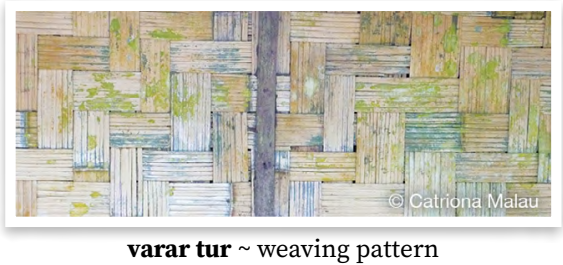

vēn make thatch slabs for roofing

by pinning sago palm leaves over a length of reed $\sim$ pinim lif natanggura waatlëk part of house pat blong haos weselegōsōw part of house pat blong haos weseñebēr part of house pat blong haos

wēbēr beam rel

wētēsi gövur frame of house inside house that is used when building to sit on so that you can reach the roof to sew on the thatch $\sim$ smol brata blong haos, lada blong stanap long hem blong fasem haos

wētilmal part of house pat blong haos

wètilvarvar part of house pat blong haos

wëlëklëk strap, thin piece of timber used in house construction to hold bamboo walling in place strap, wud blong holem taet woling blong haos

winir (fr.var. wēnir) house walling made from trunks of tree fern woling blong haos we ol i mekem long blakpam

wōlōwōl cross, cross beam kros, kroswud blong haos, kros blong Jisas

wōrōqrōq bamboo rafter of house bambu blong somap lif long hem

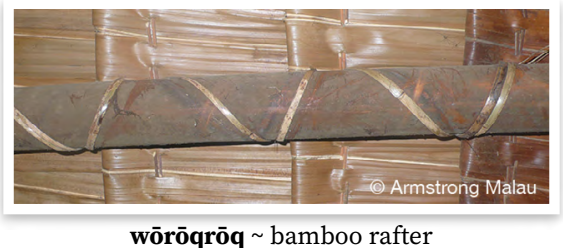

wōtōg reed that is used to sew sago onto to make thatching rid we ol i yusum blong pinim natanggura long hem, mo tu wan pis blong taj wōtōw measurement unit for roof thatching pis natanggura we ol $\mathrm{i}$ mekem finis

wöqut corner kona

wuduw sharp needle-like piece from inside of base of sago palm rachis bun we i kamaot long insaed blong stamba blong lif natanggura 


\section{M2.2 Furniture}

abawē pandanus mat pandanas mat be relational classifier used to mark possession of items that are used for bedding by the possessor $\sim$ blong (yusum blong tokbaot ona blong bed o samting blong slip)

ban her/his/its (things for bedding) $\sim$ ting blong slip blong hem

ben i nötuk my child's (bedding) ting blong slip blong pikinini blong mi

bëk my (things for bedding) ting blong slip blong mi

döñ coconut leaf mat $\sim$ lif kokonas mat

qetōlōñ pillow pilo

tētēr ${ }_{2}$ mirror glas, miro

tönö sigsiag seat, chair, stool, bench ples blong sidaon, jea

tönöam bed or sleeping mat bed o mat we yu leidaon long hem

wēqē shelf, bed, storage platform bed

wēqē n̄e shelf built over fireplace for smoking canarium nuts $\sim$ bed we ol i bildim ova long faea blong smokem nangae

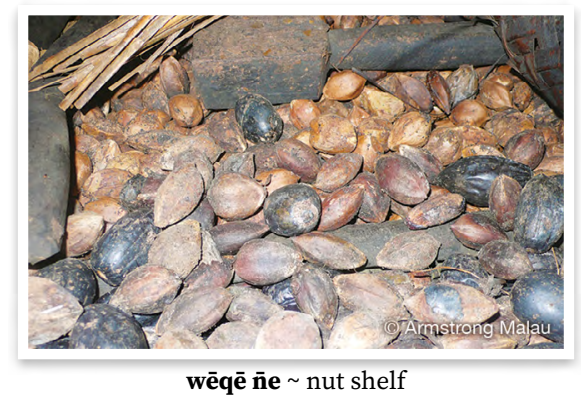

M3 Clothes, materials and decorations

ber $1 \cdot 1 \cdot$ grass skirt, skirt made from beach pandanus $\sim$ grasket

bōñ baby sling, cloth used for carrying baby kaliko blong karem pikinini bul tattoo tatu

gabelte belt $\sim$ strap

gogov $\mathbf{1} \cdot$ clothes $\sim$ klos $2 \cdot$ cloth $~$ kaliko

metegongon zip, opening of trousers

sipa, samting blong blokem fran blong traosis

mölö clothes klos

molon her/his clothes $\sim$ klos blong hem

mölök my clothes klos blong mi

rēn̄ëg wear around neck hangem long nek

sagēl decorate, as with flowers and colourful leaves, or planting colourful plants on boundary dekoreitem, olsem yu putum flaoa long haos o planem kalakala flaoa long eria

sër ${ }_{3}$ wear, put on (clothes, accessories) $\sim$ werem, havem (klos, savat)

sër $1 \overline{\mathbf{o}}$ take off, remove (clothes, accessories) karemaot (klos)

sot shirt $\sim$ sot

timiat headdress worn by men for particular dances hedres we ol man i werem long taem blong danis walal $_{2}$ bracelet $\sim$ breslet wetenge necklace $\sim$ nekles

wevet necklace $\sim$ nekles

wērērēnēeg necklace, something that is worn around one's neck nekles, samting we yu hangem long nek blong yu

wësërsër clothes klos

M4 Weaving, woven goods

abawē pandanus mat pandanas mat bès ${ }_{1}$ prepare cane or vine for weaving by stripping woody insides from outer bark karemaot insaed blong loeaken o rop, redi blong wivim

bor 2 1 kind of large coconut leaf basket which is used for transporting food wan kaen basket blong lif kokonas we ol i yusum blong 
paselem plante kakae insaed olsem blong sanem $\mathbf{2} \cdot$ small basket that is filled with food and hung up outside someone's house to indicate that another person has failed to meet an appointment, such as for a meal or drinking kava, with that person. The community will then know that this person has been let down by another basket we man i fulumap wetem kakae mo hangem aotsaed long haos blong ol man ol i save se wan narafala man i mestem mo i no kam taem hem i bin mekem promes wetem man we i hangem basket ia

dēmērir pandanus that has dried on the plant pandanas we i drae long stamba

dērēs tear strip from edge of coconut or pandanus leaf to make narrower for use in weaving teremaot pat blong lif kokonas o pandanas sapos i bigwan tumas taem yu wantem wiv
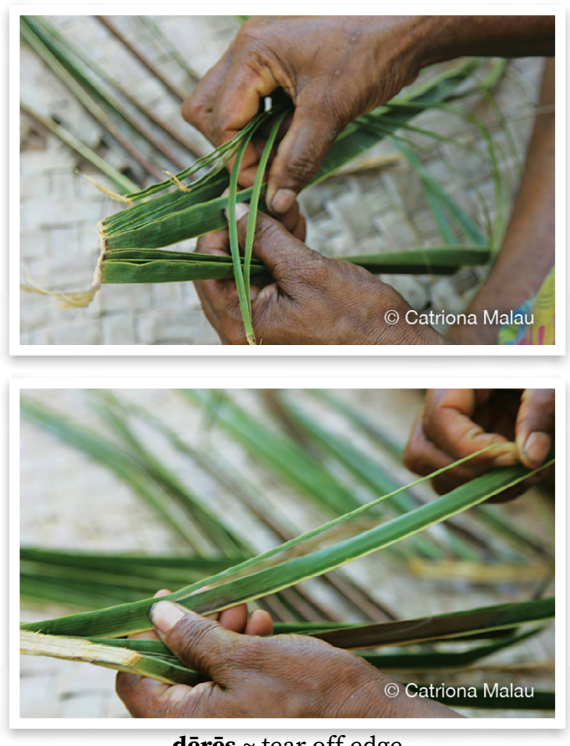

dērēs tear off edge dērivriv (fr.var. dirivriv) fan $\sim$ fan

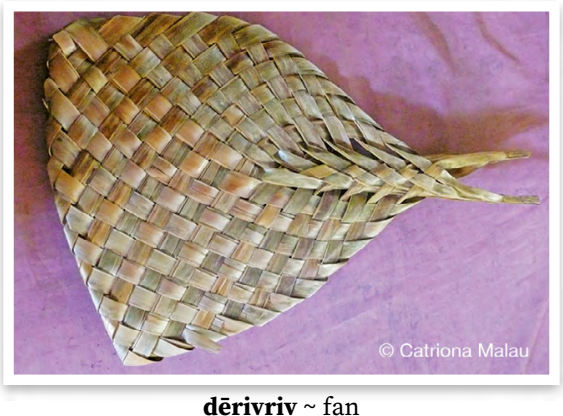

dön coconut leaf mat lif kokonas mat

dötösqar green (undried) pandanus leaf grin lif blong pandanas

gakarēs kind of climbing fern wan kaen rope Lygodium reticulatum

gamalwuw kind of black vine wan kaen rop we i stap long bus mo hem i blak Smilax vitiensis

gamērēr kind of vine wan kaen rop Freycinetia spp.

gamērēr dēmadēm kind of vine wan kaen rop Freycinetia flavida

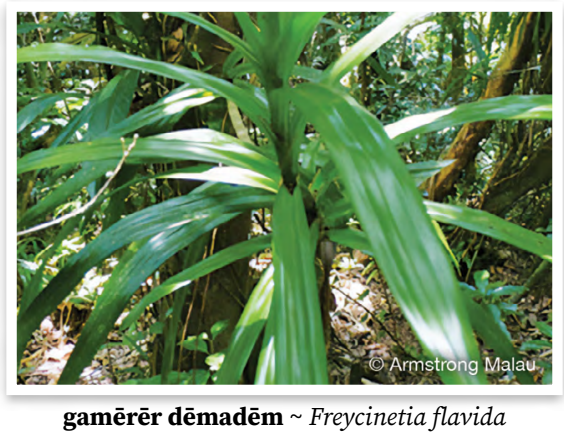

gamērēr qō kind of vine wan kaen rop Freycinetia impavida

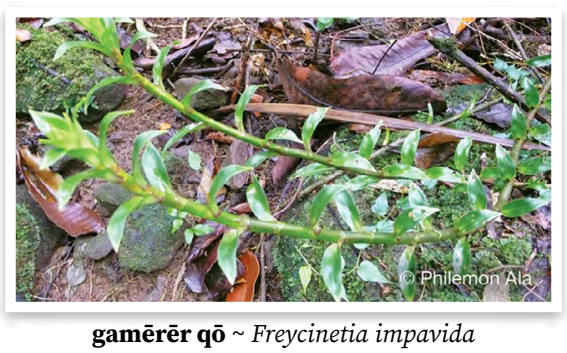


garte wōl kind of basket, with curved base wan kaen basket we hem i sep olsem hafmun

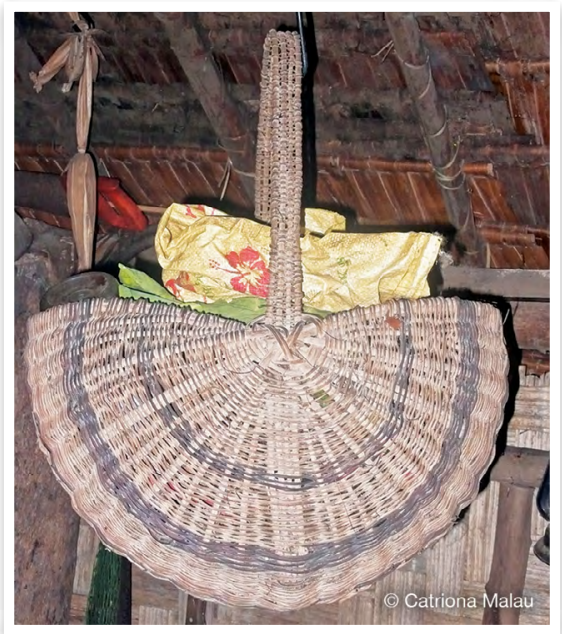

garte wōl kind of basket

gateteg kind of basket made from coconut leaves and used for carrying firewood wan kaen basket blong faeawud we ol i wivim long lif kokonas

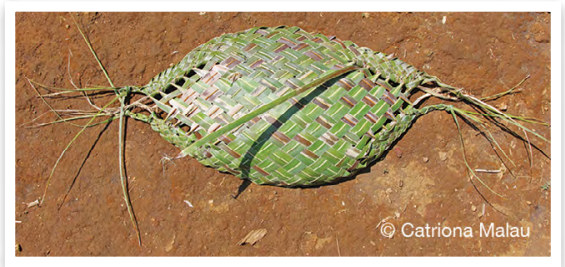

gateteg kind of basket

gavan̄ kind of food basket woven with a black vine, gamalwuw wan kaen basket blong kakae we ol i wivim wetem blak rop

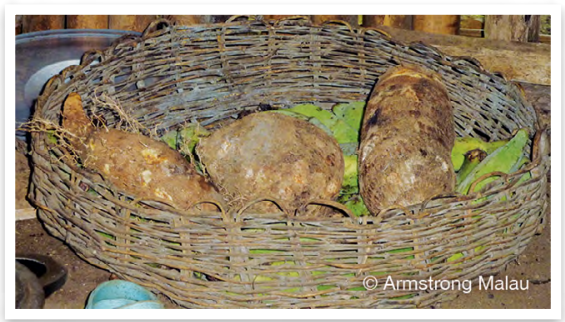

gavañ $~$ kind of food basket girir smooth out pandanus leaves using limpet shell, in preparation for weaving smutum pandanas wetem sel, redi blong wivim
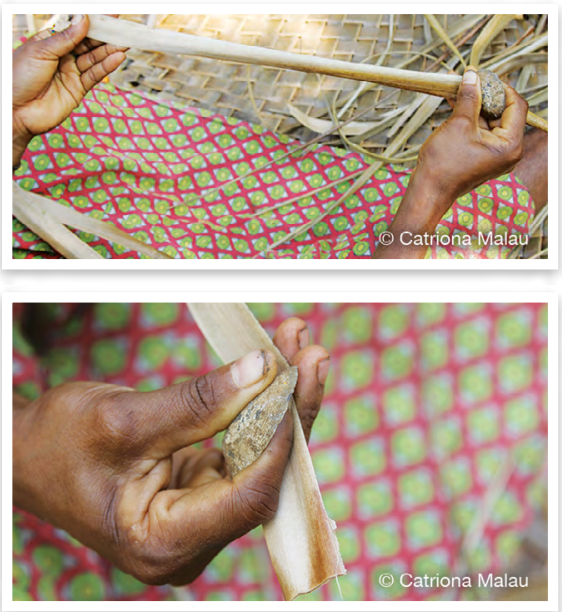

girir smooth pandanus

matqēt flat coconut leaf basket which is used especially in cooking, as a scraps basket and also for placing parcels of hot cooked food inside basket blong lif kokonas we hem i flat mo ol i yusum long saed blong kuk blong putum kakae o doti blong kakae insaed

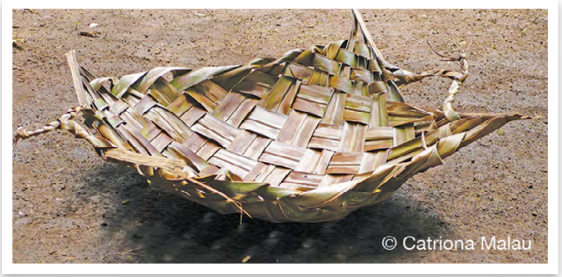

matqēt flat coconut leaf basket

mēèdē tele weaving pattern, for which two strands are woven over, two strands under, alternating the smooth side facing out, then the rough side facing out, can refer to bamboo walling, coconut, pandanus $\sim$ stael blong wiv we tu pis i go ova, tu pis i go andanit, mo yu jenisim, wan antap blong lif o bambu, narawan andanit blong hem 
misiak coconut leaf mat with only one side lif kokonas wetem wan saed nomo

$\operatorname{nin}_{1}$ split leaf or leaflet in two along midrib, split length of vine or cane into strips splitim lif, karemaot bun blong lif

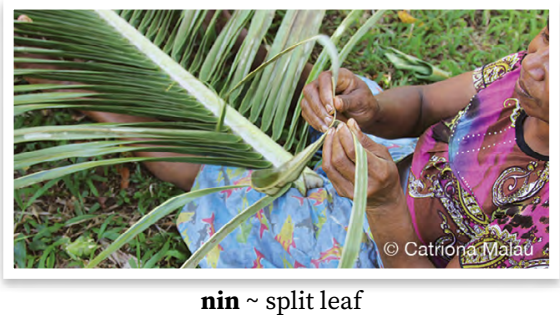

qeleg plait together two strips of coconut leaflets or pandanus leaves as first stage in making basket or mat joenem tugeta tu saed blong lif kokonas o pandanas blong wivim
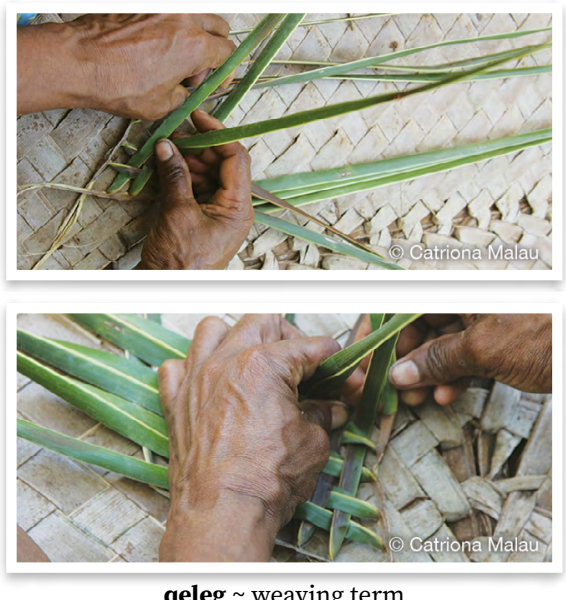

qeleg weaving term

qörö ${ }_{2}$ strip of coconut leaflets incorporated into basket to form corner pis lif kokonas we ol i ademap long basket blong mekem kona blong hem

qötuōw kind of basket made from coconut leaves and hung in the kitchen, used especially for putting bivalve shells in, which are used for scraping food and coconuts wan kaen basket we ol i mekem long lif kokonas mo yusum blong putum plasta sel insaed long kijin

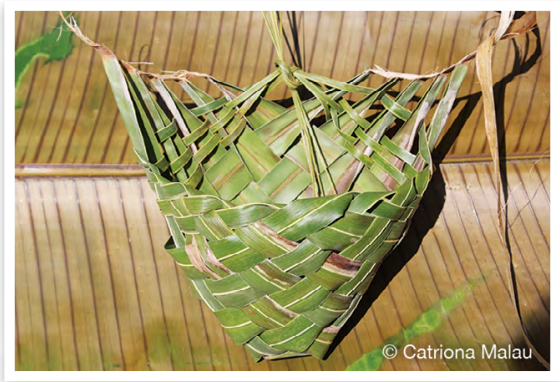

qötuōw kind of basket

ran̄ōrō plait, weave twill pattern; plait strips over two crossing elements wivim tutu, wivim pis pandanas o bambu i go ova long tu narafala pis, i no wan nomo

rēvōrō weave two strands over and two strands under $\sim$ wivim tu i go antap, tu i go andanit

ro soak, immerse in water $\sim$ draonem long wota

sergeg (after plaiting together sections composed of two pandanus half leaves) lay sections down, overlapping, ready to plait together $\sim$ tekem ol pis pandanas we yu bin wivim tu lif tugeta, joenem plante tugeta blong statem mat

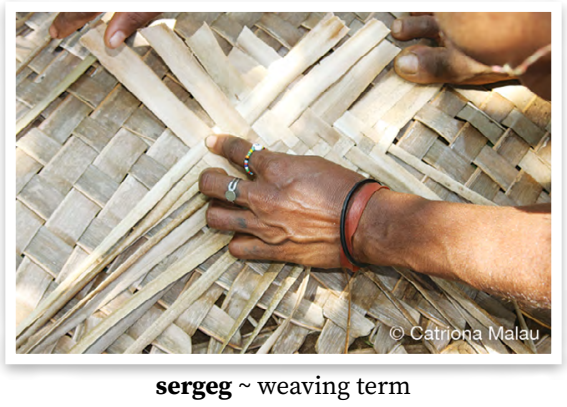

susuñu make fringe (on mat or cloth) $\sim$ katem pisisim en (blong mat o kaliko) 
tamn̄o coconut leaf mat lif kokonas mat

tan̄ pandanus basket, usually small, especially one used for carrying personal effects, also for collecting nuts or small amounts of food basket pandanas, blong yusum blong ol smolsmol ting blong yu

tiam $_{2}$ upsett (basket), prepare to weave, plait sides (of basket) leftemap basket, redi blong wivim saed blong hem

tibiar basket, generic term used to refer to coconut leaf, pandanus and cane or reed baskets basket, nem ia i kavremap ol kaen basket blong kokonas, pandanas mo narafala kaen

tibiar gamalwuw kind of food basket woven with a black vine wan kaen basket blong kakae we ol i wivim wetem blak rop

tig finish (basket or mat) by plaiting or threading in ends to prevent from coming undone $\sim$ finisim ol sotsot pis blong pandanas o rop blong mat o basket blong mekem se ol i no save kamkamaot

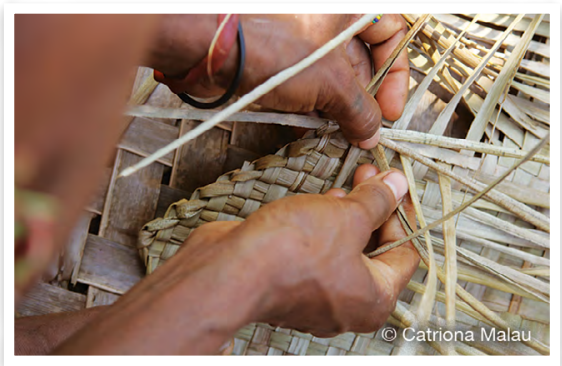

tig weaving term

toq bottle shaped basket which is used for storing dry canarium nuts basket blong fulumap drae nangae insaed we hem i sep olsem wan bigfala botel

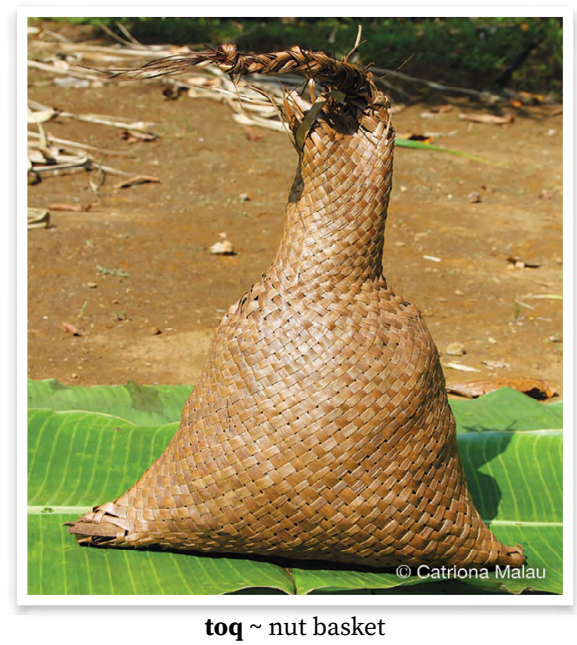

tönöam bed or sleeping mat bed o mat we yu leidaon long hem

tös strip thorny edges (of pandanus) with needle-like instrument and split into strips ready for weaving $\sim$ splitim pandanas smolsmol mo tekemaot bun o nil

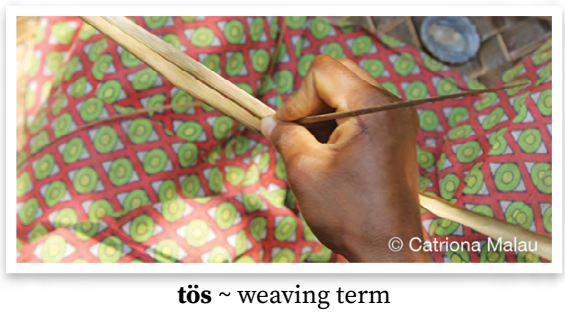

varar weaving pattern where two strips are woven under, two over; term used for weaving pandanus, coconut leaves, bamboo walling stael blong wiv we tu pis i go ova, tu pis i go anda; stael ia hem i blong pandanas, kokonas o bambu blong haos

varar tur two over, two under weaving pattern, straight up and down stael blong wiv we tu pis i go ova, tu pis i go anda, i stanap stret 
vet ${ }_{2}$ plait, weave [refers both generally to interlacing of sets of elements (as plaiting of coconut leaves, pandanus) and specifically to interlacing of a set of weft elements across fixed warp elements] wiv, wivim

vetvet weaving, in process or completed items $\sim$ wiving we i stap mekem o i mekem finis
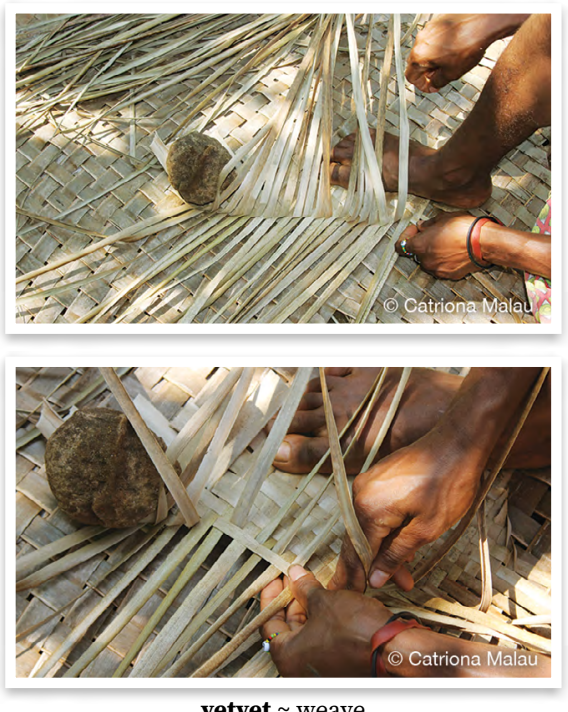

vinit plait in additional pandanus leaf strips to create second side of pandanus mat joenem lif pandanas blong statem narafala saed blong mat

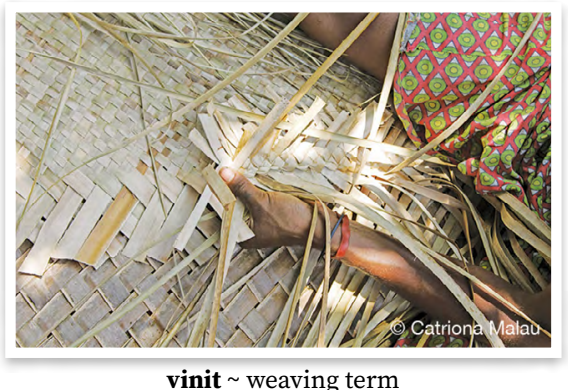

vir plait, braid, French braid, plait a cord $\sim$ tanem (hea o rop o saed blong mat)

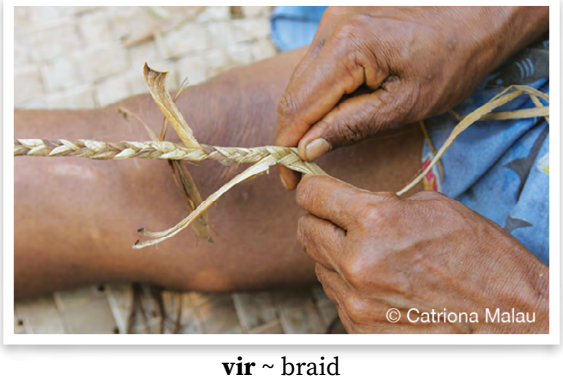

gavirvir braid, French braid rop we ol i tanem

vudege (fr.var. vudëgë) pandanus, screw pine pandanas Pandanus spp.

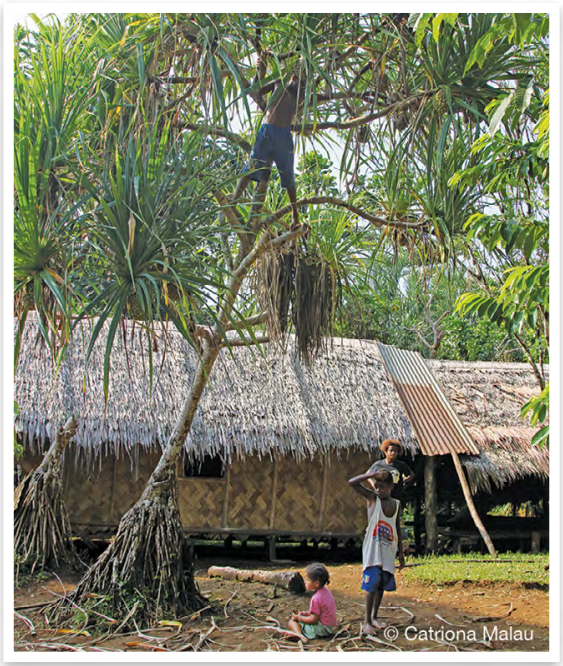

vudege $\sim$ pandanus

waga $_{1}$ basket trap for catching freshwater prawns $\sim$ basket blong kasem naora

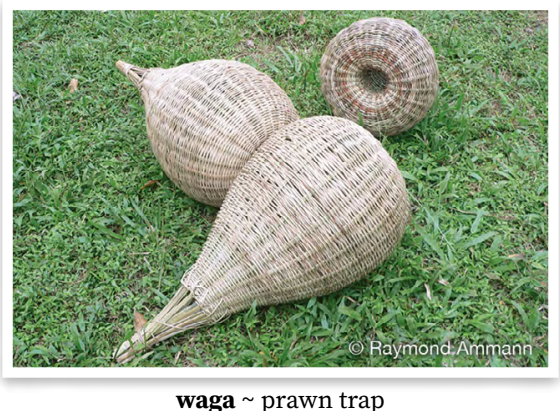

waga $\sim$ prawn trap 
wamase $\overline{\mathbf{e}}_{2}$ kind of basket, shaped like a star wan kaen basket we i gat sep olsem sta

weteñe tō basket traditionally used for keeping chicks in to feed them, which now has other uses, made from Donax canniformis and woven in lattice style $\sim$ basket blong kipim smol faol insaed blong fidim

wēgèbil ${ }_{2}$ kind of small coconut leaf basket that is used especially when reef gleaning, for putting shellfish in kaen basket blong lif kokonas we ol i yusum taem ol i go karem mit long solwota, blong fulumap ol sel insaed long hem

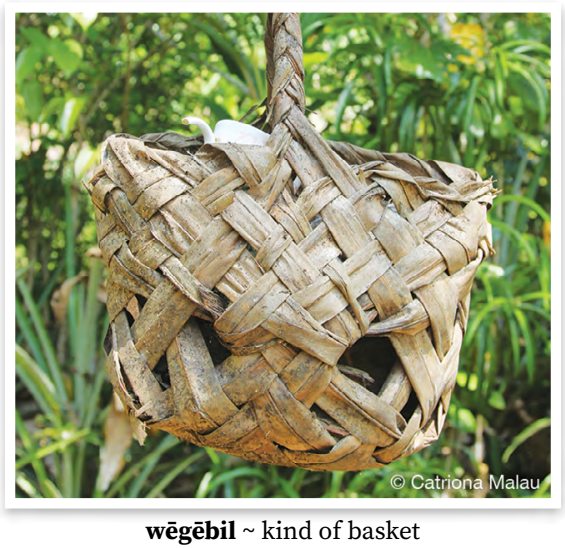

wēgèt kind of coconut leaf basket used for holding and transporting food wan kaen basket blong lif kokonas we ol i yusum blong karem kakae long garen o hangem kakae long hem

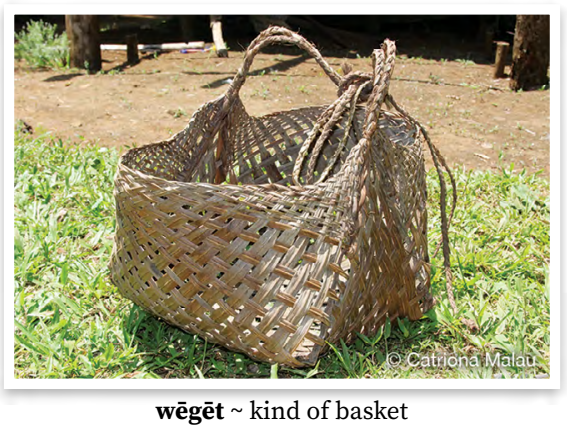

wōōr kind of woven basket that has a base and is made from rattan, woven with Freycinetia vines and lengths of Lygodium fern kaen basket we ol i wivim long rop mo fens

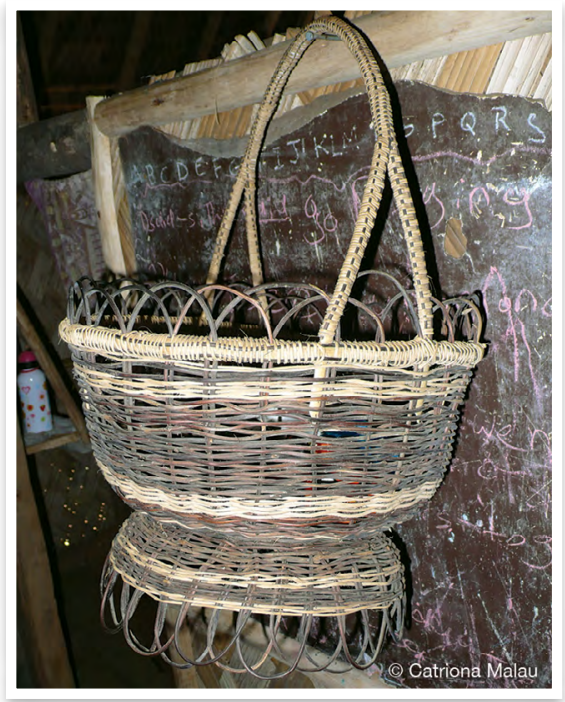

wōōr $\sim$ kind of basket

wösurtege kind of pandanus basket that has two plaited straps for carrying, used for carrying cooked food and general items wan kaen basket blong pandanas we i gat tu rop blong karem, we ol i yusum blong karem kakae mo ol smol samting

wöwöwör qēsaqēs kind of trap used close to the shore for catching small fish and particularly lobster kaen trap we yu yusum klosap long so blong kasem ol smol fis mo speseli naora

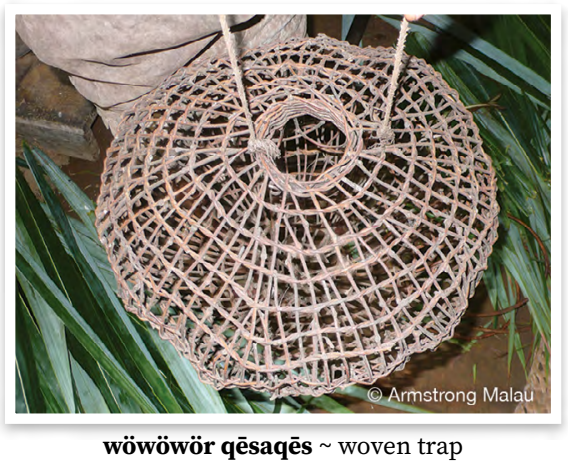


wuduw sharp needle-like piece from inside of base of sago palm rachis bun we i kamaot long insaed blong stamba blong lif natanggura

wususrō kind of basket made from coconut leaves, used for carrying food and firewood kaen basket blong lif kokonas we ol i yusum blong kakae mo faeawud

\section{M5 Nautical}

ak canoe, boat, ship kenu, sip ak geben sailing canoe $\sim$ sel kenu ak sōsō canoe kenu

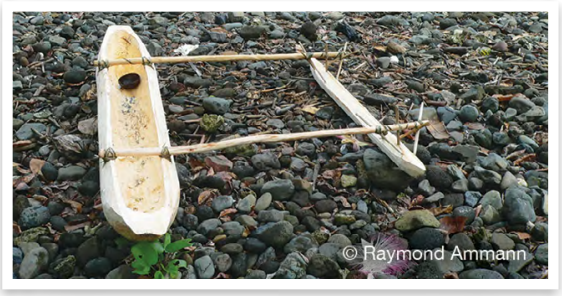

ak sōsō $\sim$ canoe

bakalav $_{1}$ ship sip

bertañtan feel body of canoe to test whether it is thick or not, to see if it needs to be hollowed out more holem bodi blong kenu blong testem se i tik o no

buswōtōt wooden stakes hammered into float to join float to cross booms of outrigger $\sim$ smol wud we i holem taet rel $\mathrm{i}$ joen long nasama blong kenu

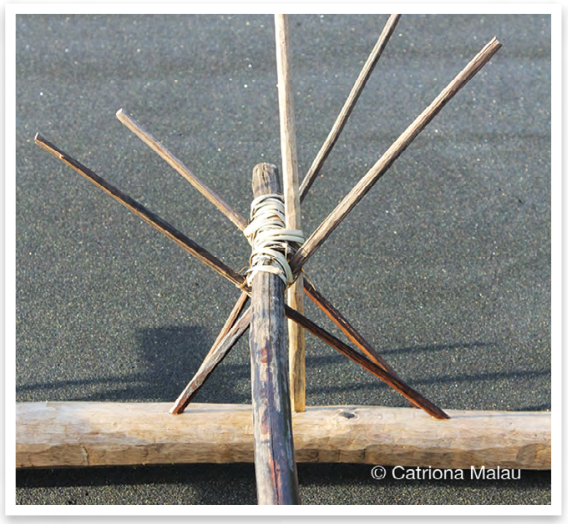

buswōtōt outrigger stakes ēwatē wooden sticks used to join crossboom to outrigger boom of canoe and hold it in place $\sim$ smol wud we i nilim wud i go long nasama blong kenu blong holem taet

geben sail sel

kewō large canoe bigfala kenu

qetegak captain, leader $\sim$ kapten, lida rës bail (water) belaot

sam outrigger float $\sim$ nasama

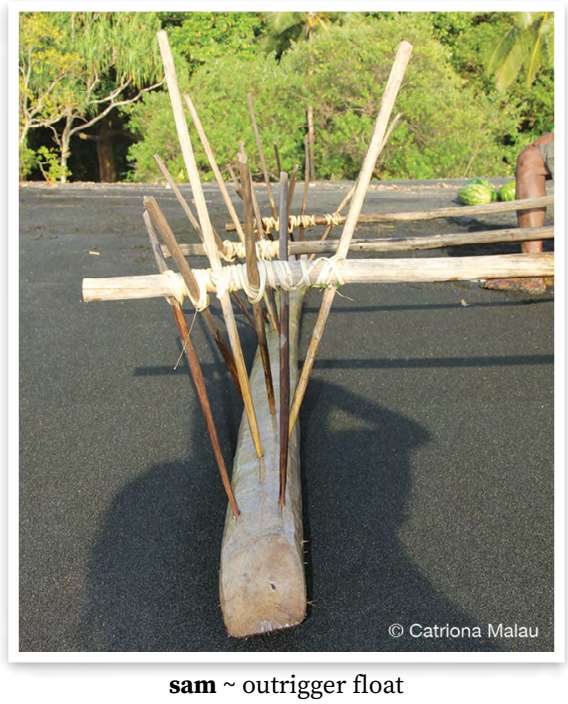

sō paddle parel, pul long kenu

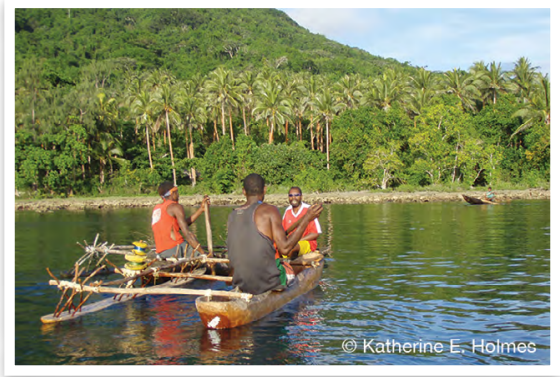

$\mathbf{s o ̄} \sim$ paddle

vasēlē launch (canoe) lonjem, putum (kenu) i go long solwota vidëm adze, tool for hollowing out canoe aj, tul blong katem kenu wēlwēl canoe kenu wërësrësak bailer, bailer for canoe samting blong belaot wota long kenu 
wōs 1 paddle (for canoe) parel (blong kenu)

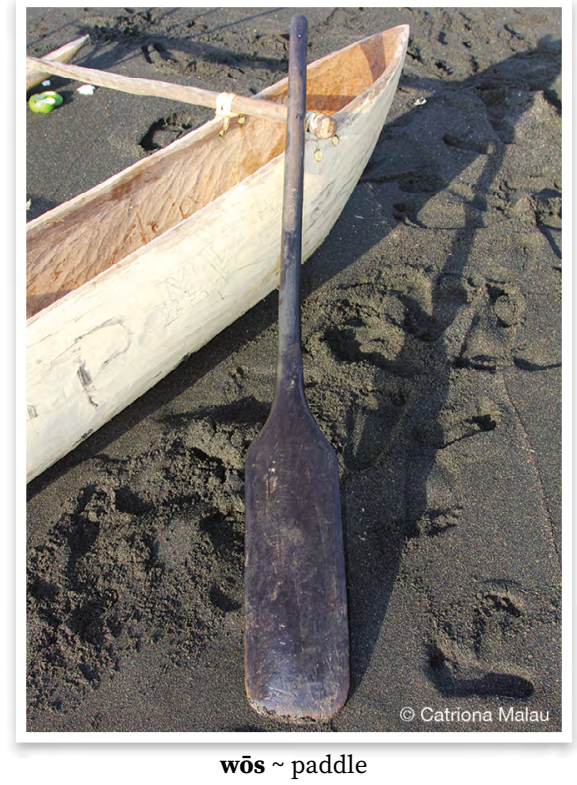

M6 Transfer of goods

baon 100 vatu, monetary unit used to refer to multiples of 100 vatu 100 vatu

bël $1 \cdot$ steal stilim

bit break off length of shell money $\sim$ karemaot pis sel mane

dalagē payment of bride wealth braed praes

girēe buy pem

girē qalēg (at marriage ceremony) give money to parents of husband, to confirm their relationship status as in-laws long taem blong mared woman i givim mane long ol papa mo mama blong boe

girē wël (at marriage ceremony) give money to sisters of husband (for woman) to confirm their relationship status as in-laws $\sim$ long taem blong mared woman wetem ol famle blong hem ol i givim smol mane long brata mo sista blong boe mil 1,000 vatu, monetary unit used to refer to multiples of 1,000 vatu 1,000 vatu

masar poor person, who has no valuables, such as pigs and other valuable goods, money and land pua man we hem i nogat ol samting olsem pig mo narafala samting we $i$ gat valiu blong hem

nereg sell salem

rēq pay fine for saying the name of your parent-in-law or child-in-law, or otherwise not showing respect to them pem smol faen sapos yu no bin respektem gud palika blong yu, olsem yu singaotem nem blong palika o yu ovarem hem

rēqrēq fine paid for saying your parent or child-in-law's name or otherwise not showing respect to them $\sim$ faen blong pem sapos yu no bin respektem gud palika blong yu, olsem yu singaotem nem blong palika o yu ovarem hem

selen 1 - 10 vatu, 10 vatu coin, monetary unit used to refer to multiples of 10 vatu, up to 100 vatu 10 vatu, koen we i gat valiu blong 10 vatu mo yu save ademap kasem long 100 vatu $\mathbf{2}$ • money, general term for money mane

ser ${ }_{3}$ pay back, return money in exchange for something given pembak

söm $\mathbf{1} \cdot$ money mane $\mathbf{2} \cdot$ shell money, traditional money, used as a value item for trading and payments in cultural exchanges sel mane we ol i bin yusum bifo blong pem ol samting long kastom

tabēva present $\sim$ presen

tiveg 1 - money, payment for something mane, amaon blong pem from wan samting 2 - pay (someone, something) pem

tun $_{2}$ buy land from another tribe pemaot graon long narafala traeb long kastom 
wadē money mane

wöl $\mathbf{1}$ • buy, purchase pem $\mathbf{2} \cdot$ pay (someone), compensate $\sim$ pem 3 . pay bride wealth for $\sim$ pem (woman) wölwöl shopping soping

\section{M7 Vehicles}

ak canoe, boat, ship kenu, sip ak gavgav plane $\sim$ plen

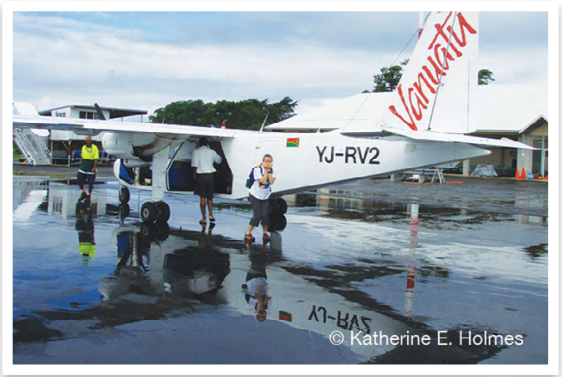

ak gavgav $\sim$ plane ak geben sailing canoe $\sim$ sel kenu

ak sōsō canoe kenu

$\mathbf{k e}_{3}$ relational classifier used to mark ownership of forms of transport, such as a canoe blong (yusum blong tokbaot ona blong kenu o trak) kan her/his/its (canoe) blong hem (kenu)

ken tëmëk belonging to my father (canoe) blong papa blong mi (kenu)

këk my (canoe) blong mi (kenu) plen plane $\sim$ plen susuki motorbike $\sim$ moto trak vehicle, car, utility vehicle $\sim$ trak wēvēvērēg vehicle, general term for car, utility vehicle, truck trak

\section{N Kinship}

\section{N1 Kin terms}

bērn̄ē partner, friend, person one associates with patna, fren

bērn̄ēn her/his/its partner patna blong hem

bērn̄ik my partner patna blong mi

Bum Grandma, Grandpa, Grandchild; reciprocal address term used by grandparent to grandchild or grandchild to grandparent $\sim \mathrm{Bubu}$

Bum tal Great-Grandma, GreatGrandpa mama o papa blong bubu

Bum vövörus Great-great-grandparent Bubu blong bubu

Die Mum Mama

Diebum Grandma Bubu woman

die 1 - mother (generic) mama 2 • call (someone) mother $\sim$ singaotem mama long

gunö spouse man blong woman; woman blong man ginon her/his spouse $\sim$ man/woman blong hem

gunök my spouse woman/man blong mi

Ika $1 \cdot$ wife, used as an address term $\sim$ waef, olsem yu singaot long hem

malaen ex-wife, ex-husband olfala woman o man blong yu blong bifo we yu nomo stap wetem hem

Mam $1 \cdot$ Dad Papa

Mambum Grandad, Grandpa Bubu man

maröu maternal uncle; brother of mother, husband of sister of father angkel

marōōn her/his uncle angkel blong hem

maröuk my uncle angkel blong mi nötu 2 child (of), offspring pikinini (blong hem) 
nōtōn her/his/its child pikinini blong hem

nötuk my child pikinini blong mi Qalēg reciprocal term used to address parents of spouse or spouse of child, father-in-law, mother-in-law, daughter-in-law, son-in-law palika qelge reciprocal term used to refer to parents of spouse or spouse of child, father-in-law, mother-inlaw, daughter-in-law, son-in-law palika, papa o mama blong man o woman blong yu, man o woman blong pikinini blong yu

qelgan her/his parent-in-law palika blong hem

qëlgëk my parent-in-law palika blong mi

rētne mother (of someone) mama (blong)

rētnan her/his/its mother mama blong hem

rētnëk my mother mama blong mi

Rëwël brother-in-law; wife's brother, sister's husband (for man), reciprocal same generation in-law address term for men $\sim$ brata blong woman blong man, man blong sista blong man

savan which relative of him/her, or which part of his/her body? wanem famle blong hem, o wanem pat blong bodi blong hem?

sian gōgōn name that one uses to refer to or address someone who has the same name as an in-law whose name you are unable to say, due to cultural restrictions of the relationship nem we yu yusum blong talemaot wan man o woman we hem i gat semak nem olsem wan tawian o palika blong yu, from we nem i semak, i tabu blong singaotem nem

sögö moiety, descent group laen sogon her/his descent group laen blong hem sögök my descent group laen blong mi

Tatat (abbrev. Tat) Uncle, address term used towards uncle Angkel, nem we yu singaot long angkel

tawian brother-in-law, sister-in-law tawi, tawian

teme father, father's brother papa blong hem

taman her/his father papa blong hem

tëmëk my father papa blong mi

tèsi younger same sex sibling smol brata blong wan boe o smol sista blong wan gel

tasēn her/his/its younger sibling smol brata o sista blong hem

tēsi rësrës youngest sibling lasbon brata, sista

tēsik my younger sibling smol brata o sista blong mi

tētē $\mathbf{1} \cdot$ baby bebe, smol pikinini 2 - My child, term of endearment used by parent to child $\sim$ Bebe, nem we mama o papa i yusum blong singaotem smol pikinini blong hem

tōgan her/his/its older same sex sibling big brata blong wan boe o big sista blong wan gel

tubu 1 - grandparent, grandchild, reciprocal term used between grandparent and grandchild $\sim$ bubu, smol bubu $\mathbf{2} \cdot$ ancestor $\sim$ bubu blong bifo

tōbōn her/his grandparent/ grandchild bubu blong hem tubuk my grandparent/grandchild bubu blong mi

Tutu address term used towards opposite sex sibling, brother (of a girl), sister (of a boy) brata blong wan gel o sista blong wan boe

tutue opposite sex sibling, brother (of a girl), sister (of a boy) brata blong wan gel o sista blong wan boe 
tōtōan her/his/its opposite sex sibling brata blong hem (blong gel) o sista blong hem (blong man)

tutuen Hilton Hilton's sister sista blong Hilton

tutuëk my brother (for girl), my sister (for boy) brata blong mi (gel i toktok) o sista blong mi (boe i toktok) vann̄on niece, nephew, child of sister (of a man) smol angkel, pikinini blong sista blong wan man

Vann̄ö niece, nephew, child of sister (of a man) smol angkel, pikinini blong sista (blong wan man)

Wimiar term of endearment used by parent-in-law to child-in-law nem we wan $i$ yusum blong singaotem palika blong hem, we hem i woman blong boe blong hem o man blong gel blong hem

wotwot kin relationship, one's father's mother's brother's children, reciprocally the same as one's father's sister's son's children, relationship between child of uncle and child of nephew (following male line only) $\sim$ famle memba we hem i pikinini blong angkel blong papa blong yu

Wölus sister-in-law; husband's sister, brother's wife (for woman), reciprocal same generation in-law term for women sista blong man blong woman, woman blong brata blong woman

\section{O Marriage, sex, nurturing}

\section{O1 Marriage and sexual relations}

bat go secretly in search of sexual partner krip from fren

bēl have sexual intercourse fak

bōbōn kiss kis, kisim

dalagē payment of bride wealth braed praes

irir reject spouse because you believe that they have been unfaithful (man o woman) i no wantem stap gud wetem woman o man blong hem from hem $i$ ting se hem $i$ gat narafala fren

lagē marriage mared

lagē gē tisē bad marriage, in that it is not correct according to the rules of tradition dictating whom one should marry mared we i no stret long kastom, olsem we wan i mared wetem famle

lagē gōwē good marriage, in that it is correct according to the rules of tradition dictating whom one should marry mared we i folem stret rod blong kastom leg marry (in church), be married mared (long jos)

legleg marriage ceremony (in church) mared (long jos)

leg verser a son marries daughter of an uncle and daughter marries son of the same uncle, so daughter is exchanged for son and there is no need to pay a bride price $\sim$ pikinini gel blong angkel i maredem boe blong nara angkel, mo narafala boe i maredem gel blong sem angkel bakegen, mekem se ol i eksjenisim pikinini mo i no nid blong pem woman, jas mekem kakae

legser man who promises to marry but then changes his mind $\sim$ no save mared gud

mökölage food and presents for the house given with bride price $\sim$ ol samting we ol i givim wetem braed praes olsem kakae mo ol samting blong haos 


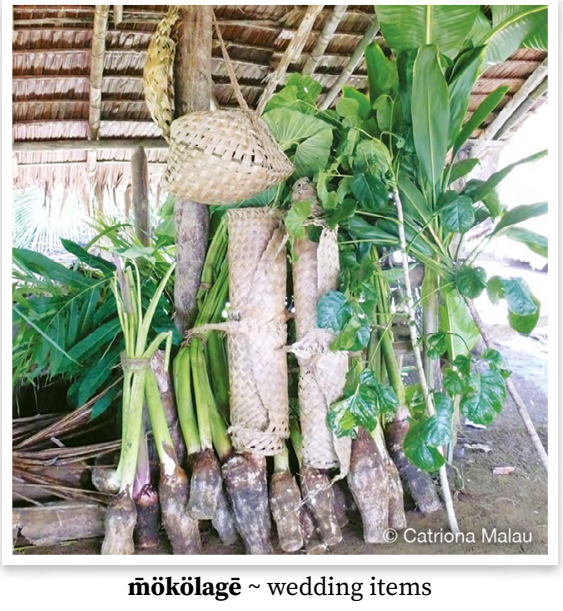

qalēg gōr make an agreement between the parents that a particular girl or woman will be married to a man blokem, putum tabu long wan gel mo givim mane se bae tufala i mared sersöm return some of bride price if a couple divorce, the woman's family must return money to the man's family who paid the bride price givim bak mane sapos mared i finis mo man mo woman i divos, famle blong woman i mas mekem long famle blong man we ol i bin pem woman ia

\section{O2 Pregnancy and childbirth}

ben rōrō placenta samting we $\mathrm{i}$ kamaot long mama, taem bebe i bon, we i bin fidim pikinini

be tētē $1 \cdot$ placenta samting we $i$ kamaot long mama, taem bebe i bon, we i bin fidim pikinini 2 uterus basket blong pikinini

dēm childless woman, woman who has never given birth woman we $\mathrm{i}$ neva karem pikinini

gösuv miar bathe baby in a traditional ceremony that occurs 5-10 days after the baby is born, the aunts of the child bathe the child and the father pays the aunts for this contribution $\sim$ faef o ten dei afta fes pikinini i bon, ol sista blong papa ol i kam wasem pikinini mo flasem hem mo afta papa i mas pem olgeta miarmōvōl stillbirth pikinini we hem i ded taem hem i bon

miarōbōl new mother, mother who has recently given birth mama blong smol bebe

tel (abbrev. of telsiër) be pregnant, become pregnant $\sim$ gat bel

vawot give birth bonem

völöt traditional practice in which when the first child of a couple is born, the family of the mother come and try to throw stones at the father of the child and his family taem fes bon pikinini i bon, famle blong mama ol i traem stonem papa blong pikinini wetem ol famle

vösus give birth, lay egg bonem, karem pikinini, putum eg

wot 1 - born, be born bon

wotoqtoq $_{1} \mathbf{1} \cdot$ be pregnant $\sim$ gat bel $\mathbf{2} \bullet$ pregnant woman $\sim$ woman we $i$ gat bel

wōl $1_{1} \mathbf{3} \cdot$ month of pregnancy $\sim$ manis (blong woman we i gat bel) wōlan her Xth month (of pregnancy) $\sim$ manis blong hem

wulëk my Xth month (of pregnancy)

$\sim$ manis blong mi

\section{O3 Rearing babies and children}

datek $1 \cdot$ look after $\sim$ lukaotem

ēlgōr $1 \bullet$ look after, care for $\sim$ lukaotem 2 - watch out, be careful lukaot gōlōw orphan, child whose parents have died $\sim$ pikinini we $i$ nogat mama mo papa

$\overline{\mathbf{n}} \mathbf{a} \overline{\mathbf{n}}$ feed baby by chewing their food first to make it smooth, then feeding them fidim bebe, olsem yu juim kakae blong hem fastaem, afta fidim long hem taem i sofsosf

sus $_{4} \mathbf{2} \cdot$ suckle, suck on $\sim$ titi, titi long 


\section{P Speaking, communicaton and sounds}

\section{P1 Speaking}

aw shout, cry out $\sim$ singaot

baēr ask (someone) for something, ask (something) from someone askem wan samting long wan man

eln̄e $1 \cdot$ her/his/its voice $\sim$ voes blong hem 2 - words, opinion presented, what someone has said toktok folem tingting blong wan man

elñan her/his/its voice voes blong hem

elnëk my voice voes blong mi

elneul explanation $\sim$ toktok we i mekem i klia

eln̄evu traditional story kastom storian

gadödö qaqaq original, old-fashioned way of speaking olfala fasin blong toktok

gagneg tell, say to $\sim$ talem

gial $1 \cdot$ lie, tell untruth $\sim$ giaman $2 \cdot$ lie, tell untruth to $\sim$ giaman long gilgial lie giaman

kaka tell story, narrate $\sim$ stori

kakaka 1 - chat, speak storian, toktok $\mathbf{2} \cdot$ talk about, tell story about $\sim$ storian (long) $\mathbf{3} \bullet$ story, tale, speech $\sim$ storian

mamar ask of, plead, implore askem bigwan

òl 1 1 call, call out to $\sim$ singaotem ōlōl shout, call out $\sim$ singaot

qaq $\mathbf{1} \cdot$ say $\sim$ talem se $\mathbf{2} \cdot$ speak, talk $\sim$ toktok $3 \cdot$ language of a place lanwis

qaq ta minēn language of Vurës lanwis blong Vurës

qaq tala lam Bislama Bislama

sal 1 - message $\sim$ mesej $\mathbf{2} \cdot$ send message $\sim$ sendem mesej

sen lie, tell untruth giaman

suware invite $\sim$ invaetem tatar $1 \cdot$ pray $\sim$ prea $2 \cdot$ prayer $\sim$ prea

tono $\mathbf{1}$ - learn lanem $\mathbf{2}$ - teach, instruct $\sim$ lanem, tijim

vatvat 1 - promise, arrange, make agreement $\sim$ promes 2 - promise, agreement, arrangement $\sim$ promes

vetsur tell $\sim$ talem

vël ${ }_{2}$ answer, reply to ansarem, riplae long

vëlvël answer ansa

vörus ask (someone); ask (about) askem (man)

vörus völu question kwestin

P2 Interjections, imperatives, function words

\section{P2.1 Functional affixes and particles}

$\mathbf{a}_{2}$ nonsingular default aspect marker $\sim \mathrm{i}$

$\mathbf{a} \overline{\mathbf{e}}_{2}$ anaphoric marker, referring to previously mentioned place or topic, there, about (it) long hem, long ples ia (wan samting o ples we i bin tokbaot finis)

do- leaf of; derivational prefix which occurs both on nouns referring to plants, to specify a leaf of that plant, and also with a limited use to produce nouns referring to useful products made with leaves, such as a fan (dérivriv) or broom (döwurwur) lif blong (wan samting), wan maka we i talemaot se lif blong wan tri o plant o wan samting we i mekem long lif, olsem fan (dêrivriv) o brum (döwurwur) (Allomorphs: da-, de-, dē-, dë-, dō-, dö-)

go ${ }_{2}$ imperfective aspect marker $\sim$ maka we $\mathrm{i}$ go wetem veb we i talemaot se aksen i tek ples long fiuja o i refe 
long wan situesen we i stap olsem nomo (Allomorphs: ga, ge, gē, gë, gi, gō, gö)

goto negative particle, not $\sim$ no (Allomorphs: gata, gete, gētē, gëtë, giti, gōtō, götö)

$\mathbf{i}_{3}$ second person singular default aspect marker wod we i folem nēk 'yu', bifo long veb long sentens

kara just, of an event that has happened very recently or will happen very shortly after an upcoming event $\sim$ jas

$\mathbf{k e}_{2}$ emphatic particle $\sim$ we, tumas

kere dehortative marker; don't no; wod we i go bifo long veb long sentens, taem yu talemaot long wan man se bae i no mekem wan samting mas must $~$ mas

mawi dehortative; don't no; yusum blong talemaot se no mekem wan samting

mēsi emphatic marker, premodifying nouns, indicating that the subject has the characteristic indicated to a large degree $\sim$ tumas

$\min _{2}$ (abbrev. mi) high probability modality bae

mito future negative proclitic $\sim$ bae $i$ no; wod we i go bifo long veb we i talemaot se aksen bae i no tekples (Allomorphs: mita, mite, mitē, mitë, miti, mitō, mitö)

mo perfect aspect marker bin (Allomorphs: ma, me, mē, më, mi, mō, mö)

mönö (fr.var. mēnē) a bit smol

na first person singular default aspect marker mi (Allomorphs: nana)

ni (fr.var. nini) third person singular nonspecific aspect marker $\sim \mathrm{i}$

nitog prohibitive mood particle, dehortative marker; don't no; wod we $\mathrm{i}$ go bifo long veb long sentens, taem yu talemaot long wan man se bae i no mekem wan samting ren emphatic marker; right, absolutely, totally, definitely tumas, tru, stret; i makem strong toktok we yu talemaot

ri second person non-singular imperative marker yusum taem yu talem wan grup blong mekem wan samting

tabaē (abbrev. taē) of it, for it, anaphoric form blong hem, toktok we $\mathrm{i}$ gobak long narafala toktok we yu talem finis

ten $_{1}$ yet $\sim$ yet

ten $_{2}$ connative particle, try $\sim$ traem

terè (fr.var. tere) plural marker, occuring before common nouns ol, olgeta

ti ${ }_{1}$ eventive aspect marker

to ${ }_{2}$ progressive aspect marker, indicates an event that is in progress stap, go go, yusum taem yu tokbaot wan aksen we i stap gohed

towo immediate progressive aspect marker, marks an event currently in progress $\sim$ go go, yusum blong tokbaot wan samting we i stap hapen nao ia nomo (Allomorphs: tawa, tewe, tēwē, tëwë, tōwō, töwö)

va- causative prefix $\sim$ maka we $\mathrm{i}$ go long fored blong veb we i minim se mekem

$\operatorname{van}_{1} \mathbf{1} \cdot$ go (unmarked for direction) go $\mathbf{2}$ - on and on, postverbal particle indicating continuous aspect, continuation of an activity $~$ go go

ver collective subject, preverbal marker that indicates either that the subjects are performing the action of the verb collectively or that the action is reciprocal tugeta

vēti (fr.var. viti) still yet

vitia already $\sim$ finis

wo ${ }_{3}$ intensifying particle; absolutely, totally tumas, we

wo- noun categorisation prefix, used with separate functions: before male names; in plant names, in 
reference to the fruit or the tree; and in the formation of new nouns maka we i go long fran blong nem blong wan man, long nem blong tri o frut blong tri mo long wan niufala wod we yu krietem (Allomorphs: wa-, we-, wē-, wë-, wō-, wö-)

wun $_{2}$ high probability modality bae

\section{P2.2 Interjections}

aaōō expression of surprise, wow, gee $\sim$ awo

ake ow! expression used to indicate that you are hurt awo! toktok we i talemaot se yu kasem kil

ale $\overline{\mathbf{e}}_{2}$ ok, alright ale

aqa expression of surprise, disbelief, horror; gee, gosh awo, toktok blong singaot blong talem se yu sapraes long wan samting

auw gee! awo!

awi argh! awe!

awo $1 \cdot$ general interjection, used to express positive emotion, wow! woah! awo! 2 •general interjection, used to express negative emotion, hey! ow! awo!

dom great, word used by and with deaf people, from Bislama 'top' top, long lanwis blong ol def we i kamaot long 'top'

e'e yes $\sim$ yes

ei hey ei

i ow! awo!

ii hey! ei!

io yes $\sim$ yes

$\mathbf{k e}_{1}$ yes $\sim$ yes

kērēt ${ }_{1}$ yeah right! Interjection used teasingly to indicate that you know that what you or another interlocutor said is an exaggeration or inaccurate ei no!

kēti (fr.var. kiti) $\mathbf{1} \cdot$ wait, hold on $\sim$ wet, wet smol $\mathbf{2} \cdot$ short time $\sim$ sot taem

madagese (abbrev. medese) what's happening? what's going on? olsem wanem? mamarseg (abbrev. marseg) 1 - pity, feel sorry (for) $\sim$ sori (long) $\mathbf{2}$ • unfortunate, pitiful $\sim$ sori $\mathbf{3} \cdot$ sorry $\sim$ sori

odian̄ (abbrev. dian̄) 1 • no nogat 2 - negative nonverbal predicate, be not $\sim$ nogat

oo oh oo

$\overline{\mathbf{o}} \overline{\mathbf{o}} \mathbf{\text { no}}$; interjection used as negative response to a question, or to indicate a negative attitude to a proposition nogat

qaēl hey! awo!

qate $_{3}$ peekaboo! Interjection used in playing game of surprise with small children

timiak avē $1 \cdot$ how olsem wanem $2 \cdot$ what's going on? olsem wanem? varian thanks $\sim$ tangkyu

varwöt serves you right $\sim \mathrm{i}$ gud ia (talemaot long wan man taem wan nogud samting i hapen long hem be yu ting se i stret from wanem we hem i bin mekem)

wèsi dunno, an interjection indicating that the speaker does not know what is being enquired about $\sim$ mi no save

\section{P2.3 Conjunctions}

$\mathbf{a l e}_{1}$ so, then, conjunction used to link coordinate clauses $\sim$ ale

ba but be

dēmē plus, used to conjoin numerals, thousands and hundreds and tens and units wod we $\mathrm{i}$ joenem tugeta tu pat blong hae namba, olsem tu handred mo twenti

$\mathbf{e}_{1}$ then, so; conjunction used to join coordinate clauses $~$ ale

in̄ko then $\sim$ nao

qēt ${ }_{2}$ then, clause initial consecutive marker finis, afta

$\mathbf{s i}_{2}$ or $\sim 0$

söwlē (abbrev. söw) then, so ale

wo and; conjunction that can join phrases and clauses $\sim$ mo 


\section{P2.4 Subordinators}

a⿳亠̄̄o den before, introduces temporal adverbial clause $\sim$ bifo long

den $_{2}$ lest, in case, introduces adversative clause $\sim$ nogud

la masawre when, introduces temporal adverbial clause $\sim$ taem

$\mathbf{s i}_{1}$ if, introduces conditional clause sapos

so relativiser, that $\sim$ ia

sur $_{2}$ because, introduces adverbial clause of reason $\sim$ from

tabo in order to, so that, introduces adverbial purposive clause $\sim$ blong

talo ${ }_{2}$ in order to, so that, introduces adverbial purposive clause $\sim$ blong

timiak $_{2}$ (abbrev. tiak) $\mathbf{1} \cdot$ like, introduces adverbial clause of manner $\sim$ olsem $\mathbf{2} \cdot$ like olsem

vita $(\text { abbrev. ta })_{1}$ that, complementiser introducing complement clause $\sim$ se

wōl ${ }_{3}$ because, introduces clause of reason $\sim$ from

\section{P2.5 Articles}

$\mathbf{a}_{1}$ locative, to, at, marking absolute location nouns long, maka we i go wetem ol nem blong ples

$\mathbf{i}_{2}$ personal article denoting nouns in personal noun class maka we $\mathrm{i}$ go wetem naon we i talemaot nem blong man o famle

ira plural personal article ol; wod we $i$ go bifo long naon long sentens

lo ${ }_{2}$ locative preposition, to, at, on, marking common nouns $\sim$ long

na the, a, article denoting noun that is in possessive construction $\sim$ wan, maka blong naon

o the, a, article denoting noun in class of common nouns wan, maka blong ol naon

ra plural marker denoting personal nouns ol, maka we i go wetem nem blong man we i soemaot se i gat plante man long grup

\section{P2.6 Discourse markers}

$\mathbf{k} \overline{\mathbf{e}}_{2}$ emphatic particle $\sim$ tumas

mina discourse particle $\sim$ we

timiak $_{2}$ (abbrev. tiak) $\mathbf{1} \cdot$ like, introduces adverbial clause of manner $\sim$ olsem

$\mathbf{2} \cdot$ like olsem

wana discourse particle $\sim$ we

wōl discourse particle used when asking a question, indicating that you recognise that you are seeking information that you should already know, but want to be reminded wod we yu ademap long wan kwestin, blong soemaot se yu sud save ansa blong kwestin, be yu askem bakegen

P3 Negations, assertions, possibility

odian̄ (abbrev. dian̄) 1 • no nogat 2 - negative nonverbal predicate, be not nogat

$\overline{\mathbf{o}} \overline{\mathbf{o}} \mathbf{\overline { n }}$ no; interjection used as negative response to a question, or to indicate a negative attitude to a proposition nogat

rivteg 1 - near, close by klosap $\mathbf{2} \cdot$ near to, close to $\sim$ klosap long $\mathbf{3} \bullet$ nearly, soon klosap

wēsi dunno, an interjection indicating that the speaker does not know what is being enquired about $\sim$ mi no save wun probably, I think ating

wun $_{2}$ high probability modality $\sim$ bae

P4 Non-verbal communication

bōk book buk

kilmat blink eyes to make a sign to a woman that you want her $\sim$ mekem ae long woman blong talemaot long hem se yu wantem hem

n̄ēnēs $1 \cdot$ smile, showing your teeth smael, soem tut blong yu $\mathbf{2} \cdot$ show teeth soemaot tut

qet möwu nod head, show agreement $\sim$ sakem hed se i oraet 
$\mathbf{r e ̄ v}$, write raetem

vasōgō read ridim

vikas communicate in sign language

toktok wetem han

P5 Sounds

aw shout, cry out singaot

dēn beat, tap lightly, bang, beating just to make a noise, rather than to make music or signal to people kilim (bambu, wud) blong mekem noes nomo qōrōtōt 1 - make a lot of noise, be noisy $\sim$ mekem tumas noes $\mathbf{2} \cdot$ loud sounds, too much noise $\sim$ tumas noes

rarö noise noes

tarōñ be quiet, be calm, be peaceful stap kwaet

tōr $\mathbf{r}_{1}$ bark singaot (dog)

töqöl boom, bang, make a loud booming noise mekem bigfala noes olsem saon blong tanda

\section{Q Social interaction, relationships and behaviour}

\section{QO General}

metwu personality, behaviour, manner, habit fasin

metwōn her/his/its personality fasin blong hem

metwuk my personality fasin blong mi

qetgengen feast, planned celebratory feast lafet, wan kakae we yumi ekspektem blong holem, plan blong mekem kakae

sal $_{1} \mathbf{1} \cdot$ message $\sim$ mesej $\mathbf{2} \cdot$ send message $\sim$ sendem mesej

tōrtōr 1 - preach, give important speech, as in at wedding givim hevi toktok $\mathbf{2} \cdot$ speech $\sim$ strong toktok

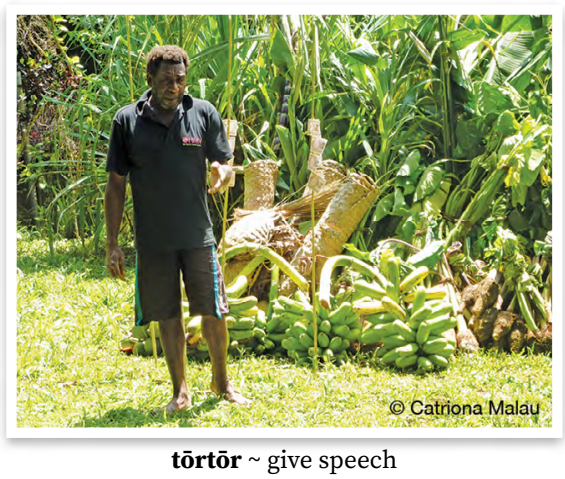

Q1 Fighting

dar $\mathbf{1} \cdot$ blood $\sim$ blad $\mathbf{2} \cdot$ bleed $\sim($ blad i) ron daran her/his/its blood blad blong hem

dere qō pig's blood blad blong pig dërëk my blood blad blong mi

lā̄ bash, hit, beat strongly kilim strong

mëmës hurt, be sore, ache soa

rēs 1 - fight, wrestle, struggle $\sim$ faet

2 - struggle, fight an urge $\sim$ traem blong winim

tavalalē enemy badfren, enemi

tēq, shoot (with gun) sutum (wetem masket)

tēqatēq $1 \cdot$ hunt with bow and arrow in the bush (birds and flying fox) hant wetem bonaro long bus (blong sutum pijin o flaengfokis) $\mathbf{2}$ • gun masket

timiatēq gun $\sim$ masket

töwös hit kilim

tut ${ }_{1}$ punch $\sim$ faetem

vagal war, large scale fighting wo, bigfala faet 
vēn shoot (with bow and arrow or spear) sutum (wetem bonaro o spia)

vēnvēn go shooting go blong sut

wos $_{1} \mathbf{1}$ - bash, slap, pound; hammer, bash (nuts) to crack open $\sim$ hamarem $\mathbf{2}$ - build bildim

\section{Q2 Verbal quarrelling}

dörug trick, play a trick on, deceive trikim, giaman long

gial $1 \cdot$ lie, tell untruth $\sim$ giaman $2 \cdot$ lie, tell untruth to $\sim$ giaman long $3 \cdot$ trick, pretend to $\sim$ giaman long gilgial lie $\sim$ giaman

kes argue, row with $\sim$ rao

liseg disobey, argue with disobei, no folem tingting blong

vergöl argue, row rao

verliseg argue $\sim$ rao

Q3 Making peace, maintaining social harmony

birin̄ help givhan long, halpem

bulsal $1 \cdot$ friend, mate, can be sexual partner or platonic friend $\sim$ fren $2 \cdot$ friend, used as an address term fren $3 \cdot$ be friends, become friends $\sim$ fren $\mathbf{4}$ - become sexual partners fren (olsem gelfren mo boefren)

döm mav 1 • respect $\sim$ ting hevi, respek

$2 \cdot$ respect $\sim$ respek

qet möwu nod head, show agreement $\sim$ sakem hed se i oraet

tamat peace $\sim$ pis

Q4 Games, entertainment, laughter, joking

bēm naw surf, go surfing karem wef long solwota

bor laugh laf

borbor laughter $\sim$ laf

borseg laugh at laf long

kikbol play soccer plei futbol

or play plei oror 1 - play pleplei $2 \cdot$ game $\sim$ pleplei

vërlē (fr.var. verlē) compete, race kompit, resis

\section{Q5 Being affected}

birin̄ help givhan long, halpem

datek $\mathbf{1}$ •look after lukaotem $\mathbf{2}$ • have knowledge of, possess and use a certain skill or knowledge $\sim$ gat save long wan samting, holem wan save blong yusum

ēlgōr 1 • look after, care for lukaotem 2 - watch out, be careful lukaot

gasēg share out, separate, divide seraotem

mamarseg (abbrev. marseg) 1 - pity, feel sorry (for) sori (long) $\mathbf{2}$ • unfortunate, pitiful $\sim$ sori $3 \cdot$ sorry $\sim$ sori

ōligi invite invaetem

Q6 Permission and prohibition

baēr ask (someone) for something, ask (something) from someone askem wan samting long wan man

$\mathbf{l} \overline{\mathbf{e}}_{2}$ law loa

liseg disobey, argue with disobei, no folem tingting blong

qil order, tell someone that they must do something talem long wan man se i mas mekem wan samting

tiargōr prevent, stop someone from doing something stopem

Q7 Community

bultiwial unity yuniti

sal 1 - message $\sim$ mesej $2 \cdot$ send message $\sim$ sendem mesej

vug ${ }_{2}$ have meeting $\sim$ miting vugvug meeting miting 


\section{$R$ Religion, ceremony, law and the supernatural}

\section{RO General}

dun $1 \cdot$ true, be true, real $\sim \operatorname{tru} 2 \cdot$ sure, tell truth $\sim$ sua, tru $\mathbf{3} \cdot$ truth $\sim$ tru

löglē religion, church $\sim$ jos, skul

nōmtuv $\mathbf{1} \cdot$ believe biliv $2 \cdot$ belief bilif

tatar $\mathbf{1} \cdot$ pray $\sim$ prea $2 \cdot$ prayer $\sim$ prea

R1 Law, sacred places, legends

bōgō man who has not learned the traditional ways in the men's house to gain rank man we hem i no bin go long nakamal blong lanem stret rod blong kastom

Dōl name of mythical creation figure, enemy of the main creation figure Qet nem blong man long kastom storian

$\mathbf{e v}_{1} \mathbf{1} \cdot$ fire $\sim$ faea $\mathbf{2} \cdot$ hell $\sim$ hel

gōrōn̄ holy, sacred, spiritually meaningful tabu

kētkēt 1 • in air, up high above ground $\sim$ antap, long ea, i no long graon $\mathbf{2}$ - heaven $\sim$ heven

$\mathbf{l} \overline{\mathbf{e}}_{2}$ law $~ 1$ oa

maranag chief $\sim$ jif

meter woman of high rank who has studied to learn the true traditional way of life woman we hem i bin go long nakamal blong lanem stret rod blong kastom

miar veser call someone father when they also call you father (of man) singaotem papa long man we hem i singaotem papa long yu

qeren̄ ōlōl cave, hole in reef or pool that has special significance, where people go to pray, give money and ask the spirits for something that you want, or to appease and ask forgiveness from the spirits if you have done something wrong against them tabu hol long kef, long rif o long wota we ol man ol i go long hem blong prea long ol speret from wan samting o talem sori from wan samting we yu bin mekem

sar ${ }_{1}$ ceremonial ground $\sim$ nasara

seretimiat area associated with the spirits of the dead, on the top of a hill nasara blong ol devel. Hem $i$ wan ples antap long hil, wan ples we ol spirit ol i go stap long hem

serevugvug meeting place for spirits of the dead, underneath a banyan tree ples we ol devel ol i mit long hem. Hem i wan ples andanit long wan nambangga we i klin we i klin sölö put taboo, place marker to indicate restriction, usually a cycad leaf is placed to indicate, for example, that people should not fish or should not take the fruit from a tree putum namele lif, olsem tabu blong soemaot se ol man ol i no sud mekem wan samting, olsem tekem kakae long wan wud

sösölö a cycad leaf placed to indicate a restriction on use of plant or area lif namele we yu putum blong makem tabu

tövusm̄ēl chief who has gained rank in traditional way by kiling pig stret kastom jif we hem i bin kilim pig

wèrēsōr place where the spirits of the dead go to rest when they are tired, a place on a point or hill wan ples we ol devel ol i go spel long hem, sapos ol i wokabaot go go ol i wantem spel. Hem i wan ples long wan poen o hil 
wöwut man of high rank who has studied the traditional rules and way of life in the men's house $\sim$ man we hem $\mathrm{i}$ bin go long nakamal blong lanem stret rod blong kastom

\section{$R 2$ Ceremony and rituals}

\section{R2.1 Ceremonial objects}

ganar rope made from cottonwood which one hangs around the neck as a sign that one has given up a particular type of food out of respect when a close relative has died $\sim$ rop we man i hangem long nek blong hem blong soemaot se hem i givap wan kaen kakae taem mama o papa blong hem i ded

gon ganar tie a rope around ones neck as a symbol to indicate that you are mourning the death of ones father or mother, the rope also indicates that one is giving up a particular food for the mourning period taem we man i fasem rop long nek blong hem blong soemaot se hem i givap wan kaen kakae taem mama o papa blong hem i ded

möökölagē food and presents for the house given with bride price $\sim \mathrm{ol}$ samting we ol i givim wetem braed praes olsem kakae mo ol samting blong haos

timiatwos traditional wooden upright drum tamtam

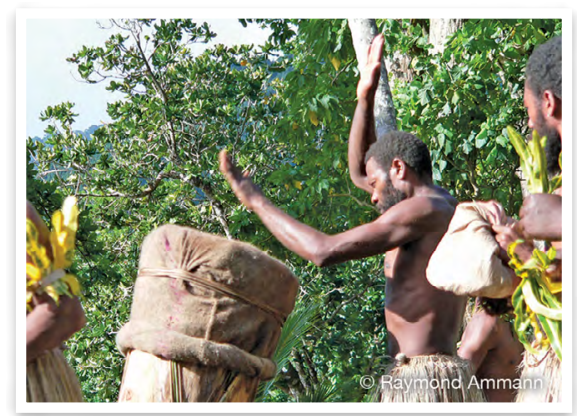

timiatwos $\sim$ wooden drum tōw ${ }_{4}$ (fr.var. tōw mölum) triton trumpet, conch shell pupu Charonia tritonis

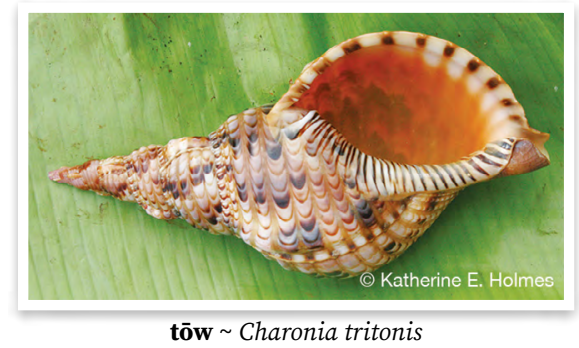

wōkōr slitgong that is made from bamboo or hollowed out wood tamtam we ol i mekem long bambu o wud

\section{R2.2 Ceremonies and rituals}

da lagē pay bride price pem woman genqinimate last feast that is made to celebrate someone's death, 1,000 days after the death $\sim$ kakae las dei long wan taosen dei blong ded man. Hem i kakae blong finisim tingbaot man we i ded mo blong stat blong fogetem. Hem i no dei blong sore, i dei blong glad. Hem i talem se i naf blong tingbaot, nao ol i save fogetem gëvgëv perform ceremony when someone has killed another person, to pay the person's family for their life $\sim$ pem laef blong wan man we yu bin kilim

gon wōmōotō make an agreement that two small children will marry when they come of age. The boy's family gives money and coconuts to the girl's father. Two germinating coconuts are tied together and must be planted together as a symbol of the bond mekem agrimen se bae tufala pikinini i mared taem tufala pikinini i smol nomo. Famle blong boe ol i fasem tu kokonas tugeta mo givim long papa blong gel wetem mane. Ol i mas planem tu kokonas 
tugeta mo hem i wan saen se bae tufala i mared. Hem i wan strong agrimen we bae ol i no save brekem gōrga cut the mourning rope from the neck of a man who has fasted during period of mourning for father or mother. The ceremony is performed in the morning of the 999th day after person has died. The same family who tied the rope around the person's neck must cut the rope, then they give the person the food that he has not eaten during the mourning period, and he must pay them. seremoni we ol i mekem long eli moning long naen handred naenti naen dei blong wan ded man. $\mathrm{Ol}$ man we ol i bin hangem rop long man we hem i fas long kakae, ol i kam katem rop. Afta ol i givim kakae long man we hem i no kakae kakae ia mo man ia i mas pem hem.

gösuv miar bathe baby in a traditional ceremony that occurs 5-10 days after the baby is born, the aunts of the child bathe the child and the father pays the aunts for this contribution $\sim$ faef o ten dei afta fes pikinini i bon, ol sista blong papa ol i kam wasem pikinini mo flasem hem mo afta papa i mas pem olgeta

kōl perform grade-taking ceremony, that a man performs in order to increase in rank as a chief, which involves killing of pigs kilim pig long seremoni blong leftemap rang

kōlkōl grade-taking ceremony, ceremony that a man performs in order to increase in rank as a chief $\sim$ seremoni we man o woman i save mekem blong tekem rang. Woman i mekem long haos, man i mekem long nakamal

leleverser ceremony in which the family of a man who has died give money to other members of the family wan seremoni we ol famle blong wan man we hem i ded ol i givim mane long olgeta insaed long famle

matē $\mathbf{1} \cdot$ death $\sim \operatorname{ded} \mathbf{2} \cdot$ funeral, death ceremony $\sim$ seremoni blong ded matian her/his/its death $\sim$ ded blong hem

matiēk my death ded blong mi

miarten noises that are made with bamboo flutes and other things when people are making a vōnōmōōo ceremony ol noes we ol man ol i mekem wetem flut o wanem, taem ol i mekem vōnōin̄ōtō

qalēg gōr make an agreement between the parents that a particular girl or woman will be married to a man blokem, putum tabu long wan gel mo givim mane se bae tufala i mared qin̄imatē measurement of days since someone's death $\sim$ dei blong ded we yu kaontem kasem wan taosen dei

sersöm return some of bride price if a couple divorce, the woman's family must return money to the man's family who paid the bride price givim bak mane sapos mared i finis mo man mo woman i divos, famle blong woman i mas mekem long famle blong man we ol i bin pem woman ia

siganar remove rope from the neck of a man who has not met the goal of giving up a certain food for 1,000 days during the mourning period after the death of a close relation tekemaot rop (ganar) long wan man we hem i no save lego kakae we hem i bin talem se bae hem i no kakae kasem wan taosen dei blong wan man long famle blong hem i ded

sōq perform grade-taking ceremony, by killing of pig kilim pig long seremoni blong tekem rang

tuleg act of children of a dead man making payment to their father's family to claim their right to his 
land and property taem wan man i ded, ol pikinini blong ded man ol i mas givim mane long famle blong papa blong pemaot graon mo ol propeti long ol famle blong mekem se i graon blong olgeta nao

veltiwial time when the family of a couple who are to be married come together in order to settle the couple together long taem blong mared ol famle blong man mo woman i kam tugeta blong putum tugeta boe mo gel

vōnō̄mōōō tradition that is performed in the afternoon of the fourth day after someone has died, in which the heads of the families of the man who has died do such things as remove the dead man's house or cut wood in his garden. The children of the dead man must then pay the people who have done this $\sim$ long aftenun long namba fo dei blong wan man i ded, ol man (lida blong olgeta hem i famle blong man we hem i ded) ol i kam katem wud long garen o tekemaot haos blong ded man mo ol samting olsem. Afta pikinini blong ded man i mas givim mane long ol man we ol i mekem

völöt traditional practice in which when the first child of a couple is born, the family of the mother come and try to throw stones at the father of the child and his family taem fes bon pikinini i bon, famle blong mama ol i traem stonem papa blong pikinini wetem ol famle

vusarōr kill pig in order to release the spirit of someone who has died. The dead person is quiet but the pig squeals to represent the person crying as their spirit is released. $\sim$ kilim pig blong lego spirit blong man we i ded. Ded man i kwaet be pig i singaot blong representem ded man i singaot mo hem i lego spirit. vusveslivmat kill a pig or chicken to close the eyes of someone who has died, a ceremony performed by one of the children of person who has died kilim pig o faol blong klosem ae blong man we i ded, wan pikinini blong man we i ded i mekem

wölqareñi make payment to the people who dug a dead person's grave pem ol man we ol i digim gref blong ded man

\section{R3 Death and mourning}

matē $\mathbf{1} \cdot$ death $\sim \operatorname{ded} \mathbf{2} \cdot$ funeral, death ceremony $\sim$ seremoni blong ded matian her/his/its death $\sim$ ded blong hem

matiēk my death ded blong mi

miat die, be dead $\sim$ ded

miarten noises that are made with bamboo flutes and other things when people are making a vōnōmōto ceremony ol noes we ol man ol i mekem wetem flut o wanem, taem ol i mekem vōnōinōtō

onvegtëm lay in the same house with the body of someone who has died after sunset, until the next day when they can remove the body in daylight $\sim$ sapos wan man hem i ded long sapa, ol i mas slip wetem hem kasem neks dei

qin̄imatē measurement of days since someone's death, counted up until 1,000 days dei blong ded we yu kaontem kasem wan taosen dei

siganar remove rope from the neck of a man who has not met the goal of giving up a certain food for 1,000 days during the mourning period after the death of a close relation tekemaot rop (ganar) long wan man we hem i no save lego kakae we hem i bin talem se bae hem i no kakae kasem wan taosen dei blong wan man long famle blong hem i ded 
tövun (fr.var. tuvun) $\mathbf{1}$ bury berem $\mathbf{2}$ - fill in (hole), cover over something in hole berem

turgēn $\mathbf{1} \cdot$ body $\sim$ bodi $\mathbf{2} \cdot$ trunk of tree $\sim$ stamba blong wud

vōnōmōōlō tradition that is performed in the afternoon of the fourth day after someone has died, in which the heads of the families of the man who has died do such things as remove the dead man's house or cut wood in his garden. The children of the dead man must then pay the people who have done this long aftenun long namba fo dei blong wan man i ded, ol man (lida blong olgeta hem i famle blong man we hem i ded) ol i kam katem wud long garen o tekemaot haos blong ded man mo ol samting olsem. Afta pikinini blong ded man i mas givim mane long ol man we ol i mekem

vusarōr kill pig in order to release the spirit of someone who has died. The dead person is quiet but the pig squeals to represent the person crying as their spirit is released. $\sim$ kilim pig blong lego spirit blong man we i ded. Ded man i kwaet be pig i singaot blong representem ded man i singaot mo hem i lego spirit.

vusveslivmat kill a pig or chicken to close the eyes of someone who has died, a ceremony performed by one of the children of person who has died kilim pig o faol blong klosem ae blong man we i ded, wan pikinini blong man we i ded i mekem

wölqareñi make payment to the people who dug a dead person's grave pem ol man we ol i digim gref blong ded man
R4 Taboos, strictures and secret knowledge

$\operatorname{man}_{1} \mathbf{1} \cdot$ intoxicate, stun, poison, as in kava, alcohol or poison making you feel drunk or delirious kilim, mekem i drong, olsem man $\mathrm{i}$ posenem fis o kava $\mathrm{i}$ kilim man $2 \cdot$ magic, words used when performing magic or to support use of traditional healing and other purposes majik, toktok blong talemaot long taem blong yusum kastom meresin mo sam narafala samting

maw $_{2}$ secret $\sim$ wan save we bae yu yusum be yu no save lego

$\overline{\mathbf{o}} \mathbf{l} \mathbf{o} \mathbf{l}_{2}$ traditional secret prayer made at a sacred place to ask for something desired kastom prea long tabu ples blong askem wan samting

salgōr sacred and restricted act or thing samting we i tabu

sian gōgōn name that one uses to refer to or address someone who has the same name as an in-law whose name you are unable to say, due to cultural restrictions of the relationship nem we yu yusum blong talemaot wan man o woman we hem i gat semak nem olsem wan tawian o palika blong yu, from we nem i semak, i tabu blong singaotem nem

vēl ${ }_{2}$ use magic to kill a person yusum majik blong kilim wan man i ded

\section{R5 Healing and medicine}

sus 1 - poke, prod, pierce stikim 2 • point (with finger) $\sim$ poen (wetem fingga) $3 \cdot$ inject, give injection to stikim (wetem stik meresin)

tenge leaf remedy, plant used for traditional medicine, fertilising crops, aiding fishing and other traditional remedies and purposes 
lif meresin o lif we ol i yusum long saed blong kastom olsem blong fis o long garen

\section{$R 6$ Singing and dancing}

ber $_{1} \mathbf{1} \cdot$ grass skirt, skirt made from beach pandanus $\sim$ grasket $\mathbf{2}$-wear grass skirt $~$ havem grasket

bō 1 - length of bamboo used for carrying water bambu blong fulumap wota $\mathbf{2}$ - length of bamboo used for making beat in dance bambu blong kilim long wud long taem blong danis

diat $_{2}$ make a mistake and not reach the end when performing a dance mestem mo no kasem stret en blong danis

elnetiti style of traditional dance that is performed at the ceremony marking 1,000 days since someone's death wan danis we ol man ol i danis long wan taosen dei blong wan ded man. Ol man ol i danis blong soemaot se ol i glad mo ol i stat blong fogetem

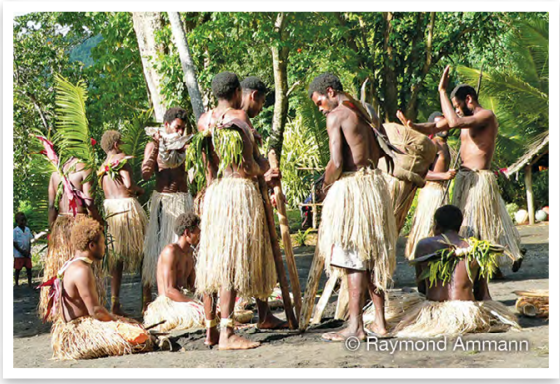

elnetiti style of dance

ës 2 song singsing

lak dance $\sim$ danis

laklak dance $\sim$ danis

lalēbur thick slab of wood that is placed over hole in ground and used to make the sound and rhythm, especially for elnetiti dance $\sim$ bigfala pis wud we ol i putum ova long wan hol long graon mo ol i kilim wetem wud blong mekem gudfala saon blong danis, speseli blong elñetiti

liañ style of traditional dance $\sim$ kaen kastom danis

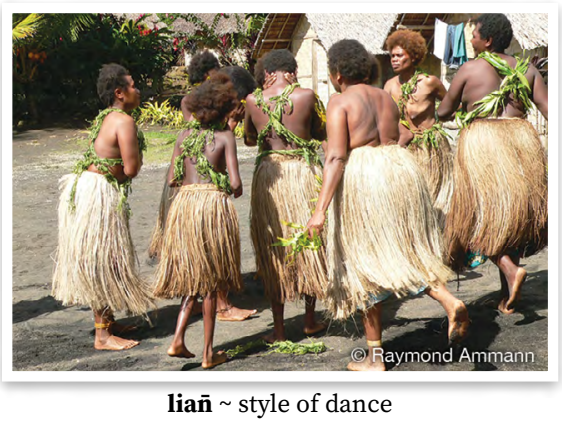

me 2 - name of a traditional dance nem blong wan kaen kastom danis

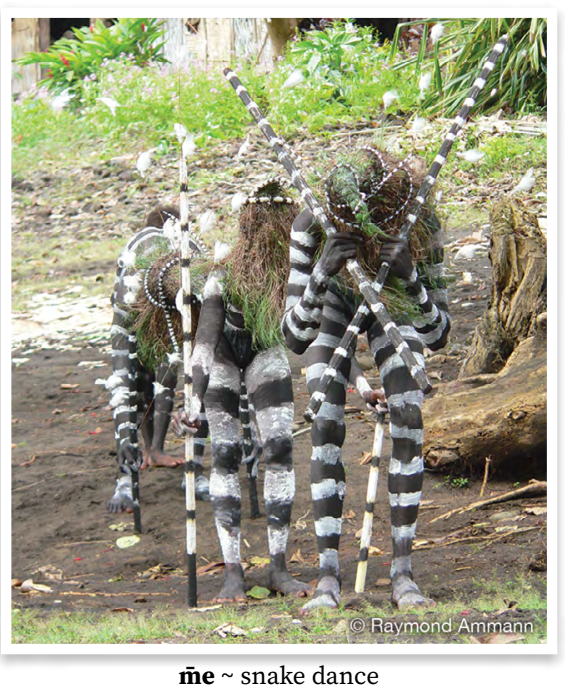

rësrës deñe style of dance that is made at a ceremony held five days after someone's death, when their spirit leaves the earth to go to the place of the spirits (lisōr) wan kaen danis we ol i mekem long faef dei blong ded blong wan man, taem spirit blong hem i go long ples blong ol ded (lisōr) 
rëw sing singim, singsing

sēsēlit water music wota miusik

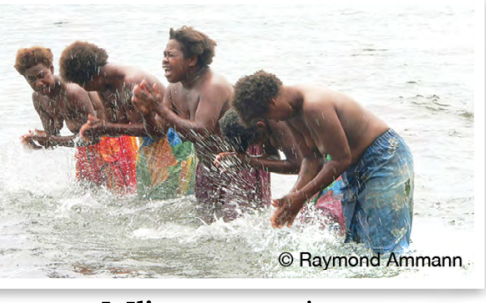

sēsēlit water music

siwia kind of public dance kaen pablik danis

sur ${ }_{4}$ sing singim

timiat $_{2}$ headdress worn by men for particular dances hedres we ol man i werem long taem blong danis

timiatwos traditional wooden upright drum tamtam

tōw ${ }_{5}$ compose (song) komposem (singsing)

veleg beat (usually bamboo or wood) with one stick in each hand to make music or dance beat kilim tamtam, bambu blong mekem miusik, o man i danis long hem

weveveleg sticks used for beating slitgong wud we ol i yusum blong kilim tamtam

wōkōr slitgong that is made from bamboo or hollowed out wood tamtam we ol i mekem long bambu o wud

wöduñdun long, thick stick that is used for beating on wooden slab that is placed over hole in ground to make beat, especially for elnetiti dance longfala wud we ol i yusum blong kilim flat pis wud long graon long taem blong elñetiti danis, we $\mathrm{i}$ mekem bit blong danis
R7 Feasting

gis salmiat make preparations for a feast priper blong mekem bigfala kakae, speseli long wan taosen dei blong wan ded man

qetgengen feast, planned celebratory feast lafet, wan kakae we yumi ekspektem blong holem, plan blong mekem kakae

\section{R8 Christianity}

\section{gengenur $\sin \sim \sin$}

gōrōn holy, sacred, spiritually meaningful tabu

gösuv rōn̄ baptise baptaes

gövur house, generic name for building haos gövur gōrōn̄ church jos gövur tatar church jos

leg marry (in church), be married mared (long jos)

legleg marriage ceremony (in church) mared (long jos)

lōlōqōr $\mathbf{1}$ • forgetful save fogetem tumas samting $\mathbf{2} \cdot$ heathen, lacking Christian enlightenment $\sim$ taem $\mathrm{O}$ man blong tudak

Mam 1 1 Dad $\sim$ Papa $2 \cdot$ God $\sim$ Papa God tatar $1 \cdot$ pray $\sim$ prea $2 \cdot$ prayer $\sim$ prea vawē $\mathbf{1} \cdot$ bless blesem $\mathbf{2} \cdot$ blessing blesing 


\section{S Hunting, fishing, farming}

\section{S1 Hunting}

bien $\mathbf{1} \cdot$ feed $\sim$ fidim $\mathbf{2}$ put bait in trap $\sim$ putum bet long basket naora

gatitieg bird or pig trap made from rope $\sim$ trap blong pijin o pig

san 1 - pull with quick movement, as in pulling in a fish pulum, jokem 2 - kind of trap for catching chickens and birds on the ground. A rope is tied to a piece of wood and a loop made in the rope, then food is scattered around on the ground. Then the rope is pulled tightly when a bird walks inside the loop wan kaen trap blong kasem faol o pijin long graon we yu fasem rop long wud long graon, putum kakae raon long rop mo jokem kwiktaem taem pijin i stanap insaed long rop

san via try to pull in a fish but it gets away pulum fis be yu mestem

san qal pull fish successfully pulum fis

sēsēdig method of trapping birds wei blong kasem pijin wetem trap we yu fasem rop long brans blong tri mo yusum frut blong atraktem pijin ga sēsēdig rope for trapping birds rop blong trap blong pijin

tēqatēq $1 \cdot$ hunt with bow and arrow in the bush (birds and flying fox) hant wetem bonaro long bus (blong sutum pijin o flaengfokis) $\mathbf{2}$-gun masket

tieg lay trap putum trap

timiatēq gun $\sim$ masket

tit $\mathbf{1} \cdot$ split $\sim$ splitim $2 \cdot$ pull rope down quickly and sharply when trying to catch bird with a sēsēdig bird trap jokem string blong kasem pijin long sēsēdig tut ${ }_{2}$ hunt at night, using light to shine on prey, such as flying fox, coconut crab, crab, prawns mekem laet, olsem blong kasem krab, flaengfokis, naora long naet

vus bow bonaro

wètèq kind of arrow that has a blunt end so that it will bounce off a tree if the target is missed and not get stuck, used for shooting birds wan kaen aro we en blong hem i no sap blong hem i no save fas long wud taem yu sut wetem, i mas foldaon, ol i yusum blong sutum pijin

\section{S2 Fishing}

beret $_{1}$ try to shoot something (e.g. fish with bow and arrow, bird with shanghai or person with stone) but be unsure if it can be hit as it is far away or can't be seen properly traem sut (olsem fis wetem bonaro, pijin wetem lastik o stonem man we i stap long bus) be yu no sua se yu save kasem from maet i stap longwe tumas o yu no save luk gud

beberet training to shoot a target with a bow and arrow trening blong sut wetem bonaro

b $\overline{\mathbf{e}}_{2}$ bait hook putum bet long huk

gasalē right size place for setting net where the fish won't be able to get away stret ples blong putum net we ol fis bae ol i no save lus

giam $\mathbf{1} \cdot$ net $\sim$ net $\mathbf{2} \cdot$ net covering stomach $\sim$ net we i kavremap gat giam vus net with a handle $\sim$ kaen net wetem handel blong hem tē giam place net putum net go hook, fish hook huk blong fis kal pull in fishing line, pull up fish pulum string 
kar spear with four prongs and rubber $\sim$ spia we hem i gat raba blong hem meteër arrow made from wood of casuarina, with sharp point, used for shooting fish aro we ol i mekem long wud blong oktri, we i gat sap en blong hem mo ol i yusum blong sutum fis

qēsqēs fishing technique where one pounds hermit crabs so that they smell and then throws them in the sea to attract fish wan fasin blong kasem fis we yu kilim hed blong nakato blong mekem se i smel, mo afta yu sakem long solwota blong atraktem fis

qōrser kind of spear with several prongs on the end $\sim$ wan kaen spia we $\mathrm{i}$ gat plante poen long en blong hem

qōt dive (for) daeva (long)

qōtqōt go diving daeva

rērēv towline $\sim$ tolaen

ser $_{1}$ spear spia

so $_{3}$ gather, harvest palolo worm karem palolo, wom blong solwota

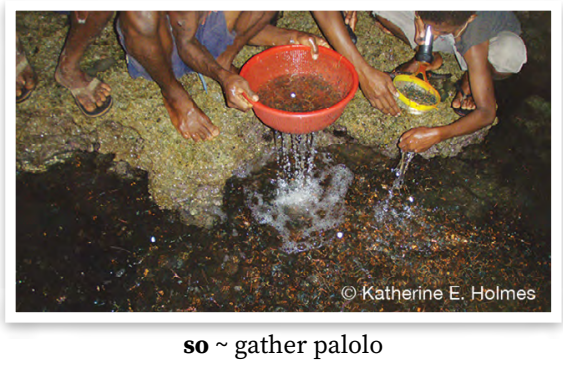

sōsōg fish, go fishing go huk

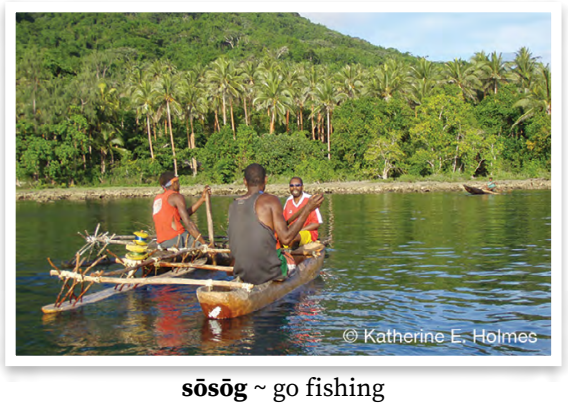

varwëw troll (fishing line) fasin blong fising long bot we yu lego string we i stap long rol

vetbōñ rope used for picking up a wōw fish trap from the bottom of the sea. It has a stone on the end that has a hole in it for tying the rope to it, and a special hook rop wetem ston mo huk long en blong hem blong pulum wōw net we i stap long solwota

vëkrës scale, remove scales from fish $\sim$ tekemaot skel blong fis

vidir (fr.var. vēdir) $\mathbf{1} \cdot$ remove midrib from sago palm leaf $\sim$ tekemaot bun blong lif natanggura 2 - shoot liaw fish sutum liaw fis

vovon̄on go fishing, looking for shellfish or other sea or freshwater creatures $\sim$ lukaotem mit long wota o solwota

vötuga reel, fishing reel wud blong rolem rop i stap long hem

vötuga sēsēdig reel for rope for catching birds wud blong rolem rop i stap long hem blong kasem ol pijin

vötuga sōsōsōg fishing reel wud blong rolem string blong fising $i$ stap long hem

vukrē scale skel blong fis

vunvun poison fish $\sim$ posenem fis vun viteg method of poisoning fish in deep sea $\sim$ fasin blong posenem fis long dip si

waraēl fishing bamboo pole $\sim$ bambu blong hukum fis

wēbē bait bet

$\mathbf{w o ̄ l o g}_{1} \mathbf{1} \cdot$ flexible wood for making trap wud blong bendem blong mekem trap $\mathbf{2} \cdot$ handle of a $w \bar{w} w$ trap $\sim$ handel blong fis trap wōw

wōw 1 kind of fish trap used in the deep sea, which is like a lobster pot but used only for catching fish wan kaen net trap we yu yusum long medel si. Yu putum bet insaed 
mo i gat wan hol antap be taem ol fis ol $\mathrm{i}$ go insaed ol i no save kamaot bakegen

tul wōw throw wōw fish trap into the sea $\sim$ draonem wow net long solwota wödön $\mathbf{1} \cdot$ method of baking in a stone oven, in which the stones are placed on the fire to heat, then when they are heated through and the fire has died down, the stones are removed, the food is placed on the bed of the oven, and the hot stones are placed on top of the food parcel wei blong bekem kakae we yu tekemaot ston, putum kakae long oven, afta putum hot ston antap long kakae $\mathbf{2} \cdot$ method for setting wöwöwör qēsaqēs fish trap in sea, or waga prawn trap in river, in which stones are placed on top and around the trap to prevent it from being carried away by the current. putum trap blong fis long solwota o trap blong naora long wota mo putum ston raonem hem blong taed i no save muvum

wöwöwör qēsaqēs kind of trap used close to the shore for catching small fish and particularly lobster kaen trap we yu yusum klosap long so blong kasem ol smol fis mo speseli naora

wutge mark spot at sea makem ples long solwota

\section{S3 Farming and propagation}

biriat garden where taro is planted in dry ground on hill $\sim$ drae garen taro antap long hil

bōak $\mathbf{1} \cdot \operatorname{mud} \sim \operatorname{sofmad} \mathbf{2} \cdot$ taro garden planted in mud $\sim$ garen taro we ol $\mathrm{i}$ planem long sofmad

dōw become overgrown (garden) bus i kavremap garen $\mathbf{e v}_{2}$ use digging stick to loosen taro, after pull out of ground yusum wud blong mekem graon i sofsof, mo pulumaot taro long graon

gil $1 \cdot$ dig, dig up food plants, etc. digim $2 \cdot$ digging stick stik blong digim graon $\mathbf{3}$ - Stick used for removing husk from coconut $\sim$ wud blong karemaot skin long kokonas

gōq make hole with digging stick to plant taro $\sim$ digim graon wetem wud blong mekem hol blong taro

kor make kindling, cut trees and branches which you have cut down into smaller pieces so that they will dry and you can burn them katkatem ol brans mo wud we yu bin katem blong livim i drae redi blong bonem

liaq irrigate $\sim$ putum wota i go insaed long garen taro

löñ $\mathbf{1}$. place leaf over fire in order to block and reduce the heat $\sim$ putum lif long faea fastaem blong blokem sapos i bigwan tumas 2 - block off water to change watercourse so it flows into taro paddy blokem wota blong mekem i go long garen taro

mat taro garden planted in running water or mud, where the water is never drained off, taro paddy garen taro long wota o sofmad we wota i stap long hem oltaem

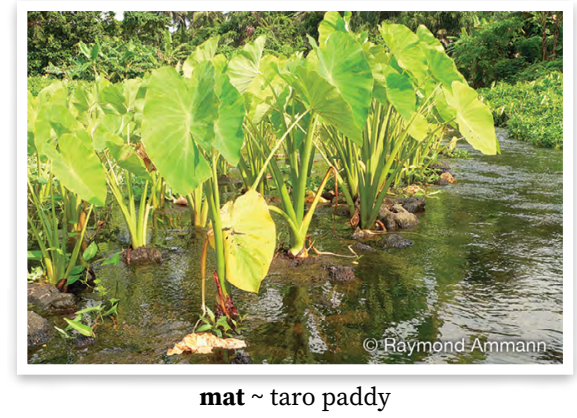

mat bōak taro garden planted in mud with no stones, where water wells up when the ground is dug 
garen taro we ol i planem long sofmad, we i nogat ston mo wota i kam antap taem ol i digim graon

mat vetvet taro garden planted only in stones with running water garen taro we ol i planem long ples we wota i ron long ol ston

mat wöwörös taro garden planted in small stones and thin soil with running water $\sim$ garen taro we ol i planem long ples we $\mathrm{i}$ gat ol smolsmol ston mo wota i ron long hem

n̄en̄ere garden garen

qèel (pl. qēlaqēl) taro paddy; garden for planting taro which is sometimes irrigated and sometimes not during the period of growth. The taro are planted in dry ground, then irrigated, then drained for weeding, then irrigated again kaen garen taro we ol i planem long drae graon, afta ol i putum wota, afta lego wota long taem blong widim

qël grow and spread out (of vine or yam) rop i gro mo spred aot

ran̄rañ clean garden $\sim$ klinim, katem garen

riv ${ }_{1}$ plant $\sim$ planem

rivriv plant $\sim$ samting we yu planem

rot taro garden $\sim$ garen taro

rönö plant stake in ground for yam to grow up planem wud long graon blong yam i save gro long hem

sar $_{4}$ pull out, referring to pulling taro from ground pulumaot, olsem pulumaot taro long graon

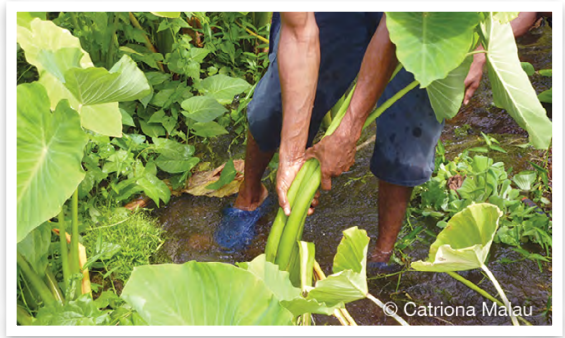

sar pull out taro sartan first sign that yam is starting to dry out $\sim$ fes saen blong yam i stap go drae (lif i yelo o rop i drae)

sigsig harvest taro from paddy gardens $\sim$ karem taro long garen

sōwereg plant yam or water taro in the same place where it was dug up planem yam o wota taro i gobak long sem ples we yu bin tekemaot

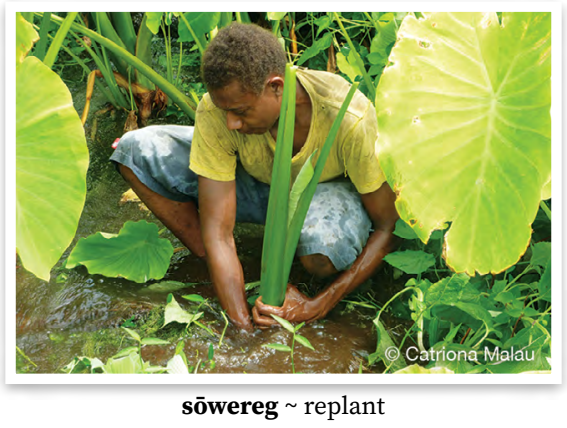

tin̄ taro paddy unit within a qēl, mat or bōak separated by mud or stone walls step insaed long garen taro tiqū garden $~$ garen

tōw ${ }_{2}$ grow $\sim$ gro

$\operatorname{var}_{2}$ plant (island cabbage) planem (aelan kabis)

varwëgsērēt first flooding in process of irrigating of taro paddy. In this step the water remains in the paddy for five days before it is drained fas taem we yu putum wota i go long garen taro blong i stap faef dei vas plant taro $\sim$ planem garen taro

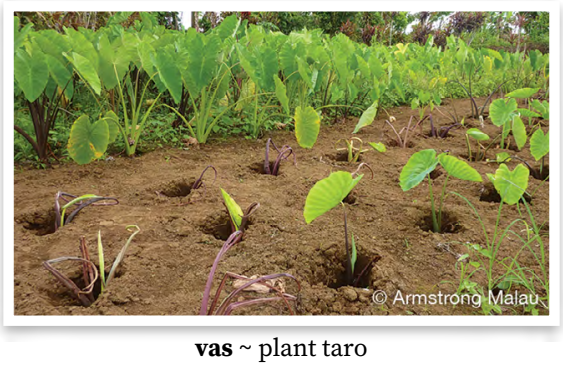

vaslē area where lots of taro gardens $(q \bar{e} l)$ are all planted together $\sim$ ples blong fulap garen wota taro $(q \bar{e} l)$ 
vug $_{1}$ row of yams in garden ro blong yam long garen

vun section of yam garden $~$ eria blong garen yam

vuteg plant (yam) planem (yam)

wewestel area that used to be a vegetable garden, which is not currently being tended, but still produces produce, so people can go there to harvest crops $\sim$ ples blong olfala garen we ol man ol i nomo planem kakae long hem, be ol kakae i stap gro yet, mekem se ol man ol i save go karem kakae long ples ia wēviñ piece of yam for planting pis yam blong planem

wōsōk taro garden that is planted in dry ground and not irrigated $~$ garen taro we ol i planem long drae graon nomo

wörönö stake, length of wood inserted in ground for yam vine to grow up wud blong planem long graon blong yam i save gro long hem

wöwör weed widim

\section{T Fire and cooking}

T1 Fire

$\mathbf{e v}_{1} \mathbf{1} \cdot$ fire $\sim$ faea $\mathbf{2} \cdot$ hell $\sim$ hel

ga burn up, burn out of control bon nogud

nōn (of fire) burn down to coals, ready for cooking go daon (faea) redi blong kuk

ralēt firewood $\sim$ faeawud

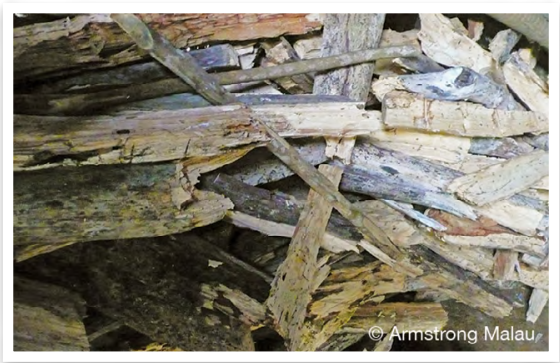

ralēt $\sim$ firewood

rēe draw leaf, such as coconut, pandanus, heliconia, over fire to make more hardy and supple for use in weaving and cooking bonem lif long faea, olsem kokonas, pandanas, lif laplap, blong mekem se i sofsof mo i save stap longtaem sul 1 • light (fire) laetem faea $\mathbf{2} \cdot$ burn (something) bonem (samting) susul 1 - burn a bird after plucking $\sim$ bonem pijin taem yu tekemaot feta finis $\mathbf{2}$ - irritate mouth (said of taro and wild yam) $\sim$ taro o wael yam i kakae man

tum $1 \cdot$ burn bonem 2 - burn, be burnt $\sim$ bon

tuwegev (fr.var. tuwëgev) make fire in stone oven $\sim$ mekem faea insaed long oven

watavren charcoal jakol

wōwō ashes asis

T2 Food preparation, cooking,

distribution, eating

an be uncooked, not properly cooked $\sim$ no dan gud

bal $_{1} \mathbf{1} \cdot$ use wooden tongs to pick up hot stones or charcoal from stone oven $\sim$ tekemaot ston o jakol long oven wetem wud $\mathbf{2}$ - cut (with scissors) katem (wetem sisis)

big eat (meat, greens, protein with main meal) kakae (mit o kabis wetem kakae) 
bigbig meat, greens, protein component of meal mit, pat blong kakae we i no men kakae, olsem kabis o kokonas

big töw eat grated coconut flesh, as you scrape it out of the shell, either on its own or with a staple food kakae kokonas, taem yu skrasem kokonas, yu kakae hem wan o tugeta wetem wan kakae

bōnësnës fill length of bamboo with food (e.g. taro, yam, meat, prawns) and roast over fire $\sim$ fulumap kakae insaed long bambu mo rusum long faea

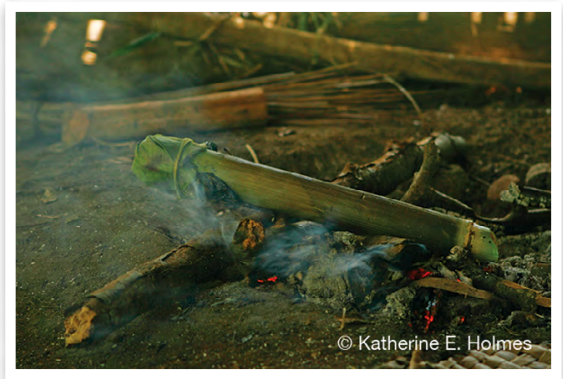

bōnësnës cook in bamboo

bun place stones on fire of oven putum ston antap long faea

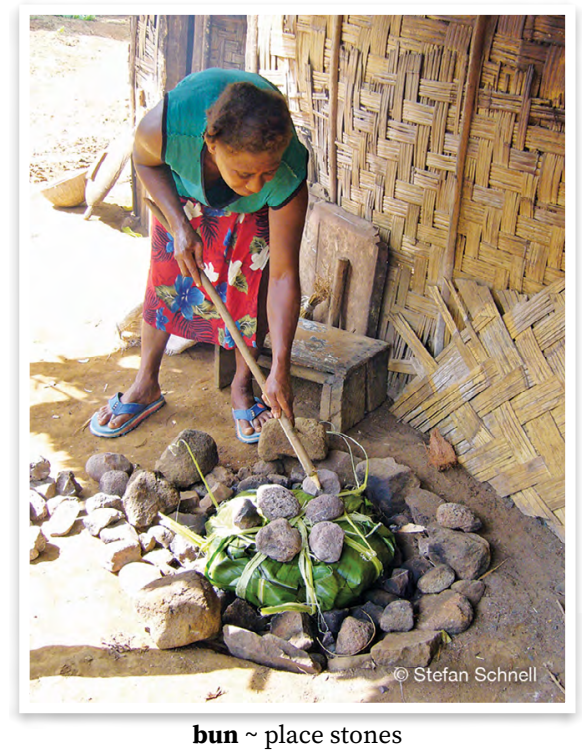

demete leaves fastened together and used to cover opening of stone oven ol lif we ol i fasem tugeta blong blokem ae blong oven

dēdērēs taste good swit

dētēriv leaves of cottonwood tree that have been pinned together to produce a large leaf mat that is used to cover over food when it is baking in stone oven $\sim$ stikim tugeta lif blong burao o navenue blong mekem i bigwan blong kavremap kakae taem i bek long oven

dër rot, be rotten, as in food deteriorating or other items disintegrating roten, olsem kakae, klos, haos

diat mushy, soft (of food that has been overcooked) sofsof kakae we i dan tumas, olsem raes i kam olsem laplap, o yam i tumas wota

dōleg mix löt food dish after it has been pounded $\sim$ miksim nalot wetem wud afta yu bin kilim finis

dōrōq cottonwood leaves fastened together to form a lid for covering the opening of a steam oven lid blong blokem ae blong oven we ol i mekem long lif blong burao o navenue

en flatten out löt ñe mereñ food dish flatem kaen nalot ia we ol i kolem se löt ñe mereñ

gabal long wooden tongs used for picking up hot stones or charcoal from stone oven wud blong karemaot ston long oven 


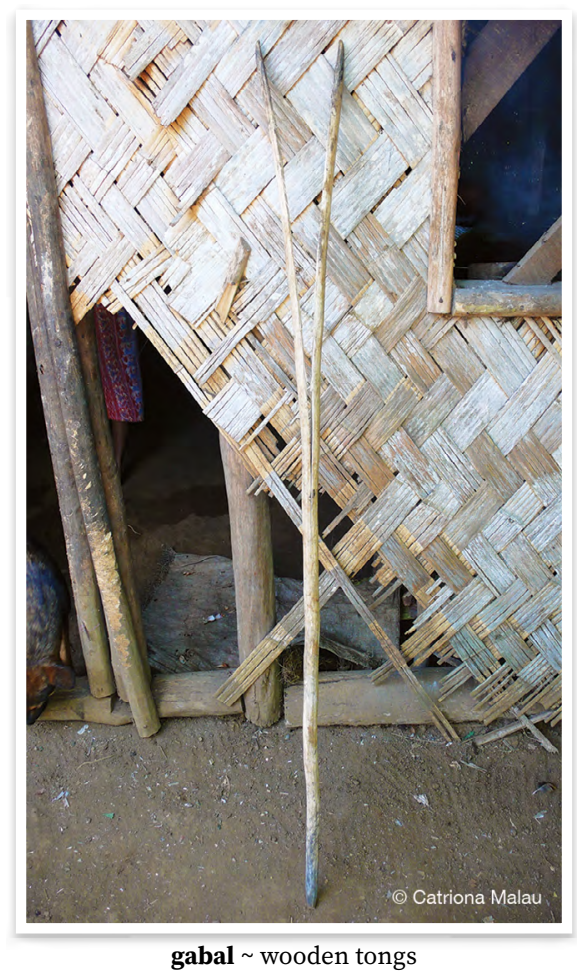

galēm long wooden pole used for evenly spreading charcoal and heat of stones in stone oven wud blong miksimap jakol mo ston long oven

gatitimeles piece of wood with hooks on it for hanging food in the kitchen $\sim$ wud we i gat huk long hem we ol i hangem antap blong hangem kakae long hem

gen $_{1}$ eat, eat staple part of meal kakae, kakae men kakae

gengen $\mathbf{1}$ - food, meal, staple part of meal, either cooked or uncooked kakae, men kakae, we i dan o i no dan $\mathbf{2}$ - food crops, staple food plants $\sim$ kakae long garen

gengen luwō feast $~$ bigfala kakae, lafet

gengen luwömeren eat lunch, meal in middle of day kakae dina gengen revrev eat dinner, evening meal kakae long sapa gengen vōrōg eat breakfast dring

ti long moning

genvēl something that you don't want to eat but you must force yourself to eat samting we yu no wantem kakae be yu mas kakae mo yu fosem nomo blong kakae

genwiwiris fussy eater, someone who is choosy about what they want to eat and won't eat if you cook something other than what they want man we hem i jusum kakae we hem i wantem nomo mo sapos yu kukum nara kaen kakae bae hem i no wantem kakae

geres grate coconut skrasem kokonas

gëvtun make meal using method where the food is wrapped in leaves, then place the parcel of food on top of the coals of the fire mekem kakae folem fasin we yu paselem kakae fastaem, afta yu putum long faea. Samtaem yu save rusum kakae fastaem

gil 1 - dig, dig up food plants, etc. digim 2 - digging stick $\sim$ stik blong digim graon $\mathbf{3}$ - Stick used for removing husk from coconut $\sim$ wud blong karemaot skin long kokonas

gök $\mathbf{1}$ • boil boel $\mathbf{2}$ - bubble, dissolve $\sim$ boel (meresin)

gör grate (coconut), scrape out insides of something firm $\sim$ skrasem kokonas, skrasemaot insaed long wan samting we i strong

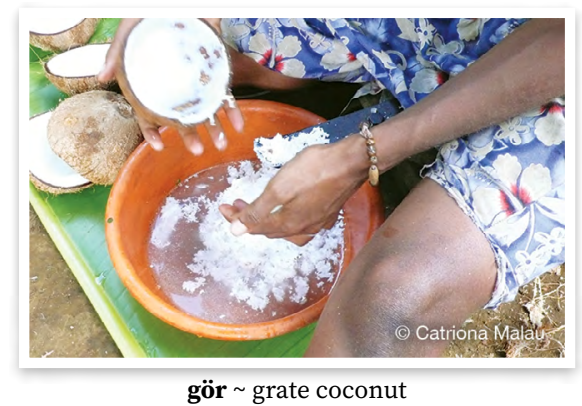


kuk cook, used occasionally as generic cooking term, but more commonly with specific reference to cooking food in a saucepan, rather than over fire or in stone oven kuk, kuk long sospen

kurqar not cooked properly hafdan, kakae we i no dan gud

lèm stir up and spread charcoal and hot stones in stone oven with long stick (galèm); use lever action yusum wud (gatēm) blong tekemaot bigfala pis wud o jakol long bigfala oven blong vësëw bifo i redi blong putum kakae

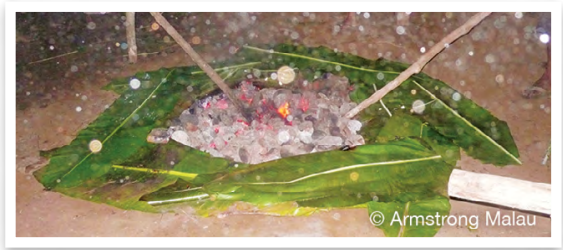

lēm lever with stick

lik serve food, remove food from oven

sevem kakae, karemaot kakae long oven

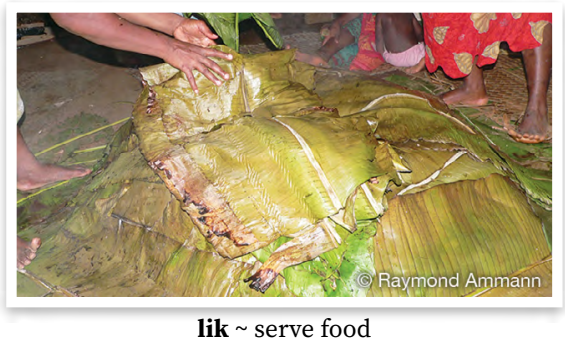

liqet cover food with large leaves for cooking in stone oven $\sim$ kavremap kakae wetem lif insaed long oven

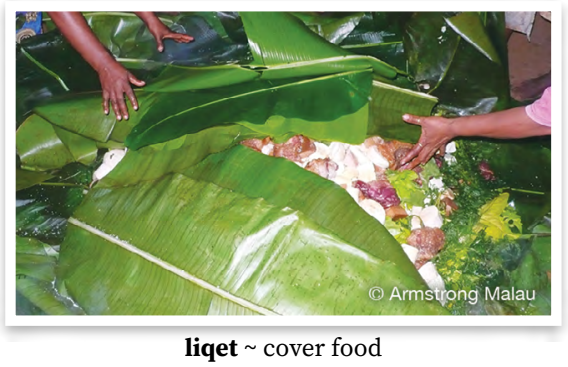

meteges wooden knife for cutting löt food dish wuden naef blong katem nalot

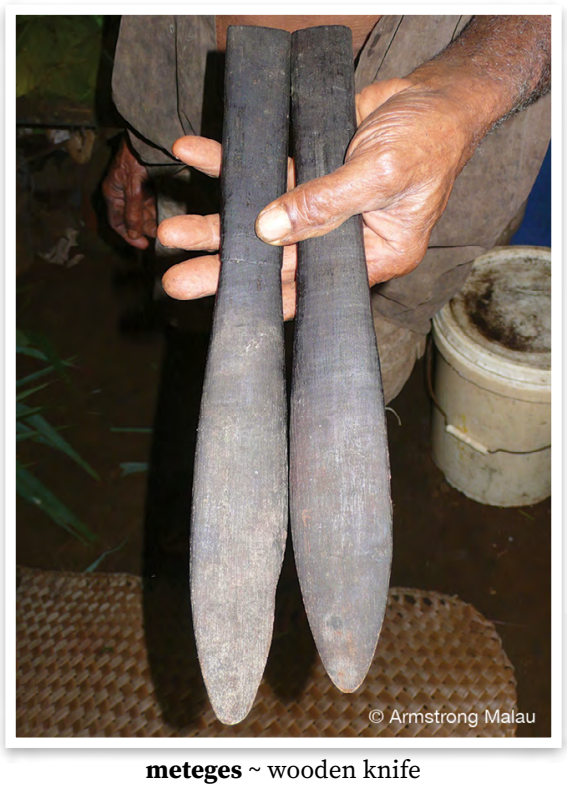

monog cooked $\sim$ dan

$\bar{n}_{2}$ eat only meat without the staple part of a meal kakae mit witaot kakae

nal ${ }_{3}$ chew, as something chewy like toffee, bubble gum juim, kakae samting we i taf

qan̄ris (fr.var. qarn̄is) $\mathbf{1}$ - method of baking in stone oven $\sim$ fasin blong bek long oven $\mathbf{2}$ bake food in stone oven bek, bekem kakae long oven qar $\mathbf{1}$ - unripe $\sim$ no raep $2 \cdot$ raw, uncooked $\sim$ no dan $\mathbf{3} \cdot$ undried, untreated, as of green leaves, rather than dried or heat treated leaves no drae, no dan, olsem lif we i grin nomo, we ol i no putum long faea blong mekem i strong

q $\overline{\mathbf{o}} \mathbf{t} \overline{\mathbf{o}}_{2}$ cupboard that is built over the fire in kitchen to store canarium nuts or breadfruit, so that they are dried and kept safe from rats $\sim$ haos blong putum drae nangae o bredfrut 
insaed long hem. Hem i go ova long faea mo ol i somap doa blong rat i no save kakae ol nangae o bredfrut

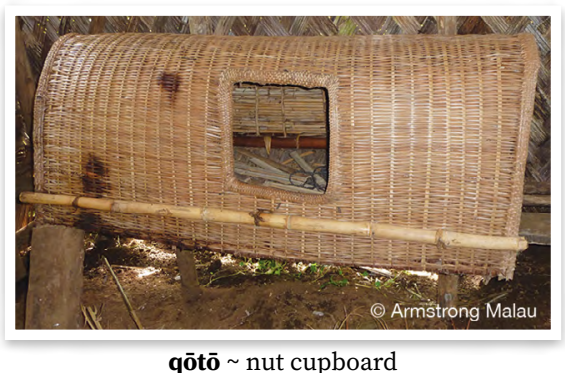

qusmamas eat a meal without any meat kakae drae, kakae kakae we i no gat mit blong hem

ras 1 - grate nuts or tubers for nalot or laplap rasras, salem kakae $\mathbf{2}$ - sharpen $\sim$ sapenem

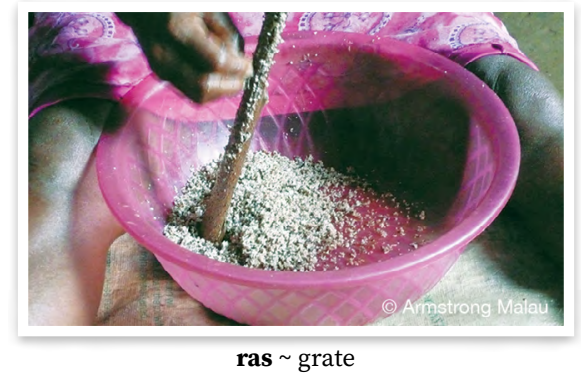

rèn̄ē roast meat over fire or charcoal rusum mit long faea

rötö heat leftover food, reheat next to fire or on coals, to prevent from going off $\sim$ hitim namalas blong mekem se i no sting

sal mamēgin style of making meal by which staple foods are wrapped with meat and greens in heliconia leaves with hot stones inside to help the food cook stael blong mekem kakae we yu pasolem ol hot ston insaed long lif laplap wetem kakae, mit mo kabis

salsal make meal by wrapping staple food with meat and greens in heliconia leaves with hot stones inside to help the food cook, the food is then placed on hot stones or coals so that it is cooking from inside and outside the parcel mekem kaen kakae we yu paselem kakae wetem mit, putum hot ston insaed bitwin lif laplap, mo afta yu putum long faea

sēm 1 - peel, remove skin from (something hard, as uncooked vegetables, copra) tekemaot skin (blong samting we i strong olsem taro o kopra) 2 - remove coconut flesh from shell and husk, to produce copra $\sim$ selaotem

sir $1 \cdot$ scrape, scrape dirt from the outside of taro and other root vegetables skrasem doti (blong taro) $\mathbf{2}$ - remove skin, bark tekemaot skin

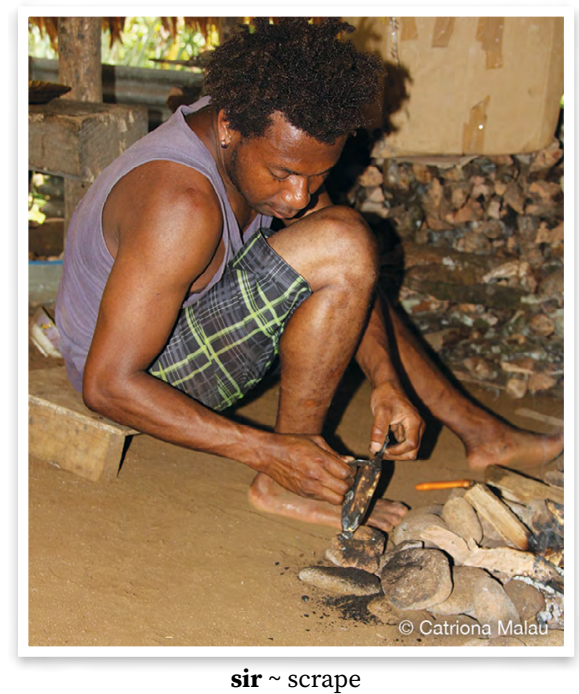

sum drink dring

sumsum 1 • drink $\sim$ dring $2 \cdot$ alcohol, alcoholic beverage $\sim$ dring, alkohol

tabē carved wooden platter, used for pounding nalot and making kava natambia, wuden plet

tētēw smoke, dry over smoke smokem

wètētēw wood for smoking wud blong smokem 
tumsölönev food is burnt on the outside but raw in the middle after roasting in a fire that is too hot kakae $\mathrm{i}$ bon long afsaed be i no dan long insaed, taem yu rus be faea i hot tumas

tun roast staple foods, as taro, banana, cassava, etc. (not meat) over fire or embers fasin blong rusum kakae we yu putum ova long faea o jakol

tuntun roast food $\sim$ rus

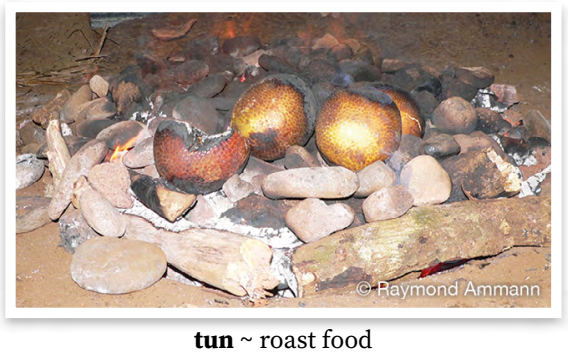

tuwegev (fr.var. tuwëgev) make fire in stone oven $\sim$ mekem faea insaed long oven

um oven made by digging hole in the ground and baking food with hot stones $\sim$ graon oven

um val kind of stone oven for which a big hole is dug in the ground, which is then filled with big stones kaen oven we ol i digim hol, afta fulumap wetem bigfala ston

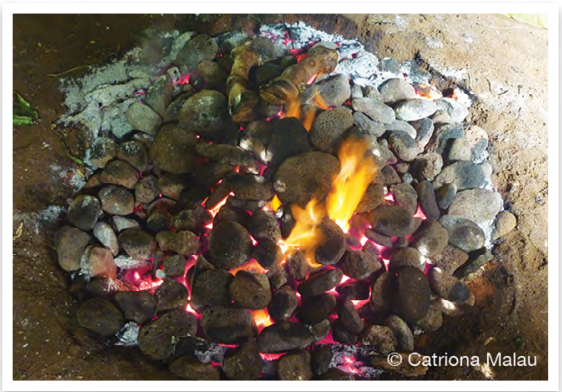

um $\sim$ stone oven

vësëw 2 • stone oven $\sim$ hol blong oven 2 - bake food in stone oven $\sim$ bekem kakae long oven via grater for grating nuts and tubers to make laplap and nalot samting blong salem nangae o ol kakae via qatē grater made from stem of tree fern samting blong salem laplap, nat o samting olsem we ol i mekem long blakpam

via tin grater made from old tin that has holes punched into it samting blong salem laplap, nat o samting olsem we ol i mekem long tin

vun 1 pour water into oven to produce steam by which food will cook kapsaedem wota antap long kakae long oven

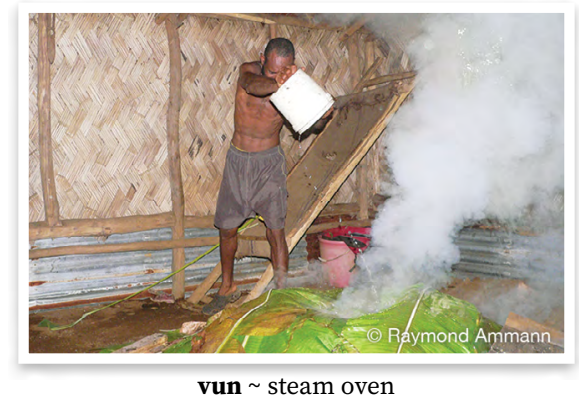

vutulöt (fr.var. vötulöt) large wooden pestle used for pounding löt food dish wud blong kilim nalot

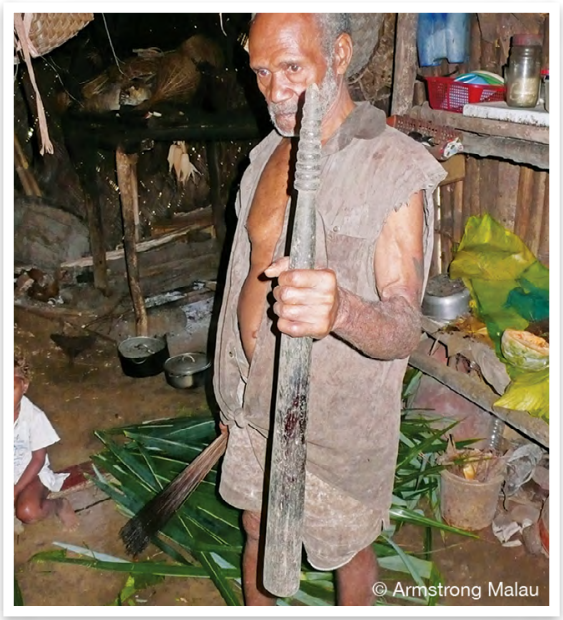

vutulöt wooden pestle 
weger tele metal coconut grater aean blong skrasem kokonas

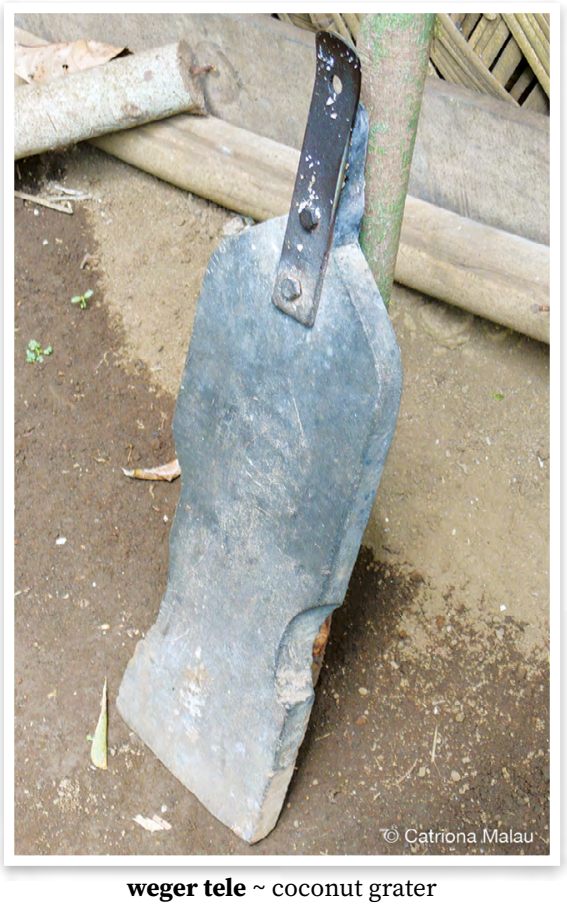

wetele lan̄lan̄ metal rods used as support for saucepan when cooking over fire aean blong ples blong kuk

wosleqen method for cooking meat or fish by grilling a little, then wrapping up in leaves with salt and cooking again on coals $\sim$ fasin blong kukum mit o fis we yu putum long faea smol fastaem, afta paselem long lif wetem sol mo kukum long faea bakegen

wosvalqeñ cooking method kaen fasin blong kuk

wōr 1 1 squeeze liquid out of (coconut, ground kava, etc.) melekem 2 • squeeze coconut milk onto food, either before or after cooking melekem (kakae)

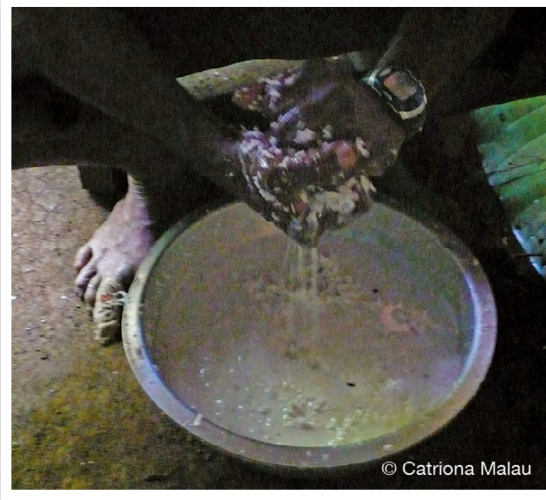

wōr squeeze liquid from

wōr logomonog cooking style where food is cooked first then coconut milk is squeezed on top without being cooked again stael blong mekem kakae we yu mekem kakae i dan fastaem, afta yu melekem

wōr qarqar cooking style where coconut milk is squeezed over uncooked food before being cooked, either in saucepan or parcel in oven or over fire stael blong kuk we yu melekem kakae fastaem, taem i no dan yet, afta yu kuk long sospen o pasolem mo bek long ston

wul peel, remove skin (from something which is soft and easy to peel, like a banana or vegetables which have been cooked) tekemaot skin (blong samting we $\mathrm{i}$ isi olsem banana o bredfrut we i dan) 


\section{U Human uses of natural resources}

\section{U1 Food}

biliagtat kind of laplap food dish that has two layers of laplap with a layer of grated canarium nuts between, either roasted or raw wan kaen laplap we $\mathrm{i}$ gat tu laen wetem grin o drae nangae long medel

bunia food dish, where different kinds of root vegetables are baked in leaves in stone oven with coconut milk bunia

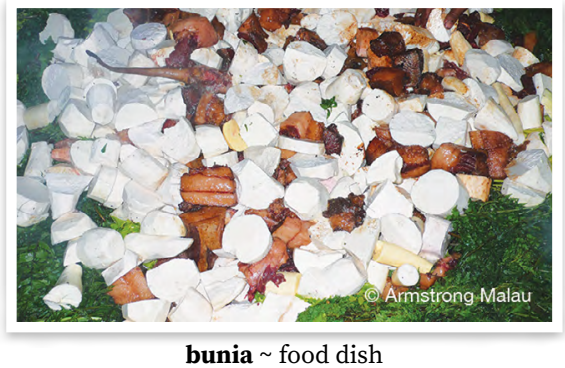

dagawis (fr.var. diwis) young leaf of breadfruit, which is cooked and eaten as greens $\sim$ top blong bredfrut, blong kakae olsem kabis

döwis soft edible tips of breadfruit leaves top blong bredfrut

garat food scraps (e.g. taro skin, fish bones) doti blong kakae (olsem bun blong fis, skin blong taro)

gargarmamas fast, refrain from eating certain foods for a particular reason $\sim$ lego kakae mo dring

garte 1 - leftovers, part remaining from something pat we i stap yet 2 - leftovers, food that someone has left uneaten $\sim$ hafkakae gartan her/his/its leftovers hafkakae blong hem

garten nōtōn her child's leftovers hafkakae blong pikinini blong hem gartëk my leftovers hafkakae blong mi kör dried breadfruit biscuit, used as famine food after hurricane bredfrut biskit

lōk laplap, food dish made from grated tubers or banana, generally cooked in stone oven laplap

wōr lōk simboro, food dish made from grated banana or tubers, wrapped in leaves of Abelmoschus manihot and cooked in coconut milk $\sim$ simboro

lōlōs food dish that is made from grated canarium nuts and datamal leaves, wrapped up and cooked on hot stones wan kaen kakae we ol i mekem smolsmol pasel blong datamal lif wetem nangae we ol i bin rasras mo ol i paselem mo putum antap long hot ston

lör kind of laplap that has grated canarium nuts mixed in before being spread out and wrapped laplap we yu miksim wetem nangae, afta jas paselem

löt 1 - kind of food dish made from breadfruit, taro or cassava, which is boiled or roasted, pounded to make a thick paste, then mixed or covered with coconut cream or nuts $\sim$ nalot 2 . make löt mekem nalot

löt bulmarwe kind of food dish made from pounded root vegetables or breadfruit, which has grated roasted cutnuts on top wan kaen nalot we i gat drae navele antap long hem we ol i bin rasras

löt kel kind of food dish made from pounded root vegetables or breadfruit, which has roasted cutnuts mixed with sugarcane juice on top wan kaen nalot we $\mathrm{i}$ gat drae navele antap we ol i bin miksim wetem wota blong sugaken 
löt matwōnwōn kind of food dish made from pounded breadfruit, with a hole in the centre that is filled with grated cutnuts, cooked with hot volcanic stones $\sim$ wan kaen bredfrut nalot we ol i kilim finis mo afta rasras grin navele, putum insaed long hol long medel wetem hot ston, kavremap mo livim i dan (10-15 minit)

löt n̄e mereñ kind of food dish made from pounded root vegetables or breadfruit, with grated roasted canarium nuts on top wan kaen nalot we $i$ gat drae nangae antap long hem

löt ne qar kind of food dish made from pounded root vegetables or breadfruit, with grated raw canarium nuts on top wan kaen nalot we i gat grin nangae antap

löt salsim kind of food dish made from pounded root vegetables or breadfruit, topped with coconut milk that has been cooked until the oil separates from the caramelised coconut wan kaen nalot we ol i putum melek kokonas antap we ol i bin kukum go go i braon mo oel blong hem i kamaot

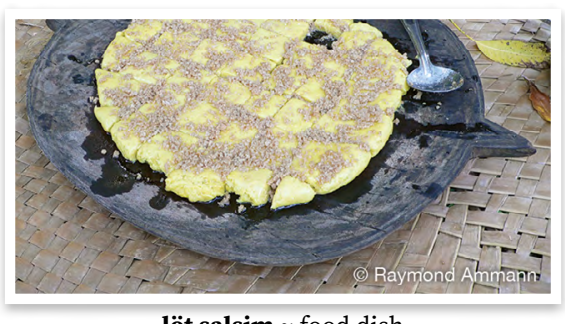

löt teqesēg kind of food dish made from pounded taro, with coconut milk poured in a hole in the centre, then the whole dish is wrapped in heliconia leaves and cooked over hot coals wan kaen taro nalot we ol i mekem hol long medel, melekem kokonas insaed, paselem mo putum antap long faea löt vasgēr kind of food dish made from pounded root vegetables or breadfruit, topped with caramelised coconut cream and oil that has been cooked in a coconut shell over the fire wan kaen nalot wetem kokonas antap. Ol i melekem kokonas long sel kokonas mo putum antap long faea blong mekem se oel i kamaot mo kokonas i braon

löt wirsal kind of food dish made from pounded root vegetables or breadfruit, topped with coconut cream that has been cooked by the heat of a hot stone inside a coconut shell wan kaen nalot we ol i putum melek kokonas antap. Ol i melekem insaed long sel kokonas we i gat hot ston insaed

löt wotag kind of food dish made from pounded root vegetables or breadfruit, topped with grated roasted cutnuts $\sim$ wan kaen nalot we $i$ gat drae navele antap

löt wötön̄ö kind of food dish made from pounded root vegetables or breadfruit, with a hole in the centre filled with grated green coconut flesh, which then has hot volcanic stones added, and is wrapped in heliconia leaves so that the coconut cooks wan kaen nalot we ol i rasras frut blong kokonas we i no grin be i no drae yet. Ol i kilim nalot finis, afta ol i mekem hol long medel mo putum kokonas wetem hot ston insaed. Afta ol i kavremap wetem lif laplap mo livim i dan (5 o 10 minit).

meles leftover food, food from previous day, which may need to be reheated namalas, kol kakae, hafkakae

mamas grated canarium nuts wrapped in datamal leaves and baked in a stone oven $\sim$ nangae we ol i pasolem long lif wetem lif blong datañal mo bekem long oven 
naw $\mathbf{1} \cdot$ sea $\sim$ solwota $\mathbf{2} \cdot$ sea water, salty water $\sim$ solwota $\mathbf{3} \cdot$ wave (of sea) $\sim$ wef (blong solwota) $4 \cdot$ salt $\sim$ sol

dōrdōrsenaw tide mark mak we solwota i kam so, we yu harem noes blong solwota long ples ia

nawēut rough sea solwota i raf

rirve if one only has a small amount of meat, soak small pieces of it in salty water, then when it is eaten with a meal, one will feel that it is sufficient sapos yu gat smol mit nomo blong kakae wetem kakae, sapos yu tekem smolsmol pis mit ia mo yu putum long wota wetem sol, bae i mekem se yu fulap long smol mit

rov $_{1}$ food dish made by mixing various leafy greens with grated raw canarium nuts, wrapping them and baking in stone oven wan kaen kakae we ol i rasras grin nangae mo paselem wetem defren kaen kabis, afta ol i bekem

salōqōs kind of food dish wan kaen nalot wetem melek blong kokonas antap. Ol i kukum kokonas blong mekem se i tik be i no braon

siaw $_{1}$ food dish in which sliced ripe breadfruit is layered with canarium nuts, wrapped and baked in stone oven wan kaen kakae we ol i slaesem raep bredfrut mo lerem wetem nangae we ol $\mathrm{i}$ bin rasras

sinag $\mathbf{1} \cdot$ taro $\sim$ taro $\mathbf{2} \cdot$ food, staple food kakae

tivtiv $_{2}$ cover made from sago palm leaves, used to cover breadfruit when baking in stone oven in order to keep heat in wan samting we ol i somap lif natanggura mo yusum blong kavremap bredfrut long oven blong kipim hit i stap insaed

wam̄amas $_{2}$ food dish in which grated canarium nuts are rolled up in datamal leaves, then wrapped in heliconia leaves and baked in stone oven kaen kakae we ol i rasras nangae, rolem long lif dataīal, pasolem long lif laplap, afta bekem

wewe kind of laplap that is rolled in island cabbage and then cooked in saucepan rather than baked laplap simboro

wëmën̄ël snack food (fruit, nuts) smol kakae olsem frut, nat

wir kind of laplap that is rolled in island cabbage, cooked in saucepan, sliced, then has coconut milk squeezed on top laplap simboro we ol i kukum fastaem, afta ol i slaesem mo melekem

wirmamēgin kind of food dish wan kaen nalot we ol i kilim nalot finis, ol i melekem kokonas stret antap

wōrkelkel kind of laplap that is made by mixing tuber or banana with coconut and wrapping in parcels to bake in oven wan kaen laplap we ol i salem maniok o wael yam o banana o kumala mo ol i miksim wetem melek kokonas bifo ol i bekem

\section{U2 Narcotics}

gē $\mathbf{1}$ - kava plant $\sim$ kava Piper methysticum $\mathbf{2} \cdot$ drink prepared from the roots of the kava plant $\sim$ kava we ol i mekem dring aot long rus blong hem

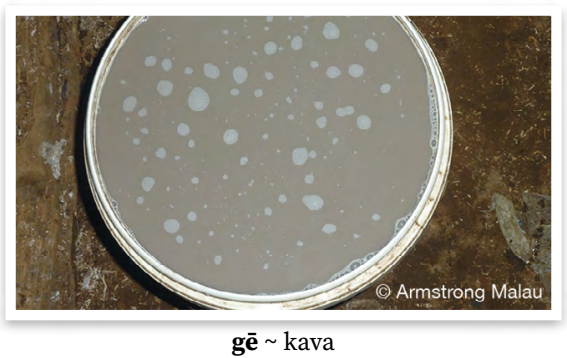

is homebrew made from yeast $\sim$ dring we ol i mekem long yis

sum drink dring

sumsum $\mathbf{1} \cdot$ drink $\sim$ dring $\mathbf{2} \cdot$ alcohol, alcoholic beverage $\sim$ dring, alkohol 


\section{Thinking, perception and attention}

V1 Sense and perception

\section{V1.1 Seeing}

èl $\mathbf{1} \cdot$ see $\sim$ luk $2 \cdot$ look lukim èlēl $1 \cdot$ view, vision, insight, opinion $\sim$ lukluk 2・ light laet

èl rak recognise, realise (by seeing) luk save

rērēt peep, peek, look secretively or with particular intent $\sim$ pusum hed blong luk haed

sēk look for lukaotem

V1.2 Hearing

rōn̄teg $\mathbf{1}$ ' hear harem $\mathbf{2} \cdot$ feel, sense $\sim$ harem, filim

tinqōōr listen (to) lesen

V1.3 Tasting and smelling

rōn̄ōbōn smell, passive sense of smell $\sim$ harem smel

sōbōn smell, sniff scent, active sensing of smell smelem

\section{V1.4 Physical sensations}

gis $1 \cdot$ hold, carry, hold onto $\sim$ holem, karem $\mathbf{2} \cdot$ touch $\sim$ tajem $\mathbf{3} \cdot$ host, hold celebration, ceremony $\sim$ hostem lafet, seremoni

rōn̄teg $\mathbf{1}$ • hear harem $\mathbf{2}$ • feel, sense $\sim$ harem, filim

V2 Cognition

\section{V2.1 Mental states}

malaklak $\mathbf{1} \cdot$ happy $\sim \operatorname{glad} \mathbf{2} \cdot$ happiness $\sim \operatorname{glad}$

metegrōw afraid, frightened $\sim$ fraet mēr $\mathbf{1} \cdot$ angry, be angry $\sim \operatorname{kros} \mathbf{2} \cdot$ anger $\sim$ kros

mëtëwtëw 1 - afraid, frightened fraet $\mathbf{2} \cdot$ afraid of, frightened of $\sim$ fraet long

mā̄al surprise $\sim$ sapraes qaqa 1 - silly, ridiculous behaviour, ridiculous behaving person krangke, krangke fasin 2 - crazy person, behave in a ridiculous way $\sim$ mekem ol samting we i no stret olsem i hafmad; man we i krangke 3 - stupidly, not properly, randomly olbaot, long krangke fasin

qeneg $\mathbf{1}$-afraid, frightened $\sim$ fraet $\mathbf{2}$ • fear, be afraid of $\sim$ fraet long qiriag confuse $\sim$ konfiusem rōrōn̄ $\mathbf{1} \cdot$ slowly sloslo $\mathbf{2} \cdot$ quietly kwaet $\mathbf{3} \cdot$ calmly, still $\sim$ kwaet tutuag worry, suffer $\sim$ wari

\section{V2.2 Mental processes and experiences}

dödöm think, think that, think about $\sim$ ting, ting se

dödöm tutun think strongly, be determined $\sim$ tingting strong blong mekem wan samting

dödömia 1 - thought, thinking, idea $\sim$ tingting $\mathbf{2} \cdot$ meaning $\sim$ mining

döm kēl think about, remember tingbaot

döm mav $\mathbf{1} \cdot$ respect $\sim$ ting hevi, respek $2 \cdot$ respect $\sim$ respek

döm siër think about, think of tingbaot

döm viteg 1 - forgive fogivim 2 • forgiveness $\sim$ fogivnes

ēl rak recognise, realise (by seeing) luk save

gilal $\mathbf{1} \cdot$ know $\sim$ save $\mathbf{2} \cdot$ knowledge, wisdom $\sim$ save, waes $\mathbf{3} \cdot$ jealous, express jealousy jalus

lugög plan plan

luw count (something) kaontem

matgagar anger ae i kros

nōmtuv 1 • believe biliv $2 \cdot$ belief $~$ bilif

qōr forget $\sim$ foget, fogetem 
qōrqōr $\mathbf{1} \cdot$ dream $\sim$ drim $\mathbf{2} \cdot$ dream about $\sim$ drim long $\mathbf{3} \cdot$ dream $\sim$ drim $\mathbf{r e ̄ v _ { 2 }}$ write $\sim$ raetem

rōñteg rak understand, sense, comprehend, realise $\sim$ harem save vasērēg 1 - think about, consider tingbaot $\mathbf{2} \cdot$ idea, thought $\sim$ tingting vasōgō read ridim

vēvēg ${ }_{1}$ count (something) kaontem

V2.3 Knowledge and learning

daēl try traem

dun $\mathbf{1} \cdot$ true, be true, real $\sim$ tru $2 \cdot$ sure, tell truth $\sim$ sua, tru $3 \cdot$ truth $\sim$ tru gilal $1 \cdot$ know save $2 \cdot$ knowledge, wisdom save, waes $\mathbf{3} \cdot$ jealous, express jealousy jalus

lōlōmeren $\mathbf{1} \cdot$ wise, intelligent $\sim$ waes $2 \cdot$ wisdom, knowledge $\sim$ waes, save mav $1 \cdot$ heavy hevi, no laet $2 \cdot$ difficult, hard, not easy $\sim$ had, no isi qaq totono advice $\sim$ advaes

skul 1 • school skul 2 - go to school, carry out schooling skul, go long skul

tono $\mathbf{1}$ - learn lanem 2 - teach, instruct $\sim$ lanem, tijim

vasösöv advise, instruct givim advaes long

\section{W Handling and physical transfer}

\section{Wo General}

salmiat be ready, be prepared $\sim$ redi taōrmat 1 - be ready, be prepared redi $2 \cdot$ prepare, make something ready $\sim$ mekem redi

da taōrmat prepare $\sim$ mekem redi

W1 Taking, touching, obtaining

bet pick up pikimap

bël $1 \cdot$ steal $\sim$ stilim $2 \cdot$ record, with audio or video recorder $\sim$ rikodem voes o video

dēñ $\mathbf{1} \bullet$ arrive $\sim$ kasem $\mathbf{2} \bullet$ reach, arrive at $\sim$ kasem

gövut pull out something that is tightly held within something, as in ground, uproot pulumaot wan samting we $i$ fas gud bitwin o insaed long wan samting, olsem pulumaot wud long graon

kal ${ }_{1}$ pull in fishing line, pull up fish pulum string

kulum $_{3}$ gather together in bundle and tie up mekem bandel mo fasem taet le 1 • take tekem $\mathbf{2} \cdot$ get, bring karem, karem i kam $\mathbf{3} \cdot$ give $\sim$ givim le den remove, take away, take out karemaot

mem put putum

nës put into (container) fulumap insaed wan samting

qal 1 • affect, attain, reach $\sim$ kasem 2 • be first kam faswan

$\mathbf{s a n}$ touch, hold just with fingertips $\sim$ holem, tajem be wetem fingga nomo, i no wetem hol hand

sar $_{4}$ pull out, referring to pulling taro from ground pulumaot, olsem pulumaot taro long graon

sër ${ }_{3}$ wear, put on (clothes, accessories)

$\sim$ werem, havem (klos, savat)

sër lō take off, remove (clothes, accessories) karemaot (klos)

sëwëw grab, catch something with quick movement kasem kwiktaem nomo

soko catch $\sim$ kasem

sōk find faenem

sön̄ön put inside (container) fulumap insaed

sösögöt find faenem 
tañqal touch (with hand) tajem (wetem han)

tēk touch gently tajem sloslo, tajem smol

tiqër grab with two hands, tackle, wrap arms around kasem, holem taet

tut ${ }_{3}$ pull using quick sharp motion pulum taet hariap

ut collect water $\sim$ kasem wota

wö̀wör weed $\sim$ widim

W2 Holding, carrying, moving something around

bēm ${ }_{2}$ carry (baby) with piece of cloth, carry person or thing on back karem pikinini o man long baksaed

bēmn̄eg (fr.var. bimn̄eg) carry on shoulder, hang over shoulder, as carrying basket with strap over shoulder and basket hanging down karem long solda, hangem long solda, olsem basket

gan̄veg lead lidim

kuëg shake, move, push on swing sekem muvum, pusum

lik serve food, remove food from oven sevem kakae, karemaot kakae long oven

rak $_{2}$ lift, lift up leftemap

$\mathbf{r e ̄ v}_{1}$ pull pulum

rêv vasese pull canoe out of the water to the tideline, so it is half in and half out, in case a quick getaway is needed pulum kenu i kam antap smol nomo, haf long solwota, haf aotsaed, blong mekem se yu save pulum i go daon hariap sapos yu wantem go kwiktaem

rieg away from, out, out of the way aot long

sas carry something heavy, holding with one hand on either side, or two people carrying, one on each side $\sim$ karem, wan i holem wan saed, narawan i holem narasaed, o wan man i yusum tu han blong leftemap

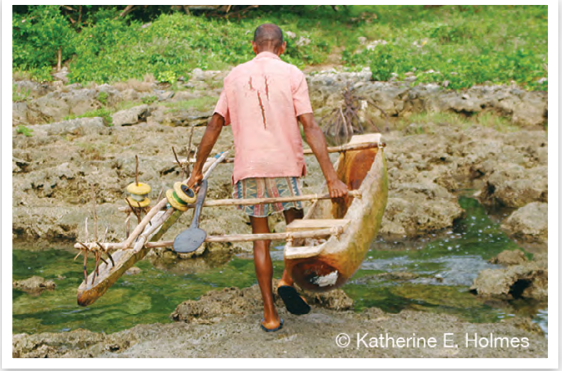

sas carry

sesen carry something heavy, holding with one hand on either side, or two people carrying, one on each side $\sim$ karem, wan i holem wan saed, narawan i holem narasaed, o wan man i yusum tu han blong leftemap sër ${ }_{1} \mathbf{1} \cdot$ spill, be spilt $\sim$ kapsaed $\mathbf{2} \cdot$ spill, pour, tip out (anything, either liquid or solid) kapsaedem

sōltek carry on one shoulder, especially heavy items $\sim$ karem (wan hevi samting) long wan solda

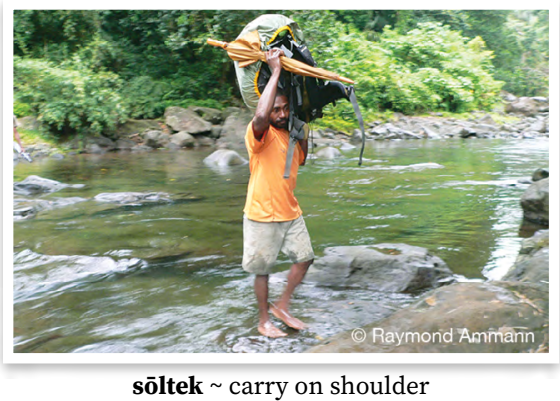

sōsōrvël carry using length of wood over shoulder, with half the load in front and half behind $\sim$ karem long wud long solda

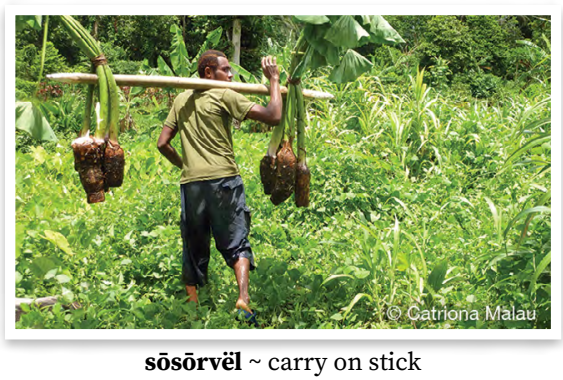


tatalēv carry load hanging on a stick held over shoulder karem wetem stik ova long wan solda

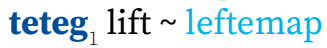

tiwil roll, toss around $\sim$ rolem

turm̄̄ō go first, be in front, lead stanap fastaem, go fastaem, lidim

vetrug stand up, erect stanemap

vëtur place in piles, pile up hipimap

W3 Letting go, giving, leaving be

bōl 1 - throw (something roundish and short) at $\sim$ stonem (wetem raon, sotfala samting) $2 \cdot$ fall down onto (of something heavy) (wan samting hevi) foldaon i go antap long

dun̄ög leave something with someone, leave something behind putum wan samting, livim i stap (olsem se bae yu jas kambak from o man i karem i kambak o wan i kam from)

gasēg share out, separate, divide seraotem

gatöqul throw (something long) at stonem (wetem longfala samting)

le 1 •take tekem 2 - get, bring karem, karem i kam $\mathbf{3} \cdot$ give $\sim$ givim

lër mix miksim

lin pour into something kapsaedem i go long wan samting qērēt push, push in button, push something down, press $\sim$ pusum

sër ${ }_{1} \mathbf{1} \cdot$ spill, be spilt $\sim$ kapsaed $\mathbf{2} \cdot$ spill, pour, tip out (anything, either liquid or solid) kapsaedem

susgeg push (stake or length of other material) into tight narrow space pusum (stik o samting olsem) i go fas long wan hol

susn̄eg push pusum

töqul throw away sakem

tövun (fr.var. tuvun) $\mathbf{1}$ • bury berem $2 \cdot$ fill in (hole), cover over something in hole $\sim$ berem

ukuëg 1 - depart, leave go, lego $\mathbf{2}$ - leave (place, person) lego $\mathbf{3}$ • release, let go of, allow to happen, let $\sim$ lego wan samting we yu holem 4 - leave something to continue, especially continue unaided for a time lego i stap

vēl ${ }_{3}$ divide, distribute, separate seraotem

vun 1 pour water into oven to produce steam by which food will cook kapsaedem wota antap long kakae long oven

wöt $1 \cdot$ throw, throw away $\sim$ sakem $2 \cdot$ contribute, give $\sim$ givim, sakem

\section{$X$ Impact and surface contact}

\section{Xo General}

da titisē damage, affect something in a negative way $\sim$ spolem

kōn snap, bend and break brekem

lam bash, hit, beat strongly kilim strong

lam̄eg bash against something hard, like a stone $\sim$ kilim long ston o long wan samting we i strong

qēs bang against something bangem $\mathbf{q} \overline{\mathbf{o}} \mathbf{s}_{1} \mathbf{1} \cdot$ pound, as in pounding löt with pestle, pounding clothes against rock $\sim$ kilim, olsem blong mekem nalot 2 - wash (clothes) $\sim$ wasem (klos)

qōs do pound leaf used for poisoning fish and mix with sand $\sim$ stonem lif blong posenem fis mo miksim wetem sanbij

sēr tear, rip terem

töwös hit kilim 
tut ${ }_{1}$ punch faetem

weteg crack, break open, split splitim

wor break, split open $\sim$ brekem

wos $_{1} \mathbf{1}$ - bash, slap, pound; hammer, bash (nuts) to crack open $\sim$ hamarem 2 build bildim

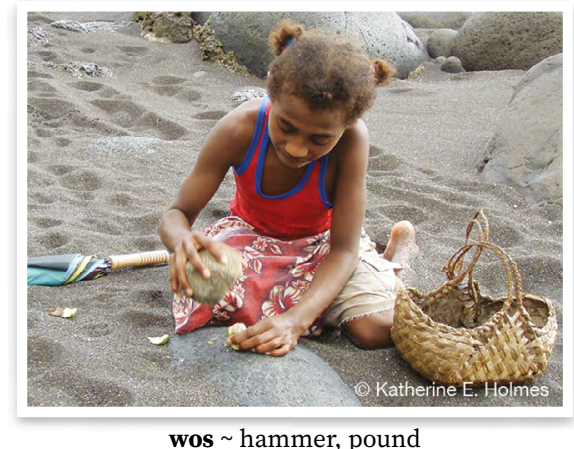

\section{X1 With an instrument}

bal $_{1} \mathbf{1} \cdot$ use wooden tongs to pick up hot stones or charcoal from stone oven $\sim$ tekemaot ston o jakol long oven wetem wud $\mathbf{2}$ - cut (with scissors) katem (wetem sisis)

es $1 \cdot$ spear sperem $2 \cdot$ pierce, poke, use sharp pointed object to pierce something stikim, yusum wan samting we i sap long en blong hem blong stikim wan samting

es do pound leaves for making fish poison mekem posen lif, sperem lif wetem wud blong mekem plante es mōtō remove husk from coconut sperem kokonas blong karemaot skin

ger chop, cut using chopping action with considerable effort required for effect, as object is solid, hard katem, olsem yu katem wan samting we i strong mo yu mas hadwok long hem

ras $1 \cdot$ grate nuts or tubers for nalot or laplap rasras, salem kakae $\mathbf{2}$ • sharpen $\sim$ sapenem $\mathbf{r e ̄ v _ { 2 }}$ write $\sim$ raetem

rōt cut with shell or small knife, placing finger on edge of knife or shell to guide and support the cutting action katem long naef o sel mo yu yusum fingga blong gaedem

sus 1 - poke, prod, pierce stikim $2 \cdot$ point (with finger) $\sim$ poen (wetem fingga) $\mathbf{3} \cdot$ inject, give injection to stikim (wetem stik meresin)

$\operatorname{tar}_{1}$ chop, cut using chopping action with considerable effort required for effect, as object is solid, hard katem, olsem long akis we i hadwok blong mekem

tes $_{2}$ carve, use knife or chisel to cut and shape something from wood katem wud

tes ak carve canoe $\sim$ katem kenu

tè-q $\mathbf{q}_{2}$ shoot (with gun) sutum (wetem masket)

tēv $\mathbf{1}$ • cut, slice $\sim$ katem, slaesem $\mathbf{2}$ • operate on $\sim$ katem (long hospitel)

tōt cut using chopping action, with minimal effort required for effect katem, jopem, be i no kadwok tumas

tutgëg stick, poke something into something stikim wan samting

vēn shoot (with bow and arrow or spear) sutum (wetem bonaro o spia)

vēnvēn go shooting go blong sut

\section{X2 Due to pressure}

bis pinch and twist to break off, as in picking (fruit) from tree $\sim$ karem (frut) long tri

qērēt push, push in button, push something down, press $\sim$ pusum

qirir grind kava graonem

wag $_{2}$ squeeze with hand, like massaging skwisim long han, olsem yu holem man 
X3 Sticking, tying, untying

lölös $\mathbf{1} \cdot$ wrap up pasolem $\mathbf{2} \cdot$ parcel $\sim$ pasol

mon $\mathbf{1} \cdot$ wrap up $\sim$ pasolem $\mathbf{2} \cdot$ parcel $\sim$ pasol

sö 1 • join joenem $2 \cdot$ joint, as in joint where two bones meet, joint in crafted wooden item joen, olsem joen blong tufala bun o joen long wud

ul 1 - come undone, unfastened kamaot (olsem samting we ol i bin fasem) 2 - undo, untie, unwrap, unfasten slakem, openemaot, karemaot (rop)

wōn 1 1 join, close up, seal together tufala saed i mit, olsem fasem lif, tufala saed i mit antap, kaliko i brok, joenem mo somap bakegen 2 • seal (hole in), join together, close up joenem, silim

wōnwōn ${ }_{1}$ whole, joined, complete fulwan

wöwös 1 - wrap up, most commonly used to refer to making a cone shape from leaf, filling it, then sealing pasolem, speseli ol i talem taem we ol i foldem lif olsem kon, afta pasolem kakae insaed 2 - parcel, wrapped up goods, food pasol, kakae o wan samting we ol i bin pasolem

\section{X4 Surface contact}

as $\mathbf{1} \cdot$ rub $\sim$ rabem $\mathbf{2}$ - wash, scrub (plates) wasem

er 1 peel off, remove pandanus leaves from trunk, cut around and peel off layer of wood from tree trunk karemaot pandanas long stamba

gör grate (coconut), scrape out insides of something firm skrasem kokonas, skrasemaot insaed long wan samting we i strong keres scratch, use scratching motion to dig skrasem, digim

kër ${ }_{1}$ scratch with fingernails skrasem, wetem sel fingga

men̄ wipe $\sim$ waepem

nem lick likim

rërës scratch skrasem

riam $_{1}$ rub rabem

$\mathbf{s} \overline{\mathbf{e}}_{1}$ peel bark from wood $\sim$ karemaot skin long wud

sēm 1 • peel, remove skin from (something hard, as uncooked vegetables, copra) tekemaot skin (blong samting we i strong olsem taro o kopra) 2 - remove coconut flesh from shell and husk, to produce copra selaotem

sërëvtës slip glis

sialtislañ slip glis

sir 1 - scrape, scrape dirt from the outside of taro and other root vegetables skrasem doti (blong taro) $\mathbf{2}$ - remove skin, bark tekemaot skin

siriv peel dried pandanus leaves from the plant $\sim$ karemaot lif pandanas we i drae finis long stamba

tëtës massage holem (bodi)

$\operatorname{var}_{1} \mathbf{1} \cdot$ stomp, tread heavily on prumbut $\mathbf{2}$ go in upwards direction $\sim$ go antap $\mathbf{3}$ - stand on, kick something with stanap long, kik samting wetem

vidir (fr.var. vēdir) $\mathbf{1} \cdot$ remove midrib from sago palm leaf $~$ tekemaot bun blong lif natanggura 2 - shoot liaw fish sutum liaw fis

wul peel, remove skin (from something that is soft and easy to peel, like a banana or vegetables that have been cooked) tekemaot skin (blong samting we $\mathrm{i}$ isi olsem banana o bredfrut we i dan)

wur sweep brum

wurveg $_{1}$ clear, clean, prepare for something klinim 


\section{Y Speed, manner and relative time}

YO General

gem (fr.var. gëm) $\mathbf{1} \cdot$ just $\sim$ nomo $\mathbf{2}$ • only, just nomo

kara just, of an event that has happened very recently or will happen very shortly after an upcoming event $\sim$ jas

manene reason $\sim$ risen

sisia different $\sim$ defren

\section{Y1 Speed and manner}

gamlöt $\mathbf{1} \cdot$ quickly hariap, kwiktaem

$2 \cdot$ be quick, hurry up go hariap

gem (fr.var. gëm) $\mathbf{1} \cdot$ just $~$ nomo $\mathbf{2}$ • only, just nomo

kara just, of an event that has happened very recently or will happen very shortly after an upcoming event $\sim$ jas

lelev fast, be fast $\sim$ hariap

manene reason $\sim$ risen

mav 1 - heavy hevi, no laet 2 • difficult, hard, not easy had, no isi meneg $1 \cdot$ hard, be hard strong, olsem i no sofsof $\mathbf{2}$ - be strong, powerful strong, olsem i gat paoa 3 - intense $\sim$ strong, olsem i gat paoa blong hem $\mathbf{4} \cdot$ be determined strong, olsem fasin i strong

mölumlum $\mathbf{1} \cdot$ soft $\sim$ sofsof $\mathbf{2} \cdot$ slow, slowly slo, sloslo

möul 1 - for a long time, take a long time $\sim$ tekem longtaem $2 \cdot$ slow, be slow sloslo

sisia different $\sim$ defren

tenēnēg 1 - straight, not bent or curved stret, no kruked $\mathbf{2} \cdot$ correct, right, correctly $\sim$ stret, gud

valakreg randomly, not in ordered way olbaot

wareg $1 \cdot$ well, completely, totally gud $\mathbf{2} \cdot$ properly $\sim$ stret

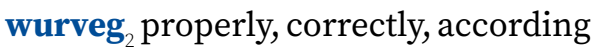
to one's aim or desire stret, gud

Y2 Relative time and duration

garqe $\mathbf{1} \cdot$ today $\sim$ tede $\mathbf{2} \cdot$ later on today, today in the afternoon or evening; earlier today, earlier the same day tede long aftenun, tede long moning finis $3 \cdot$ at the present time or age; these days $\sim$ long taem tede

la masawre when, introduces temporal adverbial clause $\sim$ taem

$\mathbf{l a v}_{1}$ forever, without ceasing oltaem, wantaem

möul 1 - for a long time, take a long time $\sim$ tekem longtaem $\mathbf{2} \cdot$ slow, be slow sloslo

orēs time period in the near future, after tomorrow afta tumoro

tastas always $\sim$ evri taem

tōlōw tomorrow $\sim$ tumoro

vaga $1 \cdot$ always, all the time $\sim$ oltaem, evritaem $\mathbf{2}$ often, regularly $\sim$ fulap taem

$\operatorname{van}_{1} \mathbf{1} \cdot$ go (unmarked for direction) go $\mathbf{2}$ - on and on, postverbal particle indicating continuous aspect, continuation of an activity $\sim$ go go

vatiwial $\mathbf{1} \cdot$ once $\sim$ wantaem $\mathbf{2}$ - at once, straight away wantaem

vèti (fr.var. viti) still yet

\section{Y3 Serialisation}

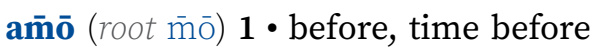
now $\sim$ bifo, fastaem $\mathbf{2}$ - first, in front $\sim$ fastaem

basbasne last laswan

bilēñ (fr.var. bilēn) $\mathbf{1} \cdot$ again, modifies verb in the verb complex $\sim$ bakegen $2 \cdot$ as well, too, modifies noun in the noun phrase $\sim$ tu $3 \cdot$ more, other, another, modifier in the noun phrase moa, bakegen 


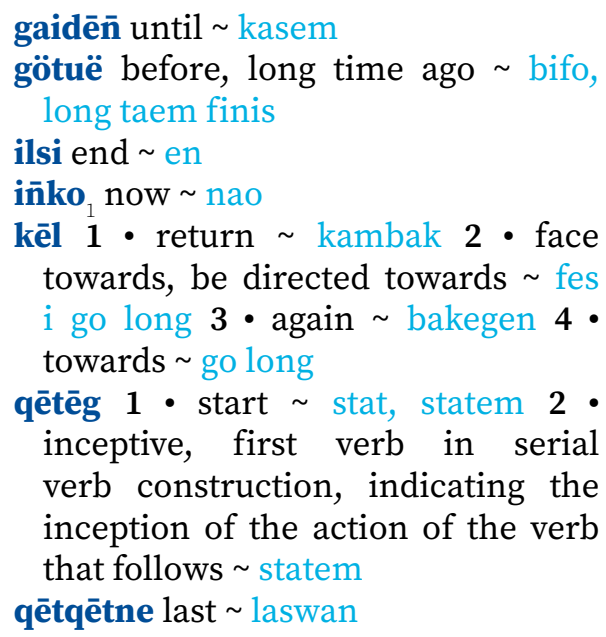

Y4 Degree

döl all evriwan

gem (fr.var. gëm) $\mathbf{1} \cdot$ just $\sim$ nomo $\mathbf{2} \bullet$ only, just $\sim$ nomo

idian very, really, too, too much, degree adverb tumas

kara just, of an event that has happened very recently or will happen very shortly after an upcoming event $\sim$ jas

nimal very, really, too, too much, degree adverb tumas

nötu (fr.var. sönötu; sunötu) $\mathbf{1} \cdot$ small, be small, become small smol

ren emphatic marker; right, absolutely, totally, definitely tumas, tru, stret; $i$ makem strong toktok we yu talemaot

rivteg 1 - near, close by $\sim$ klosap $\mathbf{2} \cdot$ near to, close to $\sim$ klosap long $\mathbf{3} \cdot$ nearly, soon $\sim$ klosap

vilēs all, all over evriwan 
This text is taken from A Dictionary of Vurës, Vanuatu, by Catriona Malau, published 2021 by ANU Press, The Australian National University,

Canberra, Australia.

doi.org/10.22459/DVV.2021.05 